LUCIANA DE ABREU NASCIMENTO

Normas e práticas promovidas pelo Ensino de Ciências por Investigação: a constituição da sala de aula como comunidade de práticas 


\section{LUCIANA DE ABREU NASCIMENTO}

Normas e práticas promovidas pelo Ensino de Ciências por Investigação: a constituição da sala de aula como comunidade de práticas

Tese apresentada à Faculdade de Educação da Universidade de São Paulo para obtenção do título de Doutor em Educação

Área de Concentração: Ensino de Ciências e Matemática

Orientadora: Profa. Dra. Lucia Helena Sasseron 
AUTORIZO A REPRODUÇÃO E DIVULGAÇÃO TOTAL OU PARCIAL DESTE TRABALHO, POR QUALQUER MEIO CONVENCIONAL OU ELETRÔNICO, PARA FINS DE ESTUDO E PESQUISA, DESDE QUE CITADA A FONTE.

Catalogação na Publicação

Serviço de Biblioteca e Documentação

Faculdade de Educação da Universidade de São Paulo

375.2 Nascimento, Luciana de Abreu

N244n Normas e práticas promovidas pelo Ensino de Ciências por Investigação: a constituição da sala de aula como comunidade de práticas / Luciana de Abreu Nascimento; orientação Lucia Helena Sasseron. São Paulo: s.n., 2018.

259 p.; anexos; apêndices; outros

Tese (Doutorado - Programa de Pós-Graduação em Educação. Área de Concentração: Ensino de Ciências e Matemática) - - Faculdade de Educação da Universidade de São Paulo.

1. Ciências (estudo e ensino) 2. Ensino fundamental 3. Prática de ensino 4. Cultura I. Sasseron, Lucia Helena, orient.

Ficha elaborada por Natalina de Jesus Delfina da Luz - Bibliotecária - CRB/8-4018 


\section{FOLHA DE APROVAÇÃO}

NASCIMENTO, L. de A. Normas e práticas promovidas pelo Ensino de Ciências por Investigação: a constituição da sala de aula como comunidade de práticas. Tese apresentada à Faculdade de Educação da Universidade de São Paulo para obtenção do título de Doutor em Educação

Aprovado em:

Banca Examinadora

Prof. Dr. Instituição:

Julgamento: Assinatura:

Prof. Dr. Instituição:

Julgamento: Assinatura:

Prof. Dr. Instituição:

Julgamento: Assinatura:

Prof. Dr. Instituição:

Julgamento: Assinatura:

Prof. Dr. Instituição: Assinatura: 
A meus pais que permitiram que essa jornada começasse.

A meu amor, meus irmãos e meus amigos que me apoiaram durante o percurso.

Àqueles que seguem caminhando comigo. 


\section{AGRADECIMENTOS}

Agradeço a todos aqueles que, ao longo desses anos de pesquisa, estiveram por perto apoiando, questionando, opinando, debatendo, celebrando, consolando, enfim, contribuindo para realização desta tese. Em especial...

agradeço à professora Lúcia por ter acreditado em meu projeto e me acolhido como sua orientanda. Mais ainda, agradeço por ter me ajudado a transformar algumas ideias iniciais em um trabalho do qual me orgulho, por ter me ajudado a crescer como professora e como pesquisadora e por ter me dado a honra de integrar seu grupo de "pupilos".

agradeço às professoras Daniela Scarpa e Danusa Munford que tão gentilmente leram os primeiros esboços desta pesquisa e trouxeram suas contribuições durante o exame de qualificação. Agradeço, também, por terem aceitado se aproximar, novamente, de minhas ideias, na certeza de que poderão contribuir, uma vez mais, para o debate proposto.

agradeço aos professores que compõem a Banca Examinadora por terem aceitado ler, avaliar e participar do processo de construção deste trabalho.

agradeço à professora e à turma do $3^{\circ}$ ano da EMEF na qual essa pesquisa foi realizada e que, passados seis anos, ainda nos permitem conhecer as normas e práticas da sala de aula e pensar o ensino de ciências.

agradeço aos funcionários da FEUSP, em especial aos da Secretaria de Pós-graduação, por sempre estarem dispostos a ajudar.

agradeço ao IFSULDEMINAS por ter me concedido afastamento integral para qualificação, sem o qual a conclusão desta tese parecia ser impossível. Aproveito para agradecer, também, aos estudantes das Licenciaturas em Geografia e em Ciências Biológicas, sempre carinhosos e ansiosos pela minha volta.

agradeço a Deus pela força para superação de cada uma das etapas vividas nesses anos de estudo e pesquisa.

agradeço ao André por ter aguentado os momentos de mau-humor, por ter segurado a barra nas crises, por ter me levado e trazido para os eventos (e por ter ficado lá participando de 
minhas apresentações), por ter ouvido as hipóteses e conversas travadas comigo mesmo e por ter me esperado.

agradeço à minha família, mas principalmente, à minha mãe que me mostrou o amor pela educação e a grandeza de ser professora e à Carol que me acolheu nas idas para São Paulo e fez com que os momentos de lazer fossem regados a pipoca e seriados.

agradeço, por fim, aos amigos do LaPEF que, a cada reunião, mostraram interesse em minha pesquisa, que ajudaram nas leituras e disciplinas, que dividiram uma xícara de café ou um copo de cerveja, que sofreram e que curtiram juntos. 


\section{RESUMO}

NASCIMENTO, L. de A. Normas e práticas promovidas pelo Ensino de Ciências por Investigação: a constituição da sala de aula como comunidade de práticas. 2018. 259 f. Tese (Doutorado) Faculdade de Educação, Universidade de São Paulo, São Paulo, 2018.

Nesta pesquisa buscamos investigar e caracterizar normas e práticas culturais produzidas em aulas de Ciências organizadas pelo Ensino de Ciências por Investigação. Metodologicamente, o trabalho foi estruturado em duas etapas. Na primeira dessas, de cunho teórico, trazemos a articulação de referenciais que debatem o conceito de cultura; a discussão sobre cultura científica e sobre as normas sociais que organizam o processo de construção de conhecimento nas comunidades cientificas; e algumas implicações dessa discussão para o ensino de ciências. Dos estudos sobre cultura, aproximamo-nos de autores que trazem contribuições para pensá-la como maneiras de fazer socialmente construídas a partir dos repertórios disponíveis a um grupo, como práticas que se revestem de sentido nas ações cotidianas de sujeitos que lidam com as normas e empregam de forma criativa aquilo que recebem. Para pensar essas práticas no contexto do ensino de ciências, apresentamos algumas proposições sobre o ensino de ciências como prática que defendem que a disciplina de Ciências se organize em torno de dimensões conceituais, sociais, epistêmicas e materiais do trabalho científico, a fim de criar oportunidades para que os estudantes reconstruam e aprofundem suas ideias e explicações sobre o mundo natural, enquanto se engajam em processos simplificados de trabalho científico. Como uma possibilidade de promoção das quatro dimensões do trabalho científico em sala de aula, apontamos o Ensino de Ciências por Investigação que, em suas diferentes abordagens, preconiza que as atividades promovidas em sala de aula aproximem os estudantes de práticas investigativas. Na etapa empírica desta tese, apresentamos a análise qualitativa de três aulas de ciências que compõem a Sequência de Ensino Investigativa "Navegação e Meio Ambiente", adotando como fontes de dados seu planejamento e o registro audiovisual de sua implementação em um $3^{\circ}$ ano do Ensino Fundamental de uma escola pública paulistana. Nessas aulas, buscamos evidências de quais normas culturais estavam vigentes e organizavam o processo de construção e apreciação de explicações para os problemas propostos nas atividades da sequência. Já para discussão das práticas, buscamos descrever operações realizadas pela professora e pelos estudantes que nos indicavam como, naquela sala, eram produzidas e partilhadas práticas similares às desenvolvidas pelos membros de comunidades científicas no processo de construção de conhecimento. Como resultado desta pesquisa, destacamos que no planejamento da sequência analisada existem orientações que abrangem as quatro dimensões propostas para o ensino de ciências como prática e que essas aparecem com maior ou menor enfoque, conforme os objetivos, procedimentos e exercícios de cada atividade. Destacamos, também, a identificação de uma relação entre a vigência de normas que garantem um processo de criticidade durante o enfrentamento dos problemas propostos e a experiência de práticas ligadas ao processo não só de comunicação, mas de avaliação e validação de explicações. Percebemos, ainda, que à medida em que os estudantes e sua professora se engajaram nas atividades, negociaram sentidos para os problemas propostos e adotaram o repertório disponibilizado pela sequência, puderam se constituir como uma comunidade de práticas.

Palavras-chave: Ensino de Ciências. Ensino Fundamental. Ensino por Investigação. Normas Culturais. Práticas Culturais. 


\begin{abstract}
NASCIMENTO, L. de A. Norms and practices promoted by Inquiry-Based Teaching: the constitution of the classroom as a community of practices. 2018. $259 \mathrm{f}$. Tese (Doutorado) Faculdade de Educação, Universidade de São Paulo, São Paulo, 2018.

In this research we aimed to investigate and characterize cultural norms and practices produced in science classes organized by the Inquiry-Based Teaching. Methodologically, this work was structured in two stages. In the first of these, with a theoretical nature, we bring the articulation of references that debate the concept of culture; the discussion about scientific culture and the social norms that organize the process of knowledge construction in scientific communities; and some implications of this discussion for science teaching. From the studies on culture, we present authors who bring contributions to think about this concept as socially constructed ways of act created from the repertoires available to a group, as practices that are meaningful in the everyday actions of subjects that deal with norms and creatively use what they receive. To think about these practices in the context of science teaching, we present some propositions about science teaching as practice. These propositions advocate that the discipline of science should be organized around the conceptual, social, epistemic and material dimensions of scientific work in order to create opportunities for students to reconstruct and deepen their ideas and explanations of the natural world while engaging in simplified processes of scientific work. As a possibility to promote the four dimensions of scientific work in the classroom, we point to Inquiry-Based Teaching which, in its different approaches, advocates that the activities promoted in the classroom bring students closer to investigative practices. In the empirical stage of this thesis, we present the qualitative analysis of three science activities that compose the Inquiry-Based Teaching Sequence "Navigation and Environment", adopting as data sources its planning and the audiovisual record of its implementation in a 3rd year of Elementary School of a public school in São Paulo. In these classes, we searched for evidence of what cultural norms were in force and organized the process of constructing and appreciating explanations for the problems proposed in the sequence. To discuss the practices, we sought to describe the operations carried out by the teacher and the students that showed us how, in that room, practices similar to those developed by the members of scientific communities in the process of knowledge construction were produced and shared. As a result of this research, we highlight that in the planning of the analyzed sequence there are guidelines that cover the four dimensions proposed for teaching science as practice and that these appear with greater or lesser focus, according to the objectives, procedures and exercises of each activity. We also highlight the identification of a relationship between the validity of norms that guarantee a critical process during the confrontation of the proposed problems and the experience of practices related to the process of not only communication, but also evaluation and validation of explanations. We also realized that as the students and their teacher engaged in the activities, they negotiated meanings for the problems proposed and adopted the repertoire made available by the sequence, they could constitute a community of practices.
\end{abstract}

Keywords: Cultural Norms. Cultural Practices. Elementary School. Inquiry-Based Teaching. Science Teaching 


\section{LISTA DE FIGURAS}

Figura 1 - Atividades integrantes da SEI "Navegação e Meio Ambiente"

Figura 2 - Representação gráfica da sala, conforme registro em vídeo, durante a Aula 1 - a travessia do rio

Figura 3 - Momentos e episódios da Aula 1- A travessia do rio

Figura 4 - Argumentos construídos durante a resolução do problema proposto na Aula 1- A travessia do rio

Figura 5 - Explicação construída durante a resolução do problema proposto na Aula 1- A travessia do rio

Figura 6 - Representação gráfica da sala, conforme registro em vídeo, durante a Aula 5 -

Leitura e discussão de textos

Figura 7 - Momentos e episódios da Aula 5 - Leitura e discussão de textos

Figura 8 - Explicações construídas durante a resolução dos problemas propostos na Aula 5 -

Leitura e discussão de textos

Figura 9 - Representação gráfica da sala, conforme registro em vídeo, durante Aula 8 Análise dos dados da tabela

Figura 10 -Informações presentes na lousa durante a Aula 8 - Análise dos dados da tabela 166

Figura 11 - Momentos e episódios da Aula 8 - Análise dos dados da tabela.....

Figura 12 - Explicação construída durante a resolução dos problemas propostos na Aula 8-

Análise dos dados da tabela

Figura 13 - Modelo construído durante a resolução dos problemas propostos na Aula 8 -

Análise dos dados da tabela 


\section{LISTA DE QUADROS}

Quadro 1 - Proposta de dimensões a serem integradas nos objetivos para o ensino de ciências construída a partir das dimensões com as quais, conforme Stroupe (2015), os novatos entram e contato e aprendem na prática de trabalho nas comunidades científicas

Quadro 2 - Proposta de normas que devem orientar a construção de explicações científicas em sala de aula elaborada a partir das normas para produção do conhecimento científico de Longino (2002)

Quadro 3 - Objetivos gerais para SEI "Navegação e Meio Ambiente" 64

Quadro 4 - Critérios para transcrição das aulas construídos a partir de Preti (2000) 76

Quadro 5 - Modelo de mapa da atividade 77

Quadro 6 - Modelo de mapa de episódio 79

Quadro 7 - Modelo de quadro síntese das normas e práticas presentes na atividade 81

Quadro 8 - Mapa da Atividade 1 - A travessia do rio 83

Quadro 9 - Episódio 1- Atividade 1- A travessia do rio - 17/09/2012 .................................... 86

Quadro 10 - Episódio 2- Atividade 1- A travessia do rio - 17/09/2012 .................................91

Quadro 11 - Episódio 3- Atividade 1- A travessia do rio - 17/09/2012 ….............................. 95

Quadro 12 - Episódio 4- Atividade 1- A travessia do rio - 17/09/2012 _.................................98

Quadro 13 - Episódio 5- Atividade 1- A travessia do rio - 17/09/2012 ................................ 103

Quadro 14 - Episódio 6- Atividade 1- A travessia do rio - 17/09/2012 ................................. 108

Quadro 15 - Episódio 7- Atividade 1- A travessia do rio - 17/09/2012 .................................111

Quadro 16 - Episódio 8- Atividade 1- A travessia do rio - 17/09/2012 ................................ 115

Quadro 17 - Episódio 9- Atividade 1- A travessia do rio - 17/09/2012 ................................ 122

Quadro 18 - Síntese das normas e práticas presentes na Aula 1- A travessia do rio ............. 127

Quadro 19 - Mapa da atividade 6 - Leitura e discussão do texto "Mantendo embarcações na água"

Quadro 20 - Mapa da atividade 7 - Leitura e discussão do texto "Vida marinha na água de lastro" 
Quadro 21 - Episódio 1- Atividade 6- Leitura e discussão do texto "Mantendo embarcações na água" - 29/10/2012

Quadro 22 - Episódio 2- Atividade 6- Leitura e discussão do texto "Mantendo embarcações na água" - 29/10/2012.

Quadro 23 - Episódio 3- Atividade 6- Leitura e discussão do texto "Mantendo embarcações na água" - 29/10/2012.

Quadro 24 - Episódio 1- Atividade 7- Leitura e discussão do texto "Vida marinha na água de lastro" - 29/10/2012

Quadro 25 - Episódio 2- Atividade 7- Leitura e discussão do texto "Vida marinha na água de lastro" - 29/10/2012 154

Quadro 26 - Síntese das normas e práticas presentes na Aula 5 - Leitura e discussão de textos

Quadro 27 - Mapa da atividade 9 "Análise dos dados da tabela"

Quadro 28 - Episódio 2- Atividade 9- Análise dos dados da tabela - 11/11/2012............... 171

Quadro 29 - Episódio 3- Atividade 9- Análise dos dados da tabela - 11/11/2012 ............... 176

Quadro 30 - Episódio 4- Atividade 9- Análise dos dados da tabela - 11/11/2012 ............... 181

Quadro 31 - Episódio 5- Atividade 9- Análise dos dados da tabela - 11/11/2012................ 185

Quadro 32 - Episódio 6- Atividade 9- Análise dos dados da tabela - 11/11/2012 2............... 192

Quadro 33 - Síntese das normas e práticas presentes na Aula 8 - Análise dos dados da tabela

Quadro 34 - Maneiras como as dimensões a serem integradas nos objetivos para o ensino de ciências aparecem nas atividades analisadas

Quadro 35 - Síntese das normas presentas nas aulas analisadas 203

Quadro 36 - Síntese das práticas presentas nas aulas analisadas .206 


\section{LISTA DE SIGLAS}

EMEF - Escola Municipal de Ensino Fundamental

LaPEF - Laboratório de Pesquisa em Ensino de Física da Faculdade de Educação da Universidade de São Paulo

NRC - National Research Council

SEI - Sequência(s) de Ensino Investigativa(s) 


\section{SUMÁRIO}

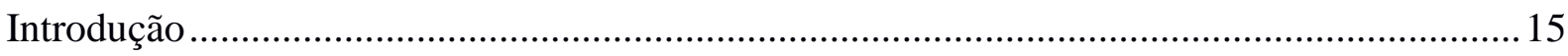

1 A construção das práticas culturais como objeto de pesquisa ................................................. 19

1.1 A cultura como matriz de permutações …………………………………………....... 19

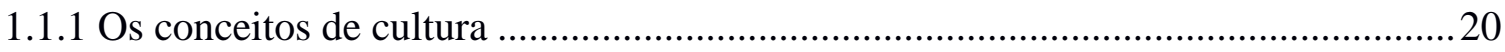

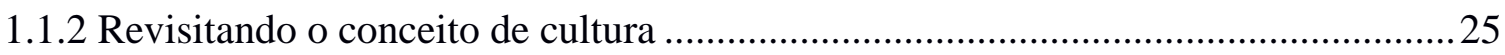

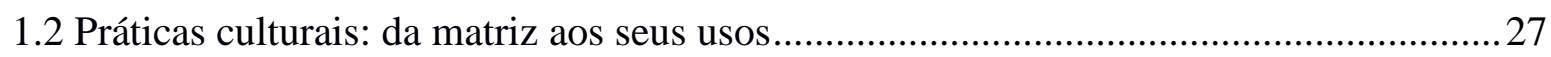

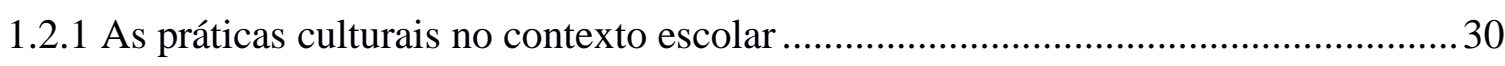

$2 \mathrm{O}$ ensino de ciências como prática: novas finalidades para disciplina de Ciências ...............33

2.1 Normas e práticas das comunidades científicas no contexto escolar: possíveis diálogos

2.1.1 A sala de aula de ciências como comunidade de práticas.............................................43

3 O Ensino de Ciências por Investigação como uma abordagem para o ensino de ciências

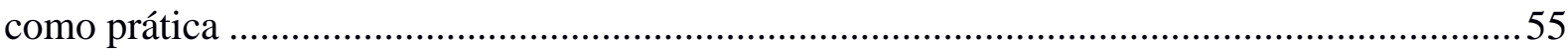

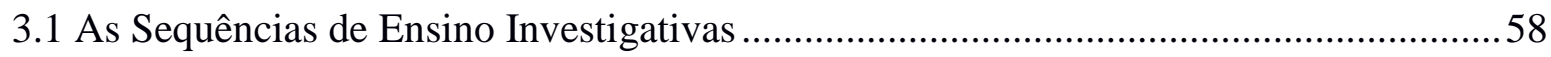

3.1.1 A Sequência didática "Navegação e Meio Ambiente" como prescrição de práticas62 4 Metodologia e contexto de pesquisa...........................................................................

4.1 O caso em estudo: materiais e seu contexto de coleta ................................................... 72

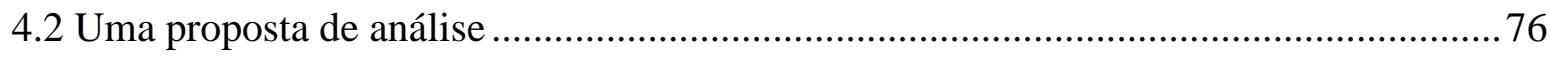

5 Ensino de Ciências por Investigação entre normas e práticas ................................................. 82

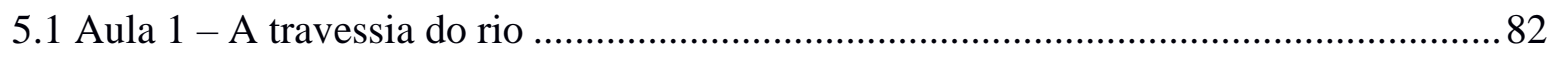

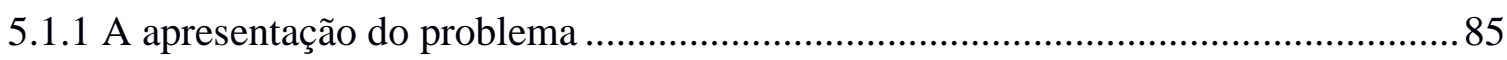

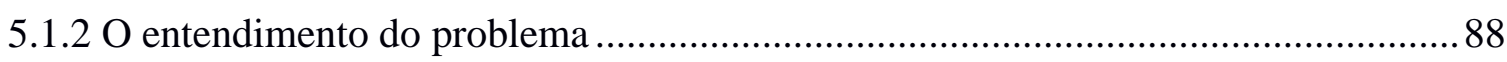

5.1.3 O enfrentamento coletivo do problema.................................................................. 102

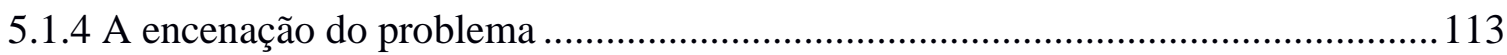

5.1.5 Considerações sobre a atividade "A travessia do rio"............................................126

5.2 Aula 5 - Leitura e discussão de textos........................................................................ 131

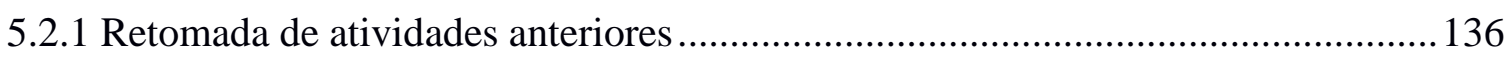

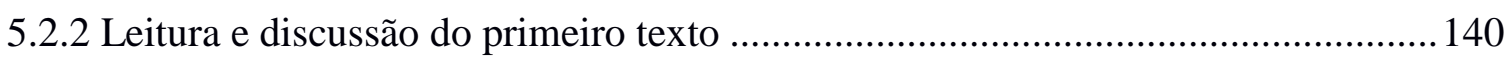

5.2.3 Leitura e discussão do segundo texto .................................................................... 149

5.2.4 Condução de síntese das discussões...................................................................152

5.2.5 Considerações sobre as atividades de leitura e discussão de texto ...........................155 
5.3 Aula 8 - Análise dos dados da tabela 163

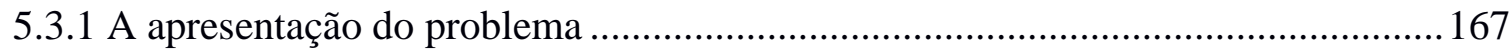

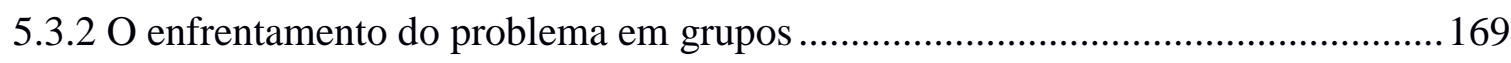

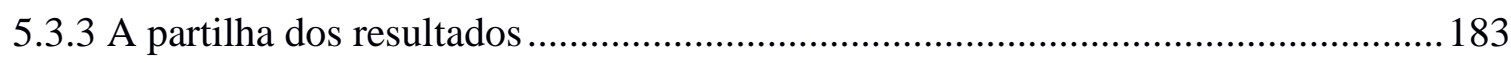

5.3.4 A leitura e discussão do texto "Entendendo o jogo presa e predador" e o registro

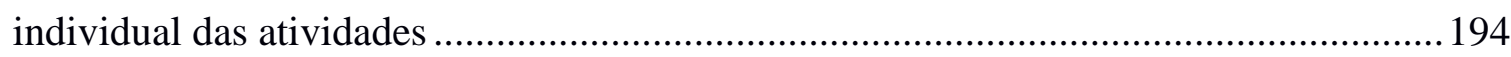

5.3.5 Considerações sobre a atividade "Análise dos dados da tabela" .......................... 195

5.4 Considerações sobre a SEI "Navegação e Meio Ambiente" .......................................200

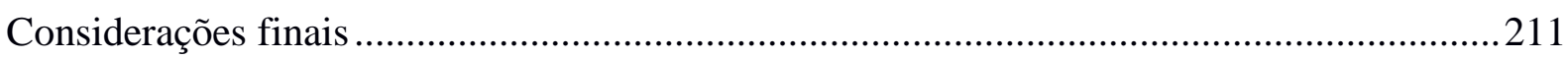

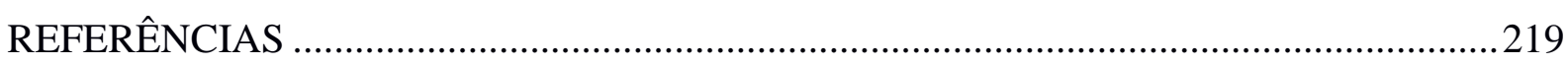

APÊNDICE A -Transcrição da atividade 1 - A travessia do rio - 17/09/2012 - 42’15” de vídeo

APÊNDICE B - Transcrição das atividades 6 e 7 - A questão da água de lastro - 29/10/2012

- 26’27”' de vídeo

APÊNDICE C - Transcrição da atividade 9 - Análise dos dados da tabela- 27/11/2012 45'10" de vídeo

ANEXO A - Orientações para a resolução da atividade "A travessia do rio".

ANEXO B - Texto "Mantendo embarcações na água" para realização da sexta atividade...252

ANEXO C - Imagens para realização da sexta atividade

ANEXO D - Texto "Vida marinha na água de lastro" para realização da sétima atividade..254

ANEXO E - Modelo de tabela para registro e análise do jogo "Presa e predador" para realização da nona atividade

ANEXO F - Questões recebidas pelos estudantes para realização da nona atividade 256

ANEXO G - Texto "Entendendo o jogo presa e predador" para realização da nona atividade 


\section{Introdução}

Em conformidade com as tendências pedagógicas tradicionais que regem as práticas escolares durante a primeira metade do século XX, o ensino de ciências esteve, por um longo período, focado na transmissão de informações (KRASILCHIK, 2000) que os estudantes deveriam memorizar e replicar, restando pouco espaço em sala de aula para problematização, investigação e argumentação, entre outras práticas características das ciências (SANDOVAL, 2005; MUNFORD; LIMA, 2007; DUSCHL, 2008; KELLY, 2014; STROUPE; 2014, 2015).

Contudo, desde meados do século XX, concepções mais modernas sobre educação ganham terreno no cenário global e os pesquisadores do campo passam a sinalizar a necessidade de realizar-se alterações significativas nos modelos de ensino vigentes. Essa reformulação teórica dá-se, principalmente, em decorrência de dois grandes fatores que alteram os modos como o processo de escolarização é compreendido:

o primeiro deles foi o aumento exponencial do conhecimento produzido não é mais possível ensinar tudo a todos. Passou-se a privilegiar mais os conhecimentos fundamentais dando atenção ao processo de obtenção desses conhecimentos. Valorizou-se a qualidade do conhecimento a ser ensinado e não mais a quantidade. $\mathrm{O}$ segundo fator foram os trabalhos de epistemólogos e psicólogos que demonstraram como os conhecimentos eram construídos tanto em nível individual quanto social (CARVALHO, 2013, p. 1).

Nesse contexto de mudanças, as concepções e teorias sobre educação passam por uma paulatina ressignificação e, consequentemente, o ensino de ciências deixa de ser visto unicamente como a transmissão de um conjunto de conceitos, fatos ou teorias, passando a ser defendido, entre alguns pesquisadores da área, como um processo que envolve a iniciação dos estudantes nas práticas das comunidades científicas (NAYLOR; KEOGH; DOWNING, 2007), ou seja, nas maneiras como membros das comunidades científicas compreendem o mundo natural e agem sobre esse a fim de construir novas explicações, por meio de um processo de construção, comunicação e análise de proposições. Nessas pesquisas, vemos uma mudança de enfoque, que passa a ser direcionado não somente pelo questionamento sobre o que os estudantes precisam saber para aprender ciências, mas também pela problematização sobre o que esses precisam ser capazes de fazer (DUSCHL, 2008) enquanto aprendizes de um corpo organizado de conhecimentos e de práticas culturais de produção desse.

Entretanto, essa noção de fazer não remete à simples experimentação ou manipulação de materiais a fim de confirmar fatos sustentados pelos livros didáticos ou professores. O fazer, como elemento presente em sala de aula, deve ser parte de um processo 
de aproximação entre os estudantes e as práticas das comunidades científicas, no qual o objetivo do ensino não seja desenvolver um alto nível de perícia nessas práticas, mas sim criar oportunidades para que os estudantes vivenciem processos comumente utilizados por essas comunidades e os compreendam como possibilidades de construção de conhecimento, tornando-se capazes de escolher entre os diferentes processos disponíveis, bem como de justificar suas escolhas (OSBORNE, 2016). Garantindo-se o envolvimento dos estudantes como essas práticas, tem-se a expectativa de não apenas engajá-los na construção de explicações em sala de aulas, mas de proporcionar uma compreensão mais profunda do processo pelo qual o conhecimento é construído nas comunidades científicas (GONZALEZHOWARD; MCNEILL, 2016).

No interior do movimento de revisão do foco e das finalidades do ensino de ciências, abordagens investigativas de ensino passam a ser propostas e defendidas por pesquisadores de países da América do Norte e Europa, remetendo a uma pluralidade de objetivos, procedimentos e exercícios que têm em comum a preocupação de

sugerir imagens alternativas de aulas de ciências, diferentes daquelas que têm sido mais comuns nas escolas, dentre elas, o professor fazendo anotações no quadro, seguidas de explicações e os estudantes anotando e ouvindo-o dissertar sobre um determinado tópico de conteúdo (MUNFORD; LIMA, 2007, p. 92).

Para construção dessas alternativas, "é preciso promover um ensino mais interativo, dialógico e baseado em atividades capazes de persuadir os alunos a admitirem as explicações científicas para além dos discursos autoritários, prescritivos e dogmáticos" (MUNFORD; LIMA, 2007, p. 110). Tendo isso em vista, em diferentes propostas de Ensino de Ciências por Investigação, são levadas para sala de aula atividades que pretendem aproximar os estudantes de práticas investigativas como fazer observações; questionar; buscar dados e informações em fontes variadas; planejar ações; rever ideias à luz de evidências experimentais; usar ferramentas para coletar, analisar e interpretar os dados; propor respostas, explicações e previsões; além de comunicar resultados (FORD, 2015).

No Brasil, as questões relacionadas ao Ensino de Ciências por Investigação também repercutem entre os pesquisadores da área. Partilhando das premissas dessa abordagem de ensino, no Laboratório de Pesquisa em Ensino de Física da Faculdade de Educação da Universidade de São Paulo (LaPEF), foram elaboradas Sequências de Ensino Investigativas (SEI) compostas por atividades investigativas, dentre elas, atividades de conhecimento físico 
planejadas para os anos iniciais do Ensino Fundamental ${ }^{1}$. Nas SEI, para cada uma das atividades elaboradas, são pensados e propostos materiais e interações de modo a criar um ambiente investigativo em salas de aula de ciências e a favorecer, entre os estudantes, o exercício de práticas similares àquelas envolvidas no processo (simplificado) do trabalho científico (CARVALHO, 2013).

Se essa aproximação dos estudantes com as práticas das comunidades científicas for efetivada em sala de aula de modo a garantir que eles saiam da posição de receptores passivos de informações e assumam a posição de agentes epistêmicos, é possível que a sala de aula se configure como uma comunidade de práticas científicas, "um contexto no qual professores e estudantes negociem formas particulares de atividade disciplinar e de conhecimento" (STROUPE, 2014, p. 489). Entretanto, conforme Stroupe (2015), em decorrência das especificidades dos objetivos que norteiam a disciplina de Ciências e a diferenciam do processo de trabalho científico, é necessário que tenhamos sempre em vista que essas comunidades de práticas científicas no contexto escolar distinguem-se qualitativamente daquelas existentes em outros contextos, de modo que se façam necessárias pesquisas futuras que visem a melhor compreender como diferentes abordagens de ensino ou específicas interações discursivas podem contribuir para que um grupo de estudantes e seus professores negociem seus papéis nas comunidades de práticas que se estabelecem em sala de aula.

Considerando essa possibilidade e acreditando que, em virtude de seus objetivos gerais, o Ensino de Ciências por Investigação pode promover a constituição dessas comunidades de práticas científicas no contexto escolar, perguntamo-nos que práticas caracterizariam e que normas organizariam o espaço de sala de aula de ciências organizado pelo ensino por investigação. Todavia, tendo em vista "que as práticas escolares constituemse como práticas culturais. Ou seja, apresentam modos de estar no mundo, de compreender a realidade e de estabelecer sentido, partilhados social e historicamente" (VIDAL, 2006, p. 158), complementamos essa indagação inicial e definimos como nosso problema de pesquisa a seguinte questão: quais normas e práticas culturais são produzidas no espaço de sala de aula de ciências organizado pelo ensino por investigação?

A partir dessa pergunta, definimos algumas questões intermediárias que guiam a construção deste trabalho e ajudam-nos a construir elementos para responder ao nosso

\footnotetext{
${ }^{1}$ Neste trabalho, analisaremos uma dessas sequências, contudo, o registro das aulas analisadas, assim como o planejamento e a aplicação da sequência de ensino precedem o início deste trabalho de pesquisa e não foram realizados por nós. A apresentação da sequência e a descrição de suas atividades e materiais de apoio é feita na terceira seção desta tese, já o detalhamento do procedimento de coleta e construção dos dados são apresentados na quarta seção.
} 
problema inicial: o que é cultura e o que são as normas e a práticas culturais? Como normas e práticas culturais estão presentes e podem ser analisadas no contexto de sala de aula? No planejamento de atividades investigativas são pensadas situações que oportunizem a produção de normas e práticas em sala de aula?

Para responder a essas perguntas, realizamos um estudo de caso que teve como materiais de análise (1) o planejamento da SEI "Navegação e Meio Ambiente" elaborada para o $3^{\circ}$ ano do Ensino Fundamental e (2) os registros audiovisuais das aulas ministradas a partir dessa sequência em uma Escola Municipal de Ensino Fundamental (EMEF) da cidade de São Paulo, durante o ano de 2012. No planejamento da SEI, buscamos elementos que nos permitissem refletir sobre as possibilidades desse material para promoção de uma aproximação dos estudantes com as práticas das comunidades científicas, já na implementação das atividades, como principal foco desta pesquisa, buscamos caracterizar as normas e práticas construídas e partilhadas por um grupo de estudantes e sua professora, durante a realização das atividades propostas.

Ao final deste trabalho, esperamos ter conseguido caracterizar normas e práticas culturais que são produzidas no espaço de sala de aula de ciências organizado pelo ensino por investigação; identificar e discutir relações entre as práticas encontradas e as normas que organizam a participação durante a construção de explicações aos problemas propostos na SEI; bem como refletir sobre as possibilidades de, durante o enfrentamento e resolução das atividades, a sala de aula se constituir como uma comunidade de práticas. 


\section{A construção das práticas culturais como objeto de pesquisa}

Buscar a unificação de significados em torno da noção de cultura é, segundo Bauman (2012), uma operação pouco proveitosa ao pesquisador que pode resultar, inclusive, no empobrecimento do potencial explicativo do termo. Para o autor, a dificuldade, se não impossibilidade, dessa empreitada está tanto na incompatibilidade entre as correntes de pensamento que, sustentadas por premissas e interesses divergentes, empregaram a cultura como unidade de análise ao longo dos séculos, quanto e, principalmente, na ambivalência inerente ao termo que, em uma única palavra, remete à criatividade humana e à regulação normativa que se impõe a essa.

Nesse sentido, para apontar a que nos referimos ao falarmos de cultura, seria improdutivo buscar uma unidade conceitual, uma essência em comum nas aplicações do termo pelas diferentes áreas de conhecimento. Igualmente inapropriado, seria tentar eliminar a pluralidade de significados, por vezes opostos, própria do conceito. Contudo, ainda que assumindo a ineficácia de trabalhar a partir de um consenso, antes de nos aprofundarmos nas discussões sobre as práticas culturais do Ensino de Ciências por Investigação, parece-nos necessário identificar as concepções de cultura das quais nos aproximamos ao adotarmos as práticas culturais como o objeto de pesquisa. Com esse fim, nesta seção faremos uma breve revisão do conceito de cultura (EAGLETON, 2005; WILLIAMS, 2007; BAUMAN, 2012), estabelecendo aproximações entre esse e a ideia de prática (CERTEAU, 1985, 2014).

Esses referenciais serão centrais para análise das práticas culturais que são construídas no espaço de sala de aula organizado pelo Ensino de Ciências por Investigação, orientando esta pesquisa não apenas para as atividades e materiais disponibilizados por uma SEI, mas também para as maneiras como esses são utilizados por um grupo de estudantes e sua professora. Ao final desta seção, esperamos ser possível tornar mais claro a que nos referimos quando mobilizamos a noção de cultura neste trabalho de pesquisa e que possibilidades e caminhos de investigação as práticas culturais, enquanto objeto de pesquisa, nos oferecem.

1.1 A cultura como matriz de permutações 
No início da década de 1970, Bauman empreende o esforço teórico de construir uma revisão crítica sobre os usos do conceito de cultura nas Ciências Sociais e Humanas. Com a publicação de Ensaios sobre o conceito de cultura, em 1973, o autor desembaralha algumas noções de cultura presentes no discurso científico, apontando possibilidades e riscos dos estudos sobre a cultura e seus significados sociais. Organizado em três grandes eixos, o livro traz a cultura como conceito, como estrutura e como práxis, caracterizando cada um desses usos, suas bases e implicações.

Com a segunda edição do livro em 1999, essa caracterização é revista e ampliada pelo autor em uma longa introdução crítica na qual, entre outros, temos o questionamento quanto à pertinência do esforço por ele mesmo empreendido de, ao definir cultura como conceito, identificar e separar os principais contextos discursivos que se abrigam sob o termo. Procedimento que, à época da primeira edição, fora motivado pela crença de que seria possível e eficiente desfazer e evitar as ambivalências abrigadas nos correntes conceitos de cultura, mas que, em um segundo momento, é repensado por Bauman (2012, p. 18) que afirma não considerar mais

que a eliminação de tal ambivalência, se ela for ao menos concebível, seria uma coisa boa, reforçando, por assim dizer, a utilidade cognitiva do termo. [...] Creio, pelo contrário, que a ambivalência inerente à ideia de cultura, a qual refletia fielmente a ambiguidade da condição histórica que ela pretendia captar e descrever, era o que tornava essa ideia um instrumento de percepção e reflexão tão proveitoso e persistente.

Partilhando dessa ideia, a fim de preservar a capacidade explicativa do termo, partimos para discussão sobre a cultura como conceito, buscando compreender os significados que ela engendra sem, contudo, tentar desmembrá-los.

\subsubsection{Os conceitos de cultura}

Observando os usos feitos por antropólogos e sociólogos em diferentes situações de observação e frente a distintos objetos pesquisa, Bauman (2012) pontua que a cultura, em decorrência desses diversos contextos de uso e de seus significados pré-científicos, conformase não como um conceito que comporta diferentes definições, mas como um termo que encerra em si conceitos teóricos diversos. Exemplificando esses conceitos, o autor identifica que, no decurso da história, o termo cultura foi incorporado a três universos de discurso e, em 
cada um desses, organiza um campo semântico diverso e sugere diferentes conjuntos de questões e estratégias de pesquisa (BAUMAN, 2012).

Como primeiro desses campos semânticos identificados pelo autor, temos o que confere à cultura um conceito hierárquico. Ainda hoje recorrente em nossa linguagem cotidiana, essa primeira noção remete a um nível de refinamento a ser atingido por um sujeito dentro dos padrões de dado grupo social a fim de se tornar uma pessoa culta, alguém que possui cultura. Constituindo essa noção, temos a premissa da cultura como propriedade individual herdada ou adquirida, podendo ser transformada, adaptada, ou mesmo, abandonada. Opção última que relegaria ao sujeito a posição de inculto.

Esse conceito de cultura como cultivo remonta à história não-científica da palavra no interior da língua inglesa. Conforme mostra Williams (2007), no início do século XV, em suas primeiras aparições dentro do idioma, o termo referia-se, primordialmente, ao cultivo do campo, sendo o processo de cuidado com a colheita e animais. No decorrer do século XVII, esse sentido é ampliado, à medida que autores como Francis Bacon e Thomas Hobbes passam a falar em cultura das mentes, estendendo o significado do cuidado com o crescimento natural, para o processo de desenvolvimento humano. Processo esse que trazia implícita a aposta no desvelar de um potencial inato do indivíduo como forma de alcançar o máximo de sua virtude.

Para Bauman (2012), nesse universo discursivo, a cultura assume um tom de plenitude, estando marcada pela moral, o bom e o belo em um movimento de superação da barbárie, de modo que ainda não seja concebível o uso de culturas no plural, sendo aceita, apenas, uma única cultura ideal, genuína, expressão do ápice do desenvolvimento da potencialidade humana.

Em aplicações em pesquisa que buscam discutir temas relacionados à cultura científica e à cultura escolar encontramos algumas ideias que remetem ao conceito hierárquico, a seu uso como arquétipo a partir do qual, como explica Bauman (2012, p. 90),

nós reprovamos uma pessoa que não tenha conseguido corresponder aos padrões do grupo pela 'falta de cultura'. Enfatizamos repetidas vezes a 'transmissão da cultura' como principal função das instituições educacionais. Tendemos a classificar aqueles com quem travamos contato segundo seu nível de cultura.

A presença desse sentido se evidencia, como mostram Díaz e García (2011) em meados do século XX no contexto ibero-americano, em trabalhos que pensavam a cultura científica de forma enciclopédica, definindo-a como um corpo fechado de informações e medindo-a pelo grau de conhecimento dos feitos científicos a fim de descobrir e comparar a 
aderência de conteúdos da educação formal e a compreensão pública das ciências entre indivíduos, grupos e sociedades. Nessa noção hierárquica da cultura científica, a compreensão de feitos e métodos científicos definiria o sujeito culto e, portanto, hábil a participar em sociedade. Visão também encontrada por Costa, Conceição e Ávila (2007) nas décadas de 1950 e 1960 na Europa e Estados Unidos da América.

Já nos estudos sobre a cultura escolar, identificamos o conceito hierárquico de forma mais representativa em trabalhos que, nos anos 1990, buscavam compará-la com a cultura das classes populares, destacando a incompatibilidade entre essas duas culturas como causa do fracasso, ou mesmo, da evasão escolar (ARROYO, 1992; PATTO, 1994). Nessa visão, a cultura vivida na escola é tida como o ideal de valores e conhecimentos, como meta desejável de comportamentos e saberes que deveriam ser veiculados para construção de uma identidade nacional.

Retomando a apresentação dos conceitos de cultura, como segundo significado identificado por Bauman (2012), para além do desenvolvimento individual, temos a cultura como conceito diferencial. Esse conceito, explicativo das particularidades visíveis entre comunidades humanas, está sustentado na premissa de que o ser humano não é biologicamente determinado e, mais do que isso, de que o aparato orgânico é insuficiente para explicar a humanidade.

$\mathrm{Na}$ cultura como conceito diferencial, parece-nos emergir a complexa relação que, historicamente, estabeleceu-se entre os termos cultura e civilização. Como explica Eagleton (2005, p. 20), por vezes tomados como sinônimos, ao remeter à ideia de cultura "a palavra ‘civilização' é em parte descritiva e em parte normativa: ela pode tanto designar neutramente uma forma de vida ('civilização inca') como recomendar implicitamente uma forma de vida por sua humanidade, esclarecimento e refinamento".

Segundo Williams (2007), em decorrência dessa natureza descritiva e normativa, os primeiros encontros com civilizações desconhecidas resultaram em caracterizações que traziam a marca da comparação com um modelo pretensamente genuíno, do olhar curioso sobre o modo de viver do outro, sem conferir-lhe o status de cultura, de modo que falar de culturas como modos de vida característicos, só passa a ser possível nos anos finais do século XVIII, quando novos interpretações sobre as relações humanas resulta em um gradual abandono da premissa de uma cultura ideal a ser alcançada.

Nesse período, com raízes no idealismo alemão e no anticolonialismo, teria sido proposta a insuficiência de explicações calcadas na pretensa superioridade de uma cultura, sendo necessário falar de "culturas específicas e variáveis de diferentes nações e períodos, 
mas também culturas específicas e variáveis dos grupos sociais e econômicos no interior de uma nação" (WILLIAMS, 2007, p. 120).

Nas pesquisas sobre educação e ensino de ciências, o universo discursivo em que "o termo cultura é empregado para explicar diferenças visíveis entre comunidades de pessoas (temporária, ecológica ou socialmente discriminadas)" (BAUMAN, 2012, p. 103), repercute em propostas como de Ferri (2012, p. 24), em que a ciências são tidas como

uma espécie de instituição social, bem como seu conjunto de crenças sobre o mundo; crenças que seriam fruto das práticas baseadas na aplicação de um procedimento ou método específico, o científico. [...] A cultura não se opõe à incultura, mas, de modo geral, à natureza e, de modo específico, às crenças e práticas de outros grupos humanos; o que não implica que seus produtos e atividades estejam dotados de um carisma ou de uma aura de especial singularidade ou admiração.

De forma similar, nos estudos sobre a cultura escolar, o conceito diferencial aparece na recorrente citação de Julia (2001, p. 10) em que o autor, de forma bastante abrangente, distingue essa cultura como sendo "um conjunto de normas que definem conhecimentos a ensinar e condutas a inculcar, e um conjunto de práticas que permitem a transmissão desses conhecimentos e a incorporação desses comportamentos”. Essas normas e práticas específicas da cultura escolar a diferenciam dos modos de fazer de outras instituições.

Seguindo com a distinção dos universos discursivos abarcados pela cultura, quase como a face oposta às particularidades grupais, Bauman (2012, p. 133) identifica o conceito genérico que tenta dar conta daquilo que é comum ao humano, sua essência, a fronteira homem-natureza: "em sua forma mais simples, o conceito genérico de cultura consiste em atribuir à própria cultura a qualidade de característica universal de todos os homens, e apenas destes". Nesse modelo, uma das possibilidades de definição da natureza humana está na descrição dos elementos singulares à espécie, seja sua consciência, seus valores ou sua habilidade de normatizar e regular o mundo, de modo que as culturas específicas seriam compreendidas como variações desses.

Outra possível vertente de construção de um conceito genérico sustenta-se no modelo estrutural-funcionalista. A definição do próprio humano poderia ser encontrada ao elencarmos, a despeito das particularidades comunitárias, o mínimo necessário para manutenção funcional de todo sistema social, o que compreende desde a supressão do desejo em nome de um bem comum, até as instituições criadas pelo homem. Desse modelo resultam definições coerentes, mas que trazem limitações enquanto ferramenta de análise, uma vez que, implicitamente, adotam como referencial as sociedades organizadas sob as fronteiras do Estado-nação, atendendo aos anseios analíticos das Ciências Sociais, mas sustentando-se no 
pressuposto dos sistemas culturais como dado da natureza humana. Nas palavras de Bauman (2012, p. 138),

o aspecto importante é que esse tipo de generalidade na cultura é um subproduto, quando não um artefato, da não união da humanidade em um todo; de ela estar, pelo contrário, dividida em unidades distintas que devem, em primeiro lugar, ajustar-se à vizinhança de outros grupos humanos e evitar misturar-se com eles, perdendo assim sua própria identidade grupal.

Seguindo na revisão teórica de autores e correntes que tentaram identificar um arcabouço para cultura no sentido genérico, Bauman (2012) identifica a mais fértil resposta em um dos objetos de estudo da psicologia humana: a linguagem, a capacidade humana de criar símbolos arbitrários, de partilhar seus significados no âmbito coletivo e de tomá-los como matéria do pensamento. Não é, portanto, unicamente a capacidade de introduzir intermediários simbólicos, mas a de combiná-los livremente e, nesse processo, estabelecer relações entre referentes (coisas, indivíduos, ideias), reproduzindo e produzindo estruturas. Para o autor, a constante atividade de transformação de si e do mundo é o que define o modo de existência humana. Temos aqui, delineada a ambivalência de uma linguagem que, ao mesmo tempo em que estrutura (permanência), torna-nos a única espécie capaz de impor ao mundo novas estruturas (criação).

$\mathrm{Na}$ literatura essa noção se faz ver, por exemplo, ao falarmos da cultura científica como "conjunto de ferramentas para comunicação e ação prática que as pessoas podem empregar como consequência de seu conhecimento dos conteúdos e procedimentos das ciências (naturais, exatas e sociais)" (LEÓN; COLÓN; ALVARADO, 2013, p. 200). Cultura científica como significados, expectativas e comportamentos compartilhados que não se constitui por um conjunto de conteúdos, mas nas ferramentas culturais utilizadas para estabelecê-los, sendo, entre outros, as formas de se pensar, compreender, avaliar, produzir e comunicar.

De forma similar, em sua forma genérica, a cultura escolar não remonta aos conteúdos específicos que circulam em sala de aula, mas à linguagem e formas de interação que se constroem e são compartilhadas nesse espaço, como podemos perceber nas palavras de Frago (2000, p. 100) ao definir a cultura escolar como "modos de fazer e de pensar mentalidades, atitudes, rituais, mitos, discursos, ações - amplamente compartilhados, assumidos, não postos em questão e interiorizados, servem a uns e a outros para desempenhar suas tarefas diárias, entender o mundo acadêmico-educativo".

Apresentados esses três universos discursivos, passamos para revisão do conceito de cultura e ampliação dessa discussão pela inclusão da ideia de cultura como matriz, que nos 
ajudará a compreender o marco teórico do ensino de ciências como prática e a desenhar os caminhos de investigação, uma vez que tomamos as práticas culturais como objeto desta pesquisa.

\subsubsection{Revisitando o conceito de cultura}

No processo de revisão de seus ensaios sobre o conceito de cultura, Bauman (2012) pondera que, mais do que desconstruir as ideias até então defendidas, percebe a necessidade de acrescentar alguns tópicos e de remanejar as ênfases dadas a determinadas noções. Para nós, um dos pontos centrais e mais caros nessa autocrítica está no destaque da ambivalência como algo inerente ao conceito de cultura e que "reflete a ambiguidade da ideia de construção da ordem, esse ponto focal de toda a existência moderna. A ordem construída pelo homem é inimaginável sem a liberdade humana de escolher" (BAUMAN, 2012, p. 18), de modo que ordenar pressupõe tanto a liberdade de escolha, uma vez que se projetam as probabilidades almejadas, quanto a limitação ou mesmo supressão da escolha, já que é necessário guardar obediência ao projetado.

Para compreender essa proposição, é necessário retornar à segunda metade do século XVIII quando o termo cultura, no início de sua história científica, fora empregado a fim de distinguir as possibilidades de ação criativa humana e os limites impostos pela natureza, definindo-se como a liberdade de transformação do mundo frente à obediência aos fatos naturais (EAGLETON, 2005). Como liberdade, remetendo às possibilidades de ação criativa humana, a cultura é vista como capacidade de resistir à norma. Sentido que Williams (2007) identifica como o mais difundido em nossa linguagem cotidiana, em que a cultura é tomada, por exemplo, como sinônimo de expressões artísticas.

No outro polo, remetendo aos limites impostos, a cultura é instrumento de manutenção, rotina e ordem social. Discurso triunfante nas Ciências Sociais por mais de um século e que toma forma na antropologia ortodoxa que conceitua a cultura como regularidade e padrão imposto, contra o qual se configura a anormalidade e o desvio. Nesse contexto semântico,

cultura era um agregado ou, melhor ainda, um sistema coerente de pressões apoiadas por sanções, valores e normas interiorizados, e hábitos que asseguravam a repetitividade (e portanto a previsibilidade) da conduta no 
plano individual e a monotonia da reprodução da continuidade no decorrer do tempo, da 'preservação da tradição' (BAUMAN, 2012, p.23).

Como uma das grandes expressões desse discurso, Parsons (1982) afirma que a manutenção de um sistema social só seria possível pela existência de um conjunto de valores, crenças, ideias, normas, símbolos e preceitos comungado por sujeitos e que garantisse o ajuste entre esses e o sistema. Esse conjunto, se aceito e internalizado, passaria a constituir a personalidade dos indivíduos e, ao delimitar um padrão de comportamentos, tornaria algumas ocorrências impossíveis ou, ao menos, bastante raras, o que nos permitiria, inclusive, prever os percursos futuros de cada sistema.

Dentro dessa lógica, opera-se com a ideia de dependência entre os elementos de um grupo, de modo que qualquer alteração de estado sofrida por um desses acarrete em um desequilíbrio do todo, sendo necessário que as possibilidades de variação de cada item não extrapolem um limite, de modo que o sistema seja capaz de manter sua identidade. Decorre dessa condição, uma tendência dos itens à conservação, uma vez que a transgressão resultaria na desintegração do sistema. Para manutenção do sistema, é também necessário que esse tenha fronteiras claras, de modo que se possa distinguir o que está dentro ou fora dele e controlar o acesso de novos elementos de forma criteriosa.

Esse modelo de análise, para Bauman (2012, p.31), pode até ter sido eficaz na era de solidificação das identidades nacionais e da submissão de populações nativas por seus colonizadores, mas perde muito de seu significado

com nossa experiência atual de símbolos culturais que flutuam livremente; da porosidade das fronteiras que algumas pessoas gostariam de fechar, embora não sejam capazes; e de governos de Estado que promovem o "multiculturalismo", não mais interessados em privilegiar algum modelo particular de cultura nacional, mas preocupados em não infringir qualquer das incontáveis "opções culturais" individual ou coletivamente assumidas.

Nessa nova lógica, no lugar de tentar caracterizar a cultura como um rígido e estável código de preceitos comportamentais, Bauman (2012) defende que poderíamos vê-la como uma estrutura de escolhas que não serve à reprodução ou à uniformidade, mas à transformação, como "uma matriz de permutações possíveis, finitas em escolhas, mas incontáveis na prática” (BAUMAN, 2012, p. 40).

Para compreender essa ideia, buscamos a linguagem matemática na qual uma matriz de permutação é aquela que tem o efeito de gerar uma permutação dos elementos de um vetor ou entre linhas ou colunas de outra matriz. Nessa operação, os elementos da matriz se rearranjam dando forma a uma nova combinação. Em um paralelo com a linguagem matemática, podemos falar que a cultura, como uma matriz de permutações, se aplica sobre os 
elementos disponíveis aos sujeitos em determinado contexto social, rearranjando-os de incontáveis formas e dando forma a novas maneiras de compreender e agir sobre a realidade, novas práticas culturais.

Para Cardoso Rodrigues (2015, p. 41) essa ideia está sustentada na crença de que a estrutura cultural, a raiz da cultura se modifica, não é estanque, de modo que

dominar uma cultura significa dominar uma matriz de permutações possíveis, um conjunto jamais implementado de modo definitivo, sempre inconcluso, e não uma coletânea finita de significações e a arte de reconhecer seus portadores. O que une os fenômenos culturais a uma cultura é justamente a presença dessa matriz que está em constante mudança, ou seja, que não é estática, mas aberta a mudanças e desenvolvimentos, agregações.

Dentre as proposições teóricas sobre o ensino de ciências, podemos encontrar indícios dessa noção de cultura na corrente discussão sobre as implicações de pensarmos no ensino de ciências como prática. Esse ponto será mais bem desenvolvido na segunda seção desta tese, mas por ora cabe destacar que, segundo Ford (2015, p. 1043),

o ponto básico é que a "prática" nega a possibilidade de articularmos regularidades no raciocínio e na ação que sejam suficientes como instruções para os estudantes. Uma premissa por trás da noção de "prática" é que isso não pode ser feito. As práticas apresentam regularidades e é tentador explicá-las em termos de regras descritivas e prescritivas - o que fazer, como fazer e quando. [...] Isso nos leva à base do que os estudantes precisam aprender: a prática da ciência não se baseia em regras, mas em processos de avaliação e crítica perpétuos que sustentam o progresso nas explicações da natureza. As regularidades são produzidas nesses processos. Em resposta à crítica elas estão em constante mutação.

Nessa proposição, temos a ambivalência entre regularidade e mudança que constitui a noção de cultura como matriz e é em decorrência desse caráter de contínua produção, que, na seção que segue, associamos essa noção à definição de Certeau (1995) de que toda cultura requer uma atividade, uma adoção e uma transformação pessoal instaurada em um grupo social. Esse (re)emprego por parte dos praticantes não se dá de forma aleatória, mas regido por uma lógica interna de modo que, “como na literatura se podem evidenciar 'estilos' ou maneiras de escrever, também se podem distinguir 'maneiras de fazer' - de caminhar, ler, produzir, falar etc." (CERTEAU, 2014, p. 87), maneiras de compreender e de agir negociadas e partilhadas por um grupo, práticas culturais produzidas coletivamente.

1.2 Práticas culturais: da matriz aos seus usos 
Em sua apresentação à segunda edição do livro A invenção do cotidiano: 1. Artes de fazer, Giard (2014, p.12).) reconhece a questão "como se criar?" como sendo a grande inversão de perspectiva teórica proposta por Certeau: deslocar "a atenção do consumo supostamente passivo dos produtos recebidos para a criação anônima, nascida na prática do desvio no uso desses produtos". De modo similar, Maigret (2000) identifica que a principal contribuição daquele autor está em permitir uma nova perspectiva analítica sobre o social ao afastar-se de explicações centradas em grandes estruturas e inserir o conceito de tática como possibilidade de debate acerca da lógica da ação cotidiana.

O cerne teórico dessa questão está em compreender as práticas culturais não, apenas, pelos produtos disponíveis aos sujeitos em determinados circuitos culturais, mas, também, pelas criações cotidianas de sujeitos anônimos a partir daquilo que recebem (CERTEAU, 2014) e das quais nos aproximamos a partir da ideia de cultura como matriz de permutações, uma vez que assumindo a lógica de sistemas (crença de que uma ordem dogmática se impõe sobre os sujeitos de forma autoritária e imobilizante), não conseguiríamos vislumbrar a inventividade dessas criações cotidianas.

Antes de seguir com a discussão sobre as práticas culturais cabe ressaltar que o estudo dessas, ainda que trate das criações de sujeitos anônimos, não implica a adesão ao atomismo social que supunha os indivíduos como unidades elementares da sociedade, sendo essa nada mais que a justaposição daqueles. Nas palavras de Certeau (2014, p. 37), "a questão tratada se refere a modos de operação ou esquemas de ação e não diretamente ao sujeito que é o seu autor ou seu veículo". O foco de pesquisa está, portanto, nas redes de operações de praticantes e não nos indivíduos propriamente ditos, sendo a partir destas que poderemos caracterizar as práticas culturais. Para tanto, ao longo desta tese, trabalharemos com dois conceitos centrais definidos a partir das proposições de Certeau: as práticas e as operações.

Para Certeau (2014), as práticas culturais caracterizam-se como as artes de fazer com, as maneiras criativas de utilizar os bens culturais disponíveis, ocorrendo em diversas passagens de sua obra como maneiras de usar, de se servir, de empregar ou de utilizar ritos, representações míticas, elementos linguísticos, provérbios, lendas, hinos, danças tradicionais, cantos, espaços (rua, apartamento, praça, alojamento, lugar de trabalho, edifício), jornais, imagens de TV, entre outros (CERTEAU, 1985, 2014).

No que mais se aproxima de uma conceituação, o autor propõe que 
respeito à prática. E o problema se torna analisar, ou poder analisar, as práticas cotidianas enquanto uma lógica de práticas, como uma rede de operações cuja formalização pode ser analisada (CERTEAU, 1985, p. 5).

Dessas ideias, podemos falar, inicialmente, das práticas como maneiras de fazer construídas a partir daquilo que temos disponível e que se tornam passíveis de análise por meio da formalidade da rede de operações que as constituem, sendo, as operações entendidas como a ativação das práticas.

Complementarmente, seguindo com a construção apresentada na citação anterior, Certeau (1985, p.6) defende que o estudo das práticas está relacionado ao problema do consumo, afirmando que "do lado do consumidor também há uma produção: ele transforma o espaço que lhe é imposto. [...] ele se serve de um léxico imposto para produzir algo que lhe seja próprio. Desse ponto de vista a questão é do consumidor enquanto criador, enquanto produtor ou enquanto praticante".

Ampliando a definição iniciada acima, a partir dessa citação, podemos dizer que as práticas pressupõem um praticante que opera sobre a realidade de acordo com produtos que essa lhe oferece. Mais ainda, podemos compreender que essas operações se caracterizam pela criatividade, sendo uma transformação do praticante sobre aquilo que lhe é oferecido.

Trazendo essa discussão, para os estudos das práticas escolares e assumindo a proposição de Vidal (2006, p. 158) de que as práticas escolares se constituem como práticas culturais e que, como tal, "não são jamais individuais, a despeito de serem ativadas individualmente por cada sujeito", podemos falar das práticas culturais como as maneiras de fazer partilhadas por um grupo e que podem ser ativadas de forma criativa por seus praticantes, por meio de operações culturais.

De modo mais específico, a partir dessa compreensão e considerando o recorte desta pesquisa, neste trabalho utilizaremos a ideia de práticas culturais do Ensino de Ciências por Investigação como as maneiras de fazer produzidas e partilhadas por um grupo de estudantes e sua professora a partir dos bens e mensagens disponibilizados na aula de ciências durante a realização de atividades de ensino investigativas. Já as operações culturais do Ensino de Ciências por Investigação seriam a ativação produtiva dessas práticas coletivas realizadas por esses praticantes em sala de aula, de modo que, para compreender as práticas culturais de uma sala de aula, seja necessário analisar a rede de operações realizadas pelos praticantes (professora e estudantes) que ali estão. 
1.2.1 As práticas culturais no contexto escolar

O estudo das práticas culturais, em sua preocupação com os sujeitos sociais e suas experiências, ao aproximar-se das pesquisas no campo educacional, trouxe professores e estudantes para o foco das análises sobre a cultura escolar e permitiu aos pesquisadores pensarem esse espaço sob outra perspectiva que não o da transmissão cultural, sendo reconhecida, também como um espaço de construção e negociação de práticas e, mesmo, de uma cultura singular.

Essa cultura, como já apresentado nesta seção, pode ser descrita

como um conjunto de normas que definem conhecimentos a ensinar e condutas a inculcar, e um conjunto de práticas que permitem a transmissão desses conhecimentos e a incorporação desses comportamentos, normas e práticas coordenadas a finalidades que podem variar segundo as épocas" (JULIA, 2001, p. 10).

Essas práticas (re)construídas em sala de aula apresentam, como explica Vidal (2006), um conjunto de particularidades que a caracterizam como práticas culturais e demandam dos pesquisadores um conjunto de precauções ao tomá-las como objeto de estudo.

Inicialmente, é preciso ter em conta que essas práticas são “constituídas como meio dos sujeitos se situarem frente à heterogeneidade de bens e mensagens de que dispõem nos circuitos culturais" (VIDAL, 2006, p. 159). Em suas práticas, de forma nem sempre consciente, os praticantes reinventam os usos dos bens culturais, de modo que esses não devam "ser concebidos como dados, mas como um repertório a compor o léxico das práticas sociais" (VIDAL, 2009, p. 274). Em decorrência dessa primeira precaução, entender as práticas culturais como maneiras de fazer partilhadas por um grupo implica falar de maneiras específicas que se constituem como meios dos praticantes que compõem esse grupo situaremse frente aos repertórios de que dispõem nos circuitos culturais.

Esses repertórios (VIDAL, 2006) podem ser compreendido como o conjunto de bens tangíveis, aqueles que por terem materialidade podem ser tocados, tais como obras de arte ou objetos da vida cotidiana (utensílios domésticos, ferramentas laborais e vestuário, por exemplo); e de mensagens, intangíveis, tais como literatura, teorias científicas e filosóficas, os ritos, as músicas, assim como os padrões de comportamento ou de técnicas. Esses conjuntos de bens e mensagens estão disponíveis e partilhados pelos membros dos grupos sociais, sendo por meio desses que eles compreendem a realidade e agem sobre ela. 
A partir dessa explicação, para este trabalho, juntamente das ideias de práticas e operações culturais do Ensino de Ciências por Investigação, trazemos uma terceira ideia, a dos repertórios do Ensino de Ciências por Investigação que podem ser entendidos como o conjunto de bens e mensagens que são disponibilizados a estudantes e professores para implementação de atividades de ensino de ciências investigativas.

Retomando as precauções enunciadas por Vidal (2006, p. 158), como outro ponto de atenção para pensarmos as práticas escolares como objeto de estudo, é importante destacar que as assumir como práticas culturais "significa dizer que elas se exercitam em culturas específicas" e, mais ainda, que essas culturas específicas hibridizam "culturas familiares, infantis, docentes, administrativas, percebendo-as não como isoladas ou puras, mas como mestiças" (VIDAL, 2006, p. 159). Considerando essa hibridização, no contexto deste trabalho, ao analisar as práticas culturais observadas em uma sala aula na qual são promovidas práticas similares àquelas envolvidas em uma investigação científica, acreditamos ser possível que percebamos, também, a presença de indícios da cultura científica como constituinte da cultura específica daquele grupo. Partindo dessa ideia, como hipótese de fundo deste trabalho, propomos que, por promover um diálogo entre as ciências e a disciplina de Ciências, o Ensino de Ciências por Investigação possibilitaria que mais um matiz seja inserido em sala de aula, permitindo a constituição de uma cultura específica a qual denominamos científica-escolar. A cada contexto, essa cultura assumiria características ímpares em decorrência das distintas culturas que se hibridizam no espaço de cada sala de aula.

Como última das precauções enunciadas por Vidal (2006, p.158), temos que é necessário considerar que a característica mesma das práticas é ser praticada. Ou seja, as práticas produzem-se como um ato", de modo que é preciso traçar uma distinção entre práticas e prescrição de práticas. Temos inserida aqui a preocupação com as normas que organizam a ativação da prática pelos sujeitos e que, no contexto escolar, são apontadas por Julia (2001) como sendo a prescrição de condutas que devem estar presentes em sala de aula.

No contexto deste trabalho, uma vez que pretendemos analisar uma sala de aula organizada pelo ensino de ciências por investigação, entendemos que essa prescrição de condutas deve ser pensada a fim de criar oportunidades para que os estudantes se aproximem de práticas similares àquelas produzidas e partilhadas por membros das comunidades cientificas durante o processo de construção de conhecimento. Em virtude dessa potencial aproximação com as práticas científicas, consideramos que as normas vigentes em sala devem, também, se assemelhar àquelas que organizam o trabalho das comunidades cientificas no processo de proposição e apreciação de conhecimento a fim de garantir a ocorrência de 
interações discursivas críticas (LONGINO, 2002). Nesse sentido, falamos aqui de normas culturais do Ensino de Ciências por Investigação, como aquelas produzidas e partilhadas em sala de aula a fim de organizar a participação nos processos coletivos de proposição e apreciação de hipóteses durante o enfrentamento e resolução dos problemas. Desse modo, podemos ampliar nossa definição anterior das operações culturais do Ensino de Ciências por Investigação, afirmando-as como a ativação produtiva de práticas coletivas realizadas pela professora e pelos estudantes a partir das normas vigentes em sala.

Retomando a discussão proposta por Vidal (2006), neste trabalho, a última precaução apresentada acima se desdobra no esforço de caracterizar as práticas culturais de uma sala de aula, tanto como práticas praticadas, pela análise das interações vividas entre um grupo de estudantes e sua professora no momento de implementação de algumas atividades da SEI "Navegação e Meio Ambiente", quanto como prescrição de práticas, ao analisarmos a sequência como um documento norteador da aula utilizado pela professora para planejamento das aulas e que estabelece um repertório que deverá ser disponibilizado a ela e aos estudantes nos momentos de enfrentamento dos problemas propostos, bem como conhecimentos e condutas a serem trabalhados ao longo da resolução desses problemas.

Para uma melhor compreensão das práticas (prescritas e praticadas), antes de partirmos para análise das aulas, na seção que segue, buscamos discutir o Ensino de Ciências por Investigação como uma abordagem dentro do marco teórico do ensino de ciências como prática e das SEI, como operacionalização dessa abordagem. Nessa discussão, traremos o terceiro elemento presente na definição de Julia (2001): as finalidades atribuídas à escola como o eixo que coordena as variações das normas e práticas. 


\section{0 ensino de ciências como prática: novas finalidades para disciplina de Ciências}

Ciências da Natureza, Biologia, Física e Química, configuram entre as disciplinas escolares que devem compor uma base comum do currículo brasileiro a fim de que se garanta que, em sala de aula, circulem procedimentos e conhecimentos relacionados ao campo das ciências da natureza. Atualmente, a presença, as finalidades e as formas de organização de cada uma dessas disciplinas no interior do currículo são compreendidas como produtos de embates e mudanças nas práticas e nos campos epistemológicos, tanto da educação, quanto das ciências, entretanto, a construção histórica das disciplinas escolares como um corpo específico de saberes, nem sempre foi uma ideia prevalente.

Até os primeiros anos da década de 1970, para as áreas e teóricos que dedicaram-se aos estudos relacionados ao currículo, a construção das disciplinas escolares era, tradicionalmente, tida como um processo de deseruditização de conhecimentos elaborados fora da escola a fim de adequá-los às capacidades cognitivas infantis, sendo a escola vista não como um espaço de produção de um conjunto de conhecimentos próprios, mas como "um filtro de simplificação onde as ciências de referência depositam suas escórias, deixando passar apenas o essencial" (JULIA, 2002, p. 39). Como um exemplo de sistematização dessas premissas, na Grã-Bretanha, temos a proposição de Hirst e Peters (1970) de que as disciplinas escolares seriam traduções dos conhecimentos produzidos por uma comunidade de estudiosos, normalmente vinculada à produção acadêmica, para o uso no contexto escolar.

No Brasil, a partir dos anos 1980, temos os primeiros esboços de revisão desse discurso no "momento em que se repensava o papel da escola em suas especificidades como espaço de produção de saber e não mero lugar de reprodução de conhecimentos impostos externamente" (BITTENCOURT, 2003, p. 11). No processo de discussão dessa instituição, as disciplinas escolares tornam-se objeto de estudo de muitos pesquisadores e alguns autores, como Chervel, Goodson e Julia ganham grande repercussão no cenário nacional.

Como um dos principais críticos da ideia de transposição didática, Chervel (1990) concebe as disciplinas escolares como entidades epistemológicas relativamente autônomas, produzidas no interior da escola e nas pesquisas e políticas sobre e para a escola que buscam constituir métodos e conteúdos para abordagem dos diferentes domínios do pensamento, do conhecimento e das artes. Para o autor, um dos principais propulsores desses trajetos distintos seria o fato de as disciplinas escolares se sustentarem em objetivos próprios, muitas vezes irredutíveis às ciências de referência. 
Também destacando a autonomia das disciplinas escolares, Goodson (1983) afirma que muitas delas (matérias escolares, nas palavras do autor) possuem estruturas distintas das que sustentam as disciplinas acadêmicas e se constituem a partir de influências múltiplas e de uma diversidade de finalidades vinculadas a tradições utilitárias (ligadas aos interesses cotidianos das pessoas), pedagógicas (associadas à aprendizagem dos estudantes) e acadêmicas (voltadas para os interesses da formação universitária).

Partilhando de entendimento semelhante e dando destaque tanto às finalidades e conteúdos construídos pela escola, em suas práticas institucionais cotidianas, e para a escola, em ações externas a essa instituição, Julia (2002) defende que as disciplinas escolares só podem ser entendidas considerando-se de forma conjunta as finalidades explicitadas em documentos oficiais ou que podem ser inferidas pelas práticas; os conteúdos de ensino que figuram nos livros didáticos, manuais docentes, diretrizes curriculares, cadernos e outros materiais que circulam na escola; e os trabalhos e exercícios realizados pelos estudantes e que permitem ao pesquisador compreender a apropriação dos conteúdos.

De modo geral, na perspectiva desses autores, a escola é compreendida como um lugar de produção de um corpo de conhecimentos próprio que traz, sim, as especificidades de diferentes domínios do pensamento, do conhecimento ou das artes, mas que é constituído a partir da pluralidade de finalidades e conteúdos estabelecidos (pela e para escola); das práticas vividas no cotidiano escolar e dos resultados observáveis (por agentes internos e externos à instituição).

Aproximando essas perspectivas da disciplina de Ciências, Lopes (2005) explica que as disciplinas escolares são constituídas sobre alicerces epistemológicos, mais ou menos explícitos, similares àqueles das ciências, mas que, contudo, não são esses alicerces que definem as disciplinas escolares, uma vez que essas respondem a objetivos específicos dentro de um projeto social do que seja a função da escola, não se constituindo, portanto, como reprodução das ciências de referência. Para essa autora, no processo histórico de definição das disciplinas, os discursos instrucionais, "discurso especializado das ciências de referência a ser transmitido na escola" (LOPES, 2005, p. 260,) são deslocados de outros contextos academia, centros de pesquisa, órgãos oficiais, agências multilaterais, editoras - para o contexto escolar, e aí são reinterpretados, mesclados entre si, segmentados, enfim, recontextualizados em função dos objetivos de escolarização e do discurso regulativo, “associado aos valores e aos princípios pedagógicos" (LOPES, 2005, p. 266), constituindo um terceiro discurso: o discurso pedagógico. 
Dada essa recontextualização e a prevalência do discurso regulativo sobre o instrucional no contexto educacional, as disciplinas escolares não podem ser interpretadas segundo os princípios teóricos e metodológicos das disciplinas de referência. É nesse sentido, por exemplo, que os objetivos gerais propostos para o Ensino Fundamental (discurso regulativo) nos Parâmetros Curriculares Nacionais (BRASIL, 1997) precedem e se sobrepõem às especificidades da área de ciências naturais (discurso instrucional), trazendo para essa o compromisso (discurso pedagógico) de trabalhar com temas transversais; de promover a formação da cidadania, pela discussão, por exemplo, dos usos das tecnologias; de propiciar discussões para construção da identidade, pela construção da relação entre biológico e cultural; de considerar aspectos do desenvolvimento afetivo e de valores da criança, ao oportunizar outras leituras sobre a relação homem-mundo; ou de fomentar o trabalho com diferentes linguagens, explorando a oralidade e a narrativa durante os relatos de experiência, em respeito às fases do desenvolvimento infantil.

Para Lopes (2005), o que caracteriza essa recontextualização do que é produzido fora dos muros da escola para o espaço escolar é que ela se constitui de hibridismos, o que confere aos textos novos sentidos em sala de aula, em decorrência das finalidades específicas que ali assumem. No espaço curricular, "os textos são deslocados das questões que levaram à sua produção e relocalizados em novas questões, novas finalidades educacionais. Os processos simbólicos são desterritorializados e os gêneros impuros se expandem” (LOPES, 2005, p.267) em função do que é construído como objetivos e expectativas para a escolarização em uma sociedade.

Assim como os autores acima, sustentando a distinção entre as disciplinas escolares e as disciplinas acadêmicas, nesta seção, buscamos compreender a disciplina de Ciências como um componente do currículo escolar socialmente construído, destacando, entre outros, os discursos recontextualizados das ciências e as finalidades específicas atribuídas à instituição escolar e ao ensino de ciências. Em razão desse recorte, podemos perceber que, assim como se observam manutenções e mudanças nos discursos e finalidades, podemos observar, também, permanências e rupturas para o ensino de ciências.

Recontando parte desse processo, Zômpero e Laburú (2011) relatam que no período compreendido entre a segunda metade do século XIX e os dias atuais, a disciplina de Ciências passou e vem passando por sucessivas transformações em suas finalidades, conteúdos e exercício em decorrência das necessidades e demandas sociais, dos interesses políticos; dos debates promovidos entre pesquisadores e profissionais da educação que resultaram em 
mudanças na forma de se pensar e propor o currículo, o ensino e a avaliação escolar; e de novas perspectivas sobre o trabalho e o processo de construção do conhecimento científico.

Sintetizando esse processo de constante reconstrução vivido pela disciplina de Ciências, Stroupe (2014) apresenta quatro marcos teóricos que se destacaram ao longo do último século e que conceberam a aprendizagem e ensino de (1) ciências como lógica, no qual é enfatizado o papel da argumentação científica como um gênero sustentado pela lógica formal e por estratégias de pensamento desvinculadas do contexto teórico; (2) ciências como mudanças teóricas que enfoca as mudanças conceituais ao longo da história sob a ótica dos novos fatos acrescentados a uma teoria ou, eventualmente, da substituição de uma explicação científica por outra; (3) ciências como conhecimento acumulado que tem como núcleo a transmissão e memorização de dados e fatos elencados nos livros didáticos como síntese da produção humana sobre o mundo natural; e (4) ciências como prática, no qual defende-se que os objetivos de ensino expandam-se da apresentação de conceitos e métodos, passando a abranger também a participação nas dimensões sociais, epistêmicas e materiais do trabalho científico.

Segundo Stroupe (2014), os três primeiros modelos de ensino, promovem uma visão da disciplina de Ciências muito distanciada dos modos como se dá o processo de trabalho científico, apresentando os estudantes a métodos lineares e universais de construção e sistematização de conhecimento ou a um conjunto de fatos que devem ser conhecidos tendo em vista a superação de visões equivocadas sobre os fenômenos do mundo natural. Nessas propostas, ainda predominantes nas salas de aulas de ciências, por vezes, o professor é visto como aquele que detém a verdade sob a forma de informações e métodos científicos, de modo que caiba aos estudantes um papel passivo no processo de construção de ideias em sala de aula (STROUPE, 2014). Em contrapartida, na proposta de ensino de ciências como prática, temos uma redefinição dos papéis tanto dos estudantes, quanto dos professores, prevendo que esses trabalhem junto com seus estudantes, a partir das ideias que lhes são apresentadas, buscando criar oportunidades para que os estudantes reconstruam e aprofundem suas ideias e explicações sobre o mundo natural, enquanto se engajam em processos simplificados de trabalho científico. No interior desse marco teórico, toma-se

como pressuposto a importância de que o ensino de ciências traga para o centro da discussão aspectos que transitam entre os conceitos, as leis, os modelos e as teorias científicas e os elementos epistemológicos das ciências, tornando parte dos temas em discussão em aula os processos e métodos de investigação e as análises realizadas ao longo de sua execução e os fatores que balizam as escolhas por eles. Nosso entendimento é que, deste modo, os estudantes têm a oportunidade de compreender as ciências como área de 
pesquisa, como área que produz conhecimento e que constrói, observa e aprimora regras e práticas, em um mecanismo interno de avaliação constante (SASSERON; DUSCHL, 2016, p.53).

Esse entendimento repercute entre os pesquisadores do ensino de ciências uma vez que corresponde à atual premissa de que os estudantes aprendem de forma mais efetiva quando participam de atividades similares àquelas rotineiramente desenvolvidas pelos profissionais de uma determina área (STROUPE, 2015), de modo que práticas semelhantes às desenvolvidas pelas comunidades científicas devam integrar a disciplina de Ciências. Para tanto, é importante compreendermos que, em virtude dos diferentes objetivos que guiam as práticas científicas e as práticas escolares, essas se constituem, também, de formas distintas.

Conforme Berland et, al. (2016), o objetivo geral das comunidades científicas é construir modelos baseados em evidências que permitam explicar como e por que o mundo natural funciona das maneiras que ele faz, o que envolve uma gama de práticas que se alteram tanto em função de situações e objetos específicos das ciências, quanto em função do período e contexto em que essa busca se dá. Já para a escola, considerando especificamente o ensino de ciências como prática, os autores propõem que o objetivo deve ser construir um ambiente de trabalho coletivo no qual os estudantes tenham maior autonomia e sejam convidados a se envolver em investigações que lhes permitam compreender essas explicações sobre como e por que um fenômeno particular acontece, utilizando-se, para tanto, do repertório de comunidades científicas, como modelos e evidências.

Uma vez estando este estudo centrado nas normas e práticas culturais que são produzidas no espaço de sala de aula de ciências organizado pelo ensino por investigação, na seção que segue iniciamos a discussão de alguns significados que emergem no momento em que buscamos aproximar a ideia de prática científica e o contexto escolar. Esforço que se estenderá ao longo da discussão da análise.

2.1 Normas e práticas das comunidades científicas no contexto escolar: possíveis diálogos

Acompanhando um movimento mais amplo de mudanças com relação às expectativas depositadas sobre o ensino escolar e o papel social dessa instituição, bem como outras transformações com relação à visão sobre o processo de trabalho científico e à 
velocidade com que as ferramentas, tecnologias e teorias científicas são produzidas, as disciplinas de Ciências têm passado por revisões em suas finalidades, conteúdos e exercícios.

Dentre essas revisões, temos a constituição do marco teórico do ensino de ciências como prática em diálogo com a corrente perspectiva cultural que afirma que, uma vez que podemos identificar nas ciências valores, instrumentos, produtos, regras de funcionamento procedimentos, agentes e relações objetivas entre esses, é possível que as consideremos como una forma de cultura. Contudo, não sendo essas normas, repertórios e práticas fixas e imutáveis, mas sim variáveis ao longo dos períodos históricos em decorrência, entre outros, dos paradigmas vigentes ou dos meios disponíveis, é mais coerente que não falemos de uma cultura científica, mas de culturas situadas no tempo e espaço (SCARPA; TRIVELATO, 2013).

Nessa perspectiva, as práticas das comunidades científicas são compreendidas como inseridas em uma complexa rede social e o trabalho científico é tido como um processo social realizado em comunidades de pares nas quais o trabalho é orientado por um conjunto de valores e critérios normativas, ou em outras palavras, uma comunidade de praticantes envolvidos em práticas específicas consensualmente estabelecidas (OSBORNE, 2014). Considerando a existência desse conjunto de critérios normativos, acreditamos ser necessário pensar o ensino de ciências como prática envolvendo, também, a perspectiva das normas.

Como uma das autoras que tratam a construção do conhecimento com uma prática social, Longino (2002) compreende que o processo de construção e negociação do que conta como conhecimento incorpora normas construídas nas interações sociais e normas epistêmicas filosoficamente convencionadas que se aplicam tanto às práticas sociais, quanto aos processos cognitivos. Essas normas regem os processes de elaboração, comunicação, apreciação e validação do conhecimento, garantindo que as novas proposições e as apreciações das ideias propostas estejam alinhadas com os objetivos e com os padrões cognitivos das comunidades científicas. Nesse processo social, pelas interações discursivas críticas, teríamos garantida, também, uma maior objetividade das ciências "não por canonizar uma subjetividade sobre outras, mas por assegurar que o que é ratificado como conhecimento sobrevive à crítica de múltiplos pontos de vista" (LONGINO, 2002, p. 129). Pela análise do processo social de construção do conhecimento, Longino (2002) identifica quatro normas que garantem a ocorrência de interações discursivas críticas e, assim, resguardam a objetividade desse processo.

Segundo essa autora, para que ocorra o processo social de construção do conhecimento é necessária a: 
- Realização de fóruns, espaços publicamente reconhecidos para apresentação de pesquisas originais e para crítica e revisão daquilo que se apresenta (como evidências, métodos, suposições e argumentos)

- Receptividade à crítica, ou seja, o aceite da crítica e a reflexão a partir da mesma que pode levar a mudanças nas crenças e teorias de uma comunidade científica

- Presença de padrões públicos de análise, um conjunto de critérios e conhecimentos estabelecidos que organizam e dão suporte à apreciação de novas ideias

- Constituição de igualdade moderada entre os participantes de uma comunidade, relativizada por níveis de expertise ou conhecimento, mas não por uma posição social ou política

Em uma breve revisão de pesquisas que buscam caracterizar o trabalho realizado pelas comunidades científicas, podemos identificar diversas maneiras como essas normas são postas em prática. A fim de exemplificar cada uma das quatro normas no contexto de produção do conhecimento científico, trazemos alguns desses exemplos

Inicialmente, exemplificando a necessidade de existência de fóruns de apresentação e crítica de pesquisas, podemos falar da constatação de Latour e Woolgar (1997) de que durante o trabalho científico são produzidas anotações, relatórios, artigos e outras documentações do processo em execução. Além do permanente registro em cadernos, seguem os autores, são práticas quase que ininterruptas, a numeração e escrita em etiquetas, frascos, bandejas, tubos de ensaio ou mesmo nos animais analisados. Códigos ordenados e classificados que são observados periodicamente, arquivados ou descartados, alimentando novas análises e servindo de base para revisão e replicabilidade do trabalho realizado (MCCOMAS; ALMAZROA; CLOUGH, 1998). Nesse processo, as substâncias materiais são convertidas em tabelas, figuras ou diagramas utilizáveis pelos cientistas em suas argumentações. Inscrições que guardam relação direta com a "substância original" e podem ser comparadas, tornando-se ponto de partida para outras dúvidas e hipóteses, no esforço de construção de um corpo coerente de conhecimento. Nas palavras de Kropf e Ferreira (1997, p. 592-593), a inscrição literária

diz respeito à materialização dos objetos de estudo da ciência através de traços, pontos, gráficos, espectros e demais registros produzidos por aparelhos manipulados no sentido de formalizar literariamente os fenômenos que servirão posteriormente de matéria-prima para elaboração dos enunciados científicos. 
Destaca-se, assim, como o ponto central da atividade no laboratório, a geração de inscrições que serão analisadas e formalizadas sob a forma de artigos ou outros gêneros que garantem a clara e ampla divulgação e apreciação dos conhecimentos construídos (MCCOMAS; ALMAZROA; CLOUGH, 1998). Esses artigos, fruto de atividade experimental ou de outras modalidades de pesquisa, são divulgados para a comunidade, de forma a permitir que outros membros possam utilizar e avaliar as pesquisas realizadas sob outras visões, em espaços publicamente reconhecidos, como eventos e revistas científicas, sendo essas, eletrônicas ou impressas, "consideradas como o modo mais rápido e economicamente viável, para os pesquisadores fazerem circular e tornar visíveis os resultados do seu trabalho" (BROFMAN, 2012).

Já sobre a necessária receptividade à crítica, podemos falar da observação de Latour e Woolgar (1997) de que o trabalho realizado em um laboratório científico possui uma natureza distinta do realizado em um escritório ou fábrica uma vez que esse é perpassado pela constante justaposição dos trabalhos produzidos dentro e fora do laboratório. A produção do conhecimento científico inicia-se nos esquemas, quadros, documentos e artigos que o precedem e são questionados, aceitos, refutados e citados em novas proposições sistematizadas, arquivadas e publicadas. O que se destaca nesse processo de construção, é o pensamento divergente (PÉREZ et al, 2001) essencial ao trabalho científico, baseado no questionamento e no levantamento de hipóteses a partir de observações e conhecimentos anteriores. Ao ler e fazer anotações sobre um artigo, o cientista constrói novas perguntas e formula respostas provisórias a serem postas à prova em um exercício colaborativo e nãolinear que envolve erros e incertezas. Nesse sentido, a produção do conhecimento não é um ato isolado, mas envolve a tomada de questões anteriores, a consulta a produções contemporâneas e a própria condição e interesse das instituições às quais os cientistas estão filiados.

Para compreender a relevância dos padrões públicos de apreciação na construção do conhecimento científico, podemos falar da recusa ao dito "método científico", reconhecendo que a existência de distintas filiações teóricas nas comunidades científicas instaura um pluralismo metodológico (PÉREZ et al, 2001), uma diversidade de linhas para construção e apreciação do conhecimento que se adequam aos diferentes domínios investigativos é comungada por determinados grupos e varia ao longo do tempo, estabelecendo-se como critérios públicos apara apresentação, apreciação e revisão de ideias. Essa flexibilização metodológica é sustentada por referenciais teóricos que orientam a investigação, de modo que se caracterize, também, o trabalho científico pela aproximação da investigação a paradigmas 
aceitos pela comunidade científica. Mais ou menos aceitos em determinado tempo ou lugar, os paradigmas direcionam os interesses de pesquisa, mudam os destinos dos investimentos, definem a coleta e análise dos dados, orientam a construção de novas perguntas e proposições e distinguem o que é passível de publicação. Desse modo, não podemos deixar de compreender o caráter histórico e social (MCCOMAS; ALMAZROA; CLOUGH, 1998) inerente ao trabalho científico que se evidencia não apenas no fato de um dado paradigma vigente ser a síntese dos contributos de gerações de investigadores, mas também, pelo fato de as investigações serem respostas a questões colocadas pelas instituições. De modo similar, o trabalho dos cientistas e a produção de novos conhecimentos repercutem na sociedade.

Por fim, para pensarmos sobre a constituição de igualdade moderada entre os participantes de uma comunidade é preciso compreender o caráter social do desenvolvimento científico que, como propõem Pérez et al (2001), em detrimento de uma visão individualista e elitista das ciências, evidencia-se, entre outros, pelo fato de o trabalho científico ser orientado por linhas de investigação estabelecidas no interior das instituições, sendo essas que orientarão o trabalho em equipe e a atividade de pesquisa, estando a hierarquia e possibilidades de contribuições regidas pela perícia e não por critérios, por exemplo, de natureza social ou de gênero.

Ao trazermos exemplos que evidenciam as quatro normas sociais para o processo de construção do conhecimento por meio de interações discursivas críticas, destacamos algumas operações que são relevantes dentro de um grupo social, um conjunto de maneiras de registrar evidências, construir dados, apresentar hipóteses, criticar métodos e justificar alegações científicas que estão presentes no processo social de construção do conhecimento científico e que se manifestam de formas distintas em diferentes disciplinas científicas em virtude de seus domínios de investigação.

Sendo reconhecidas pelos membros de uma comunidade científica, essas ações padronizadas, passam a constituir parte da rotina de práticas dessas, sendo transmitidas e aprendidas pelas novas gerações por meio da participação e da interação com membros mais experientes. Essas práticas, próprias da investigação científica, podem encontrar um paralelo em sala de aula com os processos de produção de sentido sobre um fenômeno ou de construção de explicações protagonizados por estudantes, manifestando-se de formas distintas em diferentes abordagens de educação científica em decorrência das finalidades dessas (KELLY; LICONA, 2018).

Entre as pesquisas e diretrizes sobre educação que destacam que o conhecimento científico é produzido em comunidades de praticantes envolvidos em práticas específicas 
consensualmente estabelecidas, o termo "prática científica" tem ganhado espaço significativo referindo-se, de forma ampla, às propostas que localizam as expectativas de aprendizagem dos estudantes em torno da participação em certas práticas das comunidades científicas (DUSCHL, 2008; STROUPE, 2014, 2015; FORD, 2015). Todavia, em virtude da própria indefinição sobre o que caracterizaria essas práticas, não podemos dizer que exista um consenso sobre o que deva ser realizado em sala de aula a fim de promover essa participação.

Para Stroupe (2015, p. 1034) a prática científica pode ser definida "como as dimensões, tácitas e explícitas, do trabalho disciplinar, valorizadas e passíveis de aprendizado, que as pessoas desenvolvem ao longo do tempo em um lugar específico, como um laboratório, uma estação de campo ou uma sala de aula", de modo que falar em aproximar os estudantes das práticas das comunidades científicas implica a mudança de um enfoque que esteve ora no conteúdo, ora na argumentação lógica genérica para outro que se direciona para as ciências como realizações humanas realizadas no interior de uma complexa relação entre práticas cognitivas, epistêmicas e sociais.

De modo um pouco mais específico, Ford (2015) propõe que o ensino de ciências como prática refere-se à organização do ensino em torno do objetivo de que os estudantes aprendam como argumentar e agir cientificamente, o que não significa que se almeje que esses pensem e ajam, exatamente, como os cientistas fazem, mas que os estudantes possam ser ensinados, de alguma forma básica, sobre maneiras científicas de raciocinar e agir para que possam que desenvolver proposições confiáveis, ou, como propõe Duschl (2008, p. 269)

um senso de fazer que encarna os processos dialógicos de construção do conhecimento que estão no cerne da ciência, ou seja, obter e usar princípios e evidências para desenvolver explicações e previsões que representem nossas crenças mais bem fundamentadas sobre o mundo natural.

Sustentados em ideias similares, Windschitl, Thompson e Braaten (2008) propõem que o núcleo de trabalho da ciência está organizado em torno do desenvolvimento de explicações baseadas em evidências sobre o modo como o mundo natural funciona, sendo as práticas relacionadas a esse núcleo aquelas que devem ser incorporadas aos currículos de ciências. De modo geral, para os autores, essas práticas envolvem o processo criativo de desenvolvimento de hipóteses a partir de teorias ou modelos e o processo de teste dessas hipóteses com base em evidências derivadas da observação e da experiência.

De modo geral, nas perspectivas apresentadas, a ideia de prática não remete a um conjunto fechado de operações específicas nas quais todos os cientistas se envolvem, mas a uma epistemologia do conhecimento científico construída no interior da comunidade científica e mantida por ela. Ao participar de práticas dessas comunidades, os estudantes 
podem melhor compreender como os cientistas validam suas alegações, em suma, o que os cientistas têm de fazer para investigar o mundo natural e estabelecer um conhecimento confiável sobre esse.

Importante lembra, conforme explicam Bloome et al. (2005), que as práticas culturais encontradas na escola podem se aproximar de práticas comuns a outras instituições sociais ou espaços de interação, modificando-se e transformando-se em conjuntos de práticas específicas a cada sala de aula e que se fazem ver nos improvisos realizados pelo grupo, de modo que se torne necessário analisarmos a sala de aula em sua dinâmica fluida de permanências e transformações. Nas palavras dos autores, podemos dizer que as maneiras de fazer de dos diferentes campos disciplinares, da escola e de cada grupo em particular se encontram e se transformam de modo que

um estudante não, simplesmente, registra os resultados de um experimento de biologia e os submete de forma semelhante aos biólogos; em vez disso, os estudantes precisam considerar e responder ao contexto escolar, o que inclui evidenciar aquilo que aprendeu, suas realizações e a adesão às normas implícitas da sala de aula e da escola (BLOOME et al., 2005, p. 53).

Nesse sentido, propomos que, assim como podemos falar da "ciência escolar como um discurso híbrido, resultado de processos de aproximação, distanciamento e recontextualização entre culturas escolares e culturas científicas" (SCARPA; TRIVELATO, 2013 p. 91), podemos pensar as práticas culturais do Ensino de Ciências por Investigação, também, como resultante de processos de aproximação, distanciamento e recontextualização de maneiras de fazer da escola e das comunidades científicas.

2.1.1 A sala de aula de ciências como comunidade de práticas

A noção das ciências como um conjunto de práticas emerge de debates propostos por historiadores, filósofos e sociólogos das ciências ao longo dos últimos 40 anos e que evidenciaram que o conhecimento científico é realizado em uma comunidade de pares. Nesse contexto, também considerando que o processo de trabalho científico é permeado por aspectos sociais, políticos e culturais e está inserido em uma rede que inclui práticas e normas de participação específicas que foram historicamente construídas, Stroupe $(2014,2015)$ organiza quatro dimensões integradas da prática profissional das comunidades científicas que os novos 
membros dessas aprendem no contexto de suas rotinas diárias: dimensão conceitual, dimensão social, dimensão epistêmica e dimensão material. Partindo de premissa similar, Duschl (2008) destaca a importância de o ensino de ciências como prática harmonizar objetivos de ensino conceituais, epistêmicos e sociais a fim de que os ambientes de aprendizagem se configurem como comunidades de práticas.

Uma comunidade de práticas, como propõem Lave e Wenger (1991), pode ser entendida como uma organização espontaneamente formada entre praticantes que guarda a dupla característica de ser definida pelo domínio de interesse, pela identificação com um mesmo projeto, e não um trabalho pontual a ser realizado e pelo engajamento mútuo ao reunir profissionais dispostos a regular sua prática de acordo com as mesmas normas de conduta a fim de desempenhar suas funções da melhor forma possível. Em outras palavras, um grupo de pessoas que partilha de uma preocupação ou interesse comum e que, ao compartilhar experiências, recursos e conhecimentos a fim de elaborar novas abordagens e respostas a um problema, identificam e aprendem melhores maneiras de fazer, estabelecendo-as como práticas (WENGER; SNYDER, 2001).

Complementando essas duas, Wenger (2016) propõe ainda que as comunidades de práticas sejam caracterizadas pela partilha de um mesmo repertório, assim que, para falarmos a sala de aula como uma comunidade de práticas, não basta encontrarmos um conjunto de pessoas reunidas, mas sim que esse seja caracterizado pelo:

- Engajamento mútuo: Para constituição de uma comunidade é imprescindível que seus membros tenham meios de se falar, de interagir e de se apoiar na realização de suas atividades. Garantida essa livre interação, ainda que respeitadas as relações hierárquicas, deve-se garantir o direito de participação de todos os membros para que esses, que em suas competências individuais, possam engajar-se mutuamente em um mesmo empreendimento. Uma vez que, pelo convívio, os membros de uma comunidade estabelecem relações de poder, competição, colaboração, dependência, coleguismo, confiança, amizade, atração, antipatia, entre outras, é importante destacar que falar de engajamento mútuo não significa entender a comunidade de práticas como um conjunto homogêneo ou harmonioso, sendo possíveis tanto comunidades na qual o trabalho é desenvolvido de forma colaborativa, quanto outras em que as atividades são marcadas pela concorrência.

- Identificação com um projeto: Para constituição de uma comunidade, é importante que os membros se identifiquem com um projeto comum. Contudo, como a existência de uma comunidade não requer homogeneidade, a identificação com um projeto 
também não significa consenso na tomada de decisões, sendo as divergências, inclusive, produtivas para o processo de definição das formas de realização desse projeto. Nas discordâncias, os membros de comunidades negociam formas de trabalhar de maneira coordenada a fim de realizar seus projetos da melhor forma possível. Durante esse processo de negociação, ainda que não possamos negar a influência de fatores externos (econômicos, institucionais, políticas), deve existir protagonismo dos membros da comunidade de modo que os projetos nunca sejam, totalmente, determinados por agentes ou fatores externos. Ao negociar condições, recursos, responsabilidades e demandas o grupo dá contornos peculiares ao projeto desenvolvido, estabelece relações de confiança, estipula normas de participação e define critérios para definir aquilo que é relevante para seus membros, que ideias podem ser tomadas como pressupostos ou que ferramentas devem ser adotadas ou descartadas

- Partilha de um repertório: Ao longo do tempo, conforme se engajam da realização de projetos, os membros de uma comunidade criam recursos que os auxiliam na negociação de sentidos. Esses recursos constituem um repertório que pode ser bastante heterogêneo e que ganha coerência não pelas rotinas, palavras, gestos, aparelhos ou outros signos ferramentas que o constituem, mas pelo fato de terem sido produzidos e/ou adotados por uma comunidade de práticas durante a realização de seus projetos, sendo partilhados por seus membros. Esse repertório se caracteriza, também, por manter-se disponível para novas realizações, de modo que uma ideia legitimada, uma ferramenta ou símbolo anteriormente utilizado pode ser retomado por membros de uma comunidade em situações futuras.

No contexto de sala de aula de ciências, podemos pensar que um problema proposto possa levar estudantes e professor a interagir em busca de explicações e da construção de uma resolução coletiva. Pela natureza dos problemas propostos ou de outras questões que se desdobrem desses, o grupo pode se organizar em torno de um interesse comum, de modo que que as normas de participação que comumente regem as interações em sala de aula sejam negociadas, e o grupo passe a analisar o trabalho um dos outros, a partilhar procedimentos adotados, a comunicar e avaliar hipóteses a fim de construir explicações coletivas que levem à resolução das questões colocadas pelo e para o grupo, constituindo-se como uma comunidade de práticas.

Considerando a possibilidade de constituição dessas comunidades de práticas a partir da harmonização de objetivos conceituais, epistêmicos e sociais de ensino (DUSCHL, 2008) e 
acrescentando um quarto objetivo, relacionado à dimensão material incluída por Stroupe (2015), descrevemos quatro dimensões que podem integrar os objetivos para o ensino de ciências como prática e, potencialmente, conduzir à constituição da sala de aula como comunidade de práticas.

\begin{tabular}{|c|c|c|}
\hline Dimensões... & $\begin{array}{l}\text { do trabalho científico } \\
\text { (STROUPE, 2015) }\end{array}$ & $\begin{array}{c}\text { a serem integradas nos objetivos } \\
\text { para o ensino de ciências }\end{array}$ \\
\hline Conceitual & $\begin{array}{l}\text { como teorias, princípios, leis e ideias } \\
\text { são utilizados pelos membros das } \\
\text { comunidades científicas para } \\
\text { raciocinar e argumentar }\end{array}$ & $\begin{array}{l}\text { relacionada a conceitos, teorias, } \\
\text { princípios, leis e outros conteúdos } \\
\text { que os estudantes precisam para } \\
\text { construir, comunicar e apreciar } \\
\text { explicações científicas }{ }^{2} \text { para os } \\
\text { problemas que lhes são propostos }\end{array}$ \\
\hline Social & $\begin{array}{l}\text { como membros de uma comunidade } \\
\text { científica estabelecem normas e } \\
\text { procedimentos para manipular, } \\
\text { desenvolver, criticar e utilizar ideias }\end{array}$ & $\begin{array}{l}\text { relacionadas às normas e } \\
\text { procedimentos que devem ser } \\
\text { adotados no processo de construção, } \\
\text { comunicação e apreciação de } \\
\text { explicações científicas para os } \\
\text { problemas que são propostos }\end{array}$ \\
\hline Epistêmica & $\begin{array}{l}\text { as bases filosóficas a partir das quais } \\
\text { membros de uma comunidade } \\
\text { científica decidem o que eles sabem } \\
\text { e porque eles estão convencidos de } \\
\text { que sabem isso }\end{array}$ & $\begin{array}{l}\text { relacionada aos critérios para } \\
\text { decisão do que deve ser considerado } \\
\text { (dado, desenho de pesquisa, } \\
\text { resposta...) no processo de } \\
\text { construção, comunicação e } \\
\text { apreciação de explicações } \\
\text { científicas para os problemas que } \\
\text { são propostos }\end{array}$ \\
\hline Material & $\begin{array}{l}\text { como membros de uma comunidade } \\
\text { científica criam, adaptam e usam } \\
\text { ferramentas, tecnologias, inscrições } \\
\text { e outros recursos para apoiar o } \\
\text { trabalho intelectual }\end{array}$ & $\begin{array}{l}\text { relacionada às ferramentas, } \\
\text { tecnologias, inscrições e outros } \\
\text { recursos que podem ser utilizados } \\
\text { no processo de construção, } \\
\text { comunicação e apreciação de } \\
\text { explicações científicas para os } \\
\text { problemas que são propostos }\end{array}$ \\
\hline
\end{tabular}

Quadro 1 - Proposta de dimensões a serem integradas nos objetivos para o ensino de ciências construída a partir das dimensões com as quais, conforme Stroupe (2015), os novatos entram e contato e aprendem na prática de trabalho nas comunidades científicas

\footnotetext{
${ }^{2}$ Para este trabalho, a partir do que define o National Research Council (2011) como objetivo para o ensino de ciências como prática, compreendemos as explicações científicas como sendo aquelas produzidas nas interações em sala de aula durante o processo de enfrentamento dos problemas propostos na SEI. Essas explicações devem ser coerentes com as evidências disponíveis e incorporar a compreensão corrente que o grupo tem sobre o fenômeno em estudo, adotando ou não modelos representativos.
} 
Considerando que o ensino de ciências deve balancear objetivos conceituais, epistêmicos e sociais e compreendendo que a investigação, avaliação e o desenvolvimento de explicações e soluções são centrais no processo de construção de conhecimentos científicos, o National Research Council - NRC ${ }^{3}$ (2011) identifica oito práticas das comunidades científicas nas quais os estudantes de ciências devem ser iniciados: 1. Fazer perguntas; 2. Desenvolver e utilizar modelos; 3. Planejar e executar investigações; 4. Analisar e interpretar dados; 5. Utilizar pensamento matemático e ferramentas de informática; 6. Construir explicações; 7. Engajar-se em argumentações baseadas em evidências; 8. Obter, avaliar e comunicar informações.

A partir dessas oito práticas, organizamos categorias para identificação e análise das operações culturais do ensino ciências por investigação que nos guiarão no processo de análise. Para melhor compreender essas categorias, nesta seção teórica, detalharemos e discutiremos cada uma das práticas destacadas, conforme proposto pelo NRC (2011).

\section{Fazer perguntas}

Formular perguntas, seja para identificar o que já é conhecido na área, para guiar a construção de novas respostas explicativas ou para testar hipótese, é uma prática constante das comunidades científicas, sendo central que os estudantes sejam estimulados a fazer perguntas e que compreendam a importância das questões de pesquisa para o processo de construção de conhecimentos.

Crianças e adolescentes em qualquer etapa de ensino devem ser capazes de formular questões sobre os textos lidos, as características de um fenômeno observado ou as conclusões construídas após um processo investigativo. Conforme avançam nos anos escolares, as perguntas dos estudantes devem se tornar mais sofisticados e para que isso aconteça, é

necessária uma cultura de sala de aula que respeite e valorize boas questões,
que ofereça oportunidades para os estudantes refinarem suas questões e
estratégias de questionamento e que incorpore o ensino de estratégias de
questionamento efetivas em todos os anos escolares. Como resultado, os
estudantes tornar-se-ão cada vez mais proficientes em formular questões que
solicitam evidências empíricas relevantes; que buscam refinar um modelo,
uma explicação ou um problema de engenharia; ou que desafiam a premissa
de um argumento ou a adequação de um projeto (NRC, 2011, p. 59).

${ }^{3}$ O NRC é o consellho da Academia Nacional de Ciências dos Estados Unidos da América e foi responsável pela condução do trabalho de um grupo de 18 membros que levou à redação do $A$ Framework for K-12 Science Education. Esse grupo, formado por cientistas, pesquisadores do campo da educação e especialistas em políticas públicas, buscou compreender sobre o alcance e a natureza da educação em ciências, engenharia e tecnologia necessários para o século XXI, a fim de, posteriormente, guiar a construção dos parâmetros para o ensino de ciências escolar naquele país (Next Generation Science Standards), publicado em 2013. 


\section{Desenvolver e utilizar modelos}

Os modelos conceituais são representações, de certa forma, análogas aos fenômenos que representam, permitindo aos cientistas melhor visualizar e entender um fenômeno sob investigação, formular perguntas e explicações, comunicar ideias a outros membros das comunidades científicas ou desenvolver uma possível solução para um problema. O desenvolvimento, uso, avaliação e revisão de modelos e explicações desempenham um papel central na investigação científica (PASSMORE; STEWART; CARTIER, 2009, p. 395), pois oferecem diagramas, réplicas físicas, representações matemáticas, simulações computacionais ou outras representações que possibilitam ao cientista ir além do observável, contudo, como todos os modelos contêm aproximações, hipóteses e premissas que limitam o alcance de validade de sua aplicação e a precisão de seu poder preditivo, é importante que os estudantes reconheçam suas limitações e provisoriedade.

Em sala de aula, os estudantes podem iniciar a aproximação com os modelos desde os anos iniciais de escolarização, progredindo de registros do observado ou dos procedimentos de investigação, para representações que envolvam diagramas, mapas e outros modelos abstratos como ferramentas que lhes permitam tanto elaborar suas próprias hipóteses e conclusões, quanto apresentá-las a seus colegas de sala. Desse modo, os estudantes não serão, somente, apresentados a modelos conceituais já legitimados, mas poderão também se envolver na prática de elaborar e utilizar modelos, desenvolvendo "uma forma de metaconhecimento - ou seja, um conhecimento sobre aspectos específicos da ciência e o papel desses para explicar como sabemos o que sabemos" (OSBORNE, 2014, p. 184)

\section{Planejar e executar investigações}

Seja realizada em campo, em laboratórios ou a partir de revisões teóricas, uma prática importante dos cientistas é o planejamento e a execução de investigações que permitam responder a uma questão ou testar uma hipótese. Essa prática envolve a identificação de conhecimentos estabelecidos na área; o mapeamento de variáveis relevantes, considerando como elas podem ser observadas, medidas e controladas; a realização de observações; o levantamento de hipóteses; a coleta de materiais e a identificação do que deve ser registrado e considerado como dado; entre outros procedimentos que permitem testar teorias e explicações existentes ou revisar e desenvolver novas ideias.

A relevância de envolver os estudantes no processo de planejamento e tomada de decisões sobre o desenho de pesquisa está em apresentar esses procedimentos, mas também 
em afastar a prática escolar de propostas que se restringem à reprodução de etapas preestabelecidas em roteiros ou à aplicação de um mesmo procedimento em diversas investigações, sem que seja necessário ao grupo justificar as escolhas de material ou questionar os procedimentos adotados (OSBORNE, 2014).

No contexto escolar, para as primeiras aproximações dos estudantes dos anos iniciais com as práticas das comunidades científicas, é possível que as investigações sejam previamente estruturadas e algumas decisões sobre materiais ou sobre o que observar sejam direcionadas, entretanto, ao longo dos anos escolares, os estudantes devem ganhar autonomia de planejamento, escolhendo os caminhos da investigação e lidando com as limitações desses, ou mesmo, com a necessidades de revisão de um plano original. É fundamental, ainda, que os estudantes tenham vivências em sala que os permitam reconhecer que o laboratório não é o único local de realização de pesquisas científicas e que, para muitos cientistas, como alguns ecologistas ou geólogos, o mundo natural é o locus de pesquisa onde os experimentos são conduzidos e os dados são coletados (NRC, 2011).

\section{Analisar e interpretar dados}

A observação e as investigações científicas produzem um grande volume de materiais que, em seu estado bruto, podem ter pouco significado, devendo ser organizados, analisados e interpretados. Para tanto, os cientistas utilizam-se de uma variedade de ferramentas, como planilhas, tabelas, gráficos e análise estatística, para identificar os recursos e padrões significativos nos dados a fim de que esses possam ser utilizados como evidência.

Para realização dessa prática em sala de aula, o ponto central não deve estar na coleta de dados, mas na análise desses, em permitir que os estudantes percebam que algumas observações e procedimentos podem levar a resultados distintos e que é necessário estabelecer critérios de seleção de quais desses valem como dado, de quais métodos levam a resultados mais apurados e porquê (OSBORNE, 2014). Com esse fim, os estudantes precisam de oportunidades para analisar grandes conjuntos de dados e identificar correlações, o que amplia o alcance das experiências dos estudantes e ajuda a compreender a prática de análise e interpretação de dados. Além disso é central que estudantes percebam a necessidade de dominar determinados conteúdos para organização e leitura dos dados e que sejam capazes de aplicar conceitos e procedimentos para interpretação dos dados, estabelecendo e justificando as melhores interpretações.

\section{Utilizar pensamento matemático e ferramentas de informática}


A matemática é uma ferramenta essencial para as comunidades científicas, cumprindo a dupla função de ser uma das linguagens das ciências (função comunicativa) e de permitir o trabalho por dedução lógica (função estrutural). Com cada vez mais relevância para o trabalho científico, as ferramentas computacionais trazem novas possibilidades de trabalho e comunicação, bem como aumentam o potencial da matemática ao permitir cálculos que não podem ser realizados analiticamente. Juntas, essas duas ferramentas permitem a representação numérica de variáveis, possibilitam a previsão de resultados, fornecem modelos para descrever e prever fenômenos, auxiliam na coleta e análise de grandes conjuntos de dados, aceleram a busca por padrões distintos, ou mesmo, viabilizam a identificação de relações e características significativas de formas anteriormente impossíveis.

No contexto escolar, os estudantes devem ser estimulados desde cedo a utilizar-se de recursos da matemática e informática para formalizar suas interpretações e representar seus dados, a fim de, não somente, dominar essas ferramentas, mas de perceber o papel da matemática no trabalho das comunidades científicas, tanto como linguagem como estrutura.

\section{Construir explicações}

Um dos objetivos principais das comunidades científicas é a construção de explicações confiáveis sobre o mundo natural. Uma explicação é aceita quando se mostra superior a outras tanto na amplitude dos fenômenos que ela explica, quanto na sua coerência interna e com demais conhecimentos legitimados.

Em sala de aula, o envolvimento dos estudantes com construção de explicações apresenta a dupla função de apresentar explicações desenvolvidas e já legitimadas e de aproximar os estudantes de práticas epistêmicas das comunidades científicas, convidando-os a construir explicações a problemas propostos. Para tanto, em suas primeiras experiências com essa prática, os estudantes devem ser encorajados a desenvolver explicações sobre o que eles observam ao realizar suas próprias investigações, a avaliar as suas próprias explicações e a compará-la como outras indicando consistências e inconsistências com as evidências disponíveis. Gradativamente, eles podem começar a identificar e isolar variáveis e a incorporar as observações realizadas em suas explicações de fenômenos para, posteriormente, incorporar ferramentas mais complexas como modelos conceituais ou simulações matemáticas em suas explicações.

\section{Engajar-se em argumentações baseadas em evidência}


Nas comunidades científicas, a produção de conhecimento depende de um processo argumentativo no qual uma proposição justificada sobre o mundo é elaborada e, em resposta, apreciações à proposição e à linha de raciocínio são formuladas a fim de encontrar a melhor explicação para um fenômeno. Nessas comunidades, a argumentação também é necessária para resolver questões que envolvem, por exemplo, o melhor desenho experimental, as técnicas mais apropriadas de análise de dados ou a melhor interpretação de um dado conjunto de dados (OSBORNE, 2014).

Para o ensino de ciências, é importante que os estudantes percebam o processo de argumentação necessário para avançar e defender uma nova ideia ou explicação, bem como identifiquem e vivenciem as normas para a participação no processo argumentativo. Para tanto, devem apresentar explicações, mas também defender suas interpretações dos dados, avaliar criticamente os argumentos científicos de outros e apresentar contra-argumentos. Com isso, oferece-se aos estudantes "não só a oportunidade de usar seu conhecimento científico para justificar uma explicação e identificar as fraquezas dos argumentos de outros, mas também para construir seu próprio conhecimento e compreensão" (NRC, 2011, p. 73). A proposta é, portanto, de que os estudantes e professores se engajem em um processo discursivo crítico que leve o grupo a perceber que as afirmações feitas em sala, assim como nas ciências, precisam ser sustentadas por dados e garantias.

\section{Obter, avaliar e comunicar informações}

Uma das condições para o avanço dos conhecimentos científicos é a possibilidade de os membros das comunidades científicas comunicarem suas descobertas de forma clara e persuasiva e avançarem em novas discussões a partir de resultados encontrados por outros. Uma prática importante das ciências é, portanto, a comunicação e debate de ideias e dos resultados das investigações o que requer que os cientistas descrevam suas observações de forma precisa, exponham suas ideias, justifiquem seus argumentos e respondam a interpelações feitas.

Dada essa prática, o ensino de ciências deve ocupar-se em desenvolver a habilidade dos estudantes para ler e produzir textos específicos de gêneros intrínsecos às ciências. Para tanto, os estudantes precisam ser estimulados a interpretar textos científicos, relatórios e outras formas de comunicação científica, explorando, inicialmente com ajuda e depois de forma autônoma, a estrutura textual e seu conteúdo. A leitura acompanhada se faz necessária, pois, mesmo paras os estudantes letrados, os gêneros científicos trazem particularidades 
desafiadoras como termos pouco usuais ou linguagens específicas como diagramas, gráficos e símbolos matemáticos.

Além da leitura dirigida, é importante que os estudantes sejam convidados a registrar seus trabalhos, usando diários para anotar observações, pensamentos, ideias e modelos; a representar dados e observações com gráficos e tabelas, bem como com texto escrito; e a produzir relatórios ou outros gêneros de comunicação.

Cientes de que qualquer lista está sujeita ao risco de destacar ou descartar práticas, optamos por adotar as práticas prescritas pelo NRC (2011) como aquelas em que os estudantes de ciências devem ser iniciados, por estarem em acordo com o referencial teórico sobre o ensino de ciências adotado nesta pesquisa e por serem um esforço de elencar práticas das comunidades cientificas de modo a já relacioná-las com o contexto escolar.

Para seguirmos com as discussões sobre a possibilidade de a sala de aula se configurar como uma comunidade de práticas, resgatamos, a seguir, as quatro normas de produção do conhecimento científico apresentadas por Longino (2002) e que, conforme Kelly (2014), podem ser adaptadas para o contexto escolar, fazendo-se, ainda, necessária a investigação de como essas se constituem em sala de aula.

A fim de, justamente, conduzir essa investigação pela perspectiva das práticas promovidas pelo Ensino de Ciências por Investigação, propomos uma possibilidade de adaptação dessas normas, a partir das quais orientaremos a análise com o intuito de identificar e caracterizar as normas sociais que regem as comunidades de práticas que se constituem no espaço escolar. Para tanto, a partir do apresentado nesta seção, para a constituição de comunidades de práticas no contexto escolar nas quais haja efetiva participação de estudantes e professor no processo de construção de explicações científicas para os problemas propostos, podemos pensar nas seguintes normas sociais.

\begin{tabular}{|c|c|c|}
\hline Normas sociais... & $\begin{array}{c}\text { para construção de } \\
\text { conhecimento científico } \\
\text { (LONGINO, 2002) }\end{array}$ & $\begin{array}{c}\text { para construção de explicações } \\
\text { científicas para os problemas } \\
\text { propostos }\end{array}$ \\
\hline Fórum & $\begin{array}{l}\text { refere-se à necessidade de } \\
\text { existência de espaços } \\
\text { publicamente reconhecidos para } \\
\text { apresentação de pesquisas } \\
\text { originais e para crítica e revisão } \\
\text { daquilo que se apresenta (como } \\
\text { evidências, métodos, suposições } \\
\text { e argumentos) }\end{array}$ & $\begin{array}{l}\text { refere-se à necessidade de a sala } \\
\text { de aula se configurar em um } \\
\text { espaço de apresentação, crítica e } \\
\text { revisão de evidências, métodos, } \\
\text { hipóteses, argumentos, entre } \\
\text { outros }\end{array}$ \\
\hline
\end{tabular}




\begin{tabular}{|c|c|c|}
\hline $\begin{array}{l}\text { Receptividade à } \\
\text { crítica }\end{array}$ & $\begin{array}{l}\text { diz respeito ao aceite de críticas e } \\
\text { à reflexão a partir dessas que } \\
\text { pode levar a mudanças nas } \\
\text { crenças e teorias de uma } \\
\text { comunidade científica }\end{array}$ & $\begin{array}{l}\text { diz respeito ao aceite de críticas e } \\
\text { à reflexão e revisão de ideias a } \\
\text { partir dessas }\end{array}$ \\
\hline $\begin{array}{l}\text { Padrões } \\
\text { públicos de } \\
\text { análise }\end{array}$ & $\begin{array}{l}\text { são o conjunto de critérios e } \\
\text { conhecimentos estabelecidos que } \\
\text { organizam e dão suporte à análise } \\
\text { de novas ideias }\end{array}$ & $\begin{array}{l}\text { são o conjunto de critérios e } \\
\text { conhecimentos apresentados e/ou } \\
\text { estabelecidos com o grupo que } \\
\text { organizam e dão suporte à análise } \\
\text { de novas ideias }\end{array}$ \\
\hline $\begin{array}{l}\text { Constituição de } \\
\text { igualdade } \\
\text { moderada }\end{array}$ & $\begin{array}{l}\text { entre os membros de uma } \\
\text { comunidade, relativizada por } \\
\text { níveis de expertise ou } \\
\text { conhecimento, mas não por uma } \\
\text { posição social ou política, de } \\
\text { modo que todos sejam } \\
\text { considerados igualmente capazes } \\
\text { de contribuir }\end{array}$ & $\begin{array}{l}\text { entre os membros de uma sala de } \\
\text { aula, relativizada por níveis de } \\
\text { expertise ou conhecimento, mas } \\
\text { não por uma relação vertical de } \\
\text { poder entre professor e } \\
\text { estudantes, de modo que todos } \\
\text { sejam considerados igualmente } \\
\text { capazes de contribuir. }\end{array}$ \\
\hline
\end{tabular}

Quadro 2 - Proposta de normas que devem orientar a construção de explicações científicas em sala de aula elaborada a partir das normas para produção do conhecimento científico de Longino (2002)

Acreditamos que estando essas normas e práticas presentes em sala de aula, possamos falar na efetivação de uma proposta de ensino de ciências como prática na qual os objetivos de ensino expandem-se da apresentação de conceitos e métodos e passam a abranger também a participação legítima nas dimensões sociais, epistêmicas e materiais das ciências, possibilitando, assim, que a sala de aula se configure como uma comunidade de práticas. Mais ainda, uma vez sendo o Ensino de Ciências por Investigação apontado e associado a uma pluralidade de significados que remetem ao engajamento de estudantes em práticas similares às desenvolvidas pelas comunidades científicas (KELLY, 2014), acreditamos que, no processo de enfrentamento de atividades investigativas de ensino, estudantes e professores possam assumir a responsabilidade pela construção coletiva de explicações científicas e, nesse processo, negociar normas e práticas de participação, constituindo-se como uma comunidade de práticas. 
A fim de melhor compreender os limites e possibilidades de constituição dessas comunidades de práticas em sala de aula por meio de uma abordagem de ensino investigativa e de caracterizar as práticas e normas que se estabelecem entre estudantes e professores durantes a realização de atividades investigativas, ao longo deste trabalho analisamos a proposta e a implementação da SEI "Navegação e Meio Ambiente". Contudo, antes de apresentarmos a discussão dessas, trazemos algumas ideias sobre o Ensino de Ciências por Investigação, pensando-o como abordagem dentro do marco do ensino de ciências como prática. 


\section{O Ensino de Ciências por Investigação como uma abordagem para o ensino de ciências como prática}

Desde a segunda metade do século XIX, quando de suas primeiras ocorrências no discurso pedagógico, a relação entre educação científica e as atividades investigativas passou por uma série de variações, em razão das distintas finalidades que foram atribuídas ao ensino de ciências como resposta às diferentes demandas políticas, econômicas e sociais constituídas ao longo das décadas. Nesse processo, conforme apresentam Zômpero e Laburú (2011), essa relação foi assumida por diferentes propostas, dentre elas a de aprendizagem por descoberta, a de resolução de problemas, a de projetos de aprendizagem e a de ensino por investigação.

Segundo esses autores, as primeiras referências à relevância de as atividades investigativas integrarem os currículos de ciências remontam à segunda metade do século XIX quando cientistas da Europa e Estados Unidos da América questionavam a possibilidade de a didática do ensino de ciências seguir os mesmos moldes das demais disciplinas, uma vez que esse distinguia-se dentro do currículo escolar por oferecer práticas de lógica indutiva, precisando, portanto, levar os estudantes a observar o mundo natural de forma detalhada e, a partir dessas observações, construir generalizações. Naquele momento, essa visão de ciências subsidia a defesa de instalação de laboratórios e de organização de conjuntos experimentais para o contexto escolar, a fim de permitir aos estudantes verificar princípios e teorias apresentados pelos professores (DEBOER, 2006).

Como um segundo marco histórico, no final dos anos 1930, temos a crítica de Dewey à educação científica baseada na transmissão de fatos e à centralidade docente em detrimento do estímulo ao raciocínio e da atividade dos estudantes. No Brasil, essas ideias encontram maior repercussão nos anos 1960 (CABRAL, 2014), com a defesa de um processo investigativo em sala que se iniciasse com a proposição de um problema adequado às capacidades e habilidades dos estudantes, ou mesmo que fosse proposto por eles; passando pela formulação de hipóteses e pela coleta de dados a partir de experimentos; encerrando-se com a construção de conclusões.

Nos anos que seguem, as atividades investigativas permanecem como parte da educação científica ora voltadas à resolução de problemas de relevância social em resposta às necessidades que emergem do crescimento urbano, da imigração e da ausência de saneamento e políticas públicas de saúde; ora à formação de futuros cientistas, corrente essa com maior repercussão nos Estados Unidos da América no contexto da Guerra Fria (ZÔMPERO; 
LABURÚ, 2011). Já nos anos 1970, com a contribuição de estudos sobre a aprendizagem e, em específico, com o fortalecimento das ideias construtivistas, muitas críticas são tecidas ao ensino voltado à formação de cientistas e à corrente abordagem dada às atividades de laboratório.

Como algumas das reformulações que resultam desse processo, relatórios e diretrizes curriculares publicados nos Estados Unidos da América entre as décadas de 1980 e 1990 passam a recomendar que o ensino de ciências "deveria ser coerente com a natureza da investigação científica. Os estudantes, então, teriam que aprender determinados procedimentos como: observar, anotar, manipular, descrever, fazer perguntas e tentar encontrar respostas para as perguntas” (ZÔMPERO; LABURÚ, 2011, p. 72).

Desde então, entre pesquisadores e entre docentes, coexistem diferentes interpretações sobre o que seja um ensino coerente com a natureza da investigação científica, remetendo, inclusive, a abordagens e finalidades para o ensino divergentes entre si (KELLY, 2014). Em decorrência dessa polissemia, podemos encontrar na literatura e em sala de aula propostas nas quais a investigação é defendida, por exemplo, como o meio para o ensino de conhecimentos e práticas; propostas nas quais a investigação é vista como algo a ser apresentado e discutido com os estudantes como parte da natureza das ciências; ou mesmo propostas nas quais espera-se que as aulas transitem entre essas duas possibilidades. Contudo, como ponto comum, existe a premissa de que nas atividades investigativas "deve haver um problema para ser analisado, a emissão de hipóteses, um planejamento para a realização do processo investigativo, visando a obtenção de novas informações, a interpretação dessas novas informações e a posterior comunicação das mesmas" (ZÔMPERO; LABURÚ, 2011, p. 74 - 75). Convergem nessas propostas, como destaca Kelly (2014, p. 1377) a ideia de que o “objetivo educacional da investigação não deve ser somente atender a padrões, conceitos ou procedimentos específicos, mas sim desenvolver a capacidade de aprendizagens futuras. [...] O ensino por investigação deve desenvolver a capacidade de engajar-se em mais investigações"

A partir desse objetivo, Kelly (2014, p. 1364) elenca alguns desafios para o Ensino de Ciências por Investigação, estando o primeiro deles sustentado na premissa de que "os estudantes precisam de conceitos para aprender conceitos" de modo que os educadores não devem assumir que os estudantes são capazes de induzir conceitos científicos sofisticados a partir da experimentação ou do contato com fenômenos empíricos, devendo-se garantir que alguns conhecimentos de base circulem em sala para que, então, os estudantes possam se envolver em atividades e discursos similares aos das comunidades científicas e que permitirão 
novas aprendizagens. Como segundo desafio para o Ensino de Ciências por Investigação, remetendo à tríplice finalidade para o ensino de ciências apontada na seção anterior (objetivos conceituais, epistêmicos e sociais), temos a ampliação do foco nos conhecimentos produzidos ou nas práticas de laboratório para a participação em práticas das comunidades científicas que envolvam a criticidade do conhecimento produzido por meio, por exemplo, do julgamento epistêmico que envolva a avaliação de perícia ou de confiabilidade de uma fonte. Outro desafio refere-se à maior ou menor adequação dos tópicos e procedimentos a serem ensinados à abordagem investigativa, uma vez que alguns conhecimentos e práticas podem ser realizados dentro de abordagens centradas no estudante, enquanto outros exigem abordagens mais diretivas de ensino. De modo similar, enquanto alguns fenômenos podem ser facilmente replicáveis em sala para investigação, outros exigem uma escala de tempo, materiais ou práticas não compatíveis com o espaço escolar. Por fim, como quarto desafio, temos a questão da verticalização e da horizontalização do currículo, uma vez que o ensino de alguns conceitos, critérios epistêmicos e práticas sociais deve estar organizados ao longo de mais de um ano letivo ou necessitam envolver mais de uma disciplina escolar.

Tendo esses desafios em vista, percebemos como eficiente uma abordagem investigativa para o ensino que busque colocar o estudante frente a problemas cuidadosamente escolhidos e elaborados para que possam ser enfrentados e resolvidos em um ambiente planejado e promovido pelo professor, a fim de oferecer subsídios necessários para compreensão, enfrentamento e resolução dos problemas propostos; de suscitar a troca de ideias entre pares; de tornar necessário o levantamento, exame e validação de hipóteses; de conduzir a construção de conclusões coerentes; e de possibilitar a construção de práticas que permitam ao estudante conduzir investigações futuras.

Ressalta-se nessas ideias, a necessidade de planejamento e atenção constantes dos professores para que se garanta um encaminhamento das atividades com foco na observação, problematização, análise, criticidade e participação ativa e autônoma dos estudantes. Desse modo, por mais que tenhamos uma estratégia, potencialmente, investigativa sendo posta em prática, são nas táticas de utilização de professores e estudantes no espaço escolar que esse potencial se realiza e transforma a relação dos sujeitos com o conhecimento, com os materiais e entre si.

No contexto das pesquisas que buscaram repensar o ensino de ciências na perspectiva de aproximar os estudantes de práticas das comunidade científicas, temos a proposição das SEI, sequências de atividades planejadas por pesquisadores do LaPEF em torno de tópicos do currículo escolar, considerando os materiais e as interações didáticas, a fim de proporcionar 
aos estudantes a oportunidade de mobilizar conhecimentos prévios e de levantar e discutir ideias com seus colegas e professores em um processo de construção de entendimento dos conhecimentos científicos estruturados por gerações anteriores (CARVALHO, 2013).

\subsection{As Sequências de Ensino Investigativas}

Como já destacamos a partir de revisões de outros autores (KRASILCHIK, 2000; CARVALHO, 2013), o ensino de ciências esteve, tradicionalmente, pautado em exercícios de memorização de termos, fórmulas, fatos, dados e teorias. Todavia, quando pensamos no Ensino Fundamental, essa tendência torna-se ainda mais acentuada, seja em decorrência da fragilidade conceitual na formação de professores, seja pela crença desses com relação à capacidade de compreensão sobre os conhecimentos científicos que os estudantes nesta faixa etária possuem (VIECHENESKI; LORENZETTI; CARLETTO, 2012).

Para Lorenzetti (2002), no Ensino Fundamental e, em especial, nos anos iniciais dessa etapa da Educação Básica, o foco do ensino deve estar na compreensão dos conhecimentos científicos e nos processos percorridos para construção desses, sendo as atividades investigativas vistas como uma possibilidade metodológica para tanto (VIECHENESKI; LORENZETTI; CARLETTO, 2012). Como uma proposta que visa a oferecer diretrizes e materiais que cooperam para construção de um ambiente investigativo em sala de aula, permitindo que os professores conduzam os estudantes em práticas similares às desenvolvidas pelas comunidades científicas, as SEI, pensadas para os anos iniciais do ensino fundamental, estão sustentadas pelas pesquisas de Piaget sobre a construção do conhecimento e pela produção de Vygotsky sobre o caráter fundante do social no processo de construção do conhecimento.

A partir dos trabalhos de Piaget, Carvalho (2013) ressalta a importância do problema para a construção do conhecimento, sendo esse item essencial a uma abordagem investigativa para o ensino de ciências ao propiciar condições para que o estudante possa, para além de acompanhar a exposição do professor, construir sua própria linha de raciocínio, assumindo papel ativo no processo de aprendizagem.

Como segundo ponto da epistemologia genética piagetiana destacado no referencial teórico para planejamento das SEI, temos a ideia de que qualquer novo conhecimento tem 
origem em um conhecimento anterior de modo que, a cada atividade proposta, seja primordial saber os conhecimentos prévios, escolares ou cotidianos, que os estudantes partilham sobre o tópico tratado. A partir dessa ideia, podemos dizer que a problematização inicial da SEI, acompanhada de questões levantadas no processo de resolução do problema, serve como disparadora de situações de aprendizagem à medida que mobiliza novos conhecimentos que são ancorados em conhecimentos prévios e em experiências anteriores constantemente reelaborados. Nesse processo de reconstrução, estão presentes

duas condições muito importantes para o ensino e aprendizagem escolar: a passagem da ação manipulativa para a ação intelectual que tem lugar nesta construção, principalmente entre crianças e jovens, e a importância da tomada de consciência de seus atos nessa ação (CARVALHO, 2013, p. 3).

Segundo a autora, estes são aspectos centrais para planejamento do ensino de modo que seja essencial prever-se um experimento, jogo ou texto na questão inicial a serem explorados pelos estudantes, com apoio do professor, por meio de pequenas questões, sistematizações das ideias ou mesmo exposições complementares. Essa intervenção docente que conduz à tomada de consciência dos modos como a ação do estudante sobre o problema levou à sua resolução.

Nessa relação social proposta entre os estudantes e entre esses e o professor, temos a aproximação da abordagem investigativa de ensino com as ideias de Vygotsky, cabendo destaque, conforme Carvalho (2013), às defesas de que as relações entre indivíduos e entre esses e o mundo são mediadas por ferramentas culturais e de que, pelo uso dessas ferramentas, os sujeitos transformam ao mundo e a si mesmos de modo que podemos dizer que a linguagem utilizada em sala, mediadora das interações entre professor e estudantes, não apenas facilita processos mentais já existentes, mas transforma o funcionamento da mente.

Dessa perspectiva teórica, a utilização de ferramentas culturalmente construídas é constitutiva do sujeito, transformando suas maneiras de agir. Nesse sentido, para o planejamento das atividades, não caberia pensar os repertórios disponibilizados em sala como meros facilitadores, mas como elos intermediários que transformam a relação entre os sujeitos e o conhecimento e que, no caso das ferramentas próprias das ciências, permitem aos estudantes se apropriarem de seus conteúdos e, também, de seu repertório cultural, aproximando-se da linguagem e maneiras de fazer próprios do campo.

Outro conceito da perspectiva Vygotskyana sobre a construção social do conhecimento trazido para o planejamento das SEI foi o de zona de desenvolvimento proximal, o intervalo entre aquilo que o estudante faz de forma autônoma (nível de 
desenvolvimento real) e o que realiza com intervenção de seus pares ou adultos (nível de desenvolvimento potencial).

Nessa teoria, o desenvolvimento real refere-se às aprendizagens que já foram consolidadas, enquanto que o potencial pode ser compreendido como as habilidades ou conhecimentos em processo de construção, capazes de serem atingidos e consolidados com a orientação do outro. Ideia que entra como justificativa para o trabalho em grupo em que, por meio das discussões, trocas de ideias e ajuda mútua, os estudantes potencializarão suas possibilidades de construção colaborativa do conhecimento.

É à luz desses referenciais da psicologia da educação que Carvalho (2013, p. 9) propõe um planejamento em que cada atividade, material e interação didática sejam pensados como meio de "criar um ambiente investigativo em salas de aula de ciências de tal forma que possamos ensinar (conduzir/mediar) os estudantes no processo (simplificado) do trabalho científico".

Respeitado esse referencial teórico (discurso regulativo), no processo de construção das SEI não temos, como poderia ser dito na perspectiva da transposição didática, uma simplificação do conhecimento científico (discurso instrucional), mas a elaboração de sequência com finalidades, procedimentos e exercícios específicos (discurso pedagógico) que compreendemos dentro do marco teórico do ensino de ciências como prática.

$\mathrm{Na}$ aproximação entre as práticas das comunidades científicas e a escola são pensadas algumas etapas essenciais para o planejamento das SEI que podem ser repetidas conforme a complexidade do assunto a ser tratado, criando-se uma organização do espaço e do tempo escolar.

Como primeira etapa de trabalho, Carvalho (2013) pontua a necessidade de uma situação problema, seja experimental ou teórica, que introduza o tópico a ser trabalhado e que já permita aos estudantes, em pequenos grupos, realizar suas primeiras inferências e iniciar os trabalhos, orientados pelo professor que os auxilia em sua interpretação e busca envolver a todos nas discussões. Nessa proposta inicial, temos um importante ponto de aproximação entre as práticas das comunidades científicas e a escola, posto que, como ocorre no trabalho científico, a construção do conhecimento/explicação deve ser resposta a um problema. Contudo, dada a finalidade educativa, esses problemas não emergem de circunstâncias sociais, empíricas, históricas e conjecturais, mas são propostos na SEI e negociados em sala entre professor e estudantes.

Se podemos afirmar que toda investigação científica, como propõe Sasseron (2013), “envolve um problema, o trabalho com dados, informações e conhecimentos já existentes, o 
levantamento e o teste de hipóteses, o reconhecimento de variáveis e o controle destas, o estabelecimento de relações entre as informações e a construção de uma explicação" (p. 43), temos no trabalho com problemas, potencialmente, elementos das práticas das comunidades científicas reformulados pelo e para o contexto escolar. Nessa reformulação, o professor, a partir de seus objetivos de ensino, traz novos dados, evidencia as hipóteses levantadas nos grupos, constrói condições de controle das varáveis e medeia o debate para formulação de explicações. A investigação aqui, pela finalidade educativa, ganha outro sentido: não tratamos da produção de conhecimento sobre o mundo natural, mas da construção de entendimentos sobre o conhecimento produzido (OSBORNE, 2014).

Destacando o papel do professor e o protagonismo dos estudantes no processo de construção de explicações, temos outro ponto de aproximação entre práticas das comunidades científicas e a escola. Se no processo de construção do conhecimento científico, a observação, a experimentação, a construção e a análise de dados são orientadas por perspectivas teóricas validadas pelas comunidades científicas, em uma SEI a comunidade de sala de aula deve estabelecer suas formas de validação. As maneiras como esse processo de validação é efetivado será um dos focos da análise dos dados.

Após a resolução do problema, os estudantes devem partilhar as explicações construídas e os caminhos de investigação escolhidos, ponto em que temos outra aproximação com as práticas das comunidades científicas, mas que ganha contornos específicos em razão da finalidade educativa. Quando a resposta de cada grupo é partilhada com a sala, a comunicação dos conhecimentos construídos, própria do fazer científico, toma novos contornos. Se a escola é, por primazia, a instituição social de ensino que visa, entre outros, à incorporação de modelos de pensamento, a construção e partilha de explicações se dá em um sentido de exteriorização, pela comunicação das ideias construídas, mas também, em um movimento de internalização, pela tomada de consciência do vivenciado que permitam ao estudante compreende como o problema foi resolvido e o porquê do êxito

Para promover esse momento de partilha, mas também de sistematização coletiva de ideias, o professor pode conduzir os relatos por meio de questionamentos que explorem explicações causais e a busca por conceitos, retomando o vivenciado frente a novas informações que permitam aprofundar o que foi visto.

Em um momento final das SEI, Carvalho (2013) propõe que os novos conhecimentos discutidos devem ser transpostos para o contexto da realidade cotidiana dos estudantes. Ao pensarem em aplicações práticas para o construído em sala de aula, acredita-se que os estudantes ganham elementos para compreender a relevância social das ciências, bem como 
para aprofundar as descobertas que levem a uma desconstrução do que já lhes é familiar frente a uma leitura mais crítica do mundo. A conclusão de cada atividade é caracterizada, também por um momento de construção de textos ou desenhos que relatem os procedimentos e considerações.

A partir dessas etapas, os pesquisadores do LaPEF desenvolveram a SEI "Navegação e Meio Ambiente" como uma proposta de abordagem investigativa para o ensino de ciências no $3^{\circ}$ ano do Ensino Fundamental. Como diz Kelly (2014, p. 1376), contudo, “a eficácia dessa abordagem depende crucialmente de como ela é implementada, para quem, em que condições e para que fins", de modo que, neste trabalho, analisaremos a SEI tanto como documento norteador (prática prescrita), quanto como prática praticada em sala de aula, observando como a proposta é recriada entre professor e estudantes no momento de sua implementação.

3.1.1 A Sequência didática "Navegação e Meio Ambiente" como prescrição de práticas

A SEI analisada neste trabalho foi planejada para o terceiro ano do Ensino Fundamental e está inserida dentro de um currículo programático formulado para este segmento. A sequência é formada por onze atividades sem uma divisão exata por aulas, de modo que essas possam ser implementadas de acordo com o ritmo de cada grupo. Contudo, no planejamento da sequência, foi imaginado um período de trabalho semanal de uma hora e meia para desenvolvimento das atividades. 


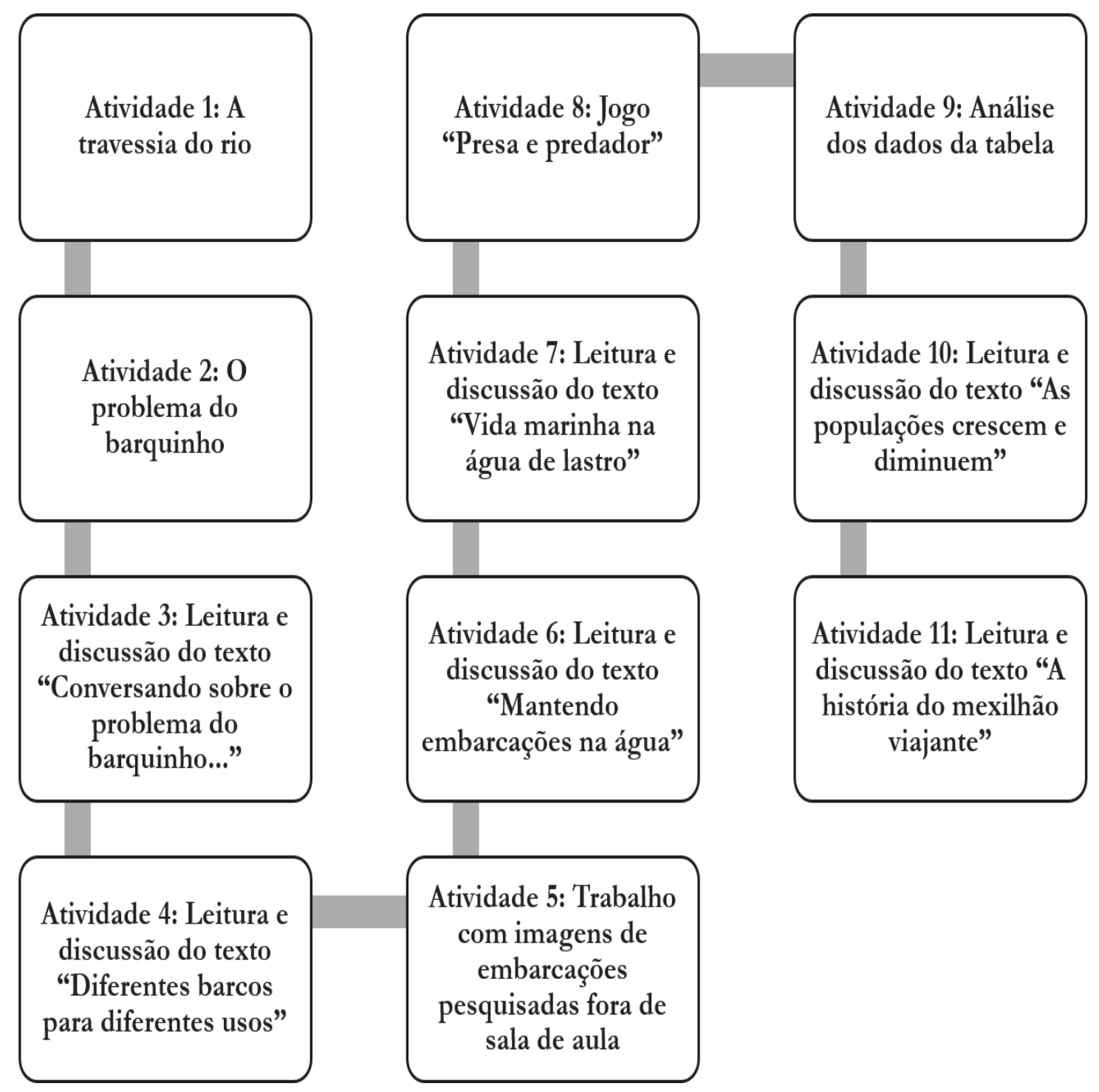

Figura 1 - Atividades integrantes da SEI "Navegação e Meio Ambiente"

Nesta seção, descrevemos cada uma das atividades a partir das orientações oferecidas aos professores e trazemos uma análise inicial dos objetivos gerais da sequência por meio do quadro a seguir que nos ajude a evidenciar quais dimensões da prática profissional das comunidades científicas aparecem integrando os objetivos da SEI.

\begin{tabular}{l|l}
\hline \multicolumn{1}{c|}{ Objetivos explicitados } & Dimensões \\
\hline $\begin{array}{l}\text { 1. Comunicar, de modo oral, perguntas, suposições, dados e conclusões } \\
\text { sobre a distribuição de peso nas embarcações, respeitando diferentes } \\
\text { opiniões e utilizando dados obtidos experimentalmente para justificar suas } \\
\text { ideias. }\end{array}$ & $\begin{array}{l}\text { Epistêmica e } \\
\text { social }\end{array}$ \\
$\begin{array}{l}\text { 2. Organizar e registrar informações sobre os tipos de embarcações por meio } \\
\text { de desenhos e pequenos textos que podem ou não ser elaborados com a } \\
\text { ajuda do(a) professor(a), dependendo do maior ou menor domínio da escrita } \\
\text { pelo estudante }\end{array}$ & $\begin{array}{l}\text { Conceitual, } \\
\text { epistêmica e } \\
\text { material }\end{array}$ \\
\end{tabular}


3. Localizar e utilizar informações sobre os problemas ambientais da água de lastro nos textos informativos presentes no material do estudante.

4. Comunicar, de modo oral, perguntas, suposições, dados e conclusões sobre a vida marinha na água de lastro.

5. Relatar, de modo oral, a existência de outras explicações para os fenômenos investigados, respeitando diferentes opiniões e culturas

6. Organizar e registrar informações sobre os problemas ambientais causados pela água de lastro por meio de desenhos e pequenos textos que podem ou não ser elaborados com a ajuda do(a) professor(a), dependendo do maior ou menor domínio da escrita pelos estudantes

Quadro 3 - Objetivos gerais para SEI "Navegação e Meio Ambiente"

Estando a dimensão material relacionada aos recursos que podem ser utilizados no processo de construção, comunicação e análise de explicações científicas para os problemas que são propostos, relacionamos a essa dimensão os objetivos (2 e 6) que envolviam o registro de informações por meio de desenhos ou pequenos textos que, nos primeiros anos do ensino fundamental, fazem as primeiras aproximações dos estudantes com a prática de desenvolvimento e utilização de modelos, bem como os auxilia a avaliar e comunicar que informações que, posteriormente, colaborarão para construção de explicações. Focando o aspecto comunicativo que também é abarcado pela dimensão material, associamos a essa o terceiro objetivo, pois visa a colocar os estudantes em contato com textos informativos, a partir dos quais terão mais elementos para planejamento e condução de suas investigações e construção de explicações.

Associados à dimensão social, relacionadas às normas e procedimentos que devem ser adotados no processo de construção, comunicação e análise de explicações científicas para os problemas que são propostos, os objetivos 1 e 4 trazem a finalidade de comunicar perguntas, suposições, dados e conclusões em um processo de partilha das explicações construídas e dos processos percorridos para tanto, o que permite que os estudantes apreciem os trabalhos um dos outros vivenciando as interações discursivas críticas próprias do processo social de construção de conhecimento. Prática que também é contemplado no quinto objetivo ao propor-se o relato de explicações alternativas para os fenômenos investigados, estimulando o pensamento divergente, comum nas comunidades científicas. Acreditamos que essa dimensão também possa ser encontrada nos registros dos estudantes, uma vez que eles acontecem a partir da construção coletiva de explicações, contudo, não fazemos esse destaque 
por considerarmos que esse seja um momento de sistematização individual das ideias. Assim, ainda que toda a SEI seja pensada de modo a promover interações o que se destaca nesses momentos de registro é uma organização de cada estudante e a tomada de consciência do processo vivido.

Com a dimensão epistêmica, relacionada aos critérios para decisão do que deve ser considerado no processo de construção, comunicação e análise de explicações científicas para os problemas que são propostos, conectamos os objetivos que dizem respeito à utilização de dados, obtidos experimentalmente ou provenientes de outras fontes, para justificar suas ideias, elaborar conclusões, levantar e questionar suposições (1 e 4); à seleção e à organização de informações (2, 3 e 6) que permitem ao grupo estabelecer critérios para escolha do que conta como justificativa para uma proposição, do que deve ser selecionado como informação relevante; e ao reconhecimento do que conta como explicação válida para os fenômenos investigados (5). Em cada uma dessas operações, os estudantes precisam estabelecer ou utilizar critérios que sejam reconhecidos pelo grupo como válidos.

Por fim, pensando na dimensão conceitual, relacionada a conteúdos que os estudantes precisam para construir, comunicar e analisar explicações científicas para os problemas que lhes são propostos, identificamos os objetivos que remetem a algum tema relacionado à navegação e ao meio ambiente $(1,2,3,4,6)$, tais como distribuição de peso nas embarcações, tipos de embarcações, a vida marinha na água de lastro e os problemas ambientais causados pelo uso desse procedimento no transporte aquaviário. Essa dimensão também pode aparecer no quinto objetivo, quando é sugerido que os estudantes relatem explicações para os fenômenos estudados, lançando mão, para tanto, dos conteúdos vistos A partir dos conteúdos apresentados ou aprofundados em sala, conforme a condução docente, os estudantes poderão fazer perguntas, construir explicações, engajar-se em argumentações, entre outras práticas das comunidades científicas.

Apresentados os objetivos da SEI, descrevemos cada uma das atividades que a compõem. Na apresentação da análise, a descrição das atividades A travessia do rio" (atividade 1), "Leitura e discussão do texto Mantendo embarcações na água" (atividade 6), "Leitura e discussão do texto Vida marinha na água de lastro" (7) e "Análise dos dados da tabela" (atividade 9) serão mais bem detalhadas, por serem essas as atividades que serão analisadas neste trabalho em sua prescrição e prática de sala. Por serem essas as atividades analisadas, disponibilizamos nos apêndices os textos e outros materiais oferecidos para os estudantes e sua professora para realização das mesmas. 


\section{Atividade 1: A travessia do rio}

Nessa primeira atividade, em grupos de 4 a 5 integrantes, os estudantes devem tentar resolver o seguinte desafio matemático: "Três homens querem atravessar um rio. O barco que possuem suporta no máximo 130 quilos. Eles pesam 60, 65 e 80 quilos. Como devem proceder para atravessar o rio, sem afundar o barco?".

Diferentemente do que veremos nas demais atividades, esse é um problema de caráter fechado que possui uma única resolução possível sustentada na argumentação matemática (anexo A). Ainda assim, “esperamos que os alunos, durante toda a realização desta atividade, argumentem entre si, explicitando suas hipóteses e construindo explicações e justificativas sobre o como e o porquê de terem conseguido resolver o problema" (SASSERON, 2008, p. 81).

Decorrido um tempo para discussão nos pequenos grupos, é importante que o docente conduza um momento de partilha das ideias levantadas, testadas, refutadas e aceitas, bem como de socialização da resolução correta. Feito isso, os estudantes devem registrar por com desenho e/ou escrita a solução encontrada e os meios para tanto.

\section{Atividade 2: O problema do barquinho}

Novamente em grupos de 4 a 5 integrantes, os estudantes são desafiados a resolver um problema prático: construir um barquinho capaz de carregar o maior número possível de pecinhas sem afundar na água. Para tanto, são disponibilizados para cada grupo folhas de papel alumínio, uma bacia (ou outro tipo de recipiente) com água e diversas pecinhas (arruelas, tampas de refrigerante, moedas, peças de dominó etc.).

Diferentemente da atividade anterior, dessa vez não há um único resultado possível, mas diferentes experimentações em que os estudantes podem perceber que a flutuação depende da distribuição uniforme das pecinhas (carga) sobre o barco e da relação entre a massa da carga a ser transportada e a área disponível para disposição dessa. Nessa proposta, cada grupo pode trabalhar com hipóteses próprias e colocá-las em teste.

Ao final da atividade, em um momento de comunicação dos procedimentos e resultados, o professor deve pedir que os estudantes relatem o processo de como resolveram o problema e do porquê de a solução ter funcionado. Após essa discussão, os estudantes devem registrar por escrito ou por meio de desenhos os percursos para solução do problema.

\section{Atividade 3: Leitura e discussão do texto "Conversando sobre o problema do barquinho..."}


$\mathrm{Na}$ proposta dessa terceira atividade, temos um caráter de sistematização e complementação das descobertas realizadas pelo grupo. Para tanto, os estudantes recebem um texto sobre a atividade anteriormente realizada e que destaca, como pontos centrais para resolução do problema, a área do barquinho e o modo como as peças são distribuídas sobre ele. Complementarmente, no texto, o problema da travessia é recordado a fim de reforçar as ideias de distribuição e de limite de carga de uma embarcação. Independentemente do modo coma a leitura será realizada, é importante que essa seja seguida de um momento de discussão sobre os pontos centrais do texto.

Após a discussão coletiva, quatro ilustrações de embarcações com cargas distribuídas de diferentes maneiras são disponibilizadas aos estudantes que devem escolher e justificar quais irão conseguir navegar em segurança. Ao realizar essa escolha, espera-se que os estudantes possam aplicar as discussões sobre a distribuição de peso em embarcações em outras situações.

\section{Atividade 4: Leitura e discussão do texto "Diferentes barcos para diferentes usos"}

Em grupos de 4 a 5 crianças, os estudantes devem realizar a leitura de um texto que apresenta informações sobre diferentes tipos de embarcações, seus formatos e finalidades, Nessa leitura, os estudantes entram em contato, entre outros, com as mudanças históricas vividas pelos meios de transporte aquáticos, os materiais utilizados para construção de algumas embarcações, as diferentes formas de propulsão dessas, além de um repertório lexical específico.

Ao final dessa atividade, os estudantes são convidados a pesquisar imagens e nomes de diferentes embarcações. Essa pesquisa será realizada na escola ou como tarefa de casa, a critério do professor.

\section{Atividade 5: Trabalho com imagens de embarcações pesquisadas fora de sala de aula}

Reunidos em pequenos grupos, os estudantes analisarão as imagens pesquisadas, comprando-as em seus formatos e funções. As ideias levantadas devem ser escritas em um exercício de correlação entre os usos das embarcações e seus formatos e depois partilhadas com a sala.

Em um segundo momento, as imagens devem ser dispostas e classificadas de acordo com critérios estipulados coletivamente. 
Nessa atividade, os estudantes recebem um texto informativo (anexos B e C) que apresenta a noção de lastro como alternativa para garantia da estabilidade das embarcações sem carga, os modos como esse recurso é utilizado, tipos de lastro e a forma mais comum utilizada hoje em dia: a água como lastro. Como essa noção será fundamental para as atividades que seguem, é crucial que o professor conduza uma discussão sobre a leitura, organizando as ideias principais.

Ainda nessa atividade, os estudantes são provocados a pensar sobre o uso do lastro em duas situações-problema que envolvem a estabilidade de embarcações em decorrência da presença ou ausência de carga.

\section{Atividade 7: Leitura e discussão do texto "Vida marinha na água de lastro"}

Dando continuidade às discussões da atividade anterior, o texto (Anexo D) a ser lido pelos estudantes aventa os possíveis impactos do transporte de seres vivos de um habitat a outro por meio da água dos tanques de lastro. Após a leitura, os estudantes são desafiados a pensar sobre o que aconteceria com seres vivos marinhos que são despejados em um local com condições climáticas adequadas, com muito alimento e longe de seus predadores.

Nessa discussão, é importante que o professor ressalte aspectos como as condições necessárias para garantia de vida dessas espécies invasoras e as prováveis consequências ambientais nos casos em que esses encontram condições favoráveis para sua reprodução. A discussão e conclusões são registradas pelos estudantes sob a forma de desenho e/ou escrita.

\section{Atividade 8: Jogo "Presa e predador"}

De forma bastante lúdica, sob a forma de uma brincadeira de pega-pega, essa atividade leva os estudantes a pensarem sobre a cadeia alimentar e os impactos advindos do crescimento ou da diminuição de uma das espécies que a constitui.

A fim de subsidiar essa discussão, antes do jogo, os estudantes realizam a leitura das fichas técnicas do tapiti e da jaguatirica, nas quais constam nome popular, nome científico e algumas características desses dois animais que comporão a cadeia.

Para iniciar o jogo, o professor divide a turma em três grupos com a mesma quantidade de participantes de modo que cada um deles represente as plantas, os tapitis (herbívoros) e as jaguatiricas (carnívoras). Caso a divisão não seja exata, as plantas deverão ser o grupo com maior número de representantes. Para facilitar a dinâmica do jogo, é aconselhável que a distinção entre as espécies seja de fácil visualização, com o uso, por exemplo, de crachás ou etiquetas coloridas. 
A cada rodada de 30 segundos:

- As plantas não se movimentam e podem ser pegas pelos tapitis

- Os tapitis devem tentar pegar uma planta e fugir da jaguatirica, podendo agachar-se como recurso de defesa quando se encontrarem em perigo

- As jaguatiricas devem tentar pegar um tapiti

Ao final da partida, o professor organiza os papéis que serão exercidos na rodada seguinte e anota em uma tabela o número de indivíduos de cada espécie que a comporá. Para essa organização, devem ser respeitadas as seguintes regras:

- As plantas que foram pegas passam a ser tapitis

- As plantas que não foram pegas seguem como plantas

- Os tapitis que foram pegos passam a ser jaguatiricas

- Os tapitis que não foram pegos nem pegaram plantas passam a ser plantas

- Os tapitis que não foram pegos, mas pegaram plantas seguem como tapitis

- As jaguatiricas que pegaram tapitis seguem como jaguatiricas

- As jaguatiricas que não pegaram tapitis passam a ser plantas

Ao final de 10 rodadas, os dados registrados constituirão uma tabela que será analisada na atividade seguinte.

\section{Atividade 9: Análise dos dados da tabela}

No início dessa atividade, mais uma vez agrupados, os estudantes receberão uma cópia da tabela produzida (Anexo E) na atividade anterior e uma série de perguntas (anexo F) que conduzirão a análise das informações.

Em um primeiro bloco, essas perguntas buscam evidenciar a relação entre o aumento ou a diminuição na quantidade de plantas e a existência dos tapitis. Em um segundo bloco, essas relações são ampliadas por questionamentos que consideram também a presença da jaguatirica.

Encerrada a discussão nos pequenos grupos, o professor deve conduzir um momento de partilha das hipóteses e repostas e, depois, convidar os estudantes a ler o texto "entendendo o jogo presa e predador" (anexo G). Por fim, as discussões devem ser registradas no caderno.

\section{Atividade 10: Leitura e discussão do texto "As populações crescem e diminuem"}

Nessa atividade, temos a sistematização e aprofundamento do vivenciado no jogo. Com a leitura, discussão do texto e registro das informações, os estudantes podem mais uma 
vez refletir sobre o equilíbrio entre as espécies envolvidas no jogo e ampliar essa discussão para outras populações de presa e de predadores, bem como se familiarizar com um vocabulário específico.

\section{Atividade 11: Leitura e discussão do texto "A história do mexilhão viajante"}

Articulando e sintetizando as discussões realizadas no decorrer da sequência, esse texto relata a introdução do mexilhão dourado no sul do Brasil por meio da água de lastro. Dentre outras informações, são apresentadas características da espécie, sua fácil adaptação ao novo ambiente, os impactos da presença de uma espécie exótica e possíveis medidas para lidar com as consequências danosas da proliferação dessa.

Após leitura e discussão, os estudantes devem registrar suas impressões sobre as consequências da vinda do mexilhão-dourado para rios brasileiros e o que se pode fazer para evitar os problemas causados por ele.

Nessa atividade, como em boa parte da sequência, temos a tríade leitura-discussãoregistro. Essa escolha nos mostra que a abordagem investigativa não depende exclusivamente de atividades experimentais, mas daquelas que ofereçam condições aos estudantes para que pensem e trabalhem com as variáveis relevantes do fenômeno científico em debate. 


\section{Metodologia e contexto de pesquisa}

Ao discorrer sobre a construção do texto científico, Orlandi (2006) propõe que o referencial teórico-metodológico de uma pesquisa não é, apenas, definidor dos modos de lidar com os objetos dessa, mas, também, dos próprios modos de concebê-los, posto que, pela adoção de um referencial, constituem-se diferentes sentidos e questionamentos sobre a realidade. Compartilhando dessa proposição, acreditamos que a escolha pelas práticas culturais como referência central desta pesquisa é, na mesma medida, definidora dos questionamentos que guia esta pesquisa e dos percursos adotados para respondê-los.

Nesse sentido, assumindo o pressuposto de que a cultura deve ser entendida como uma matriz de permutações possíveis, finitas em escolhas, mas incontáveis na prática (BAUMAN, 2012), e guardando lugar de destaque para o estudo das práticas culturais, optamos por um recorte de pesquisa que nos permitisse observar e compreender a possível constituição de uma comunidade de práticas em sala de aula, delimitando o contexto desta pesquisa a um estudo de caso descritivo instrumental (YIN, 2001; STAKE, 2005) que nos possibilitasse caracterizar as práticas culturais do Ensino de Ciências por Investigação, enquanto fenômeno social complexo.

A escolha pelo estudo de caso se justifica, pois, esse, como uma opção de recorte de pesquisa, permite a investigação de um tópico específico, preservando as características dos eventos da vida real (YIN, 2001). Para esta pesquisa, eventos ocorridos durante aulas de Ciências sobre os quais exercemos pouco controle, uma vez que, as operações da professora e dos estudantes não foram controladas, mas apenas observados por meio do registro audiovisual, ainda que os dados gerados sejam resultantes de aulas ministradas dentro de um processo de formação e acompanhamento específico coordenado por pesquisadores do LaPEF.

Nesta pesquisa, como próprio de um estudo de caso, buscamos investigar um fenômeno contemporâneo dentro de seu contexto concreto, no qual os limites entre o fenômeno e o contexto não estão claramente definidos (YIN, 2001). De forma mais específica, buscamos investigar práticas de uma professora e de estudantes de uma turma de $3^{\circ}$ ano de uma EMEF (o fenômeno) ao longo de algumas aulas de ciências organizadas a partir de uma SEI (o contexto) que disponibiliza novos repertórios a esses praticantes, que estabelece finalidades, conteúdos e exercícios específicos e que, potencialmente, permite a configuração da sala de aula como uma comunidade de práticas. 
Para tanto, dentre as qualidades de estudos de caso apresentadas por Yin (2001) exploratório, explanatório e descritivo -, a caracterização desta pesquisa como descritiva se justifica pelo fato de o objetivo primeiro dessa pesquisa ser descrever e analisar: quais normas e práticas culturais são produzidas no espaço de sala de aula de ciências organizado pelo ensino por investigação.

A partir dessa pergunta, guiamos o trabalho de pesquisa a fim de analisar algumas maneiras de fazer, as operações culturais do Ensino de Ciências por Investigação, e de verificar sua permanência, sua estabilização em práticas culturais. Dada a centralidade da pesquisa em discussões que nos ajudem a responder à pergunta posta e não nas particularidades da turma estudada, podemos dizer que o presente estudo de caso se caracteriza como instrumental (STAKE, 2005, p. 445) uma vez que o caso

desempenha um papel de apoio e facilita a nossa compreensão de outra coisa. O caso ainda é analisado em profundidade, seus contextos analisados e suas atividades comuns detalhadas, mas tudo porque isso nos ajuda a buscar o interesse externo.

Assim, buscamos elementos para discussão do ensino por investigação e de suas contribuições para o ensino de ciências pela análise da implementação das atividades propostas na SEI "Navegação e Meio Ambiente", sendo o caso em estudo um instrumento que pode nos ajudar a construir uma perspectiva de leitura desse fenômeno e, a partir dessa e de outros estudos comparativos e complementares, algumas generalizações (STAKE, 2005).

Antes de seguirmos com a apresentação de caso em estudo, ressaltamos que a elaboração e implementação da SEI analisada aconteceram em momentos anteriores ao início deste estudo, de modo que esses materiais já foram utilizados por outros participantes do LaPEF (SASSERON, 2008; AFONSO, 2011; LETTA, 2014; FREIBERG, 2015; RABONI, 2015; SOLINO, 2017) em dissertações, teses e relatório de pós-doutorado. Nesses trabalhos que analisaram a SEI e seu processo de implementação, foram encontrados indícios de que a sequência, enquanto prescrição de práticas, pode promover, por exemplo, a proposição e avaliação de hipóteses, a análise de dados, a discussão de variáveis e a construção de justificativas a partir dos problemas propostos, respaldando nossa hipótese de que as práticas em análise apresentarão singularidades próprias de uma abordagem investigativa para o ensino de ciências.

4.1 O caso em estudo: materiais e seu contex to de coleta 
Conforme o referencial teórico adotado para este trabalho, assumir as práticas culturais do Ensino de Ciências por Investigação como maneiras de fazer constituídas coletivamente implica ter sempre em vista que a característica mesma das práticas é ser praticada (VIDAL, 2006), ou seja, as práticas produzem-se como um ato, dando-se a ver por meio das operações de seus praticantes, de modo que, para sua análise, é importante ter-se em vista tanto a prescrição de práticas, quanto as práticas praticadas. Considerada essa premissa, como primeiro dos materiais de análise, temos a proposta didática da SEI "Navegação e Meio Ambiente" (prescrição de práticas), planejada para o $3^{\circ}$ ano do Ensino Fundamental na qual estão explicitados para a professora quais serão os objetivos, conteúdos e exercícios desenvolvidos a cada leitura, problema teórico, desafio prático ou demais atividades propostas.

Dentre as propostas da SEI, neste trabalho serão apresentados os planejamentos das atividades "A travessia do rio" (atividade 1), "Leitura e discussão do texto Mantendo embarcações na água" (atividade 6), "Leitura e discussão do texto Vida marinha na água de lastro" (7) e "Análise dos dados da tabela" (atividade 9). Essa escolha se justifica pelo fato de essas atividades mobilizarem diferentes finalidades, conteúdos e exercícios para o ensino de ciências o que, possivelmente, nos oferecerá mais elementos para caracterização de normas e práticas culturais que são produzidas no espaço de sala de aula organizado pelo Ensino de Ciências por Investigação, sem que nos centralizemos naquelas despertadas por um tipo de atividade específico.

Como segundo material de análise, temos o registro audiovisual da implementação em sala de aula da SEI "Navegação e Meio Ambiente" (prática praticada) realizado em uma EMEF localizada em um dos distritos mais setentrionais da Zona Norte da cidade de São Paulo e com um dos mais baixos Índices de Desenvolvimento Humano do Município, ocupando a $23^{\mathrm{a}}$ posição entre as 31 subprefeituras da cidade ${ }^{4}$. De modo mais específico, a escola onde a sequência foi implementada está situada em um bairro que teve sua construção iniciada em 1989, com a aquisição de lotes pela prefeitura visando à implantação de um conjunto habitacional que abrigasse famílias procedentes das áreas de risco da região. Durante os anos 1990, a nova gestão da prefeitura retirou apoio financeiro e interrompeu o processo de desapropriação de áreas para construção do conjunto habitacional, de modo que a constituição

\footnotetext{
${ }^{4}$ Conforme dados disponibilizados no Atlas Municipal de Gestão de Pessoas - Edição 2013, organizado pela Secretaria de Planejamento, Orçamento e Gestão da Prefeitura de São Paulo e disponibilizado para consulta em http://www.capital.sp.gov.br/
} 
do bairro seguiu em um processo desordenado de autoconstrução, o que resultou na constituição de uma das regiões de piores índices socioeconômicos do distrito e de maior vulnerabilidade social. Desde essa época, o bairro tem recebido famílias de migrantes dos estados da Bahia, Pernambuco e Alagoas que vieram para São Paulo em busca de trabalho e moradia $^{5}$.

No ano de 2012, quando da coleta de dados, a EMEF totalizava 540 matrículas de estudantes no Ensino Fundamental I, sendo que a maioria desses era de moradores do bairro. Cada uma das classes era formada por cerca de 30 estudantes e a escola contava com duas turmas de $3^{\circ}$ ano. Na classe em que a coleta de dados foi realizada, estavam matriculados 33 estudantes, sendo 17 meninos e 16 meninas, com idade a partir de oito anos.

Importante lembrar que, ainda que a SEI tenha sido adotada pela EMEF apenas a partir de 2012, já em 2010 iniciou-se uma parceria entre essa instituição e o LaPEF, que teve como principal objeto a oferta de encontros formativos envolvendo uma formadora desse laboratório e os professores da escola. Esses encontros formativos tiveram frequência mensal, com algumas variações a fim de ajustar-se ao calendário escolar, e foram realizados na própria escola com a presença de professoras de sala do Ensino Fundamental I, da formadora e de uma integrante do LaPEF, responsável por documentar os encontros.

De forma geral, os encontros abordavam os princípios norteadores do Ensino de Ciências por Investigação e serviram de espaço para discussão dos planos e aulas de ciências daquela EMEF. A partir do ano de 2012, algumas turmas da escola, dentre elas o $3^{\circ}$ ano, adotaram as SEI elaboradas e disponibilizadas pelo LaPEF e, em decorrência da adoção desse material, aos encontros formativos com toda a equipe do Ensino Fundamental I, foram adicionados encontros com as professoras de cada ano escolar. Esses encontros adicionais tinham por objetivos apresentar e aprofundar os conteúdos que deveriam ser trabalhados em sala, bem como discutir e planejar encaminhamentos e intervenções coerentes com a abordagem de ensino investigativo. Em virtude dessa parceria, a professora responsável pela implementação da SEI em análise neste trabalho já vinha participando de um longo processo de formação e discussões sobre os modos de condução de uma atividade de ensino investigativa.

No segundo semestre do ano de 2012, durante os meses de setembro e novembro, as professoras das turmas de $3^{\circ}$ ano conduziram a implementação da SEI "Navegação e Meio Ambiente", tendo suas aulas registradas por pesquisadores do LaPEF que nos precedem, mas

\footnotetext{
${ }^{5}$ Informações coletadas no site da Associação Cantareira, disponíveis em http://www.cantareira.org/
} 
que partilhavam do objetivo de compreender as interações vividas em sala de aula entre professores e estudantes. Dada a complexidade das interações que ocorrem no espaço escolar, optou-se pelo registro audiovisual como forma de coletar com maior riqueza de detalhes os gestos, deslocamentos, falas, entonações, pausas, expressões faciais, entre outros. Com esse fim, todas as aulas da SEI foram gravadas por duas câmeras, uma fixa por um tripé e outra manipulada por uma integrante do LaPEF.

Antes de se iniciarem as gravações, a professora e os responsáveis pelos estudantes assinaram um termo de consentimento livre e esclarecido autorizando o registro das aulas e a divulgação dos dados, desde que a privacidade dos participantes fosse respeitada. Com o objetivo de preservar a identidade dos estudantes e da professora, em conformidade com a resolução 510/2016 do Conselho Nacional de Saúde, que dispõe sobre as normas aplicáveis a pesquisas em Ciências Humanas e Sociais, os nomes dos estudantes, da professora e da escola não serão mencionados de modo que os nomes aqui citados e apresentados nas transcrições anexadas são fictícios.

Do total de aulas gravadas, serão analisadas neste trabalho a primeira (atividade 1), a quinta (atividades 6 e 7) e a sétima (atividade 9) aulas que correspondem à aplicação das quatro atividades selecionadas para análise. Como parte dos registros audiovisuais já foi utilizada por outros integrantes do LaPEF em trabalhos anteriores (FREIBERG, 2015; SOLINO, 2017), para o presente trabalho já estavam disponíveis transcrições das aulas que foram revisadas quanto à descrição das ações e gestos ocorridos; à divisão dos turnos, marcados pelo revezamento de locutores; e ao conteúdo das falas, conforme critérios apresentados no quadro 4 que sintetiza algumas das normas de transcrição apresentadas em Preti (2000). Das transcrições prévias, foram mantidos os pseudônimos utilizados a fim de facilitar possíveis diálogos entre os resultados encontrados.

\begin{tabular}{|l|c|}
\hline \multicolumn{1}{|c|}{ Ocorrências } & Sinais \\
\hline Incompreensão de palavras ou segmentos & (inaudível) \\
\hline Hipótese do que se ouviu & (hipótese) \\
\hline Entonação enfática & PALAVRA \\
\hline Prolongamento de vogal ou consoante & $: \ldots::$ \\
\hline Silabação & - \\
\hline Interrogação & $?$ \\
\hline Qualquer pausa & $\ldots$ \\
\hline Comentários descritivos do transcritor & $(($ comentário)) \\
\hline Superposição, simultaneidade de vozes & [trecho sobreposto] \\
\hline $\begin{array}{l}\text { Indicação de que a fala foi tomada ou interrompida em determinado } \\
\text { ponto. Não no seu início, por exemplo. }\end{array}$ & $(\ldots)$ \\
\hline
\end{tabular}


\begin{tabular}{|l|l|}
\hline Citações literais ou leituras de textos, durante a gravação & "trecho lido" \\
\hline
\end{tabular}

Quadro 4 - Critérios para transcrição das aulas construídos a partir de Preti (2000)

No processo de revisão das transcrições, algumas escolhas foram feitas, uma vez que a transcrição de um vídeo não consiste no registro escrito de tudo aquilo que pode ser visto ou ouvido, sendo necessário ao pesquisador, em decorrência de seu referencial e de sua questão de pesquisa, selecionar o que e como deseja transcrever (BLOOME; THEODOROU, 1998), o que, para este estudo se deu no sentido de transcrever todas as falas audíveis, deixando fora dos registros o gestual ou posição da professora e dos estudantes a cada interação. Essas falas foram organizadas em turnos delimitados conforme alternavam-se os locutores de modo que cada turno representa a fala de uma pessoa. Nesse processo dispusemos no papel diálogos que não aconteceram de forma tão ordenada quanto os quadros disponibilizados nos apêndices fazem parecer, tendo sido frequentes conversas de conteúdo incompreensível entre os estudantes, falas sobrepostas e ruídos de fundo, como movimentação de mobiliário.

As transcrições referentes às aulas que serão analisadas foram formatadas em quadros (apêndices A, B e C) compostos por duas colunas, nas quais estão explicitados o turno da fala e sua transcrição, eventualmente, acompanhado dos gestos e ações concomitantes que ajudam a compreender as operações e interações em curso. Em decorrência da qualidade do áudio, algumas dessas falas se perderam, sendo assinaladas como inaudíveis.

4.2 Uma proposta de análise

Como já apresentado nesta seção, a caracterização das práticas culturais do Ensino de Ciências por Investigação nesta pesquisa se dará pela análise da SEI "Navegação e Meio Ambiente" como prescrição de práticas e como prática praticada, a fim de nos ajudar a compreender tanto as normas, quanto as práticas vigentes em sala de aula no momento de implementação da SEI.

Para análise da prescrição das práticas, adotamos as dimensões que, segundo Stroupe (2015) devem ser integradas nos objetivos de uma atividade a fim de promover o ensino de ciências como prática. Nosso propósito com isso, era identificar se, no planejamento da SEI, haviam elementos que nos indicassem que as atividades sugeridas extrapolam a apresentação 
de conceitos e métodos (dimensão conceitual) e possibilitam abranger também a participação legítima nas dimensões sociais, epistêmicas e materiais das ciências. Contudo, a análise dos objetivos das atividades não foi suficiente para caracterização dessas dimensões que, com frequência, encontravam-se nas orientações para condução da aula e nos exercícios a serem realizados pelo grupo.

Para construção de dados que nos ajudassem a analisar o documento de planejamento em sua totalidade, adotamos os três eixos identificados por Julia (2002, p. 51) como essenciais para compreensão do funcionamento das disciplinas escolares, sendo esses, "as finalidades óbvias ou implícitas buscadas, os conteúdos de ensino e a apropriação realizada pelos estudantes, tal como pode ser medida por meio de seus trabalhos e exercícios". A partir desses três eixos, construímos um mapa para cada uma das atividades (quadro 5) que evidencia: (1) os objetivos explicitados nas atividades propostas e nas orientações aos professores, (2) os procedimentos de ensino construídos por meio dos conteúdos e métodos e (3) os exercícios para promoção e avaliação da apropriação por parte dos estudantes. Em cada um desse mapas, pela análise conjunta dos três eixos, é possível identificar e caracterizar elementos que remetem às diferentes dimensões do trabalho das comunidades científicas.

\begin{tabular}{l|l|l}
\hline Objetivos explicitados & Procedimentos de ensino & Exercícios \\
\hline & & \\
& & \\
\hline
\end{tabular}

Quadro 5 - Modelo de mapa da atividade

Para análise das práticas praticadas, aproximamo-nos de algumas ideias de Martins (2013) que, ao discutir questões metodológicas relacionadas à pesquisa em ensino de ciências, apresenta procedimentos para selecionar e recortar episódios de análise a partir de registros em vídeo da prática discursiva. Como diretriz metodológica para seleção dos episódios, destacando a natureza discursiva dos registros de interações entre professores e estudantes em situações naturais de sala de aula, Martins (2013) propõe que a delimitação das fronteiras de um episódio é um ato interpretativo do pesquisador sobre o material empírico a partir do referencial teórico adotado e de seus interesses de pesquisa.

Conforme nosso referencial teórico, as práticas culturais são constituídas como meios dos sujeitos se situarem frente aos repertórios que dispõem, não sendo individuais, ainda que individualmente ativadas, estando marcadas pelas normas que regem os grupos ou contextos 
sociais de seus praticantes (VIDAL, 2006), de modo que seu estudo deve enfocar tanto a ativação produtiva das práticas, mas também as normas que organizam as operações de seus praticantes. Tendo isso em vista e considerado nosso interesse de pesquisa, a definição de cada episódio se deu a partir da identificação de operações realizadas pela professora e/ou pelos estudantes durante o enfrentamento e resolução do problema proposto na SEI e que evidenciam as normas e as práticas vigentes a cada momento de aula.

Para escolha dos episódios apresentados na seção de análise, como nosso objetivo é qualificar e não quantificar as normas e práticas culturais do Ensino de Ciências por Investigação, selecionamos situações que ilustram diferentes operações, bem como elucidam os processos de constituição das normas e práticas em sala, existindo outras ocorrências similares às que compõem os episódios apresentados e que podem ser encontrados nos apêndices deste trabalho. Por esse mesmo motivo, em alguns momentos da apresentação da análise, optamos por destacar turnos ou trechos desses que trazem elementos para discussão, evitando, assim, que um grande volume de dados fosse trazido para a seção de análise, dificultando a leitura.

Realizada a delimitação de episódios a partir das transcrições das aulas, construímos um mapa para cada episódio que, como ressalta Martins (2013, p. 311), não

descrevem de forma objetiva e completa a sequência de eventos registrados na aula, mas eles certamente destacam quais eventos são significativos com relação aos nossos interesses específicos, interesses estes distintos daqueles que motivavam a pesquisadora que coletou os dados.

Esses mapas são organizados sob a forma de quadros com três colunas principais, sendo que, na primeira delas, são transcritos os turnos enumerados de fala com identificação do locutor, na segunda, as "evidências de normas culturais" e, na última das colunas, as "evidências de práticas culturais".

Como vemos no quadro 6, para organizar as evidências de normas culturais, a segunda coluna é subdividida em outras quatro onde são descritas as operações ou conjuntos dessas que remetam às normas que regem o processo social de construção de conhecimento (LONGINO, 2002), tais como adaptadas para este trabalho (fórum, padrões públicos de análise, receptividade à crítica e igualdade moderada). Para tanto, quando pensamos em operações que remetem às normas culturais, optamos por destacar tanto aquelas que acreditamos promover, quanto aquelas que acreditamos dificultar a promoção dessas normas. Ou seja, serão descritas, tanto operações do grupo que, por exemplo, promovam a apresentação e revisão de hipóteses, evidenciando que a sala, durante o episódio analisado, constitui-se como um fórum, quanto aquelas que, em outros episódios, frustrem a 
comunicação e avaliação de hipóteses e, portanto, indiquem que a norma de fórum não está vigente.

De forma similar, na terceira coluna, também teremos subdivisões que nos ajudarão a destacar as evidências de práticas culturais, por meio de operações ou conjuntos dessas que remetam às práticas das comunidades científicas descritas e categorizadas, conforme as oito práticas científicas (NRC, 2011) nas quais os estudantes de ciências devem ser iniciados a fim de compreendê-la como como um corpo de conhecimento, mas também como prática, como um processo de construção baseado em evidências, modelos e teorias pelo qual conhecimentos são construídos e revisados continuamente (fazer perguntas, desenvolver e utilizar modelos, planejar e executar investigações, analisar e interpretar dados, utilizar pensamento matemático e ferramentas computacionais, construir explicações, engajar-se em argumentações baseadas em evidências, obter, avaliar e comunicar informações).

Após identificar e descrever as operações que evidenciavam cada uma das normas e práticas, realizamos a validação da análise junto com os membros do grupo de pesquisa. Para tanto, foram apresentadas as transcrições das aulas e as categorias de análise acompanhadas de sua descrição e das operações que, a princípio, as comporiam. A partir desse material, nas reuniões do grupo, algumas operações foram substituídas, retiradas ou adicionadas, bem como foram revistos pontos da análise em que foram encontradas divergências.

Durante a análise e validação dos dados, nas tabelas referentes a cada episódio, foram mantidas as quatro subdivisões da coluna das normas, bem como as oito da coluna de práticas. Todavia, em razão da diagramação das páginas e na intenção de garantir uma melhor leitura dos mapas, a cada episódio, as subdivisões referentes às práticas ou às normas nas quais não foram relacionadas nenhuma operação serão ocultadas, como exemplificado no quadro 6.

\begin{tabular}{l|c|c|c|c|c|c}
\hline \multirow{2}{*}{$\begin{array}{c}\text { Turnos } \\
\text { (duração) }\end{array}$} & \multicolumn{3}{|c|}{ Evidências de normas culturais } & \multicolumn{3}{c}{ Evidências de práticas culturais } \\
\cline { 2 - 7 } & Fórum & $\begin{array}{c}\text { Padrões } \\
\text { públicos de } \\
\text { análise }\end{array}$ & $\begin{array}{c}\text { Igualdade } \\
\text { moderada }\end{array}$ & $\begin{array}{c}\text { Fazer } \\
\text { perguntas }\end{array}$ & $\begin{array}{c}\text { Planejar e } \\
\text { executar } \\
\text { investigações }\end{array}$ & $\begin{array}{c}\text { Construir } \\
\text { explicações }\end{array}$ \\
\hline $\begin{array}{l}\text { n. locutor: } \\
\text { enunciado }\end{array}$ & $\begin{array}{c}\text { praticante e } \\
\text { descrição da } \\
\text { operação }\end{array}$ & $\begin{array}{c}\text { praticante e } \\
\text { descrição da } \\
\text { operação }\end{array}$ & $\begin{array}{c}\text { praticante e } \\
\text { descrição da } \\
\text { operação }\end{array}$ & $\begin{array}{c}\text { praticante e } \\
\text { descrição da } \\
\text { operação }\end{array}$ & $\begin{array}{c}\text { praticante e } \\
\text { descrição da } \\
\text { operação }\end{array}$ & $\begin{array}{c}\text { praticante e } \\
\text { descrição da } \\
\text { operação }\end{array}$ \\
\hline
\end{tabular}

Quadro 6-Modelo de mapa de episódio

A fim de nos ajudar a perceber o diálogo entre proposto e praticado, os episódios estão agrupados subseções que representam grandes momentos da aula, conforme a condução 
da atividade. Esse agrupamento em momentos servirá, também, para reunir as discussões sobre as operações características de determina prática que, pensadas ao longo de um momento e, não apenas um episódio, puderam nos oferecer melhor compreensão sobre as maneiras de fazer criadas no grupo. Dessa forma, os momentos e episódios serão apresentados em ordem cronológica, mas a discussão pretende apresentar um panorama geral da aula, articulando turnos de episódios distintos.

Em sequência à análise dos episódios, apresentamos um quadro síntese (quadro 7) das operações identificadas que nos ajuda a discutir o processo de constituição das normas e práticas e as relações entre essas ao longo da aula. Esses quadros reúnem e descrevem as categorias constituídas a partir da análise dos dados

\begin{tabular}{l}
\hline \multicolumn{2}{c}{ NORMAS CULTURAIS DO ENSINO DE CIÊNCIAS POR INVESTIGAÇÃO } \\
\hline Fórum
\end{tabular}

- Síntese das operações descritas

\section{Receptividade à crítica}

- Síntese das operações descritas

Padrões públicos de análise

- Síntese das operações descritas

\section{Igualdade Moderada}

- Síntese das operações descritas

PRÁTICAS CULTURAIS DO ENSINO DE CIÊNCIAS POR INVESTIGAÇÃO

\section{Fazer perguntas}

- Síntese das operações descritas

\section{Desenvolver e utilizar modelos}

- Síntese das operações descritas

\section{Planejar e executar investigações}

- Síntese das operações descritas

\section{Analisar e interpretar dados}

- Síntese das operações descritas

\section{Utilizar pensamento matemático e ferramentas computacionais}

- Síntese das operações descritas

\section{Construir explicações}

- Síntese das operações descritas 


\section{Engajar-se em argumentações baseadas em evidências}

- Síntese das operações descritas

\section{Obter, avaliar e comunicar informações}

- Síntese das operações descritas

Quadro 7 - Modelo de quadro síntese das normas e práticas presentes na atividade

Pelo conjunto dessas ferramentas, ao final da análise, esperamos conseguir caracterizar normas e práticas culturais que são produzidas no espaço de sala de aula organizado pelo Ensino de Ciências por Investigação. De forma complementar, ao final das discussões, esperamos também ter elementos para discutir nossas hipóteses de fundo de que as SEI, ou ao menos a sequência em questão, podem promover a constituição da sala como uma comunidade de práticas com uma cultura própria na qual sentidos, signos, valores e ferramentas sejam partilhadas, possibilitando novas formas de ler e agir sobre o mundo (GÓMEZ; ADÚRIZ-BRAVO, 2007). 


\section{Ensino de Ciências por Investigação entre normas e práticas}

Nesta seção trazemos a análise das atividades da SEI tais como propostas e executadas. A partir do referencial teórico-metodológico já exposto, na presente análise procuraremos destacar as operações realizadas pela sala, compreendida como o conjunto de estudantes e sua professora, a fim de resolver os problemas propostos a cada aula, identificando e discutindo evidências de como normas e práticas que se estabelecem coletivamente.

\subsection{Aula 1 - A travessia do rio}

A atividade aqui analisada é a que inicia a sequência de ensino investigativa em estudo e foi realizada no decorrer de uma aula (cerca de 42 minutos registrados em vídeo) no dia 17 de setembro de 2012. A proposta é apresentada à professora como segue no mapa de atividade.

\begin{tabular}{|c|c|c|}
\hline Objetivos explicitados & Procedimentos de ensino & Exercícios \\
\hline $\begin{array}{l}\text { Levar os estudantes a } \\
\text { perceber que a necessidade } \\
\text { de obedecer ao limite } \\
\text { máximo de carga do barco } \\
\text { (neste caso, } 130 \mathrm{~kg} \text { ) exige } \\
\text { que ocorra a distribuição de } \\
\text { peso ao longo de viagens }\end{array}$ & $\begin{array}{l}\text { Organizar a turma em trios } \\
\text { ou quartetos para resolução } \\
\text { de um problema de lógica } \\
\text { matemática comum a todos } \\
\text { os grupos } \\
\text { Após a resolução do } \\
\text { problema pelos grupos, } \\
\text { promover discussão coletiva } \\
\text { sobre os procedimentos e } \\
\text { respostas } \\
\text { Durante a discussão com a } \\
\text { turma, sugere-se que o } \\
\text { professor faça perguntas para } \\
\text { que os estudantes contem } \\
\text { como fizeram para encontrar } \\
\text { a solução do problema }\end{array}$ & $\begin{array}{l}\text { Os estudantes devem resolver } \\
\text { o seguinte problema: } \\
\text { "Três amigos querem } \\
\text { atravessar um rio. O barco } \\
\text { que possuem suporta, no } \\
\text { máximo, } 130 \text { quilos. Eles } \\
\text { têm pesos de } 60,65 \text { e } 80 \\
\text { quilos. Como devem } \\
\text { proceder para atravessar o } \\
\text { rio, sem afundar o barco?" } \\
\text { Após resolver o problema, } \\
\text { cada grupo deve partilhar } \\
\text { com a professora e demais } \\
\text { colegas de sala quais } \\
\text { possibilidades de resolução } \\
\text { foram encontradas } \\
\text { Ao final da discussão, cada } \\
\text { estudante deve escrever e/ou }\end{array}$ \\
\hline
\end{tabular}


desenhar a solução do

problema no seu caderno

Quadro 8 - Mapa da Atividade 1 - A travessia do rio

Nesse mapa de atividade, podemos encontrar elementos que nos remetem, em diferentes níveis de complexidade, às quatro dimensões que devem compor os objetivos para o ensino de ciências como prática (STROUPE, 2015). Está presente nessa aula a dimensão conceitual, uma vez que é necessário que os estudantes compreendam a necessidade de distribuição da carga a fim de construir, comunicar e apreciar explicações para o problema matemático. Podemos falar, também da dimensão social, pelo fato de a SEI prever a comunicação e adoção de algumas normas para o processo de construção, comunicação e apreciação das explicações construídas, mas também, e talvez principalmente, por propor momentos de discussão coletiva e partilha de procedimentos e hipóteses. Nesses momentos, podemos identificar, ainda, a dimensão epistêmica à medida em que os grupos deverão apresentar os porquês do sucesso ou fracasso das respostas propostas, comparando os caminhos seguidos, o que deverá ser, ao final da aula, registrado em caderno. Tanto o registro da atividade, quanto a representação da travessia por meio das ferramentas disponíveis em sala corresponde à dimensão material.

Nessa proposta de atividade, ainda que como objetivo explicitado tenhamos foco na dimensão conceitual, acreditamos, como já indicado no quadro 3 quando analisamos os objetivos gerais da SEI, que existe a possibilidade de trabalho com as quatro dimensões da prática profissional das comunidades científicas, o que acreditamos que será efetivado de forma específica e com diferentes ênfases, conforme as operações dos estudantes e de seus professores no momento de implementação das atividades.

No caso estudado neste trabalho, quando posta em prática, a primeira atividade da SEI não acontece na sala de aula regular do $3^{\circ}$ ano, tendo sido a turma alocada em um espaço com mesas circulares que facilitaram o agrupamento dos estudantes. Nessa sala, a turma foi organizada em grupos com cerca de cinco integrantes, como é possível ver no vídeo e representado na figura abaixo. Na figura, os círculos representam as mesas e os retângulos escuros ao seu redor representam as cadeiras nas quais os estudantes estavam sentados. As áreas acinzentadas indicam regiões da sala que não foram capturadas pela câmera fixa, de modo que não foi possível identificar os estudantes e mobiliário. Durante a aula, a professora se manteve, na maior parte da aula, circulando nos corredores perpendiculares formados entre os grupos 2, 3, 5 e 6 . 


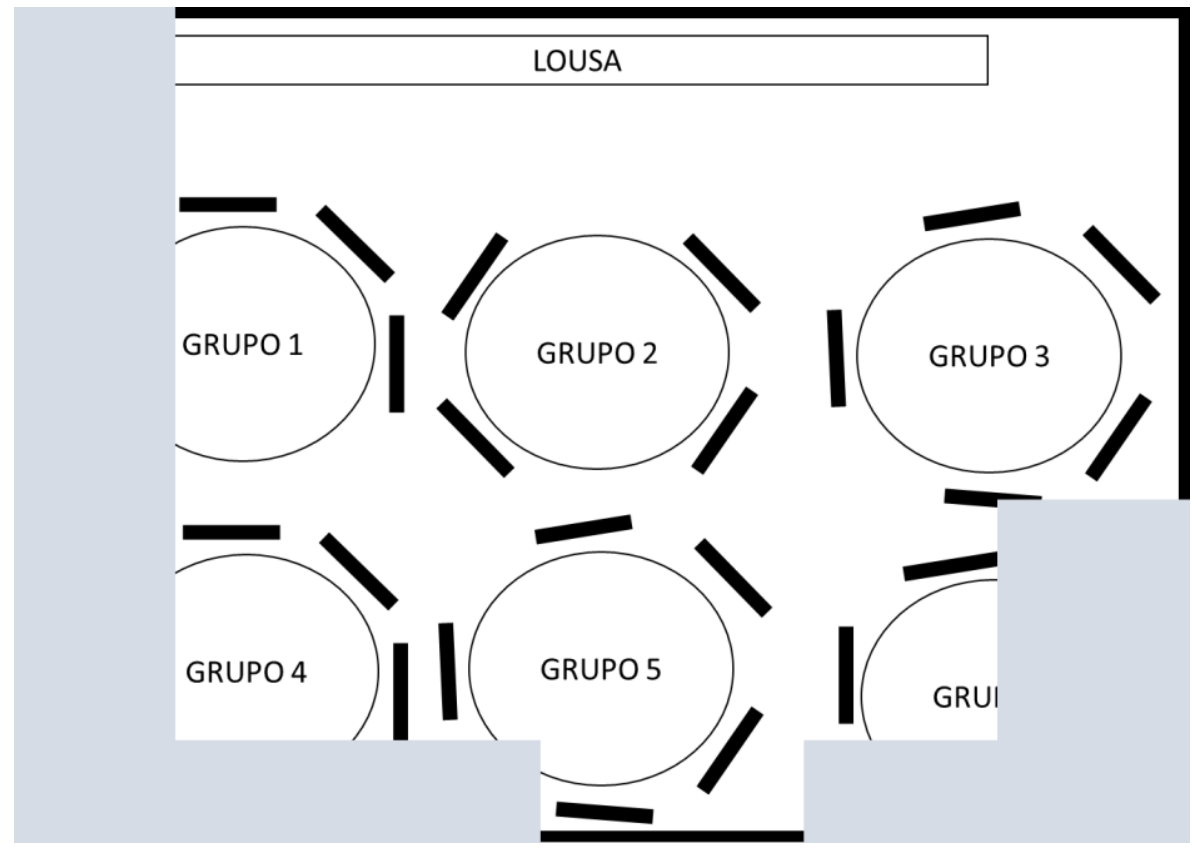

Figura 2 - Representação gráfica da sala, conforme registro em vídeo, durante a Aula 1 - a travessia do rio

A gravação desta aula tem início quando os estudantes já estão sentados e, na parede paralela aos grupos 1 e 4, podem ver uma projeção com o seguinte texto: "Três homens querem atravessar um rio. O barco que possuem suporta no máximo 130 quilos. Eles pesam 60, 65 e 80 quilos. Como devem proceder para atravessar o rio, sem afundar o barco?”. Além da projeção, como pode ser visto no vídeo, cada estudante recebeu uma tira de papel com o mesmo problema impresso e dispunha de seu caderno e estojo para registro.

Considerando o proposto na SEI e a condução da aula, podemos identificar cinco grandes momentos nos quais os episódios serão agrupados, conforme ilustrado a seguir. 


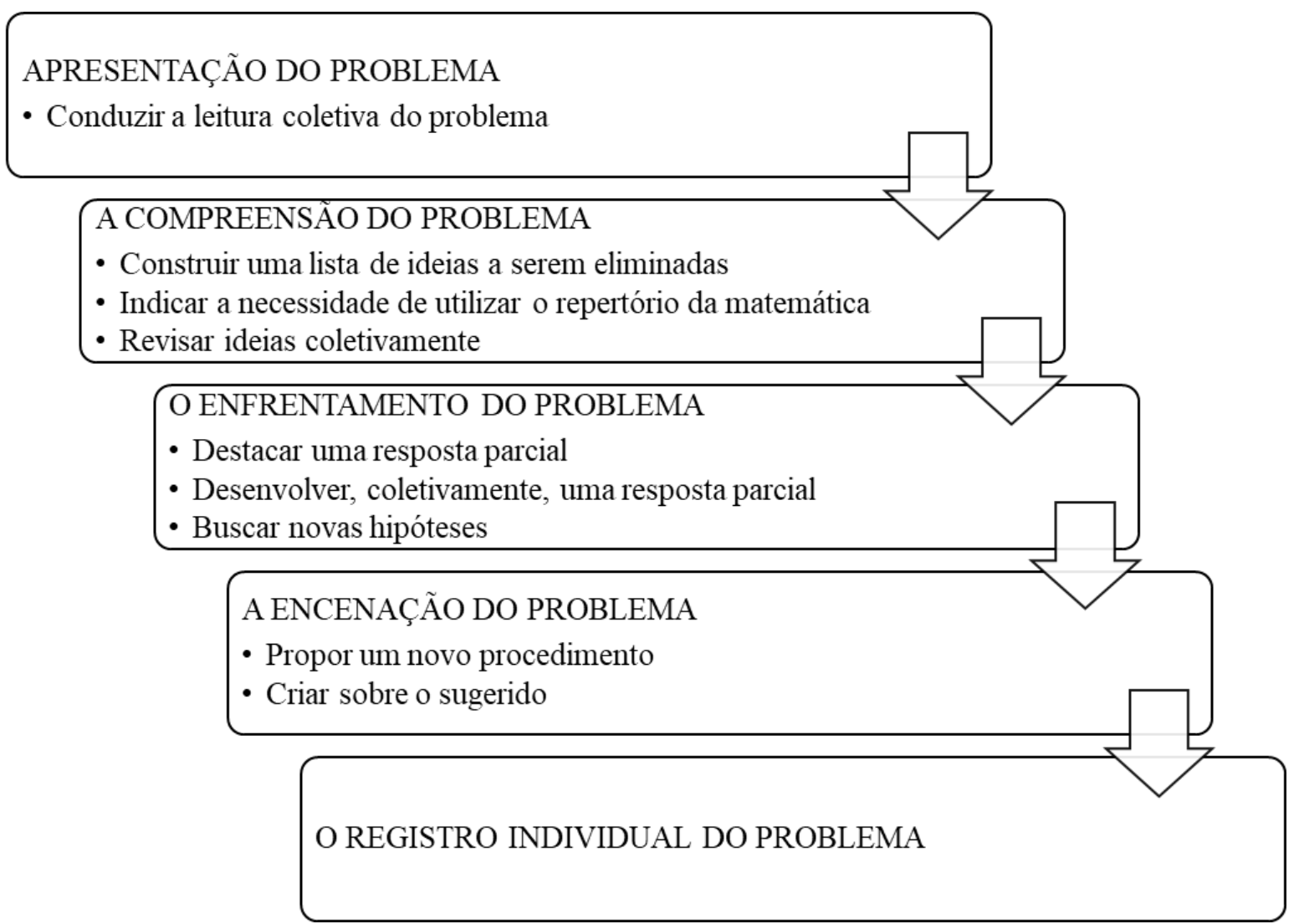

Figura 3 - Momentos e episódios da Aula 1- A travessia do rio

Nas seções que se seguem, buscaremos detalhar esses momentos a fim de analisar normas e práticas culturais promovidas em sala. O quinto momento, contudo, não será analisado uma vez que a filmagem foi interrompida logo que os estudantes receberam as instruções para realização dos registros sob a forma de texto ou desenho.

\subsubsection{A apresentação do problema}

Iniciamos o primeiro momento, composto de um episódio, no instante em que a professora cumprimenta a turma e explica que a atividade a ser realizada compõe o que denominam por "Projeto Ciências", ou seja, o conjunto de aulas realizadas dentro de uma proposta de ensino por investigação, conforme orientações recebidas ao longo dos encontros de formação organizados pelo LaPEF. Nesse episódio inicial, a professora apresenta o problema a ser resolvido e a maneira como os grupos devem trabalhar, conforme proposto na SEI. 
Conduzir a leitura coletiva do problema

\begin{tabular}{|c|c|c|c|c|}
\hline \multirow{2}{*}{$\begin{array}{c}\text { Turnos } \\
\left(00^{\prime} 0{ }^{\prime}-11^{\prime} 19{ }^{\prime}\right)\end{array}$} & \multicolumn{3}{|c|}{ Evidências de Normas Culturais } & \multirow{2}{*}{$\begin{array}{c}\text { Evidências de } \\
\text { Práticas } \\
\text { Culturais } \\
\text { Fazer } \\
\text { Perguntas }\end{array}$} \\
\hline & Fórum & $\begin{array}{l}\text { Padrões } \\
\text { Públicos de } \\
\text { Análise }\end{array}$ & $\begin{array}{l}\text { Igualdade } \\
\text { Moderada }\end{array}$ & \\
\hline \multicolumn{5}{|l|}{ 1. Professora: Bom dia } \\
\hline \multicolumn{5}{|l|}{ 2. Estudantes: Bom dia:::: } \\
\hline \multicolumn{5}{|l|}{$\begin{array}{l}\text { 3. Professora: Então a gente vai } \\
\text { continuar o projeto ciências e a aula de } \\
\text { hoje a gente vai começar com um } \\
\text { probleminha pra vocês resolverem }\end{array}$} \\
\hline \multicolumn{5}{|l|}{ 4. Estudante: A gente já resolveu } \\
\hline $\begin{array}{l}\text { 5. Professora: Não... ainda não.... } \\
\text { vocês receberam a tirinha com a } \\
\text { comanda do problema... aí está escrito } \\
\text { assim "pensa e resolva: três amigos } \\
\text { querem atravessar um rio... o barco } \\
\text { que possuem suporta no máximo } 130 \\
\text { quilos... eles têm pesos de } 6065 \text { e } 80 \\
\text { quilos... como devem proceder para } \\
\text { atravessa:... o rio SEM afundar o } \\
\text { barco"... primeiro vocês vão conversar } \\
\text { no grupo de vocês... primeiro é com } \\
\text { vocês em cada grupo... vocês vão } \\
\text { pensar como é que vai resolver isso... } \\
\text { quando o grupo chegar em uma } \\
\text { conclusão... pensar em uma maneira... } \\
\text { aí vocês vão me chamar para falar qual } \\
\text { é a ideia de vocês... aí a gente vai } \\
\text { ouvir a ideia de cada um pra ver qual é } \\
\text { a que vai dar certo... tá bom? então } \\
\text { pode começar }\end{array}$ & $\begin{array}{l}\text { professora } \\
\text { apresenta } \\
\text { planos de } \\
\text { trabalho }\end{array}$ & $\begin{array}{c}\text { professora } \\
\text { apresenta } \\
\text { critérios para } \\
\text { análise de } \\
\text { hipóteses }\end{array}$ & $\begin{array}{c}\text { professora } \\
\text { solicita } \\
\text { contribuições } \\
\text { professora } \\
\text { interrompe } \\
\text { contribuições }\end{array}$ & $\begin{array}{l}\text { professora } \\
\text { apresenta } \\
\text { problema }\end{array}$ \\
\hline
\end{tabular}

Quadro 9 - Episódio 1- Atividade 1- A travessia do rio - 17/09/2012

Nesse primeiro episódio, durante a apresentação do problema, vemos algumas operações que nos ajudam a compreender como as normas culturais vão se constituir ao longo da aula. Iniciemos pela norma de constituição de igualdade moderada que, como já apresentado anteriormente, é definida como a distribuição de autoridade intelectual em sala entre professor e estudantes, de modo que todos sejam considerados capazes de contribuir para o enfrentamento do problema proposto. Essa igualdade pode ser relativizada por níveis de expertise ou conhecimento, mas não por uma relação vertical de poder entre estudantes e professor. 
Considerando essa norma, destacamos a proposta da SEI de que o problema seja resolvido em grupos e de que, posteriormente, as possíveis resoluções sejam partilhadas com a professora e demais colegas de sala o que, a nosso ver, potencialmente, estabelece a igualdade moderada como norma para realização da atividade. Esse procedimento é enunciado pela professora no turno 5, quando ela apresenta um plano de trabalho (fórum) que todos devem seguir para construir, comunicar e avaliar hipóteses que serão, então, legitimadas coletivamente a partir da constatação de "qual é a que vai dar certo". Se acolhida pela turma, acreditamos que essa norma assuma papel central para a existência das demais e, com isso, para configuração da sala como uma comunidade de práticas, uma vez que o esperado não é a simples apresentação de ideias a serem triadas pela professora, mas o engajamento de todos e o reconhecimento do potencial de contribuição de cada um dos grupos.

Esse processo de construção e partilha de resoluções, como apresentado pela professora no turno 5, será norteado por condições estabelecidas no problema e que são partilhadas desde o início da aula como padrões públicos de análise, a partir dos quais as hipóteses serão propostas, analisadas e, então, acolhidas ou rejeitadas. Contudo, como veremos ao longo da análise, a aceitação desses padrões dependerá de um esforço da professora em reafirmá-los em oposição a outros critérios pautados na lógica cotidiana e que, inicialmente, orientam as respostas dos estudantes.

Ainda sobre as evidências das normas vigentes nesse episódio, destacamos a fala de um estudante não identificado que interrompe a professora ao afirmar "a gente já resolveu" o problema. Podemos inferir dessa fala que ele se referia a outra atividade, ou mesmo que já havia encontrado uma solução imediata para o problema, logo que o leu projetado na parede. Em todo caso, esse comentário é refutado pela professora que segue sua descrição, respondendo com um breve "não, ainda não".

Observamos na literatura estudos que indicam esse momento inicial da aula como um esforço necessário para que o docente ajude os estudantes a construírem um enquadramento do que vai acontecer naquela aula, de como a tarefa deve ser executada e das expectativas postas, o que parece afetar diretamente o desempenho dos estudantes e o sucesso das atividades planejadas (BERLAND; HAMMER, 2011). Entretanto, ainda que compreendida a necessidade de a professora oferecer uma resposta curta que não atrapalhe seu turno de "enquadramento", é importante destacar que essa operação parece interromper a apresentação de uma hipótese por parte de um estudante, dando-nos indícios de que, ao menos durante a apresentação do problema e organização da atividade, a ação se centra na docente e 
a igualdade moderada de participação e a configuração da sala de aula como um fórum não podem ser consideradas como normas postas.

Enfocando as práticas, podemos dizer que nesse episódio existem evidências do fazer perguntas no momento em que o problema é apresentado, tal como uma questão de pesquisa que nas comunidades científicas guia o processo de construção e revisão de conhecimentos. Para apresentação desse problema, a professora realiza a leitura do enunciado em voz alta, o que não estava indicado na SEI, mas pode ser interpretado como uma maneira adotada pela professora para ter pistas de que a turma compreendeu o problema a ser enfrentado e, também, para garantir que todos acompanhem o enunciado e iniciem a atividade em um mesmo instante, principalmente, se considerarmos tratar-se de uma turma dos anos inicias do Ensino Fundamental, etapa na qual a fluência de leitura ainda está sendo construída por muitos estudantes. Com isso, a professora garante também que, pelo seu tom de voz, determinados trechos do problema sejam destacados, o que podemos perceber pela ênfase dada na passagem "como devem proceder para atravessa:::r o rio SEM afundar o barco", que, potencialmente, indica aos estudantes a necessidade de considerar a distribuição de peso ao longo das viagens, objetivo específico a ser alcançado com a atividade e que aqui a professora parece realçar, ainda que de forma implícita, como critério para apreciação das explicações que serão construídas.

Encerrando esse episódio, a professora começa a circular pelos grupos verificando se os estudantes compreenderam o problema a ser resolvido. Os estudantes conversam nos grupos, mas o entendimento das conversas não é viável, contudo, conseguimos observar que alguns escrevem em seus cadernos e utilizam os dedos das mãos para realizar cálculos.

\subsection{2 $\mathrm{O}$ entendimento do problema}

O segundo momento, composto por três episódios, inicia quando a professora se aproxima do grupo 3 para explorar as hipóteses dos estudantes e guiá-los no trabalho investigativo. Ao ouvir as primeiras ideias desse grupo, a professora cria sobre as orientações da SEI e passa, aos poucos, a partilhar com toda a turma algumas das possibilidades de resolução apresentadas, questionando os estudantes sobre as mesmas e apontando inconsistências que parecem existir. Nesse movimento, a professora destaca condições relevantes para investigação e orienta a turma por um processo coletivo de entendimento do 
problema que resulta em possibilidades para que o caráter investigativo da atividade se realize.

Essa ou outras alterações sobre o planejamento recebido pela professora são possíveis estão de acordo com a proposta da SEI, uma vez que essa é pensada não como um roteiro a ser seguido, mas como um conjunto de diretrizes com relações aos materiais, procedimentos e exercícios para o ensino de ciências a serem adotadas e transformadas no contexto de sala de aula. 
Construir uma lista de ideias a serem eliminadas

\begin{tabular}{|c|c|c|c|c|c|c|c|c|}
\hline \multirow[b]{2}{*}{$\begin{array}{c}\text { Turnos } \\
\left(22^{\prime} 20^{\prime \prime}-4{ }^{\prime} 18^{\prime \prime}\right)\end{array}$} & \multicolumn{4}{|c|}{ Evidências de Normas Culturais } & \multicolumn{4}{|c|}{ Evidências de Práticas Culturais } \\
\hline & Fórum & $\begin{array}{l}\text { Receptividade à } \\
\text { Crítica }\end{array}$ & $\begin{array}{c}\text { Padrões } \\
\text { Públicos de } \\
\text { Análise }\end{array}$ & $\begin{array}{l}\text { Igualdade } \\
\text { Moderada }\end{array}$ & $\begin{array}{l}\text { Fazer } \\
\text { Perguntas }\end{array}$ & $\begin{array}{l}\text { Analisar e } \\
\text { Interpretar } \\
\text { dados }\end{array}$ & $\begin{array}{c}\text { Planejar e } \\
\text { Executar } \\
\text { Investigações }\end{array}$ & $\begin{array}{l}\text { Construir } \\
\text { Explicações }\end{array}$ \\
\hline $\begin{array}{l}\text { 8. Professora: E aí o que vocês } \\
\text { tão pensando? hã? não } \\
\text { entendi... então explica melhor } \\
\text { como é que é assim? como é } \\
\text { que é essa ideia? }\end{array}$ & & & & \begin{tabular}{|c|} 
professora \\
solicita \\
contribuições
\end{tabular} & $\begin{array}{c}\text { professora } \\
\text { faz perguntas } \\
\text { para guiar a } \\
\text { construção } \\
\text { de } \\
\text { explicações }\end{array}$ & & & $\begin{array}{l}\text { professora } \\
\text { solicita que } \\
\text { estudantes } \\
\text { apresentem } \\
\text { hipóteses }\end{array}$ \\
\hline $\begin{array}{l}\text { 9. Joana: Vai um no barco e } \\
\text { empurra o outro (inaudível) }\end{array}$ & $\begin{array}{c}\text { estudantes } \\
\text { apresentam } \\
\text { hipóteses }\end{array}$ & & & \begin{tabular}{|c|} 
estudantes \\
apresentam \\
contribuições
\end{tabular} & & & & $\begin{array}{c}\text { estudantes } \\
\text { apresentam } \\
\text { hipóteses } \\
\text { coerentes }\end{array}$ \\
\hline $\begin{array}{l}\text { 10. Professora: Gente a Joana } \\
\text { deu uma ideia aqui... ela falou } \\
\text { assim... que um vai... vai um } \\
\text { de cada vez só que ele vai e } \\
\text { empurra o barco de volta... só } \\
\text { que a distância é muito grande } \\
\text { e não dá para empurrar o barco } \\
\text { de volta... entendeu? }\end{array}$ & $\begin{array}{l}\text { professora } \\
\text { repete e } \\
\text { critica } \\
\text { hipóteses }\end{array}$ & & $\begin{array}{l}\text { professora } \\
\text { apresenta } \\
\text { critérios } \\
\text { para análise } \\
\text { de hipóteses }\end{array}$ & & & & $\begin{array}{l}\text { professora } \\
\text { mapeia } \\
\text { condições } \\
\text { relevantes }\end{array}$ & $\begin{array}{c}\text { professora } \\
\text { indica } \\
\text { inconsistências } \\
\text { em hipóteses }\end{array}$ \\
\hline 11. Estudante: Só ir nadando... & $\begin{array}{c}\text { estudantes } \\
\text { apresentam } \\
\text { hipóteses }\end{array}$ & $\begin{array}{c}\text { estudantes } \\
\text { apresentam } \\
\text { hipóteses } \\
\text { desconsiderando } \\
\text { críticas } \\
\end{array}$ & & \begin{tabular}{|c|} 
estudantes \\
apresentam \\
contribuições
\end{tabular} & & & & $\begin{array}{l}\text { estudantes } \\
\text { apresentam } \\
\text { hipóteses } \\
\text { incoerentes }\end{array}$ \\
\hline $\begin{array}{l}\text { 12. Professora: Não pode ir } \\
\text { nadando... tem que ir no } \\
\text { barco... então a gente tem que } \\
\text { eliminar algumas ideias aí para } \\
\text { você não falarem novamente... } \\
\text { ((a professora escreve na lousa } \\
\text { as ideias que tem que ser }\end{array}$ & $\begin{array}{c}\text { professora } \\
\text { critica } \\
\text { hipóteses }\end{array}$ & & $\begin{array}{l}\text { professora } \\
\text { apresenta } \\
\text { critérios } \\
\text { para análise } \\
\text { de hipóteses }\end{array}$ & & & $\begin{array}{c}\text { professora } \\
\text { cria } \\
\text { ferramentas } \\
\text { para } \\
\text { organizar } \\
\text { dados }\end{array}$ & $\begin{array}{l}\text { professora } \\
\text { mapeia } \\
\text { condições } \\
\text { relevantes }\end{array}$ & $\begin{array}{l}\text { professora } \\
\text { indica } \\
\text { inconsistências } \\
\text { em hipóteses }\end{array}$ \\
\hline
\end{tabular}




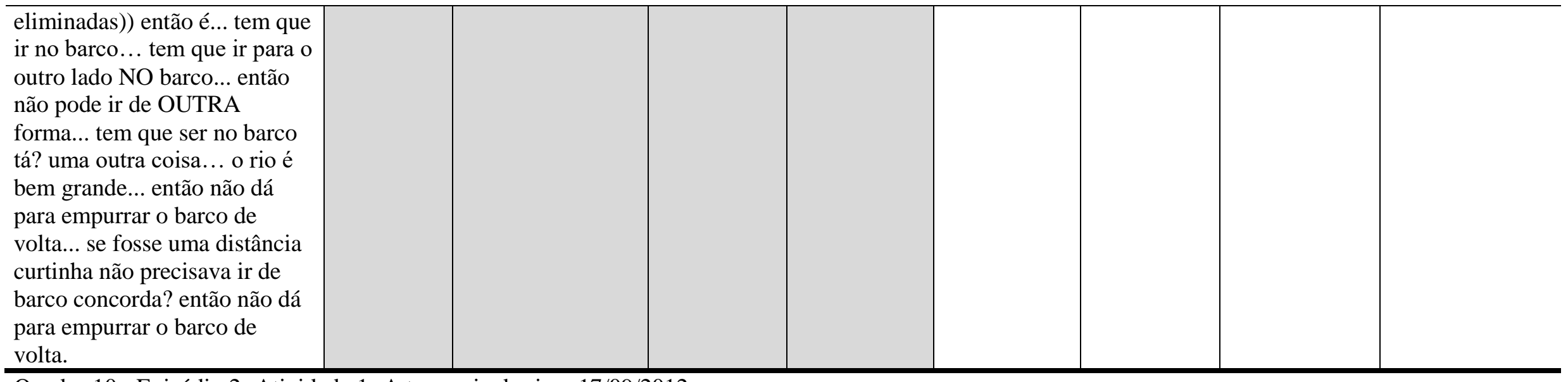

Quadro 10 - Episódio 2- Atividade 1- A travessia do rio - 17/09/2012 
Dando continuidade à análise dos processos que levaram à constituição de igualdade moderada nesta aula, neste segundo momento destacamos algumas operações da professora que estimula e reconhece as contribuições trazidas pelos estudantes, como no turno 8, ao solicitar que Joana explique melhor uma hipótese em construção, ou no turno 14, quando partilha a contribuição de Maria, ao pedir que essa repita sua hipótese para que todos possam escutar. Além dessa operação da docente, a espontaneidade com que os estudantes apresentam suas hipóteses é outra evidência de que eles são considerados e, em decorrência, se consideram capazes de contribuir. Como exemplos, um estudante não identificado (turno 11), Maria (turno 13) e Natan (turno 22) apresentam contribuições em voz alta, mesmo que não chamados pela professora.

Também caracterizando a constituição de igualdade moderada, existe outra situação como a de Fabrício (turnos 16, 29 e 42) em que o estudante levanta a mão para solicitar a palavra durante a apresentação de hipóteses pela turma. Essa é uma operação comum no contexto escolar, mas não tão frequente na aula analisada, só se repetindo com outros dois estudantes (turno 18 e 36) que, também, são chamados pela professora para contribuir. Dada essa espontaneidade com que os estudantes contribuem para construção de uma explicação coletiva, a apresentação e revisão de hipóteses acaba sendo mais marcada pela partilha de ideias do que pela moderação por uma figura de autoridade que coordene o debate e indique quando e quem pode falar.

Outra norma que se destaca ao longo deste momento diz respeito ao esclarecimento de quais critérios devem organizar e dar suporte à apresentação e à análise de novas ideias, ou seja, os padrões públicos de análise. Para estabelecimento desses critérios, ainda que todas as condições do problema tenham sido apresentadas durante a leitura do problema, a professora passa a parafrasear ou a solicitar que os estudantes repitam suas hipóteses para, a partir dessas, definir as condições da situação investigada. Isso fica mais evidente nos turnos 10, 12, 16 e 18 .

Bastante relacionada à constituição dessa norma, como operação característica da prática de planejar e executar investigações, temos o mapeamento de condições implícitas e explícitas no enunciado do problema, mas que são relevantes para construção de uma explicação. Para compreender essa relação, retomamos o turno 5, quando a professora apresenta o planejamento das etapas para execução da atividade, conforme sugerido na SEI, mas que é transformado pela sala à medida em que a professora busca estabelecer parâmetros de análise e, com isso, esclarecer para os estudantes a cena em que o problema se passa. Pelo compartilhamento das respostas em construção pelos grupos e, especificamente, pela 
indicação das condições relevantes explícitas ou implícitas no problema, temos um primeiro replanejamento que associamos ao mapeamento de variáveis relevantes, uma operação presente em comunidades científicas que precisam identificar quais variáveis são significativas para compreensão e resolução de um problema para, então, determinar como essas podem ser observadas, medidas e controladas (NRC, 2011). No problema proposto na aula em análise, as condições não podem ser modificadas, ou seja, as variáveis estão fixas, contudo, é preciso que o grupo identifique quais condições precisam ser consideradas e respeitadas na apresentação de respostas.

Durante o mapeamento das condições relevantes, a professora passa a registrar ideias a serem eliminadas (turno 12) e constrói uma lista na lousa para ajudar os estudantes na resolução do problema. Classificamos essa operação como evidência pontual da prática de análise e interpretação de dados que é comum nas comunidades científicas e pode ser caracterizada, entre outros, pela construção e adoção de ferramentas que permitam organizar dados a fim de utilizá-los como evidências para construção de uma explicação. Acreditamos que, ao adotar uma lista escrita na lousa, a professora tem a intenção de manter visível as hipóteses consideradas incoerentes para resolução do problema e, com isso, garantir que os demais grupos não precisem percorrer as mesmas ideias já invalidadas por não corresponderem às condições do problema. Todavia, essa ferramenta parece não ser adotada pela turma, como vemos no turno 17, quando Fabrício apresenta uma hipótese sustentada em uma ideia, supostamente, já eliminada e registrada na lista que é relembrada pela professora no turno seguinte. Após essa interação, não temos indicações de os estudantes utilizam a lista, de modo que propomos dizer que essa ferramenta não é assumida como parte do repertório empregado para resolução do problema.

Ainda sobre a lista, destacamos que, no momento de sua construção, além de retomar a condição inicial do problema (tem que ir para o outro lado NO barco... então não pode ir de OUTRA forma), a professora apresenta outras informações que não estão explicitadas no enunciado lido e que podem conduzir à resposta tal qual esperada na SEI. A fim de garantir a avaliação e revisão das hipóteses, ela explica que as margens do rio são distantes e que não é possível realizar a travessia a nado ou empurrando o barco. Em outros momentos da aula, essa operação reaparece quando hipóteses fiadas em uma lógica cotidiana são apresentadas pelos estudantes e a professora precisa esclarecer e reafirmar que o rio é fundo, que não existem cordas na região ou que não é viável esperar que as pessoas emagreçam a fim de não ultrapassar o limite máximo de carga. Essa recorrência de apresentação de hipóteses não sustentadas nas informações do problema, por parte dos estudantes, e o esforço em descartá- 
las, por parte da professora, evidencia um embate de forças entre esses ao buscarem encontrar juntos a resolução de um problema proposto em uma SEI que os estudantes desconhecem por completo e que a professora resiste em abandonar, a fim de promover um processo investigativo em sala.

Seguimos com mais um episódio no qual professora e estudantes buscam compreender juntos o problema a ser enfrentado. 
Indicar a necessidade de utilizar o repertório da matemática

\begin{tabular}{|c|c|c|c|c|c|c|c|}
\hline \multirow[b]{2}{*}{$\begin{array}{c}\text { Turnos } \\
\left(4{ }^{\prime} 20^{\prime \prime}-5 ' 22{ }^{\prime}\right)\end{array}$} & \multicolumn{4}{|c|}{ Evidências de Normas Culturais } & \multicolumn{3}{|c|}{ Evidências de Práticas Culturais } \\
\hline & Fórum & $\begin{array}{l}\text { Receptividade à } \\
\text { Crítica }\end{array}$ & $\begin{array}{l}\text { Padrões } \\
\text { Públicos de } \\
\text { Análise }\end{array}$ & $\begin{array}{l}\text { Igualdade } \\
\text { Moderada }\end{array}$ & $\begin{array}{c}\text { Planejar e } \\
\text { Executar } \\
\text { Investigações }\end{array}$ & $\begin{array}{c}\text { Utilizar } \\
\text { Pensamento } \\
\text { Matemático e } \\
\text { Ferramentas de } \\
\text { Informática }\end{array}$ & $\begin{array}{c}\text { Construir } \\
\text { Explicações }\end{array}$ \\
\hline $\begin{array}{l}\text { 13. Maria: Só se tivesse alguém para } \\
\text { empurrar aí pegava a gente e levava } \\
\text { depois trazia e levava }\end{array}$ & $\begin{array}{l}\text { estudantes } \\
\text { apresentam } \\
\text { hipóteses }\end{array}$ & $\begin{array}{l}\text { estudantes } \\
\text { apresentam } \\
\text { hipóteses } \\
\text { considerando } \\
\text { críticas } \\
\end{array}$ & & $\begin{array}{c}\text { estudantes } \\
\text { apresentam } \\
\text { contribuições }\end{array}$ & & & $\begin{array}{l}\text { estudantes } \\
\text { apresentam } \\
\text { hipóteses } \\
\text { coerentes }\end{array}$ \\
\hline $\begin{array}{l}\text { 14. Professora: Sim... olha aqui o que } \\
\text { a Maria falou... repete Maria... bem } \\
\text { alto }\end{array}$ & & & & $\begin{array}{l}\text { professora } \\
\text { solicita } \\
\text { contribuições } \\
\end{array}$ & & & \\
\hline $\begin{array}{l}\text { 15. Maria: Uma pessoa entrava no } \\
\text { barco para pegar uma que está desse } \\
\text { lado e levar para o outro }\end{array}$ & $\begin{array}{l}\text { estudantes } \\
\text { apresentam } \\
\text { hipóteses }\end{array}$ & $\begin{array}{l}\text { estudantes } \\
\text { apresentam } \\
\text { hipóteses } \\
\text { considerando } \\
\text { críticas } \\
\end{array}$ & & $\begin{array}{l}\text { estudantes } \\
\text { apresentam } \\
\text { contribuições }\end{array}$ & & & $\begin{array}{l}\text { estudantes } \\
\text { apresentam } \\
\text { hipóteses } \\
\text { coerentes }\end{array}$ \\
\hline $\begin{array}{l}\text { 16. Professora: Ahãn...mas não tem } \\
\text { essa pessoa tem só AS TRÊS } \\
\text { pessoas... a três estão desse lado } \\
\text { aqui do rio... as TRÊS estão ali e tem } \\
\text { que chegar do OUTRO lado do rio... } \\
\text { o barco tá parado ali tá vazio... as } \\
\text { três pessoas precisam atravessar... só } \\
\text { que o barco suporta apenas } 130 \\
\text { quilos e cada um tem } 60 \text { outro tem } \\
65 \text { e o outro tem } 80 \text { quilos tá? é isso } \\
\text { que vocês têm que pensar... } \\
\text { ((Fabrício, no grupo } 6 \text { levanta a } \\
\text { mão)) fala Fabrício! }\end{array}$ & $\begin{array}{l}\text { professora } \\
\text { critica } \\
\text { hipóteses }\end{array}$ & & $\begin{array}{l}\text { professora } \\
\text { apresenta } \\
\text { critérios para } \\
\text { análise de } \\
\text { hipóteses }\end{array}$ & $\begin{array}{c}\text { estudantes } \\
\text { solicitam } \\
\text { autorização } \\
\text { para falar } \\
\text { professora } \\
\text { solicita } \\
\text { contribuições }\end{array}$ & $\begin{array}{l}\text { professora } \\
\text { mapeia } \\
\text { condições } \\
\text { relevantes }\end{array}$ & $\begin{array}{c}\text { professora indica } \\
\text { que o problema } \\
\text { deve ser } \\
\text { respondido } \\
\text { utilizando } \\
\text { pensamento } \\
\text { matemático }\end{array}$ & $\begin{array}{l}\text { professora indica } \\
\text { inconsistências } \\
\text { em hipóteses }\end{array}$ \\
\hline
\end{tabular}

Quadro 11 - Episódio 3- Atividade 1- A travessia do rio - 17/09/2012 
Com esse episódio, destacamos uma sequência de operações da professora (turno 16) para indicar o que parece não ter sido assimilado pela turma "o barco suporta apenas 130 quilos e cada um tem 60 outro tem 65 e o outro tem 80 quilos tá? é isso que vocês têm que pensar", ou seja, e necessário o uso do pensamento matemático para resolução do problema. Essa necessidade não é afirmada pela professora em nenhum momento da aula, mas indicada pela entonação no turno 5 e, nesse episódio, pela retomada dos dados numéricos do enunciado durante a indicação das inconsistências na hipótese de Maria.

Aproveitamos esse turno para justificar, também, nossa opção por não categorizar perguntas retóricas como as apresentadas nos turnos 12 e 16 como operações características da prática de fazer perguntas. Conforme discutido por Machado (2012, p. 21) a pergunta é um “instrumento dialógico de estímulo à cadeia enunciativa. Sendo assim usado com propósito didático dentro da estória da sala de aula para traçar e acompanhar a construção de um significado e um conceito", podendo aparecer, entre outros, com o propósito de problematizar um tema, explorar ideias ou processos, sistematizar assuntos trabalhadas ou questionar sobre dados, o que não ocorre quando a professora introduz um "tá?" em sua fala, compreendido, neste trabalho, mais como uma marca da oralidade do que como um estímulo à cadeia enunciativa.

Nas comunidades científicas, as perguntas podem ser formuladas com diferentes finalidades, tais como, identificar o que já é conhecido na área, guiar a construção de novas respostas explicativas ou colocar ideias em teste (NRC, 2011). De modo similar, ao longo do segundo momento dessa aula, podemos identificar operações que evidenciam a prática de fazer perguntas em turnos da professora, como o 8 e o 20, nos quais são formuladas perguntas que ajudam os estudantes a construir uma explicação por meio de uma maior elaboração das hipóteses apresentadas. Já na voz dos estudantes, as perguntas aparecem como meio de colocar uma hipótese em teste, sendo para verificar sua consistência junto à professora (turno 17) ou problematizar o proposto por outro estudante, como faz Natan em relação à hipótese de Ariel no turno 23.

Na sequência, temos o último episódio desse momento, no qual os estudantes já estão mais próximos do entendimento do problema proposto. 
Revisar ideias coletivamente

\begin{tabular}{|c|c|c|c|c|c|c|c|}
\hline \multirow[b]{2}{*}{$\begin{array}{c}\text { Turnos } \\
\left(5^{\prime} 23^{\prime},-53^{\prime}, 3^{\prime}\right)\end{array}$} & \multicolumn{4}{|c|}{ Evidências de Normas Culturais } & \multicolumn{3}{|c|}{ Evidências de Práticas Culturais } \\
\hline & Fórum & $\begin{array}{c}\text { Receptividade à } \\
\text { Crítica }\end{array}$ & $\begin{array}{c}\text { Padrões } \\
\text { Públicos de } \\
\text { Análise } \\
\end{array}$ & $\begin{array}{l}\text { Igualdade } \\
\text { Moderada }\end{array}$ & Fazer Perguntas & $\begin{array}{c}\text { Planejar e } \\
\text { Executar } \\
\text { Investigações }\end{array}$ & $\begin{array}{c}\text { Construir } \\
\text { Explicações }\end{array}$ \\
\hline $\begin{array}{l}\text { 17. Fabrício: E se colocasse uma } \\
\text { corda no barco? um vai lá... vai } \\
\text { o outro e puxa o barco }\end{array}$ & $\begin{array}{l}\text { estudantes } \\
\text { apresentam } \\
\text { hipóteses }\end{array}$ & $\begin{array}{c}\text { estudantes } \\
\text { apresentam } \\
\text { hipóteses } \\
\text { desconsiderando } \\
\text { críticas }\end{array}$ & & $\begin{array}{c}\text { estudantes } \\
\text { apresentam } \\
\text { contribuições }\end{array}$ & $\begin{array}{l}\text { estudantes } \\
\text { fazem } \\
\text { perguntas para } \\
\text { testar hipóteses }\end{array}$ & & $\begin{array}{l}\text { estudantes } \\
\text { apresentam } \\
\text { hipóteses } \\
\text { incoerentes }\end{array}$ \\
\hline $\begin{array}{l}\text { 18. Professora: Não... essa ideia } \\
\text { também não dá... por que não } \\
\text { tem corda... só tem o barco e o } \\
\text { rio é bem grande ((professora } \\
\text { aponta para as anotações na } \\
\text { lousa)) lembra que eu já falei } \\
\text { ((Ariel, no grupo } 5 \text { levanta a } \\
\text { mão e a professora aponta para } \\
\text { ele)) }\end{array}$ & $\begin{array}{l}\text { professora } \\
\text { critica } \\
\text { hipóteses }\end{array}$ & & $\begin{array}{l}\text { professora } \\
\text { apresenta } \\
\text { critérios para } \\
\text { análise de } \\
\text { hipóteses }\end{array}$ & $\begin{array}{c}\text { estudantes } \\
\text { solicitam } \\
\text { autorização } \\
\text { para fala } \\
\text { professora } \\
\text { solicita } \\
\text { contribuições }\end{array}$ & & $\begin{array}{l}\text { professora } \\
\text { mapeia } \\
\text { condições } \\
\text { relevantes }\end{array}$ & $\begin{array}{l}\text { professora indica } \\
\text { inconsistências } \\
\text { em hipóteses }\end{array}$ \\
\hline 19. Ariel: Vai um de cada vez... & $\begin{array}{l}\text { estudantes } \\
\text { apresentam } \\
\text { hipóteses }\end{array}$ & $\begin{array}{c}\text { estudantes } \\
\text { apresentam } \\
\text { hipóteses } \\
\text { considerando } \\
\text { críticas } \\
\end{array}$ & & $\begin{array}{c}\text { estudantes } \\
\text { apresentam } \\
\text { contribuições }\end{array}$ & & & $\begin{array}{l}\text { estudantes } \\
\text { apresentam } \\
\text { hipóteses } \\
\text { coerentes }\end{array}$ \\
\hline $\begin{array}{l}\text { 20. Professora: Um de cada vez? } \\
\text { me explica melhor como é que é } \\
\text { isso }\end{array}$ & $\begin{array}{l}\text { professora } \\
\text { critica } \\
\text { hipóteses }\end{array}$ & & & $\begin{array}{l}\text { professora } \\
\text { solicita } \\
\text { contribuições }\end{array}$ & $\begin{array}{c}\text { professora faz } \\
\text { perguntas para } \\
\text { guiar a } \\
\text { construção de } \\
\text { explicações }\end{array}$ & & $\begin{array}{l}\text { professora solicita } \\
\text { que estudantes } \\
\text { revisem hipóteses }\end{array}$ \\
\hline \multicolumn{8}{|l|}{ 21. Ariel: Vai (inaudível) } \\
\hline $\begin{array}{l}\text { 22. Professora: Peraí... o::: } \\
\text { escuta isso aqui ((professora } \\
\text { aponta para Natan no grupo 2)) } \\
\text { fala bem alto o que você falou }\end{array}$ & & & & $\begin{array}{c}\text { professora } \\
\text { solicita } \\
\text { contribuições }\end{array}$ & & & \\
\hline
\end{tabular}




\begin{tabular}{|c|c|c|c|c|c|}
\hline $\begin{array}{l}\text { 23. Natan: Como é que você vai } \\
\text { trazer o barco de volta? }\end{array}$ & $\begin{array}{l}\text { estudantes } \\
\text { criticam } \\
\text { hipóteses }\end{array}$ & $\begin{array}{c}\text { estudantes } \\
\text { apresentam } \\
\text { contribuições }\end{array}$ & $\begin{array}{c}\text { estudantes } \\
\text { fazem } \\
\text { perguntas para } \\
\text { testar hipóteses }\end{array}$ & $\begin{array}{l}\text { estudantes } \\
\text { mapeiam } \\
\text { condições } \\
\text { relevantes }\end{array}$ & $\begin{array}{c}\text { estudantes } \\
\text { indicam } \\
\text { inconsistências } \\
\text { em hipóteses }\end{array}$ \\
\hline
\end{tabular}

Quadro 12 - Episódio 4- Atividade 1- A travessia do rio - 17/09/2012 
Nos três episódios que compõem esse momento, destacamos algumas operações dos estudantes e da professora que acreditamos cooperar para configuração da sala de aula como um fórum, um espaço de apresentação, análise e revisão de hipóteses que respondam ao problema proposto. Falamos aqui de interações como a que ocorre entre os turnos 8 e 11, quando a professora solicita a Joana que elabore uma hipótese que é, em seguida, criticada pela professora e revisada por outro estudante. Esse padrão se repete entre os turnos 15 e 17 com a apresentação de uma ideia por Maria que é criticada pela professora e revisada por Fabrício, seguindo, portanto, com a mesma estrutura de envolvimento de estudantes diferentes na apresentação e na revisão de hipótese e da professora como quem avalia as ideias apresentadas.

Esse padrão poderia, à primeira vista, ser compreendido como uma interação tradicional do tipo Iniciação-Resposta-Avaliação (MEHAN, 1979), todavia, observando as colunas referentes à receptividade à crítica, encontramos algumas evidências de que esse movimento não conduzirá a uma interação tradicional, mas à construção de explicações cada vez mais elaboradas e justificadas. Como exemplo, ao apresentar sua hipótese, Maria (turno 13) acolhe os critérios que haviam sido apresentados pela professora e propõe uma solução na qual a travessia é realizada no barco, respeitando a distância entre as margens do rio. Nessa hipótese, ainda que apresente inconsistências ao prever a presença de uma quarta pessoa, a estudante incorpora críticas e revisa ideias de outros colegas.

Neste episódio específico, como exemplo da constituição da norma de fórum que reforça nossa análise de que as interações ocorridas nessa turma não podem ser vistas como tradicionais, temos um diálogo envolvendo estudantes de três grupos distintos e que assumimos com evidência de que, ao longo do segundo momento, as ideias são apresentadas e revisadas coletivamente por toda sala. Iniciando essa interação, no turno 17, Fabrício verifica uma possibilidade de explicação junto à professora. Nessa possibilidade, a crítica de que as margens são muitos distantes é desconsiderada e o estudante segue preso à lógica cotidiana, sugerindo a introdução de novos elementos à cena. Ao avaliar essa possível explicação, a professora evidencia sua limitação, reforçando que naquela situação só existem o barco e as três pessoas, o que exclui a possibilidade de utilização de uma corda.

A partir dessa avaliação, Ariel (turno 19), em outro grupo, apresenta uma nova hipótese, propondo que "vai um de cada vez". Ao ouvir uma proposta que admite a possibilidade de o barco fazer várias viagens entre uma margem e outra e que, portanto, aproxima-se da resolução esperada na SEI, a professora tenta elaborar uma explicação com o estudante (turno 20), mas essa logo é criticada por Natan (turno 23) numa operação que, pela 
primeira vez nessa aula, posiciona um estudante no papel de avaliador ao fazer uma pergunta que coloca a hipótese de Ariel em teste e mapeia uma condição relevante para construção do plano de investigação.

Identificamos nesse ponto uma nova norma, diferente daquela constantemente vista nas aulas tradicionais ou mesmo do que vinha se estabelecendo na turma: ao avaliar a hipótese em construção por outro colega, Natan assume autoridade epistêmica e podemos ver, em sala, algo parecido com a avaliação entre pares, comum em comunidades científicas, evidenciando a constituição de igualdade moderada de participação naquela sala. Uma vez havendo essa igualdade relativizada por níveis de expertise ou conhecimento, mas não por uma relação vertical de poder, Natan teve espaço para tecer uma avaliação.

Iniciado e conduzido por questionamento de estudantes, esse episódio parece evidenciar que algumas normas culturais semelhantes àquelas das comunidades científicas se estabelecem nessa sala pela opção da professora de estimular as contribuições dos estudantes, mas também pela postura desses que recebem as hipóteses apresentadas por seus colegas e passam a revisar explicações a partir delas.

Conforme Wenger (2016) para constituição de uma comunidade de práticas é fundamental que os envolvidos em um empreendimento tenham meios e espaços de interação nos quais seja garantida a participação coletiva. Tendo em vista a análise acima, acreditamos que esse engajamento mútuo parece se delinear à medida em que fórum, igualdade moderada e receptividade à crítica se estabelecem como norma nessa sala. Nesse sentido, compreendemos que as contribuições colaborativas que são feitas por diferentes estudantes, o reconhecimento e estímulo à participação de todos e a revisão de hipóteses sustentada pelas críticas feitas pela professora são indicativos, ainda que não suficientes, de que essa sala, ao menos durante esse momento, pode ser compreendida como uma comunidade de práticas, na qual há engajamento mútuo dos membros para realização de um empreendimento negociado (problema) à medida em que algumas ideias são, coletivamente, revisadas.

Mudando o foco de análise para as práticas, destacamos algumas operações que evidenciam a construção de explicações como prática dessa sala. Como exemplo disso, logo no início do segundo momento, vemos a professora incentivar Joana a elaborar uma explicação que pôde ouvir ao passar pelos grupos. Naquele episódio, ao apresentar sua hipótese, Joana (turno 9) constrói uma explicação que não atende ao esperado na SEI, mas que classificamos como coerente, pois organiza as evidências disponíveis e incorpora a compreensão corrente que a turma tem sobre o fenômeno em estudo, estando pautada, não em uma lógica matemática, mas em explicações cotidianas. Frente a essa explicação, a professora 
repete a hipótese em voz alta e a avalia para que toda a turma possa ouvir, evidenciando suas inconsistências e apresentando uma condição relevante para execução da investigação e que não estava explícita no enunciado do problema: "a distância é muito grande e não dá para empurrar o barco de volta".

A partir da avaliação da professora, outro estudante (turno 11) revisa a ideia anterior, apresentando uma hipótese que classificamos como incoerente pois desconsidera o critério recém apresentado de que a distância entre as margens é muito grande inviabilizando a travessia a nado. Nesse turno, compreendemos que a receptividade à crítica ainda não pode ser considerada como uma norma, uma vez que essa engloba, o acolhimento das críticas às explicações apresentadas, mas também a revisão das explicações a partir dessas, o que não parece ocorrer. Já no episódio três, como anteriormente discutido, Maria apresenta uma hipótese coerente com as críticas já realizadas, mas que ainda apresenta inconsistências, como apontada pela professora. De modo similar, no episódio 4, Ariel apresenta uma hipótese coerente com o já estabelecido no grupo, mas que ainda apresenta inconsistências que são apontadas por Natan. A espontaneidade com que a crítica de Natan é apresentada e acolhida, independente de solicitação da docente, é analisada como outra evidência de que, nesse momento, a sala se configura como um fórum.

Conforme as hipóteses em elaboração passam a ser partilhadas e avaliadas por toda sala, temos outra metamorfose na proposta de que, somente, as explicações já validadas por cada um dos grupos fossem comunicadas e comparadas, ao final da aula, o que caracteriza a construção de explicações, durante a realização dessa atividade, como uma prática coletiva.

Com esse episódio, encerramos o segundo momento da aula que é marcado pela transição entre a resolução em pequenos grupos (proposta na SEI) e o enfrentamento coletivo do problema (estabelecido pela sala), o que parece ter permitido aos estudantes partilharem hipóteses inicias e, pelas intervenções da professora e colegas de sala, identificar suas inconsistências, conduzindo, como veremos no momento que segue, à utilização do repertório da matemática para enfrentamento do problema.

A condução desse momento intermediário de entendimento do problema é aqui compreendida como uma importante intervenção da professora, pois parece ter auxiliado o grupo num processo que, conforme Borges (2002, p. 24), é um dos mais complexos nas atividades investigativas, de modo que, por vezes, os estudantes "só conseguem entender o que devem fazer e formular o problema de forma mais ou menos clara, depois de passar várias vezes pelas mesmas etapas". 


\subsubsection{O enfrentamento coletivo do problema}

No período que definimos como o terceiro momento de aula, aqui retratado por três episódios, as normas culturais para construção de uma explicação que vinham se construindo mostram-se mais presentes em comparação com os outros dois momentos e, conforme os estudantes aproximam-se da resposta esperada, a professora segue comunicando algumas das hipóteses e propondo perguntas que, por relembrarem a todo tempo os dados do problema, evitam que alguma variável seja desconsiderada e criam um espaço de livre apresentação e revisão de hipóteses para construção de uma explicação coletiva pela turma. 
Destacar uma resposta parcial

\begin{tabular}{|c|c|c|c|c|c|c|c|c|}
\hline \multirow[b]{2}{*}{$\begin{array}{r}\text { Turnos } \\
\left(66^{\prime} 58^{\prime},-78^{\prime \prime}\right)\end{array}$} & \multicolumn{4}{|c|}{ Evidências de Normas Culturais } & \multicolumn{4}{|c|}{ Evidências de Práticas Culturais } \\
\hline & Fórum & $\begin{array}{l}\text { Receptividade } \\
\text { à Crítica }\end{array}$ & $\begin{array}{l}\text { Padrões } \\
\text { Públicos de } \\
\text { Análise }\end{array}$ & $\begin{array}{l}\text { Igualdade } \\
\text { Moderada }\end{array}$ & $\begin{array}{c}\text { Planejar e } \\
\text { Executar } \\
\text { Investigações }\end{array}$ & $\begin{array}{c}\text { Utilizar } \\
\text { Pensamento } \\
\text { Matemático e } \\
\text { Ferramentas } \\
\text { de Informática } \\
\end{array}$ & $\begin{array}{l}\text { Construir } \\
\text { Explicações }\end{array}$ & $\begin{array}{l}\text { Engajar-se em } \\
\text { Argumentações } \\
\text { Baseadas em } \\
\text { Evidências }\end{array}$ \\
\hline $\begin{array}{l}\text { 35. Fabrício: Um dos } \\
\text { amigos vai... deixa um } \\
\text { lá pega o outro e volta }\end{array}$ & $\begin{array}{c}\text { estudantes } \\
\text { apresentam } \\
\text { hipóteses }\end{array}$ & $\begin{array}{l}\text { estudantes } \\
\text { apresentam } \\
\text { hipóteses } \\
\text { considerando } \\
\text { críticas }\end{array}$ & & $\begin{array}{c}\text { estudantes } \\
\text { apresentam } \\
\text { contribuições }\end{array}$ & & & $\begin{array}{l}\text { estudantes } \\
\text { apresentam } \\
\text { hipóteses } \\
\text { coerentes }\end{array}$ & \\
\hline $\begin{array}{l}\text { 36. Professora: Sim isso } \\
\text { é legal, só que cê tem } \\
\text { que pensar em uma } \\
\text { coisa... o barco só } \\
\text { comporta } 130 \text { quilos... } \\
\text { e aí um tem } 60 \text { o outro } \\
\text { tem } 65 \text { e outro tem } 80 \\
\text { quilos ((Diego no grupo } \\
3 \text { levanta a mão e a } \\
\text { professora aponta para } \\
\text { ele, mas o grupo } \\
\text { continua conversando)) } \\
\text { peraí... peraí }\end{array}$ & $\begin{array}{l}\text { professora } \\
\text { critica } \\
\text { hipóteses }\end{array}$ & & $\begin{array}{c}\text { professora } \\
\text { retoma } \\
\text { critérios já } \\
\text { estabelecidos } \\
\text { para análise de } \\
\text { hipóteses }\end{array}$ & $\begin{array}{l}\text { estudantes } \\
\text { solicitam } \\
\text { autorização } \\
\text { para falar } \\
\text { professora } \\
\text { solicita } \\
\text { contribuições }\end{array}$ & $\begin{array}{l}\text { professora } \\
\text { mapeia } \\
\text { condições } \\
\text { relevantes }\end{array}$ & $\begin{array}{l}\text { professora } \\
\text { solicita que } \\
\text { estudantes } \\
\text { revisem } \\
\text { hipóteses } \\
\text { utilizando } \\
\text { pensamento } \\
\text { matemático }\end{array}$ & $\begin{array}{c}\text { professora } \\
\text { indica } \\
\text { inconsistências } \\
\text { em hipóteses }\end{array}$ & $\begin{array}{c}\text { professora solicita } \\
\text { que estudantes } \\
\text { defendam } \\
\text { hipóteses } \\
\text { baseando-se em } \\
\text { informações do } \\
\text { problema }\end{array}$ \\
\hline $\begin{array}{l}\text { 37. Diego: Então vai } \\
\text { dois em um barco só } \\
\text { um de } 60 \text { e } 65 \\
\text { (inaudível) }\end{array}$ & $\begin{array}{l}\text { estudantes } \\
\text { revisam } \\
\text { hipóteses }\end{array}$ & $\begin{array}{l}\text { estudantes } \\
\text { revisam } \\
\text { hipóteses } \\
\text { considerando } \\
\text { críticas }\end{array}$ & & $\begin{array}{l}\text { estudantes } \\
\text { apresentam } \\
\text { contribuições }\end{array}$ & & $\begin{array}{l}\text { estudantes } \\
\text { revisam } \\
\text { hipóteses } \\
\text { utilizando } \\
\text { pensamento } \\
\text { matemático }\end{array}$ & $\begin{array}{l}\text { estudantes } \\
\text { apresentam } \\
\text { hipóteses } \\
\text { coerentes }\end{array}$ & $\begin{array}{c}\text { estudantes } \\
\text { defendem } \\
\text { hipóteses } \\
\text { baseando-se em } \\
\text { informações do } \\
\text { problema }\end{array}$ \\
\hline
\end{tabular}

Quadro 13 - Episódio 5- Atividade 1- A travessia do rio - 17/09/2012 
Iniciamos a análise do terceiro momento enfocando uma prática que, mesmo que indicada na SEI, ainda não havia se manifestado nas operações dos estudantes: a utilização de pensamento matemático. Ainda que, implicitamente, o enunciado conduzisse a uma resolução baseada na lógica matemática, ao se deparar com o problema, a turma não lança mão do repertório da matemática e busca soluções envolvendo elementos que, como buscou evidenciar a professora, não estavam disponíveis no cenário do problema. Entretanto, na medida em que o problema é mais bem entendido, Fabrício apresenta uma hipótese que é elaborada coletivamente e justificada pelos dados numéricos do problema.

Logo no início do episódio acima, Fabrício (turno 35) apresenta uma hipótese que é identificada pela professora e então repetida por duas vezes até que seja ouvida por toda a turma "um dos amigos vai... deixa um lá pega o outro e volta". Em sua hipótese, Fabrício traz a ideia central para resolução do problema, contudo, ainda não elaborada e justificada pelo uso do repertório da matemática. A fim de conduzir a elaboração dessa hipótese, a professora retoma os dados do problema e, em seguida, Diego apresenta (turno 37) uma explicação parcial para o problema "vai dois em um barco só um de 60 e 65 ".

Ao contrário do que vimos até então, nesse momento, os estudantes apresentam uma hipótese utilizando pensamento e repertório matemático, o que é respondido pela professora com a solicitação de elaborações, justificativas e críticas que articulem esse repertório, o que é feito coletivamente ao longo deste terceiro momento como, por exemplo, entre os turnos 75 e 81, quando Manoel retoma a hipótese de Diego e, então, propõe a hipótese de que "o de 60 pega o de 80", sendo, prontamente, questionado por um estudante (turno 82) e, em seguida, pela sala que, entre os turnos 83 e 86 aponta inconsistências no cálculo, uma vez que, seguindo a hipótese de Manoel, a carga chegaria a 140 quilos, ultrapassando o limite do barco.

Observamos emergir, juntamente com o uso do pensamento matemático, a prática de argumentação não baseada em evidências, mas em informações do problema. Compreendendo, como afirmam Gonzalez-Howard e McNeill (2016, p. 529), que não existe um consenso sobre a definição da argumentação científica ou de como essa deve acontecer em sala de aula, neste terceiro momento, percebemos a argumentação a partir da interpretação de que,

em uma sala de aula de ciências, isso [argumentação] deve incluir o professor criando oportunidades para que os estudantes articulem, por meio da escrita ou conversa, sua compreensão de um tópico. Ao tornar seu pensamento visível para os colegas, outros estudantes podem então desafiar, questionar ou construir sobre esses entendimentos. Através de tais ações, a classe desenvolve uma compreensão mais clara da ciência. 
Acreditamos que essa interpretação da argumentação como um processo coletivo de apresentação e questionamento de entendimentos pode ser exemplificada na operação de Diego (turno 37) que defende uma proposição apresentada por Fabrício ao revisá-la a partir de dados do problema, ou na operação da professora que, entre os turnos 75 e 86, cria oportunidades para que os estudantes articulem por meio de perguntas um argumento que é, momentos depois, sintetizado por Fabrício, no turno 123, ao sintetizar o entendimento de que "se o de 60 fosse buscar o de $65 \ldots$ ia dar 125 ai não ia dar porque o de 65 não tem como buscar o de $80 "$. 
Desenvolver, coletivamente, uma resposta parcial

\begin{tabular}{|c|c|c|c|c|c|c|c|c|}
\hline \multirow[b]{2}{*}{$\begin{array}{l}\text { Turnos } \\
(11 \text { '27"'- } \\
12 \text { '15') }\end{array}$} & \multicolumn{4}{|c|}{ Evidências de Normas Culturais } & \multicolumn{4}{|c|}{ Evidências de Práticas Culturais } \\
\hline & Fórum & $\begin{array}{l}\text { Receptividade à } \\
\text { Crítica }\end{array}$ & $\begin{array}{l}\text { Padrões } \\
\text { Públicos de } \\
\text { Análise }\end{array}$ & $\begin{array}{l}\text { Igualdade } \\
\text { Moderada }\end{array}$ & $\begin{array}{c}\text { Fazer } \\
\text { Perguntas }\end{array}$ & $\begin{array}{c}\text { Utilizar } \\
\text { Pensamento } \\
\text { Matemático e } \\
\text { Ferramentas de } \\
\text { Informática }\end{array}$ & $\begin{array}{l}\text { Construir } \\
\text { Explicações }\end{array}$ & $\begin{array}{l}\text { Engajar-se em } \\
\text { Argumentações } \\
\text { Baseadas em } \\
\text { Evidências }\end{array}$ \\
\hline $\begin{array}{l}\text { 73. Professora: } \\
\text { E aí Manoel, } \\
\text { você não falou } \\
\text { nada hoje! }\end{array}$ & & & & $\begin{array}{c}\text { professora } \\
\text { solicita } \\
\text { contribuiçõos }\end{array}$ & & & $\begin{array}{l}\text { professora } \\
\text { solicita que } \\
\text { estudantes } \\
\text { apresentem } \\
\text { hipóteses }\end{array}$ & \\
\hline $\begin{array}{l}\text { 74. Manoel: } \\
\text { (inaudível) } \\
\text { Dois vai... } \\
\text { deixa um e } \\
\text { pega outro... }\end{array}$ & $\begin{array}{l}\text { estudantes } \\
\text { apresentam } \\
\text { hipóteses }\end{array}$ & $\begin{array}{l}\text { estudantes } \\
\text { apresentam } \\
\text { hipóteses } \\
\text { considerando } \\
\text { críticas } \\
\end{array}$ & & $\begin{array}{c}\text { estudantes } \\
\text { apresentam } \\
\text { contribuições }\end{array}$ & & & $\begin{array}{l}\text { estudantes } \\
\text { apresentam } \\
\text { hipóteses } \\
\text { coerentes }\end{array}$ & \\
\hline $\begin{array}{l}\text { 75. Professora: } \\
\text { Mas quem são } \\
\text { os dois que } \\
\text { vão? }\end{array}$ & $\begin{array}{l}\text { professora } \\
\text { critica } \\
\text { hipóteses }\end{array}$ & & & $\begin{array}{c}\text { professora } \\
\text { solicita } \\
\text { contribuições }\end{array}$ & $\begin{array}{c}\text { professora faz } \\
\text { perguntas para } \\
\text { guiar a } \\
\text { construção de } \\
\text { explicações }\end{array}$ & $\begin{array}{l}\text { professora } \\
\text { solicita que } \\
\text { estudantes } \\
\text { revisem } \\
\text { hipóteses } \\
\text { utilizando } \\
\text { pensamento } \\
\text { matemático }\end{array}$ & $\begin{array}{l}\text { professora } \\
\text { solicita que } \\
\text { estudantes } \\
\text { revisem } \\
\text { hipóteses }\end{array}$ & $\begin{array}{c}\text { professora solicita } \\
\text { que estudantes } \\
\text { defendam hipóteses } \\
\text { baseando-se em } \\
\text { informações do } \\
\text { problema }\end{array}$ \\
\hline $\begin{array}{l}\text { 76. Manoel: } O \\
\text { de } 60 \text { e o de } \\
65 .\end{array}$ & $\begin{array}{l}\text { estudantes } \\
\text { revisam } \\
\text { hipóteses }\end{array}$ & $\begin{array}{l}\text { estudantes } \\
\text { revisam } \\
\text { hipóteses } \\
\text { considerando } \\
\text { críticas }\end{array}$ & & $\begin{array}{c}\text { estudantes } \\
\text { apresentam } \\
\text { contribuições }\end{array}$ & & $\begin{array}{l}\text { estudantes } \\
\text { revisam } \\
\text { hipóteses } \\
\text { utilizando } \\
\text { pensamento } \\
\text { matemático }\end{array}$ & $\begin{array}{l}\text { estudantes } \\
\text { apresentam } \\
\text { revisões } \\
\text { coerentes }\end{array}$ & $\begin{array}{c}\text { estudantes } \\
\text { defendem hipóteses } \\
\text { baseando-se em } \\
\text { informações do } \\
\text { problema }\end{array}$ \\
\hline
\end{tabular}




\begin{tabular}{|c|c|c|c|c|c|c|c|}
\hline $\begin{array}{l}\text { 77. Professora: } \\
\text { Tá... o de } 60 \text { e } \\
\text { o de } 65 \text { pode ir } \\
\text { e vai dar } \\
\text { quanto? }\end{array}$ & $\begin{array}{l}\text { professora } \\
\text { critica } \\
\text { hipóteses }\end{array}$ & & $\begin{array}{c}\text { professora } \\
\text { solicita } \\
\text { contribuições }\end{array}$ & $\begin{array}{c}\text { professora faz } \\
\text { perguntas para } \\
\text { guiar a } \\
\text { construção de } \\
\text { explicações }\end{array}$ & $\begin{array}{c}\text { professora } \\
\text { solicita que } \\
\text { estudantes } \\
\text { justifiquem } \\
\text { hipóteses } \\
\text { utilizando } \\
\text { pensamento } \\
\text { matemático }\end{array}$ & $\begin{array}{l}\text { professora } \\
\text { solicita que } \\
\text { estudantes } \\
\text { justifiquem } \\
\text { hipóteses }\end{array}$ & $\begin{array}{l}\text { professora solicita } \\
\text { que estudantes } \\
\text { defendam hipóteses } \\
\text { baseando-se em } \\
\text { informações do } \\
\text { problema }\end{array}$ \\
\hline $\begin{array}{l}\text { 78. Manoel: } \\
125\end{array}$ & $\begin{array}{l}\text { estudantes } \\
\text { justificam } \\
\text { hipóteses }\end{array}$ & & $\begin{array}{c}\text { estudantes } \\
\text { apresentam } \\
\text { contribuições }\end{array}$ & & $\begin{array}{l}\text { estudante } \\
\text { justificam } \\
\text { hipóteses } \\
\text { utilizando } \\
\text { pensamento } \\
\text { matemático }\end{array}$ & $\begin{array}{c}\text { estudantes } \\
\text { apresentam } \\
\text { justificativas } \\
\text { coerentes }\end{array}$ & $\begin{array}{c}\text { estudantes } \\
\text { defendem hipóteses } \\
\text { baseando-se em } \\
\text { informações do } \\
\text { problema }\end{array}$ \\
\hline $\begin{array}{l}\text { 79. Professora: } \\
\text { Aí eles podem } \\
\text { ir.... tá bom... } \\
\text { mas e aí quem } \\
\text { é que volta? }\end{array}$ & $\begin{array}{l}\text { professora } \\
\text { critica } \\
\text { hipóteses }\end{array}$ & & $\begin{array}{c}\text { professora } \\
\text { solicita } \\
\text { contribuições }\end{array}$ & $\begin{array}{l}\text { professora faz } \\
\text { perguntas para } \\
\text { guiar a } \\
\text { construção de } \\
\text { explicações }\end{array}$ & $\begin{array}{c}\text { professora } \\
\text { solicita que } \\
\text { estudantes } \\
\text { apresentem } \\
\text { hipóteses } \\
\text { utilizando } \\
\text { pensamento } \\
\text { matemático }\end{array}$ & $\begin{array}{l}\text { professora } \\
\text { solicita que } \\
\text { estudantes } \\
\text { apresentem } \\
\text { hipóteses }\end{array}$ & $\begin{array}{l}\text { professora solicita } \\
\text { que estudantes } \\
\text { avancem com } \\
\text { hipóteses baseando- } \\
\text { se em informações } \\
\text { do problema }\end{array}$ \\
\hline $\begin{array}{l}\text { 80. Manoel: } O \\
\text { de } 60 \text { pega o de } \\
80\end{array}$ & $\begin{array}{l}\text { estudantes } \\
\text { apresentam } \\
\text { hipóteses }\end{array}$ & $\begin{array}{l}\text { estudantes } \\
\text { apresentam } \\
\text { hipóteses } \\
\text { considerando } \\
\text { críticas }\end{array}$ & $\begin{array}{c}\text { estudantes } \\
\text { apresentam } \\
\text { contribuições }\end{array}$ & & $\begin{array}{c}\text { estudantes } \\
\text { apresentam } \\
\text { hipóteses } \\
\text { utilizando } \\
\text { pensamento } \\
\text { matemático }\end{array}$ & $\begin{array}{l}\text { estudantes } \\
\text { apresentam } \\
\text { hipóteses } \\
\text { coerentes }\end{array}$ & $\begin{array}{l}\text { estudantes avançam } \\
\text { hipóteses baseando- } \\
\text { se em informações } \\
\text { do problema }\end{array}$ \\
\hline $\begin{array}{l}\text { 81. Professora: } \\
\text { E o de } 60 \text { com } \\
\text { o de } 80 \ldots \text { eles } \\
\text { podem estar no } \\
\text { barco os dois? }\end{array}$ & $\begin{array}{l}\text { professora } \\
\text { critica } \\
\text { hipóteses }\end{array}$ & & $\begin{array}{c}\text { professora } \\
\text { solicita } \\
\text { contribuições }\end{array}$ & $\begin{array}{c}\text { professora faz } \\
\text { perguntas para } \\
\text { testar } \\
\text { hipóteses }\end{array}$ & $\begin{array}{c}\text { professora } \\
\text { solicita que } \\
\text { estudantes } \\
\text { justifiquem } \\
\text { hipóteses } \\
\text { utilizando }\end{array}$ & $\begin{array}{l}\text { professora } \\
\text { solicita que } \\
\text { estudantes } \\
\text { justifiquem } \\
\text { hipóteses }\end{array}$ & $\begin{array}{l}\text { professora solicita } \\
\text { que estudantes } \\
\text { defendam hipóteses } \\
\text { baseando-se em } \\
\text { informações do } \\
\text { problema }\end{array}$ \\
\hline
\end{tabular}




\begin{tabular}{|c|c|c|c|c|c|c|c|}
\hline & & & & & $\begin{array}{l}\text { pensamento } \\
\text { matemático }\end{array}$ & & \\
\hline $\begin{array}{l}\text { 82. Estudante: } \\
\text { Não vai dá } \\
\text { professora. }\end{array}$ & $\begin{array}{l}\text { estudantes } \\
\text { revisam } \\
\text { hipóteses }\end{array}$ & & $\begin{array}{c}\text { estudantes } \\
\text { apresentam } \\
\text { contribuições }\end{array}$ & & & $\begin{array}{c}\text { estudantes } \\
\text { indicam } \\
\text { inconsistências } \\
\text { em hipóteses }\end{array}$ & $\begin{array}{l}\text { estudantes criticam } \\
\text { hipóteses baseando- } \\
\text { se em informações } \\
\text { do problema }\end{array}$ \\
\hline $\begin{array}{l}\text { 83. Professora: } \\
\text { Por que vai dá? } \\
\text { ((apontando } \\
\text { para } \\
\text { estudante)) }\end{array}$ & $\begin{array}{l}\text { professora } \\
\text { critica } \\
\text { hipóteses }\end{array}$ & & $\begin{array}{c}\text { professora } \\
\text { solicita } \\
\text { contribuições }\end{array}$ & $\begin{array}{l}\text { professora faz } \\
\text { perguntas para } \\
\text { guiar a } \\
\text { construção de } \\
\text { explicações }\end{array}$ & $\begin{array}{c}\text { professora } \\
\text { solicita que } \\
\text { estudantes } \\
\text { justifiquem } \\
\text { hipóteses } \\
\text { utilizando } \\
\text { pensamento } \\
\text { matemático }\end{array}$ & $\begin{array}{l}\text { professora } \\
\text { solicita que } \\
\text { estudantes } \\
\text { justifiquem } \\
\text { hipóteses }\end{array}$ & $\begin{array}{c}\text { professora solicita } \\
\text { que estudantes } \\
\text { defendam hipóteses } \\
\text { baseando-se em } \\
\text { informações do } \\
\text { problema }\end{array}$ \\
\hline $\begin{array}{l}\text { 84. Estudante: } \\
140 .\end{array}$ & $\begin{array}{l}\text { estudantes } \\
\text { justificam } \\
\text { hipóteses }\end{array}$ & & $\begin{array}{c}\text { estudantes } \\
\text { apresenta } \\
\text { contribuições }\end{array}$ & & $\begin{array}{l}\text { estudantes } \\
\text { justificam } \\
\text { hipóteses } \\
\text { utilizando } \\
\text { pensamento } \\
\text { matemático } \\
\end{array}$ & $\begin{array}{l}\text { estudantes } \\
\text { apresentam } \\
\text { justificativas } \\
\text { coerentes }\end{array}$ & $\begin{array}{c}\text { estudantes } \\
\text { defendem hipóteses } \\
\text { baseando-se em } \\
\text { informações do } \\
\text { problema }\end{array}$ \\
\hline $\begin{array}{l}\text { 85. Professora: } \\
\text { E aí se der } \\
140 \ldots \text { Fábio:..: } \\
\text { o barco } \\
\text { afunda... por } \\
\text { quê? }\end{array}$ & $\begin{array}{l}\text { professora } \\
\text { apresenta } \\
\text { hipóteses }\end{array}$ & & $\begin{array}{c}\text { professora } \\
\text { solicita } \\
\text { contribuições }\end{array}$ & $\begin{array}{c}\text { professora faz } \\
\text { perguntas para } \\
\text { testar } \\
\text { hipóteses }\end{array}$ & $\begin{array}{c}\text { professora } \\
\text { solicita que } \\
\text { estudantes } \\
\text { justifiquem } \\
\text { hipóteses } \\
\text { utilizando } \\
\text { pensamento } \\
\text { matemático }\end{array}$ & $\begin{array}{c}\text { professora } \\
\text { solicita que } \\
\text { estudantes } \\
\text { justifiquem } \\
\text { hipóteses }\end{array}$ & $\begin{array}{c}\text { professora solicita } \\
\text { que estudantes } \\
\text { defendam hipóteses } \\
\text { baseando-se em } \\
\text { informações do } \\
\text { problema }\end{array}$ \\
\hline $\begin{array}{l}\text { 86. Estudante: } \\
\text { Por que não } \\
\text { pode passar de } \\
130 \ldots\end{array}$ & & $\begin{array}{c}\text { estudantes } \\
\text { retomam } \\
\text { critérios já } \\
\text { estabelecidos } \\
\text { para análise de } \\
\text { hipóteses }\end{array}$ & $\begin{array}{c}\text { estudante } \\
\text { apresentam } \\
\text { contribuições }\end{array}$ & & $\begin{array}{l}\text { estudantes } \\
\text { justificam } \\
\text { hipóteses } \\
\text { utilizando } \\
\text { pensamento } \\
\text { matemático }\end{array}$ & $\begin{array}{c}\text { estudantes } \\
\text { apresentam } \\
\text { justificativas } \\
\text { coerentes }\end{array}$ & $\begin{array}{c}\text { estudantes } \\
\text { defendem hipóteses } \\
\text { baseando-se em } \\
\text { informações do } \\
\text { problema }\end{array}$ \\
\hline
\end{tabular}

Quadro 14 - Episódio 6- Atividade 1- A travessia do rio - 17/09/2012 
Nesse episódio, conduzidos pela professora, os estudantes tentam encontrar a combinação adequada de pesos após assumirem o revezamento entre os três amigos como o caminho para solução do problema. Para tanto, os critérios e conhecimentos que norteiam a apresentação e avaliação das hipóteses (padrões públicos de análise) são esclarecidos por um estudante no turno 86, o que vimos acontecer, também, no turno 36 quando a professora retomou os dados do problema. Entretanto, interpretamos essas duas operações, de formas distintas.

Logo no primeiro momento de nossa análise, o problema é apresentando e compreendemos que, naquele momento, os critérios para apresentação e análise das ideias são postos para a turma, contudo, ao longo do segundo momento, conforme as primeiras hipóteses são apresentadas, percebemos que esses ainda não eram, plenamente, aceitos pelo grupo. Em consequência da não compreensão ou acolhimento desses padrões, a professora precisou apresentar outros critérios que foram, aos poucos, sendo incorporados nas hipóteses até que, no turno 36, ela sintetiza que "o barco só comporta 130 quilos... e aí um tem 60 o outro tem 65 e outro tem 80 quilos”. Pelas hipóteses que passam a ser apresentadas a partir de então, parece-nos que, neste terceiro momento, os estudantes compreendem e aceitam que esse será o padrão para apresentação e crítica de hipóteses. Ainda nessa compreensão, parece-nos que quando um estudante esclarece um critério no turno 86 não está apenas apresentando critérios, como fizera a professora, mas verbalizando algo que fora compreendido pela turma, uma vez que o argumento construído coletivamente já atende ao padrão que fora repetido e esclarecido. Ou seja, parece-nos que a norma de padrões públicos de análise orienta as práticas neste momento da aula, sendo o turno 86 , ou mesmo a linha de raciocínio construída, evidências disso.

No decorrer da análise, turnos que retomam os critérios de apresentação e avaliação de hipóteses só reaparecem no início do quarto momento quando, após cerca de 17 minutos de tentativas de construir uma explicação para o problema, os estudantes voltam a propor respostas que abandonam o pensamento matemático evidenciando que, talvez pelo cansaço ou frustração, o padrão fora abandonado, precisando ser reafirmado pela professora (turnos $167 \mathrm{e}$ 169). A ausência de turnos em que os padrões sejam repetidos não é, contudo, compreendida como ausência desses padrões, uma vez que esses seguem norteando o enfrentamento do problema, como indica o conteúdo das hipóteses.

Ao olharmos as práticas, nesse episódio, destacamos uma operação da professora que representa uma alteração na prática de fazer perguntas, tal como predominou nos momentos anteriores. Nesse episódio, podemos identificar diversos turnos $(75,77,79,83$ e 85) nos quais 
a professora faz perguntas para guiar a construção de uma explicação e para colocar hipótese em teste (turno 81), seja solicitando justificativas ou elaborações do raciocínio, o que compreendemos como relacionado ao modo como a prática de argumentação se dá a ver nessa aula. Ao ouvir as hipóteses da turma, a professora faz perguntas que articulam um argumento apresentado em fragmentos e estimula os estudantes a avaliarem e justificarem suas hipóteses a partir dos dados disponíveis, permitindo que a turma chegue mais próximo da construção de uma explicação para o problema proposto. Exemplificamos essas operações na figura abaixo, no qual representamos com dois argumentos são formados a partir das perguntas feitas.

Dois amigos fazem a primeira viagem (turno 75: Mas quem são os dois que vão?) $\rightarrow$ Esses dois amigos são os de $60 \mathrm{~kg}$ e $65 \mathrm{~kg}$ (turno 77: e vai dar quanto?) $\rightarrow$ Os dois amigos que fazem a primeira viagem são os de $60 \mathrm{~kg}$ e $65 \mathrm{~kg}$ e eles podem viajar juntos, pois seus pesos somam $125 \mathrm{~kg}$

$\mathrm{O}$ amigo de $60 \mathrm{~kg}$ e o de $80 \mathrm{~kg}$ fazem a próxima viagem (turno 81: eles podem estar no barco os dois?) $\rightarrow$ Esses dois amigos não podem viajar juntos (turno 83: Vai dá?) $\rightarrow$ Pois a soma de seus pesos é de 140kg (turno 85: o barco afunda... por quê?) $\rightarrow$ O amigo de $60 \mathrm{~kg}$ e o de $80 \mathrm{~kg}$ não podem viajar juntos, pois seus pesos somam $140 \mathrm{~kg}$ e a carga máxima da embarcação é de $130 \mathrm{~kg}$

Figura 4 - Argumentos construídos durante a resolução do problema proposto na Aula 1- A travessia do rio

Em seguida a esse episódio, os estudantes prosseguem com a apresentação de hipóteses e, em meio às ideias discutidas, parecem acreditar que um de seus colegas, Fabrício, encontrou a resposta para o problema. Confiantes nisso, quando a professora pergunta quem pensou em alguma proposta, falam que ele pode apresentar uma hipótese e, mesmo quando escutam do colega que ele não sabe a resposta, insistem em coro para que ele tente. 
Buscar novas hipóteses

\begin{tabular}{|c|c|c|c|c|c|c|}
\hline \multirow[b]{2}{*}{$\begin{array}{c}\text { Turnos } \\
\left(16{ }^{\prime} 45-17 ' 12 ’\right)\end{array}$} & \multicolumn{3}{|c|}{ Evidências de Normas Culturais } & \multicolumn{3}{|c|}{ Evidências de Práticas Culturais } \\
\hline & Fórum & $\begin{array}{l}\text { Receptividade à } \\
\text { Crítica }\end{array}$ & $\begin{array}{l}\text { Igualdade } \\
\text { Moderada }\end{array}$ & $\begin{array}{l}\text { Utilizar Pensamento } \\
\text { Matemático e } \\
\text { Ferramentas de } \\
\text { Informática } \\
\end{array}$ & $\begin{array}{l}\text { Construir } \\
\text { Explicações }\end{array}$ & $\begin{array}{l}\text { Engajar-se em } \\
\text { Argumentações } \\
\text { Baseadas em } \\
\text { Evidências }\end{array}$ \\
\hline $\begin{array}{l}\text { 119. Estudantes: FALA... } \\
\text { TENTA }\end{array}$ & & & $\begin{array}{c}\text { estudantes } \\
\text { solicitam } \\
\text { contribuições }\end{array}$ & & $\begin{array}{l}\text { estudantes solicitam } \\
\text { que outros } \\
\text { estudantes } \\
\text { apresentem hipótese }\end{array}$ & \\
\hline $\begin{array}{l}\text { 120. Professora: Fala que a } \\
\text { gente pode ter outra ideia... } \\
\text { peraí. }\end{array}$ & & & $\begin{array}{c}\text { professora } \\
\text { solicita } \\
\text { contribuições }\end{array}$ & & $\begin{array}{l}\text { professora solicita } \\
\text { que estudantes } \\
\text { apresentem } \\
\text { hipóteses }\end{array}$ & \\
\hline \multicolumn{7}{|l|}{$\begin{array}{l}\text { 121. Fabrício: Se o de } 60 \\
\text { ((outros estudantes falam } \\
\text { junto)) }\end{array}$} \\
\hline $\begin{array}{l}\text { 122. Professora: Peraí... } \\
\text { peraí... fala }\end{array}$ & & & $\begin{array}{c}\text { professora } \\
\text { solicita } \\
\text { contribuições }\end{array}$ & & $\begin{array}{l}\text { professora solicita } \\
\text { que estudantes } \\
\text { apresentem } \\
\text { hipóteses }\end{array}$ & \\
\hline $\begin{array}{l}\text { 123. Fabrício: Se o de } 60 \text { fosse } \\
\text { buscar o de } 65 . . . \text { ia dar } 125 \text { aí } \\
\text { não ia dar porque o de } 65 \text { não } \\
\text { tem como buscar o de } 80\end{array}$ & $\begin{array}{l}\text { estudantes } \\
\text { apresentam } \\
\text { hipóteses }\end{array}$ & $\begin{array}{c}\text { estudantes } \\
\text { apresentam } \\
\text { hipóteses } \\
\text { considerando críticas }\end{array}$ & $\begin{array}{c}\text { estudantes } \\
\text { apresentam } \\
\text { contribuições }\end{array}$ & $\begin{array}{c}\text { estudantes } \\
\text { apresentam hipóteses } \\
\text { utilizando } \\
\text { pensamento } \\
\text { matemático }\end{array}$ & $\begin{array}{c}\text { estudantes apresenta } \\
\text { explicações } \\
\text { coerentes }\end{array}$ & $\begin{array}{l}\text { estudante articula } \\
\text { argumentos em } \\
\text { construção }\end{array}$ \\
\hline
\end{tabular}

Quadro 15 - Episódio 7- Atividade 1- A travessia do rio - 17/09/2012 
Da perspectiva das normas culturais, este episódio segue apresentando operações já identificadas em outros momentos, como as solicitações da professora para que os estudantes falem suas hipóteses que são apresentadas e, em seguida, avaliadas pela professora. Seguimos, também, vendo as hipóteses sendo recebidas de forma respeitosas pelos estudantes, o que reforça nossa interpretação de que essa sala se configura como um fórum no qual a igualdade moderada está constituída e grande parte dos estudantes contribui para construção de uma explicação. O que destacamos neste episódio, contudo, é o que acontece no turno 119, quando os estudantes, e não a professora, solicitam que um colega apresente uma hipótese e insistem para que o faça indicando, em nossa análise, reconhecimento de sua autoridade intelectual.

Outro ponto que analisamos a partir desse episódio é a prática de construção de explicações. Conforme apresentado em nosso referencial, as comunidades científicas buscam construir explicações confiáveis sobre o mundo natural, o que é feito de forma similar nessa sala quando, coletivamente, professora e estudantes buscam construir uma resposta para o problema. Para tanto, nos turnos dos estudantes são apresentadas hipóteses, revisões e justificativas coerentes com as informações disponíveis e com o entendimento construído ao longo da aula e, intercalados a esses, temos os turnos da professora que solicita revisões e justificativas à turma, bem como destaca inconsistências nas respostas.

Esse padrão e a coerência das hipóteses apresentadas, apontam para um fortalecimento da norma de receptividade à crítica, como podemos evidenciar nos turnos $35 \mathrm{e}$ 37, quando Fabrício e Diego constroem uma explicação parcial que considera todas as críticas feitas durante o entendimento do problema. Essa resposta é retomada por Manoel (turno 74 e 76) que segue considerando a necessidade de múltiplas viagens e utilizando pensamento matemático, mesmo equivocado quanto ao cálculo ao propor que os amigos de $60 \mathrm{~kg}$ e $80 \mathrm{~kg}$ viajem juntos (turno 80).

Temos ao longo deste terceiro momento, a apresentação, crítica e defesa de hipóteses sempre baseadas nas informações do problema ou em linhas de raciocínio construídas a partir desse, o que interpretamos, não apenas, como evidências da constituição das práticas de argumentação e de uso de pensamento matemático nessa sala, mas como outro elemento para considerarmos a constituição dessa como uma comunidade de práticas, uma vez que podemos identificar a presença de engajamento mútuo, como visto pelo enfrentamento coletivo do problema; de identificação com o empreendimento, que foi negociado ao longo dos minutos iniciais da aula; e de partilha de um repertório (da matemática) que já era conhecido dos estudantes, mas foi retomado para essa situação específica. 


\subsubsection{A encenação do problema}

Apesar dos avanços na construção de uma explicação, sem conseguir resolver o problema, os estudantes começam a se dispersar e, entre conversas paralelas e queixas de que a resolução é impossível, voltam às respostas que, logo no início da aula, haviam sido assumidas como descartadas. Esse movimento de aparente desistência dá início ao nosso quarto momento cerca de quinze minutos após o aparente consenso sobre o raciocínio a ser utilizado, quando os estudantes seguem sem equacionar a solução e a professora propõe um novo caminho para resolução do problema. 
Propor um novo procedimento

\begin{tabular}{|c|c|c|c|c|c|c|c|c|}
\hline \multirow[b]{2}{*}{$\begin{array}{c}\text { Turnos } \\
\left(25,15,,-27{ }^{\prime} 26 ”\right)\end{array}$} & \multicolumn{4}{|c|}{ Evidências de Normas Culturais } & \multicolumn{4}{|c|}{ Evidências de Práticas Culturais } \\
\hline & Fórum & $\begin{array}{l}\text { Receptividade à } \\
\text { Crítica }\end{array}$ & $\begin{array}{l}\text { Padrões } \\
\text { Públicos de } \\
\text { Análise }\end{array}$ & $\begin{array}{l}\text { Igualdade } \\
\text { Moderada }\end{array}$ & $\begin{array}{c}\text { Fazer } \\
\text { Perguntas }\end{array}$ & $\begin{array}{c}\text { Planejar e } \\
\text { Executar } \\
\text { Investigações }\end{array}$ & $\begin{array}{c}\text { Utilizar } \\
\text { Pensamento } \\
\text { Matemático e } \\
\text { Ferramentas } \\
\text { de } \\
\text { Informática }\end{array}$ & $\begin{array}{c}\text { Construir } \\
\text { Explicações }\end{array}$ \\
\hline $\begin{array}{l}\text { 166. Estudantes: Dica } \\
\text { dica DICA }\end{array}$ & & & & $\begin{array}{c}\text { estudantes } \\
\text { solicitam } \\
\text { contribuições } \\
\end{array}$ & & & & \\
\hline $\begin{array}{l}\text { 167. Professora: A } \\
\text { gente já sabe que vai dar } \\
\text { certo do } 60 \text { ir junto com } \\
\text { o de } 65 . . . \text { tá bom? estou } \\
\text { dando a dica... a gente } \\
\text { já descobriu isso... e aí, } \\
\text { como é que vai fazer } \\
\text { para o de } 80 \text { também } \\
\text { chegar do outro lado? } \\
\text { [Maria: vai nadando] } \\
\text { Carolina... você chegou } \\
\text { perto... o que foi que } \\
\text { você falou aquela hora? } \\
\text { [Maria: vai nadando] } \\
\text { daquela vez }\end{array}$ & $\begin{array}{l}\text { estudantes } \\
\text { apresentam } \\
\text { hipóteses }\end{array}$ & & $\begin{array}{c}\text { professora } \\
\text { retoma } \\
\text { critérios já } \\
\text { estabelecidos } \\
\text { para análise de } \\
\text { hipóteses }\end{array}$ & $\begin{array}{c}\text { professora } \\
\text { solicita } \\
\text { contribuições } \\
\text { estudante } \\
\text { apresentam } \\
\text { contribuições } \\
\text { professora } \\
\text { ignora } \\
\text { contribuições o }\end{array}$ & $\begin{array}{l}\text { professora } \\
\text { faz } \\
\text { perguntas } \\
\text { para } \\
\text { retomar o } \\
\text { que já é } \\
\text { conhecido }\end{array}$ & & $\begin{array}{l}\text { professora } \\
\text { indica que } \\
\text { problema } \\
\text { deve ser } \\
\text { respondido } \\
\text { utilizando } \\
\text { pensamento } \\
\text { matemático }\end{array}$ & $\begin{array}{c}\text { professora } \\
\text { solicita que } \\
\text { estudantes } \\
\text { apresentem } \\
\text { hipóteses }\end{array}$ \\
\hline $\begin{array}{l}\text { 168. Carolina: O de } 60 \\
\text { vai com o de } 65 . . . \text { e vai } \\
\text { o de } 80 \text { (inaudível) }\end{array}$ & $\begin{array}{l}\text { estudantes } \\
\text { apresentam } \\
\text { hipóteses }\end{array}$ & $\begin{array}{c}\text { estudantes } \\
\text { apresentam } \\
\text { hipóteses } \\
\text { desconsiderando } \\
\text { críticas }\end{array}$ & & $\begin{array}{c}\text { estudantes } \\
\text { apresentam } \\
\text { contribuições }\end{array}$ & & & $\begin{array}{l}\text { estudantes } \\
\text { apresentam } \\
\text { hipóteses } \\
\text { utilizando } \\
\text { pensamento } \\
\text { matemático }\end{array}$ & $\begin{array}{l}\text { estudantes } \\
\text { apresentam } \\
\text { hipóteses } \\
\text { incoerentes }\end{array}$ \\
\hline 169. Professora: Vai os & professora & & professora & & & & professora & professora \\
\hline
\end{tabular}




\begin{tabular}{|c|c|c|c|c|c|c|c|}
\hline $\begin{array}{l}\text { três? não dá... afunda o } \\
\text { barco. }\end{array}$ & $\begin{array}{c}\text { critica } \\
\text { hipóteses }\end{array}$ & & \begin{tabular}{|c|} 
retoma \\
critérios já \\
estabelecidos \\
para análise de \\
hipóteses \\
\end{tabular} & & & $\begin{array}{c}\text { critica } \\
\text { hipóteses } \\
\text { utilizando } \\
\text { pensamento } \\
\text { matemático }\end{array}$ & $\begin{array}{c}\text { indica } \\
\text { inconsistências } \\
\text { em hipóteses }\end{array}$ \\
\hline
\end{tabular}

Quadro 16 - Episódio 8- Atividade 1- A travessia do rio - 17/09/2012 
Sem encontrar uma resposta para o problema, os estudantes dispersam a atenção para outros assuntos e apelam para comentários que buscam levar a professora a lhes oferecer a resolução esperada, solicitando em coro, no turno 166, uma dica. Categorizamos essa operação como relativa à norma de igualdade moderada, pois parece-nos que, frustrados por não encontrar a solução, os estudantes recorrem à professora, reconhecida como membro com maior conhecimento naquela comunidade, a fim de que uma contribuição dê novos rumos para resolução do problema.

Atendendo à solicitação da turma, a professora, em um primeiro instante, retoma a resposta parcial que já fora legitimada e, então, questiona Carolina sobre algo que já fora apresentado a fim de uma hipótese correta. Consideramos que, com essa operação, a professora se aproxima da prática das comunidades científicas de fazer perguntas a fim de identificar o que já é conhecido na área. Em resposta, Carolina apresenta uma hipótese que desconsidera críticas feitas ao longo da aula ao propor que os três amigos viajem juntos o que, já é sabido, afundaria o barco.

Nessa sequência, podemos dizer que um fórum continua estabelecido e as hipóteses seguem sendo comunicadas e avaliadas, como ocorrera nos momentos anteriores, contudo, a receptividade à crítica e os padrões públicos de análise parecem se esvair ao ponto de Maria propor no turno 170 "Vai um segurando... nadando assim", o que já não era considerado pela turma desde o início dessa aula. Essa hipótese que, no turno 12 já havia sido discutida e criticada pela professora é, aparentemente, ignorada duas vezes pela professora no turno 167, evidenciando, possivelmente, um enfraquecimento, também, da igualdade moderada.

Nessa nova configuração de normas, as ideias apresentadas são incoerentes e não baseadas em informações do problema, mudando, também, o que vinha caracterizando as práticas de construção de explicações e de uso do pensamento matemático que se estabeleceram durante a resolução do problema. Frente a essa nova situação, sem ver resultados positivos, a professora propõe um procedimento para testar e desenvolver hipóteses, implicando em uma última transformação no planejamento e execução que fora proposto na SEI. 
Criar sobre o sugerido

\begin{tabular}{|c|c|c|c|c|c|c|c|c|c|}
\hline \multirow[b]{2}{*}{$\begin{array}{l}\text { Turnos } \\
\left(27 ' 53^{\prime \prime},-\right. \\
\left.295^{\prime \prime}\right)\end{array}$} & \multicolumn{4}{|c|}{ Evidências de Normas Culturais } & \multicolumn{5}{|c|}{ Evidências de Práticas Culturais } \\
\hline & Fórum & $\begin{array}{l}\text { Receptividade } \\
\text { à Crítica }\end{array}$ & $\begin{array}{c}\text { Padrões } \\
\text { Públicos de } \\
\text { Análise }\end{array}$ & $\begin{array}{l}\text { Igualdade } \\
\text { Moderada }\end{array}$ & $\begin{array}{c}\text { Fazer } \\
\text { Perguntas }\end{array}$ & $\begin{array}{c}\text { Planejar e } \\
\text { Executar } \\
\text { Investigações }\end{array}$ & $\begin{array}{c}\text { Utilizar } \\
\text { Pensamento } \\
\text { Matemático e } \\
\text { Ferramentas } \\
\text { de } \\
\text { Informática } \\
\end{array}$ & $\begin{array}{c}\text { Construir } \\
\text { Explicações }\end{array}$ & $\begin{array}{c}\text { Engajar-se em } \\
\text { Argumentações } \\
\text { Baseadas em } \\
\text { Evidências }\end{array}$ \\
\hline $\begin{array}{l}176 . \\
\text { Professora: } \\
\text { Peraí... } \\
\text { peraí... quem } \\
\text { é que vai } \\
\text { primeiro no } \\
\text { barco? }\end{array}$ & & & & $\begin{array}{c}\text { professora } \\
\text { solicita } \\
\text { contribuições }\end{array}$ & $\begin{array}{l}\text { professora faz } \\
\text { perguntas } \\
\text { para guiar a } \\
\text { construção de } \\
\text { explicações }\end{array}$ & \multirow{3}{*}{$\begin{array}{c}\text { professora e } \\
\text { estudantes } \\
\text { conduzem e } \\
\text { observam } \\
\text { procedimentos } \\
\text { para testar e } \\
\text { desenvolver } \\
\text { hipóteses }\end{array}$} & $\begin{array}{l}\text { professora } \\
\text { solicita que } \\
\text { estudantes } \\
\text { apresentem } \\
\text { hipóteses } \\
\text { utilizando } \\
\text { pensamento } \\
\text { matemático }\end{array}$ & $\begin{array}{l}\text { professora } \\
\text { solicita que } \\
\text { estudantes } \\
\text { apresentem } \\
\text { hipóteses }\end{array}$ & \\
\hline $\begin{array}{l}177 . \\
\text { Estudante: } \\
\text { Vai o de } 60 \\
\text { [Natan: eu] }\end{array}$ & $\begin{array}{l}\text { estudantes } \\
\text { apresentam } \\
\text { hipóteses }\end{array}$ & $\begin{array}{c}\text { estudantes } \\
\text { apresentam } \\
\text { hipóteses } \\
\text { considerando } \\
\text { críticas }\end{array}$ & & $\begin{array}{c}\text { estudantes } \\
\text { apresentam } \\
\text { contribuições }\end{array}$ & & & $\begin{array}{l}\text { estudantes } \\
\text { apresentam } \\
\text { hipóteses } \\
\text { utilizando } \\
\text { pensamento } \\
\text { matemático }\end{array}$ & $\begin{array}{l}\text { estudantes } \\
\text { apresentam } \\
\text { hipóteses } \\
\text { coerentes }\end{array}$ & \\
\hline $\begin{array}{l}178 . \\
\text { Professora: } \\
\text { Vamos pôr o } \\
\text { de } 60 \text { no } \\
\text { barco ((a } \\
\text { professora } \\
\text { puxa o } \\
\text { estudante } \\
\text { para perto de } \\
\text { si no centro } \\
\text { da sala)) o de } \\
60 \text { já está no } \\
\text { barco... e }\end{array}$ & $\begin{array}{l}\text { professora } \\
\text { repete } \\
\text { hipóteses }\end{array}$ & & & $\begin{array}{c}\text { professora } \\
\text { solicita } \\
\text { contribuições }\end{array}$ & $\begin{array}{l}\text { professora faz } \\
\text { perguntas } \\
\text { para guiar a } \\
\text { construção de } \\
\text { explicações }\end{array}$ & & $\begin{array}{l}\text { professora } \\
\text { solicita que } \\
\text { estudantes } \\
\text { apresentem } \\
\text { hipóteses } \\
\text { utilizando } \\
\text { pensamento } \\
\text { matemático }\end{array}$ & $\begin{array}{l}\text { professora } \\
\text { solicita que } \\
\text { estudantes } \\
\text { apresentem } \\
\text { hipóteses }\end{array}$ & \\
\hline
\end{tabular}




\begin{tabular}{|c|c|c|c|c|c|c|}
\hline \multicolumn{7}{|l|}{ agora? } \\
\hline $\begin{array}{l}179 . \\
\text { Estudantes: } \\
65\end{array}$ & $\begin{array}{l}\text { estudantes } \\
\text { apresentam } \\
\text { hipóteses }\end{array}$ & $\begin{array}{l}\text { estudantes } \\
\text { apresentam } \\
\text { hipóteses } \\
\text { considerando } \\
\text { críticas }\end{array}$ & $\begin{array}{l}\text { estudantes } \\
\text { apresentam } \\
\text { contribuições }\end{array}$ & $\begin{array}{c}\text { estudantes } \\
\text { apresentam } \\
\text { hipóteses } \\
\text { utilizando } \\
\text { pensamento } \\
\text { matemático }\end{array}$ & $\begin{array}{c}\text { estudantes } \\
\text { apresentam } \\
\text { hipóteses } \\
\text { coerentes }\end{array}$ & \\
\hline $\begin{array}{l}180 . \\
\text { Professora: } \\
\text { Põe o de } 65 \\
\text { ((traz o } \\
\text { segundo } \\
\text { estudante } \\
\text { para o } \\
\text { centro)) } \\
\text { beleza }\end{array}$ & $\begin{array}{l}\text { professora } \\
\text { repete } \\
\text { hipóteses }\end{array}$ & & & & & \\
\hline $\begin{array}{l}\text { 181. Maria: } \\
\text { Agora leva } \\
\text { pra lá } \\
\text { ((apontando } \\
\text { para o outro } \\
\text { lado. As } \\
\text { crianças que } \\
\text { representam } \\
\text { os homens de } \\
60 \text { e } 65 \text { quilos } \\
\text { vão para o } \\
\text { outro lado da } \\
\text { sala)) }\end{array}$ & $\begin{array}{l}\text { estudantes } \\
\text { apresentam } \\
\text { hipóteses }\end{array}$ & $\begin{array}{l}\text { estudantes } \\
\text { apresentam } \\
\text { hipóteses } \\
\text { considerando } \\
\text { críticas }\end{array}$ & $\begin{array}{c}\text { estudantes } \\
\text { apresentam } \\
\text { contribuições }\end{array}$ & $\begin{array}{c}\text { estudantes } \\
\text { apresentam } \\
\text { hipóteses } \\
\text { utilizando } \\
\text { pensamento } \\
\text { matemático }\end{array}$ & $\begin{array}{c}\text { estudantes } \\
\text { apresentam } \\
\text { hipóteses } \\
\text { coerentes }\end{array}$ & \\
\hline $\begin{array}{l}182 . \\
\text { Professora: } \\
\text { Vai... o barco } \\
\text { leva os dois } \\
\text { para o outro } \\
\text { lado do rio... }\end{array}$ & $\begin{array}{l}\text { professora } \\
\text { repete } \\
\text { hipóteses }\end{array}$ & & & & & \\
\hline
\end{tabular}




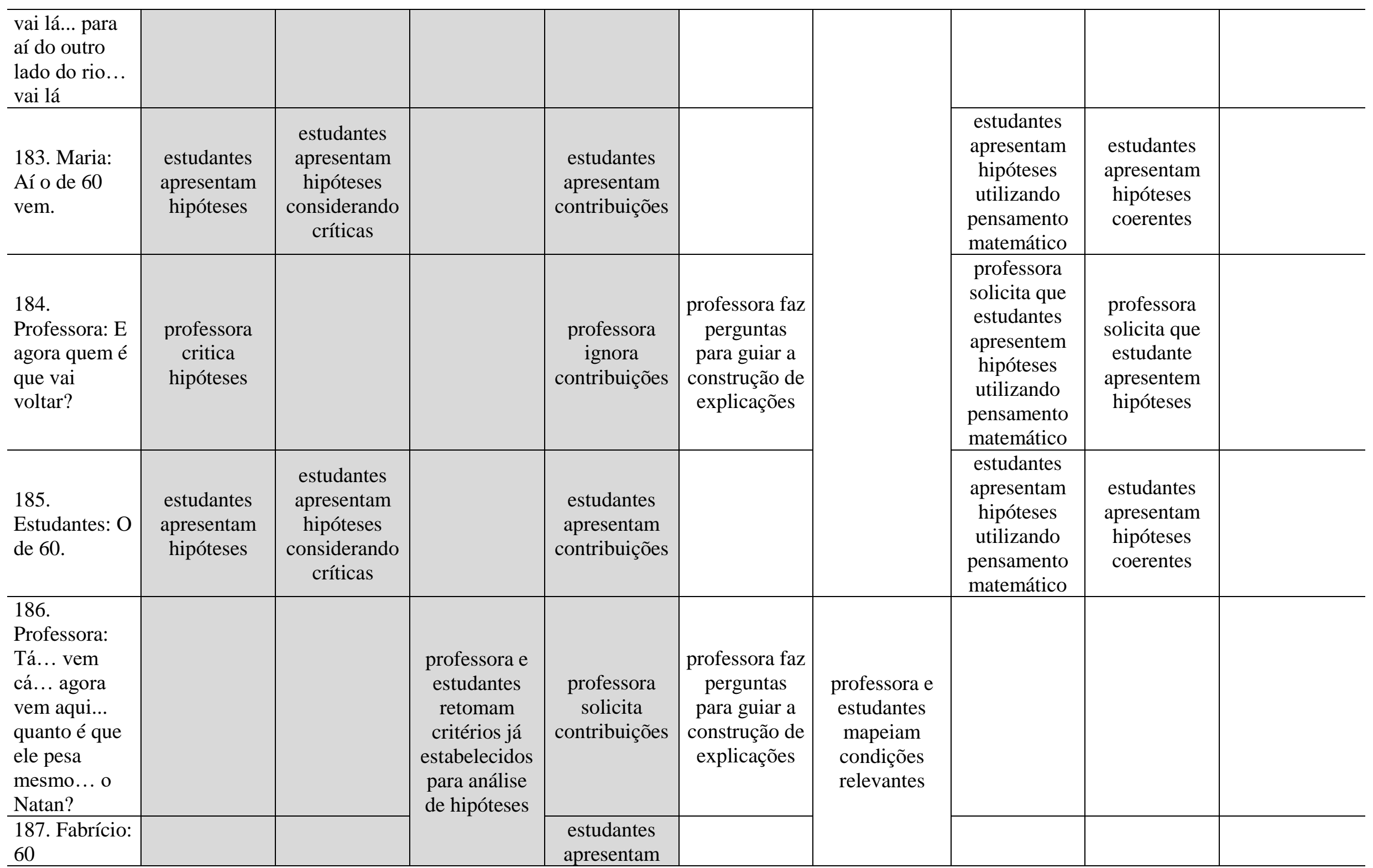




\begin{tabular}{|c|c|c|c|c|c|c|c|}
\hline & & & contribuições & & & & \\
\hline $\begin{array}{l}189 . \\
\text { Estudantes: } \\
80\end{array}$ & & & $\begin{array}{c}\text { estudantes } \\
\text { apresentam } \\
\text { contribuições }\end{array}$ & & & & \\
\hline $\begin{array}{l}191 . \\
\text { Estudantes: } \\
\text { Não }\end{array}$ & $\begin{array}{l}\text { estudantes } \\
\text { apresentam } \\
\text { hipóteses }\end{array}$ & $\begin{array}{c}\text { estudantes } \\
\text { apresentam } \\
\text { hipóteses } \\
\text { considerando } \\
\text { críticas } \\
\end{array}$ & $\begin{array}{c}\text { estudantes } \\
\text { apresentam } \\
\text { contribuições }\end{array}$ & & & $\begin{array}{l}\text { estudantes } \\
\text { apresentam } \\
\text { avaliações } \\
\text { coerentes }\end{array}$ & \\
\hline $\begin{array}{l}192 . \\
\text { Professora: } \\
\text { Vai dá? }\end{array}$ & $\begin{array}{l}\text { professora } \\
\text { critica } \\
\text { hipóteses }\end{array}$ & & $\begin{array}{c}\text { professora } \\
\text { solicita } \\
\text { contribuições }\end{array}$ & $\begin{array}{c}\text { professora faz } \\
\text { perguntas } \\
\text { para guiar a } \\
\text { construção de } \\
\text { explicações }\end{array}$ & $\begin{array}{c}\text { professora } \\
\text { solicita que } \\
\text { estudantes } \\
\text { justifiquem } \\
\text { hipóteses } \\
\text { utilizando } \\
\text { pensamento } \\
\text { matemático }\end{array}$ & $\begin{array}{l}\text { professora } \\
\text { solicita que } \\
\text { estudantes } \\
\text { justifiquem } \\
\text { hipóteses }\end{array}$ & $\begin{array}{c}\text { professora } \\
\text { solicita que } \\
\text { estudantes } \\
\text { defendam } \\
\text { hipóteses } \\
\text { baseando-se } \\
\text { em } \\
\text { informações do } \\
\text { problema }\end{array}$ \\
\hline $\begin{array}{l}193 . \\
\text { Estudantes: } \\
140\end{array}$ & $\begin{array}{l}\text { estudantes } \\
\text { justificam } \\
\text { hipóteses }\end{array}$ & & $\begin{array}{c}\text { estudantes } \\
\text { apresentam } \\
\text { contribuições }\end{array}$ & & $\begin{array}{c}\text { estudantes } \\
\text { justificam } \\
\text { hipóteses } \\
\text { utilizando }\end{array}$ & $\begin{array}{c}\text { estudantes } \\
\text { apresentam } \\
\text { justificativas } \\
\text { coerentes } \\
\end{array}$ & $\begin{array}{c}\text { estudantes } \\
\text { defendem } \\
\text { hipóteses } \\
\text { baseando-se }\end{array}$ \\
\hline
\end{tabular}




\begin{tabular}{|c|c|c|c|c|c|c|}
\hline & & & & $\begin{array}{l}\text { pensamento } \\
\text { matemático }\end{array}$ & & $\begin{array}{c}\text { em } \\
\text { informações do } \\
\text { problema }\end{array}$ \\
\hline $\begin{array}{l}194 . \\
\text { Professora: } \\
140 \text { vai } \\
\text { acontecer o } \\
\text { quê? } \\
\text { [estudantes: } \\
\text { vai afundar] } \\
\text { vai afundar... } \\
\text { então... }\end{array}$ & $\begin{array}{l}\text { professora e } \\
\text { estudantes } \\
\text { retomam } \\
\text { critérios já } \\
\text { estabelecidos } \\
\text { para análise } \\
\text { de hipóteses }\end{array}$ & $\begin{array}{l}\text { professora } \\
\text { solicita } \\
\text { contribuições }\end{array}$ & $\begin{array}{c}\text { professora faz } \\
\text { perguntas } \\
\text { para guiar a } \\
\text { construção de } \\
\text { explicações }\end{array}$ & $\begin{array}{c}\text { professora } \\
\text { solicita que } \\
\text { estudantes } \\
\text { justifiquem } \\
\text { hipóteses } \\
\text { utilizando } \\
\text { pensamento } \\
\text { matemático } \\
\text { estudantes } \\
\text { justificam } \\
\text { hipóteses } \\
\text { utilizando } \\
\text { pensamento } \\
\text { matemático }\end{array}$ & $\begin{array}{c}\text { professora } \\
\text { solicita que } \\
\text { estudantes } \\
\text { justifiquem } \\
\text { hipóteses } \\
\text { estudantes } \\
\text { apresentam } \\
\text { justificativas } \\
\text { coerentes }\end{array}$ & $\begin{array}{c}\text { professora } \\
\text { solicita que } \\
\text { estudantes } \\
\text { defendam } \\
\text { hipóteses } \\
\text { baseando-se } \\
\text { em } \\
\text { informações do } \\
\text { problema } \\
\text { estudantes } \\
\text { defendem } \\
\text { hipóteses } \\
\text { baseando-se } \\
\text { em } \\
\text { informações do } \\
\text { problema }\end{array}$ \\
\hline $\begin{array}{l}196 . \\
\text { Professora: } \\
\text { Olha que } \\
\text { legal aquilo } \\
\text { que ele } \\
\text { pensou o... } \\
\text { olha o que } \\
\text { que o } \\
\text { Adriano } \\
\text { falou... } \\
\text { repete bem } \\
\text { alto para ver }\end{array}$ & & $\begin{array}{l}\text { professora } \\
\text { solicita } \\
\text { contribuições }\end{array}$ & & & $\begin{array}{l}\text { professora } \\
\text { solicita que } \\
\text { estudantes } \\
\text { apresentem } \\
\text { hipóteses }\end{array}$ & \\
\hline
\end{tabular}




\begin{tabular}{|c|c|c|c|c|c|c|}
\hline \multicolumn{7}{|l|}{$\begin{array}{l}\text { se está certo } \\
\text { isso }\end{array}$} \\
\hline $\begin{array}{l}\text { 197. Adriano: } \\
\text { O de } 80 \text { vai... } \\
\text { aí o de } 65 \\
\text { volta para } \\
\text { pegar o de } 60\end{array}$ & $\begin{array}{l}\text { estudantes } \\
\text { apresentam } \\
\text { hipóteses }\end{array}$ & $\begin{array}{l}\text { estudantes } \\
\text { apresentam } \\
\text { hipóteses } \\
\text { considerando } \\
\text { críticas }\end{array}$ & $\begin{array}{c}\text { estudantes } \\
\text { apresentam } \\
\text { contribuições }\end{array}$ & & $\begin{array}{l}\text { estudantes } \\
\text { apresentam } \\
\text { hipóteses } \\
\text { utilizando } \\
\text { pensamento } \\
\text { matemático }\end{array}$ & $\begin{array}{l}\text { estudantes } \\
\text { apresentam } \\
\text { hipóteses } \\
\text { coerentes }\end{array}$ \\
\hline $\begin{array}{l}198 . \\
\text { Professora: } \\
\text { Vamos tentar } \\
\text { para ver se dá } \\
\text { certo? }\end{array}$ & & & $\begin{array}{c}\text { professora } \\
\text { solicita } \\
\text { contribuições }\end{array}$ & $\begin{array}{c}\text { professora faz } \\
\text { perguntas } \\
\text { para testar } \\
\text { hipóteses }\end{array}$ & $\begin{array}{c}\text { professora } \\
\text { solicita que } \\
\text { estudantes } \\
\text { avaliem } \\
\text { hipóteses } \\
\text { utilizando } \\
\text { pensamento } \\
\text { matemático }\end{array}$ & $\begin{array}{c}\text { professora } \\
\text { solicita que } \\
\text { estudantes } \\
\text { avaliem } \\
\text { hipóteses }\end{array}$ \\
\hline
\end{tabular}

Quadro 17 - Episódio 9- Atividade 1- A travessia do rio - 17/09/2012 
Sob a ótica das normas, nesse episódio podemos perceber o restabelecimento dos padrões públicos de análise, da receptividade à crítica e da igualdade moderada que entendemos como enfraquecidas no episódio anterior. Com relação aos padrões públicos de análise, por exemplo, ao considerarmos o conteúdo da explicação em construção, compreendemos que critérios já estabelecido - como "só que a distância é muito grande e não dá para empurrar o barco de volta...” (professora, turno 10); “ [...] só AS TRÊS pessoas... a três estão desse lado aqui do rio... as TRÊS estão ali e tem que chegar do OUTRO lado do rio..." (professora, turno 16); "como é que você vai trazer o barco de volta?" (Natan, turno 23); e "aí não ia dar porque o de 65 não tem como buscar o de 80" (Fabrício, turno 123) voltam a orientar a apresentação e análise de hipóteses sobre ao primeira (turnos 176 a 182) e segunda travessia (turnos 183 a 185) a serem realizadas pelos amigos e interpretadas por Natan e Hugo.

Encenado o início do problema, antes de solicitar aos estudantes que proponham como seria a travessia envolvendo o amigo de $80 \mathrm{~kg}$ e que, até então, não fora compreendida pela turma, a professora relembra algumas condições relevantes para planejamento $e$ execução da investigação, como o peso dos amigos (turnos 186 a 189) e o fato de o amigo de $80 \mathrm{~kg}$ não poder entra na embarcação com os demais (turno 190 a 194). Com isso, a sala relembra alguns dos padrões que já foram estabelecidos anteriormente como critérios que organizam e dão suporte à análise de novas ideias.

Para pensarmos a reconstituição da igualdade moderada, trazemos algumas sequências de turnos nos quais o padrão de solicitação e apresentação de contribuições se restabelece, como os intervalos que vão do turno 176 ao 179 e do turno 184 ao 194. Como outro exemplo de que os estudantes são considerados e se consideram capazes de contribuir, podemos falar do turno 181 nos qual Maria se antecipa à professora na condução da representação, tendo sua intervenção acolhida, ou do turno 195, quando Adriano, de forma espontânea, apresenta a última etapa necessária para resolução do problema.

Ainda sobre a igualdade moderada, vemos Maria, mais uma vez, ser ignorada pela professora (turno 183) o que, todavia, analisamos de forma distinta do que ocorrera no turno 170, quando a estudante, provavelmente, foi ignorada por apresentar uma hipótese incoerente. Nessa passagem, parece-nos que a fala da aluna é desconsiderada, não por seu conteúdo, mas para que a professora pudesse dar voz aos demais e verificar se aquele entendimento era partilhado pela turma. Frente a esses dados, cremos que a igualdade de autoridade intelectual em sala se restabelece nesse episódio e que todos podem apresentar e revisar ideias. 
Já com relação à receptividade à crítica, a partir do que evidenciamos sobre os padrões públicos de análise, podemos dizer que existe, nesse episódio, um acolhimento à revisão de hipóteses a partir dos comentários que foram feitos ao longo de toda aula. Como exemplo, podemos destacar o turno 190, quando a professora coloca uma hipótese em teste e essa é descartada pela turma que já estabelecera que aqueles amigos não poderiam viajar juntos. Como outro exemplo de aceite das críticas e reflexão a partir dessas, Adriano (turno 198) sintetiza o que vinha sendo discutido pela sala e consegue superar a constante inconsistência que marcava as hipóteses sobre o deslocamento do amigo de $80 \mathrm{~kg}$, ao propor que "o de 80 vai... aí o de 65 volta para pegar o de 60 ”.

Durante esse episódio, encontramos evidências de que a livre apresentação, crítica e revisão de hipóteses está presente, configurado a sala de aula como um fórum no qual professora e estudantes puderam, juntos, construir uma resposta para o problema proposto. Acreditamos que essa resolução se deu, justamente, pela construção de um espaço no qual todos pudessem contribuir, pois, como observam Gonzalez-Howard e McNeill (2016) ao analisar comunidades de práticas estabelecidas em salas de aula, a interação constituída entre os membros possibilita o desenvolvimento de um entendimento mais complexo que supera a soma das contribuições individuais.

Passando para análise das práticas, identificamos o fazer pergunta se caracterizar, como acontecera no terceiro momento da aula, por operações que guiam a turma para construção de uma explicação justificada e baseada em um raciocínio construído a partir do pensamento matemático e das informações do problema. Assim, se não temos uma explicação completa ou um argumento baseado em evidências na fala de um único estudante, vemos esses elementos surgirem por meio das perguntas da professora que guiam a turma na apresentação de hipóteses coerentes, na defesa de suas ideias e na construção de justificativas baseadas em dados do problema. Ao fim desse processo, temos uma proposição coletiva, conforme organizamos abaixo.

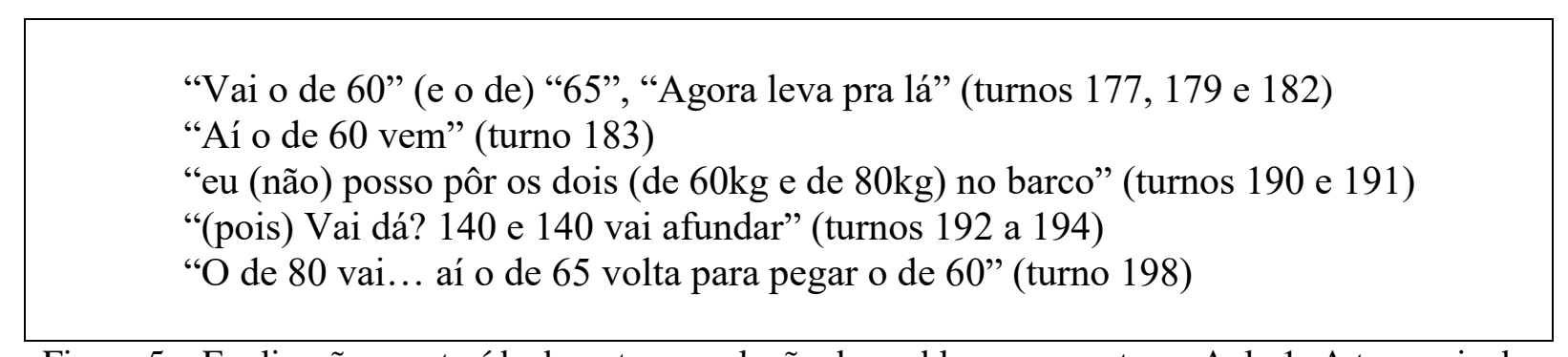

Figura 5 - Explicação construída durante a resolução do problema proposto na Aula 1- A travessia do rio 
Em outras passagens desse episódio, como também fazem membros de comunidades científicas, a professora faz perguntas para colocar uma hipótese em teste. Isso pode ser visto no turno 190, quando a professora pergunta para os estudantes se "eu posso pôr os dois no barco?" o que, contudo, já é sabido pela turma, servindo menos para testar uma hipótese e mais para guiar a construção de uma explicação coerente e retomar as condições do problema. Já no turno 198, a pergunta, de fato, convida a turma a testar uma hipótese que, até então, não havia sido considerada.

Ainda nesse episódio, podemos falar de uma nova operação na prática de planejamento e execução da investigação que é a condução e observação de um procedimento para testar e desenvolver hipóteses. Optamos por categorizar a representação do problema nessa prática, pois, como apresenta NRC (2011) a escolha de procedimentos que permitem testar teorias e explicações existentes ou revisar e desenvolver novas ideias, bem como a realização de observações são operações próprias do planejamento e execução de investigações pelas comunidades científicas. Pela condução e observação da encenação do que vinha sendo discutido, os estudantes podem vivenciar e visualizar a situação dos três amigos e, assim, explicar o que em termos, unicamente, abstratos não pôde ser concluído.

Para construir explicações, vemos a professora e os estudantes agirem coletivamente em uma sequência de apresentações, testes e justificativas de hipóteses que conduzem à solução do problema. Para tanto, todos precisam utilizar pensamento matemático, o que podemos exemplificar entre os turnos 176 e 179, quando a professora solicita que hipóteses sejam apresentadas e os estudantes as constroem utilizando pensamento matemático, ou entre os turnos 190 e 194, quando a impossibilidade de colocarmos os amigos de $60 \mathrm{~kg}$ e $80 \mathrm{~kg}$ juntos no barco é justificada por meio de um cálculo. É nesse cálculo, também, que identificamos a prática de argumentação baseada em informações do problema, na medida em que os estudantes são convidados a defender uma hipótese e o fazem a partir das informações disponibilizadas no problema.

Como tentamos mostrar na análise desse episódio, em sua criação sobre a SEI, a professora consegue proceder com o que Certeau (1985) chama de golpe. Ao propor outra maneira de encontrar a resolução do problema, não abandona o planejamento da aula, mas aproveita a ocasião, as possibilidades que a circunstância lhe oferece e improvisa sobre ele. Ao vivenciarem de forma concreta a situação, os estudantes vão testando suas hipóteses e, conjuntamente, encontram a solução dentro da lógica matemática. Nesse percurso, a todo tempo a professora relembra as condições do problema e pede aos estudantes justifiquem suas hipóteses. 
5.1.5 Considerações sobre a atividade "A travessia do rio"

Ao longo da análise, pudemos destacar algum operações culturais, a atividade produtiva realizada, coletivamente, pela professora e pelos estudantes na aula em análise e por meio das quais buscamos, compreender as normas e práticas culturais do Ensino de Ciências por Investigação, isto é, as maneiras de fazer produzidas e partilhadas por esse grupo a partir dos bens e mensagens disponibilizados durante a realização das atividades, bem como as normas que organizam e dão suporte a essas maneiras de fazer.

\section{NORMAS CULTURAIS DO ENSINO DE CIÊNCIAS POR INVESTIGACÃO}

\section{Fórum}

- Estudantes apresentam/ criticam/ revisam/ justificam hipóteses

- Professora apresenta/critica/repete hipóteses/planos de trabalho/ métodos de investigação

\section{Receptividade à crítica}

- Estudantes apresentam hipóteses desconsiderando críticas

- Estudantes apresentam/ revisam hipóteses considerando críticas

\section{Padrões públicos de análise}

- Estudantes retomam critérios já estabelecidos para análise de hipóteses

- Professora apresenta critérios para análise de hipótesess

- Professora retoma critérios já estabelecidos para análise de hipóteses

\section{Igualdade Moderada}

- Estudantes apresentam/ solicitam contribuições

- Estudantes solicitam autorização para falar

- Professora solicita/ interrompe/ ignora contribuições

$$
\text { PRÁTICAS CULTURAIS DO ENSINO DE CIÊNCIAS POR INVESTIGAÇÃO }
$$

\section{Fazer perguntas}

- Estudantes fazem perguntas para testar hipóteses

- Professora apresenta problema

- Professora faz perguntas para guiar a construção de explicações

- Professora faz perguntas para retomar o que já é conhecido

- Professora faz perguntas para testar hipóteses

\section{Desenvolver e utilizar modelos}

$--$ 
- Estudantes mapeiam condições relevantes

- Professora e estudantes conduzem e observam procedimentos para testar e desenvolver hipóteses

- Professora mapeia condições relevantes

- Professora propõe procedimentos para testar e desenvolver hipóteses

\section{Analisar e interpretar dados}

- Professora cria ferramentas para organizar dados

\section{Utilizar pensamento matemático e ferramentas computacionais}

- Estudantes apresentam/ revisam/ justificam hipóteses utilizando pensamento matemático

- Professora solicita que estudantes apresentem/ revisem/ justifiquem/ testem hipóteses utilizando pensamento matemático

- Professora indica que problema deve ser respondido utilizando pensamento matemático

- Professora critica hipóteses utilizando pensamento matemático

\section{Construir explicações}

- Estudantes solicitam que outros estudantes apresentem hipóteses

- Estudantes apresentam hipóteses/ justificativas/ avaliações coerentes

- Estudantes apresentam hipóteses incoerentes

- Estudantes indicam inconsistências em hipóteses

- Professora solicita que estudantes apresentem/ revisem/ justifiquem/ avaliem hipóteses

- Professora indica inconsistências em hipóteses

\section{Engajar-se em argumentações baseadas em evidências}

- Estudantes avançam com/ defendem/ criticam hipóteses baseando-se em informações do problema

- Estudantes articulam argumentos em construção

- Professora solicita que estudantes avancem com/ defendam hipóteses baseando-se em informações do problema

\section{Obter, avaliar e comunicar informações}

$--$

Quadro 18 - Síntese das normas e práticas presentes na Aula 1- A travessia do rio

Nessa aula, encontramos evidências do que convencionamos para este trabalho como as quatro normas para construção de explicações científicas para os problemas propostos e de SEI das oito práticas das comunidades científicas nas quais os estudantes de ciências devem ser iniciados, sendo que uma dessas, analisar e interpretar dados, apareceu de forma pontual em um único momento da aula. Acreditamos, entretanto, que as lacunas nas práticas não seja um obstáculo para o trabalho com as mesmas, uma vez que estamos lidando com uma sequência composta por onze atividades que, em seus objetivos, procedimentos e exercícios específicos, poderão dar conta das demais práticas. 
Uma vez que nesta seção analisamos uma atividade centrada em um problema matemático, iniciamos pela prática de utilizar pensamento matemático e ferramentas computacionais, mas que aqui resume-se ao uso do pensamento matemático, como podemos ver em operações da professora que oferece indícios para os estudantes de que o problema deve ser respondido utilizando pensamento matemático e serve-se desse repertório para criticar as hipóteses que são apresentadas. Esse repertório está presente, também, no uso do cálculo solicitado pela professora e empregado pelos estudantes para apresentação, revisão, teste e justificativa de hipóteses. É, ainda, pelo uso do pensamento matemático que os estudantes avançam com suas hipóteses e as defendem, conforme estimulado pela professora e, assim, engajam-se em argumentações não baseadas em evidências, mas no repertório da matemática e nas informações presentes no texto, conforme planejado na SEI.

Segundo o NRC (2011), é importante que, nas aulas de ciências, os estudantes possam perceber o processo de argumentação necessário para avançar e defender uma nova ideia ou explicação, bem como identificar e vivenciar as normas para a participação no processo argumentativo. A partir de nossa análise, acreditamos que, ainda que essas normas não sejam explicitadas pela professora e, ainda que os argumentos tenham sido construídos coletivamente, a prática está presente em alguns momentos da aula permitindo, mesmo de forma incipiente, que a turma compreenda e vivencie o processo de argumentação necessário para construção da explicação para o problema.

Outra prática bastante recorrente nessa aula é a de construir explicações, manifestando-se por uma gama de operações que vão da solicitação e apresentação de hipóteses, justificativas e avaliações, passando pela apresentação de explicações incoerentes e pela indicação de inconsistências, para, por fim, levar à construção de uma explicação que articule as condições do problema e as discussões realizadas ao longo da aula. Uma vez que nessa atividade não se objetivou ensinar um conceito ou fato para a turma, não podemos dizer que a prática se caracterizou por apresentar explicações desenvolvidas e já legitimadas para os estudantes, todavia, parece-nos que a professora logrou sucesso em convidar os estudantes a construir explicações ao problema proposto, encorajando-os a avaliar as explicações em construção e a compará-las com as informações disponíveis a fim de identificar suas inconsistências.

Observando a prática de planejar e executar investigações, temos algumas operações que resultam no redirecionamento dos rumos da atividade. Como primeira dessas, o mapeamento de condições relevantes realizado, coletivamente, pelos estudantes e pela professora e que resultou em um primeiro replanejamento da SEI, à medida em que o 
entendimento do problema foi negociado por toda turma, extrapolando o limite dos grupos que, como proposto, deveriam iniciar a aula trabalhando separadamente. Como outra operação, destacamos a proposição de um procedimento não estipulado na SEI que foi, então, conduzido e observado por toda sala que pode se envolver em algumas tomadas de decisões, justificando suas escolhas. Parece-nos que, ao mapear condições relevantes para a resolução do problema e solicitar desenvolvimento das ideias apresentadas, a professore sobre explorar as hipóteses dos estudantes e ajuda-los na construção de um plano de investigação nas qual as ideias eram revisadas à luz das críticas feitas

Durante o entendimento do problema, surge uma operação à prática de analisar $e$ interpretar dados que, nas comunidades científicas é caracterizada pelo uso de ferramentas que permitam identificar os recursos e padrões significativos nos dados a fim de que esses possam ser utilizados como evidência. Nesta atividade, o trabalho com grandes volumes de dados não era previsto, entretanto, vemos a lista criada pela professora uma ferramenta para organização das informações explícitas e implícitas no problema a fim de ajudar os estudantes com a construção das primeiras hipóteses. Ainda que a ferramenta não tenha sido adotada, o propósito da professora parece ter sido alcançado e vemos no segundo momento da aula a proposição de hipóteses que são, posteriormente, justificadas e avaliadas ao longo do terceiro e do quarto momento, o que sugere a presença de práticas epistêmicas nessa aula. À medida em que os estudantes justificam suas escolhas e explicitam o porquê de aquelas hipóteses poderem ser consideradas corretas, vemos algumas maneiras de propor, comunicar e avaliar explicações para o problema. Essas maneiras de fazer, nas comunidades científicas, acompanhadas da legitimação compõem as práticas epistêmicas pelas quais o conhecimento é construído (KELLY; LICONA, 2018).

Por fim, como última das práticas em análise, temos o fazer perguntas evidenciado ao longo de toda aula, principalmente em operações da professora que, após apresentar o problema, seguiu fazendo questionamentos que ajudaram os estudantes a retomar explicações já em desenvolvimento, testar hipóteses e, assim, construir uma explicação para o problema. Como operação dos estudantes, as perguntas também colaboraram para o entendimento do problema e para o teste de hipótese que conduziram à sua resolução. Acreditamos que parte dessas perguntas, principalmente aquelas que visaram a destacar condições relevantes para execução da investigação durante o segundo momento da aula, pode ser caracterizada como Potenciais Problemas Significadores, ferramentas pedagógicas que permitem aos estudantes "significar qualitativamente os problemas didáticos presentes em atividades investigativas" (SOLINO, 2017, p. 110) a fim de que esses possam assumir para si um problema proposto. 
Em análise dessa mesma aula, Solino (2017) destaca, de modo similar ao compreendido aqui, que esses Potenciais Problemas Significadores estiveram presentes em turnos tanta da professora, como no turno 8, quando ela diz "então explica melhor como é que é assim? como é que é essa ideia?", quanto dos estudantes, como no turno 17, quando Fabrício propõe "E se colocasse uma corda no barco?". Para a autora, esses problemas emergiram das contradições e reflexões vividas durante o enfrentamento colaborativo do problema e orientaram a construção de entendimento pela turma, desempenhando, portanto, papel central na resolução do problema.

Iniciando a análise das normas, parece-nos coerente dizer que, a partir do instante em que o problema foi apresentado pela professora, a norma de fórum esteve posta, evidenciandose em operações de apresentação, crítica, revisão e justificativa de hipóteses. Como operação que não encontramos na apresentação de como essa norma se dá nas comunidades científicas, temos a repetição de hipótese que é solicitada pela professora ou mesmo realizada por essa ao parafrasear as hipóteses dos estudantes. Entendemos essa operação como própria da sala de aula, mas também particular dessa professora que, ao longo de toda atividade buscou garantir que as hipóteses fossem coletivamente trabalhadas.

Pelas operações que evidenciam as demais normas podemos, contudo, perceber diferentes maneiras como a sala se configurou como um espaço de apresentação, crítica e revisão de hipóteses durante a atividade analisada. Pela categoria de receptividade à crítica, por exemplo, podemos identificar períodos em que não houve acolhimento das avaliações feitas pela professora e pelos estudantes, como no início da aula quando algumas ideias foram apresentadas sem refletir as condições apontadas, ou já no final da atividade, quando os estudantes se dispersam e voltam a trazer ideias fiadas na lógica cotidiana. Esses períodos ocupam, todavia, a menor parte da aula de modo que, após o entendimento do problema, as críticas feitas passam a orientar a apresentação e revisão de hipóteses pela turma.

Com os padrões públicos de análise, podemos identificar, também, três grandes períodos. No primeiro deles, centrado nos dois primeiros momentos da aula, os critérios para apresentação de novas ideias são expostos pela professora que guia a construção de entendimento sobre o problema. No segundo período, que corresponde ao enfrentamento coletivo do problema, esses critérios parecem já estabelecidos como um conjunto que dá suporte às hipóteses em construção e, mesmo que não explicitados, podem ser assumidos como presentes, uma vez que o conteúdo das hipóteses apresentadas é coerente com padrões expostos. Por fim, no terceiro período, temos a retomada desses critérios em uma operação 
conduzida pela professora que avaliamos como a intenção de explicitar as informações disponíveis e as ideias já estabelecidas a fim de dar suporte à conclusão da explicação.

Concluindo a discussão das normas, temos a constituição de igualdade moderada evidenciada pela constante solicitação da professora para que hipóteses sejam apresentadas pelos estudantes e, por parte desses, pala apresentação, por vezes espontânea, de hipóteses, o que parece indicar que todos são considerados e se consideram igualmente capazes de contribuir. Reforçando essa hipótese, temos, inclusive, o reconhecimento dessa capacidade pela turma que solicita contribuições de um colega que acreditam ter encontrado a resposta, indicando que a igualdade é moderada pela compreensão que aquela comunidade tem sobre os níveis de conhecimento ou expertise de seus membros. Imaginamos, também, que é em decorrência dessa compreensão que, em outra situação, os estudantes pedem uma dica à professora, por considerarem que essa possui um conhecimento que eles não têm.

Entretanto, cabe destacar nessa discussão situações pontuais em que a professora interrompe ou ignora contribuições de estudantes, indicando que, por vezes, a igualdade entre estudantes e professora é relativizada pela autoridade dessa que busca um controle sobre a turma seja para apresentar uma atividade, seja para partilhar algumas hipóteses ou condições relevantes para execução da investigação.

Encerrando essas considerações preliminares, acreditamos que, conforme analisamos a implementação da primeira aula da SEI, encontramos elementos que nos permitem falar da constituição daquela sala de aula, ao menos durante essa atividade, como uma comunidade de práticas. Sustentamos essa hipótese na proposição de Lave e Wenger (1991) de que uma comunidade de práticas deve ser entendida como uma organização espontaneamente formada entre praticantes e caracterizada pelo engajamento mútuo, pela identificação com um projeto e pela partilha de um repertório. Essas características parecem-nos evidenciar-se na resolução colaborativa do problema (engajamento mútuo), na construção coletiva de entendimento e no replanejamento de novos rumos de execução da investigação (identificação com um projeto), bem como no reconhecimento de que o pensamento matemático deveria ser usado, nos sentidos criados e partilhados e nas regras implícitas que conduzem a participação em aula (partilha de um repertório).

\subsection{Aula 5 - Leitura e discussão de textos}


As duas atividades em análise nesta seção correspondem à sexta e à sétima atividades propostas na SEI e estão relacionadas ao "Problema do Barquinho" resolvido pelos estudantes na segunda atividade dessa mesma sequência. Realizada na segunda aula, "O Problema do Barquinho" propunha que, em pequenos grupos, os estudantes construíssem uma embarcação de papel alumínio capaz de carregar a maior carga (arruelas de ferro) possível sem afundar na água. $\mathrm{O}$ objetivo central da referida atividade era discutir duas variáveis imprescindíveis para a flutuação de corpos, o que os estudantes puderam observar ao levantar, testar e comparar hipóteses sobre (1) o tamanho das embarcações construídas e sobre (2) a quantidade e distribuição das peças carregadas. A partir das ideias construídas com a experiência prática, na aula que analisamos a seguir, os estudantes são apresentados ao lastro como recurso utilizado para manter a estabilidade de embarcações na água e à possibilidade de seres vivos serem transportados na água de lastro.

Optamos pela análise conjunta da sexta e da sétima atividade, pois essas foram agrupadas pela professora, tendo sido realizadas em uma única aula (cerca de 25 minutos registrado em vídeo) no dia 29 de outubro de 2012, quinto dia de trabalho com a SEI. O mapa abaixo apresenta o planejamento da sexta atividade - leitura e discussão do texto "Mantendo embarcações na água”.

\begin{tabular}{l|l|l}
\hline \multicolumn{1}{c|}{ Objetivos explicitados } & \multicolumn{1}{|c}{ Procedimentos de ensino } & \multicolumn{1}{c}{ Exercícios } \\
\hline $\begin{array}{l}\text { Apresentar os estudantes ao } \\
\text { lastro como recurso utilizado } \\
\text { para manter a estabilidade da } \\
\text { embarcação, estando ela } \\
\text { cheia ou desprovida de carga }\end{array}$ & $\begin{array}{l}\text { Realizar a leitura do texto } \\
\text { acompanhada da leitura das } \\
\text { imagens disponibilizadas aos } \\
\text { estudantes e discutir com os } \\
\text { estudantes de tal modo que } \\
\text { eles possam perceber a } \\
\text { alternância entre a inserção } \\
\text { de carga e de lastro em uma } \\
\text { embarcação }\end{array}$ & $\begin{array}{l}\text { Os estudantes devem } \\
\text { acompanhar a leitura } \\
\text { conduzida pela professora, } \\
\text { respondendo aos } \\
\text { questionamentos elaborados } \\
\text { por ela e destacando os } \\
\text { pontos mais importantes do } \\
\text { texto }\end{array}$ \\
& $\begin{array}{l}\text { Aproveitar o momento de } \\
\text { leitura para incentivar os } \\
\text { estudantes a destacarem o } \\
\text { que acharam mais importante } \\
\text { no texto }\end{array}$ & $\begin{array}{l}\text { Após a leitura, coletivamente, } \\
\text { os estudantes devem } \\
\text { responder aos seguintes } \\
\text { problemas: } \\
\text { 1. Um navio mercante } \\
\text { aportou no porto de Bilbao, } \\
\text { na Espanha, carregado de } \\
\text { frutas do vale do São } \\
\text { Francisco, na Bahia e em } \\
\text { Pernambuco. Após } \\
\text { Ainda durante a leitura, } \\
\text { propor algumas questões } \\
\text { problematizadoras para } \\
\text { incentivar a leitura }\end{array}$ \\
& & $\begin{array}{l}\text { o navio não tinha carga } \\
\text { para retornar ao Brasil. Que }\end{array}$ \\
\hline
\end{tabular}




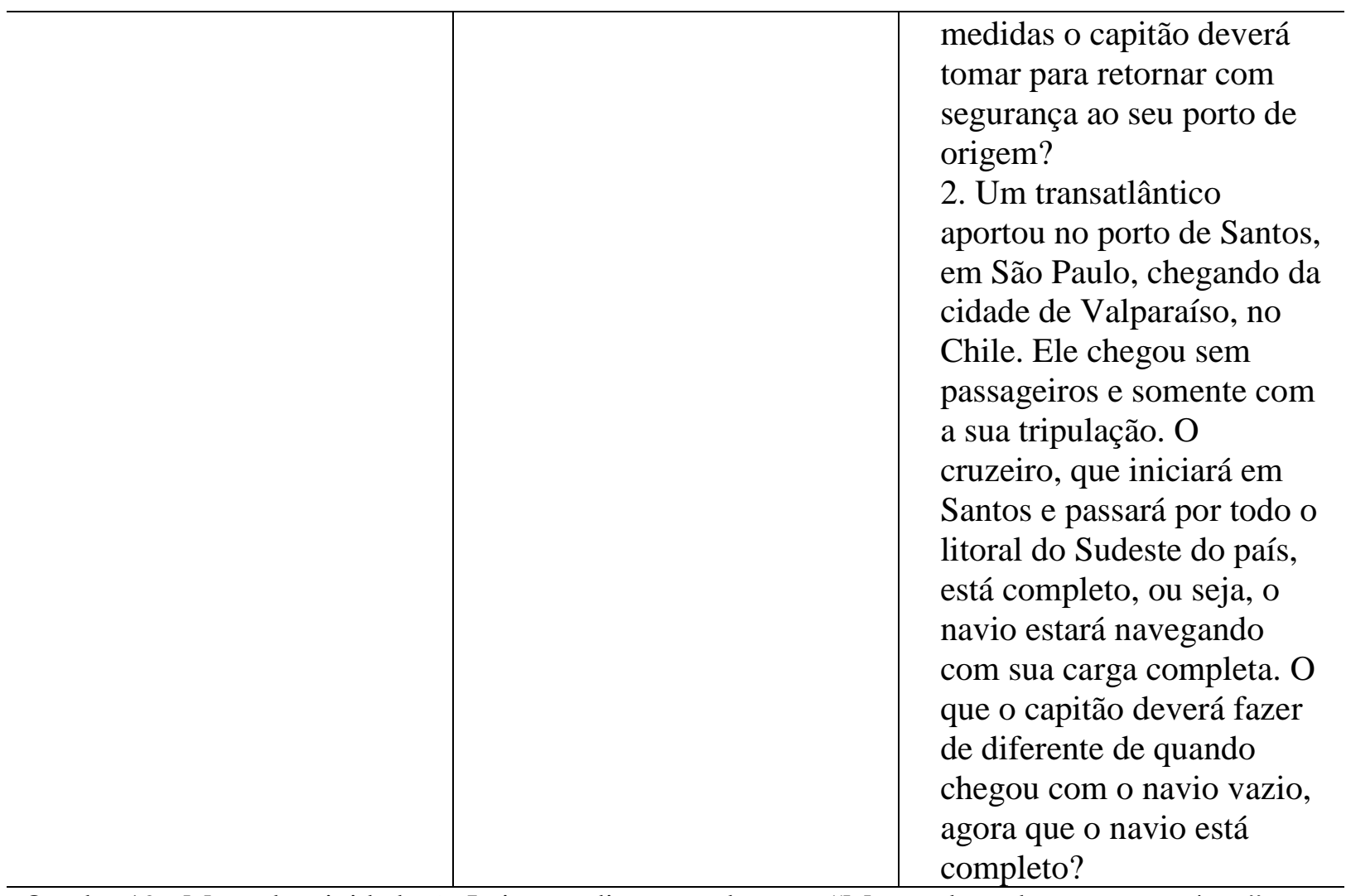

Quadro 19 - Mapa da atividade 6 - Leitura e discussão do texto "Mantendo embarcações na água"

Aplicada na mesma aula, para a atividade 7 - Leitura e discussão do texto "Vida marinha na água de lastro", a professora recebeu a seguinte estratégia:

\begin{tabular}{|c|c|c|}
\hline Objetivos explicitados & Procedimentos de ensino & Exercícios \\
\hline $\begin{array}{l}\text { Apresentar aos estudantes a } \\
\text { possibilidade de seres vivos } \\
\text { serem transportados na água } \\
\text { de lastro } \\
\text { Levar a turma a levantar } \\
\text { hipóteses sobre as relações } \\
\text { entre seres vivos para que } \\
\text { depois seja possível discutir a } \\
\text { extinção }\end{array}$ & $\begin{array}{l}\text { Realizar a leitura do texto } \\
\text { acompanhada da leitura das } \\
\text { imagens disponibilizadas aos } \\
\text { estudantes } \\
\text { Após a leitura, discutir com } \\
\text { os estudantes o que eles } \\
\text { imaginam que pode ser } \\
\text { inserido junto com a água nos } \\
\text { tanques de lastro e o que } \\
\text { pode ocorrer com um ser } \\
\text { vivo que, porventura, tenha } \\
\text { sido colocado dentro de um } \\
\text { desses tanques } \\
\text { Durante essa discussão, } \\
\text { estimular todos os estudantes } \\
\text { a falar }\end{array}$ & $\begin{array}{l}\text { Os estudantes devem } \\
\text { acompanhar a leitura } \\
\text { conduzida pela professora, } \\
\text { respondendo aos } \\
\text { questionamentos elaborados } \\
\text { por ela e destacando os } \\
\text { pontos mais importantes do } \\
\text { texto } \\
\text { Após a leitura, coletivamente, } \\
\text { os estudantes devem resolver } \\
\text { à seguinte questão: } \\
\text { O que você acha que } \\
\text { acontece com seres vivos } \\
\text { marinhos que são } \\
\text { despejados em um local } \\
\text { com condições climáticas } \\
\text { adequadas, com muito } \\
\text { alimento e longe de seus } \\
\text { predadores? }\end{array}$ \\
\hline
\end{tabular}


Ao final da discussão, cada estudante deve escrever e/ou desenhar a solução do problema no seu caderno

Quadro 20 - Mapa da atividade 7 - Leitura e discussão do texto "Vida marinha na água de lastro"

Conforme sintetizado nos mapas acima, com perfis bastante similares, as duas atividades parecem prever o trabalho com as quatro dimensões que, como proposto por Stroupe (2015) e adotado para este trabalho, devem compor os objetivos para o ensino de ciências como prática. Contemplando a dimensão conceitual, temos a apresentação do conceito de lastro e do uso da água como recurso para manutenção da estabilidade das embarcações. Complementarmente, ainda contemplando essa dimensão, temos a indicação de que a possibilidade de seres vivos serem transportados na água de lastro seja discutida.

Como orientação que permite a experiência da dimensão social, temos na SEI que conteúdos devem ser trabalhados de forma colaborativa em um processo de construção, comunicação e apreciação de explicações científicas para os problemas que serão apresentados pela professora. Nesse processo, as explicações a serem elaboradas devem estar sustentadas em informações de textos e nas imagens disponibilizados aos grupos, permitindo aos estudantes o contato com termos e linguagens específicas e promovendo a dimensão material. Também compondo um objetivo referente a essa dimensão, é previsto o registro em caderno.

Por fim, na indicação de que os estudantes devem apresentar hipóteses sobre o que eles imaginam que pode ser inserido junto com a água nos tanques de lastro e sobre o que pode ocorrer com um ser vivo que, porventura, tenha sido colocado dentro de um desses tanques, identificamos possibilidade de que a sala vivencia a dimensão epistêmica do trabalho científico, à medida em que sejam criadas oportunidades para que eles explicitem porque as hipóteses apresentadas são viáveis, comparem e critiquem hipóteses com seus colegas e estabeleçam critérios para definir o que será considerado como válido.

Quando implementadas, as atividades aconteceram na própria sala de aula do terceiro ano. Naquele momento, as carteiras estavam organizadas em agrupamentos de quatro e cada estudante possuía material impresso onde o texto lido pela professora poderia ser acompanhado (anexo B). Além do texto, cada grupo possuía uma ficha com ilustrações que representavam a vista em corte lateral de um navio cargueiro nos momentos de recebimento e 
retirada de carga (anexo C). Durante toda a atividade a professora esteve de pé próxima à região central da lousa.

$\mathrm{Na}$ figura abaixo, representamos a sala, tal como pode ser vista no vídeo, identificando os conjuntos de quatro carteiras pelos retângulos maiores e as cadeiras pelos retângulos menores pretos. Os retângulos menores em branco indicam três cadeiras que estavam desocupadas e as áreas em cinza identificam os pontos da sala que não são capturados ao longo da filmagem.

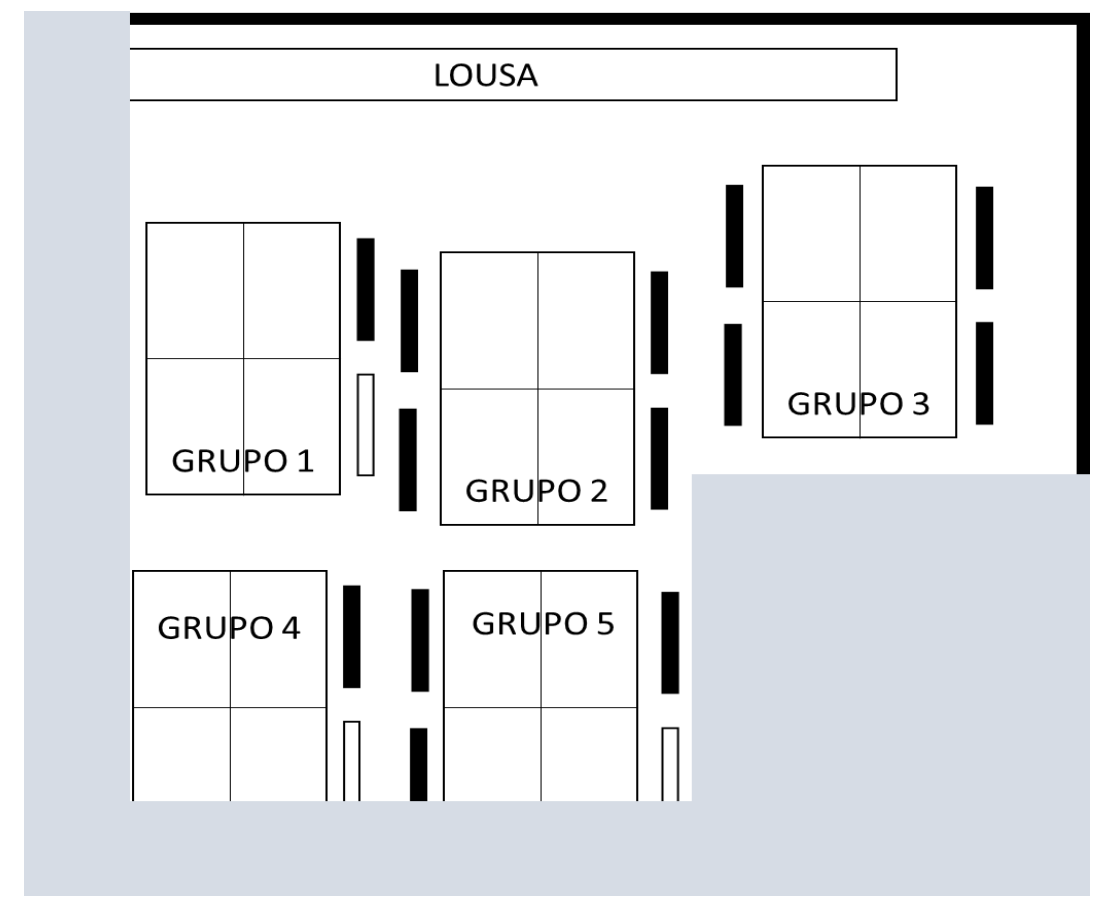

Figura 6 - Representação gráfica da sala, conforme registro em vídeo, durante a Aula 5 - Leitura e discussão de textos

A gravação desta aula tem início quando os estudantes já estão sentados em grupos e a professora, em tom de voz elevado, pede que todos façam silêncio para que a atividade de leitura possa acontecer sem interrupções. Em uma visão geral, podemos dizer que, a partir do proposto na SEI, a condução da aula se dá em quatro momentos, sendo: 


\section{A RETOMADA DE ATIVIDADES ANTERIORES}

- Contextualizar atividade

A LEITURA E DISCUSSÃO DO PRIMEIRO TEXTO

- Realizar a leitura do texto em voz alta

- Analisar as ilustrações à luz do texto lido

- Adaptar os problemas propostos

A LEITURA E DISCUSSÃO DO SEGUNDO TEXTO

- Problematizar o texto

A CONDUÇÃO DE SÍNTESE DAS DISCUSSÕES

- Sintetizar as ideias

Figura 7 - Momentos e episódios da Aula 5 - Leitura e discussão de textos

\subsubsection{Retomada de atividades anteriores}

A aula se inicia com a retomada do que fora trabalhado nas aulas anteriores durante a resolução e discussão do "Problema do barquinho" (atividades 2 e 3), mas também com a leitura e discussão do texto "Diferentes barcos para diferentes usos" (atividade 4) que trouxe informações sobre a diversidade de formatos e finalidades das embarcações. 
Contextualizar a atividade

\begin{tabular}{|c|c|c|c|c|c|}
\hline \multirow[b]{2}{*}{$\begin{array}{l}\text { Turnos } \\
\left(1 ' 22^{\prime \prime}-2{ }^{\prime} 58^{\prime \prime}\right)\end{array}$} & \multicolumn{3}{|c|}{ Evidências de Normas Culturais } & \multicolumn{2}{|c|}{ Evidências de Práticas Culturais } \\
\hline & Fórum & $\begin{array}{l}\text { Padrões Públicos } \\
\text { de Análise }\end{array}$ & $\begin{array}{l}\text { Igualdade } \\
\text { Moderada }\end{array}$ & Fazer Perguntas & $\begin{array}{c}\text { Planejar e } \\
\text { Executar } \\
\text { Investigações }\end{array}$ \\
\hline $\begin{array}{l}\text { 17. Professora: Peixe... cargas né? as } \\
\text { embarcações podem carregar pessoas ou cargas } \\
\text { né? de VÁRIAS coisas... muitas coisas } \\
\text { diferentes... e vocês receberam um texto aí... e } \\
\text { agora nós vamos falar sobre como as } \\
\text { embarcações se mantêm na água... vocês } \\
\text { lembram da experiência do barquinho? o que é } \\
\text { que fazia o barquinho flutuar direitinho com a } \\
\text { carga? hã? }\end{array}$ & $\begin{array}{l}\text { professora repete } \\
\text { hipóteses }\end{array}$ & & $\begin{array}{l}\text { professora solicita } \\
\text { contribuições }\end{array}$ & $\begin{array}{l}\text { professora faz } \\
\text { perguntas para } \\
\text { retomar o que já é } \\
\text { conhecido }\end{array}$ & \\
\hline \multicolumn{6}{|l|}{ 18. Estudante: (inaudível) } \\
\hline $\begin{array}{l}\text { 19. Professora: Não... a experiência com as } \\
\text { pecinhas de ferro... por que que afundava? }\end{array}$ & $\begin{array}{l}\text { professora critica } \\
\text { hipóteses }\end{array}$ & \multirow{6}{*}{$\begin{array}{l}\text { professora e } \\
\text { estudantes } \\
\text { retomam } \\
\text { conhecimentos já } \\
\text { estabelecidos para } \\
\text { apresentação de } \\
\text { novas ideias }\end{array}$} & $\begin{array}{l}\text { professora rejeita } \\
\text { contribuições }\end{array}$ & $\begin{array}{c}\text { professora faz } \\
\text { perguntas para } \\
\text { retomar o que já é } \\
\text { conhecido }\end{array}$ & \multirow{6}{*}{$\begin{array}{c}\text { professora e } \\
\text { estudantes } \\
\text { identificam } \\
\text { conhecimentos já } \\
\text { estabelecidos pelo } \\
\text { grupo }\end{array}$} \\
\hline 20. Maria: O peso... todo de um lado. & $\begin{array}{l}\text { estudantes } \\
\text { apresentam } \\
\text { hipóteses }\end{array}$ & & $\begin{array}{c}\text { estudantes } \\
\text { apresentam } \\
\text { contribuições } \\
\end{array}$ & & \\
\hline $\begin{array}{l}\text { 21. Professora: Isso... quando o peso estava só de } \\
\text { um lado o que acontecia? }\end{array}$ & & & $\begin{array}{l}\text { professora solicita } \\
\text { contribuições }\end{array}$ & $\begin{array}{c}\text { professora faz } \\
\text { perguntas para } \\
\text { retomar o que já é } \\
\text { conhecido }\end{array}$ & \\
\hline 22. Estudantes: Afundava & $\begin{array}{c}\text { estudantes } \\
\text { apresentam } \\
\text { hipóteses } \\
\end{array}$ & & $\begin{array}{c}\text { estudantes } \\
\text { apresentam } \\
\text { contribuições } \\
\end{array}$ & & \\
\hline $\begin{array}{l}\text { 23. Professora: Então o que é que fazia o barco } \\
\text { ficar legal lá na água? }\end{array}$ & & & $\begin{array}{l}\text { professora solicita } \\
\text { contribuições }\end{array}$ & $\begin{array}{c}\text { professora faz } \\
\text { perguntas para } \\
\text { retomar o que já é } \\
\text { conhecido }\end{array}$ & \\
\hline $\begin{array}{l}\text { 24. Estudantes: Tinha que colocar lá no outro } \\
\text { lado }\end{array}$ & $\begin{array}{l}\text { estudantes } \\
\text { apresentam }\end{array}$ & & $\begin{array}{l}\text { estudantes } \\
\text { apresentam }\end{array}$ & & \\
\hline
\end{tabular}




\begin{tabular}{|c|c|c|c|c|}
\hline & hipóteses & contribuições & & \\
\hline $\begin{array}{l}\text { 25. Professora: Tinha que distribuir as peças né? e } \\
\text { isso acontece com qualquer embarcação... se } \\
\text { colocar muita carga... de qualquer jeito... o que é } \\
\text { que vai acontecer? }\end{array}$ & $\begin{array}{c}\text { professora repete } \\
\text { hipóteses } \\
\text { professora } \\
\text { apresenta } \\
\text { hipóteses } \\
\end{array}$ & $\begin{array}{l}\text { professora solicita } \\
\text { contribuições }\end{array}$ & $\begin{array}{l}\text { professora faz } \\
\text { perguntas para } \\
\text { retomar o que já é } \\
\text { conhecido }\end{array}$ & \\
\hline 26. Estudantes: Vai afundar. & $\begin{array}{l}\text { estudantes } \\
\text { apresentam } \\
\text { hipóteses }\end{array}$ & $\begin{array}{c}\text { estudantes } \\
\text { apresentam } \\
\text { contribuições }\end{array}$ & & \\
\hline
\end{tabular}

Quadro 21 - Episódio 1- Atividade 6- Leitura e discussão do texto "Mantendo embarcações na água" - 29/10/2012 
No primeiro momento da aula, a sala está envolvida em uma revisão de atividades realizadas anteriormente e identificamos algumas evidências de quais normas estão vigentes no momento. Como primeira delas, podemos falar do fórum que aqui não se estabelece pela apresentação de hipóteses para resolução de um problema, mas pela retomada e discussão de alguns conhecimentos já estabelecidos no grupo e que servirão de ponto de partida para resolução dos problemas apresentados na presente aula. Nesse sentido, ainda que não tenhamos um problema posto, vemos se configurar um espaço de apresentação e revisão de ideias.

Em virtude da escolha da professora por realizar essa revisão coletivamente e dada a espontaneidades com que as contribuições são apresentadas, acreditamos poder dizer que há igualdade moderada durante esse episódio, sendo que, tanto professora, quanto os estudantes são considerados capazes de contribuir com a retomada de algumas das discussões previamente realizadas. Essa igualdade, todavia, é marcada por uma condução da professora que busca relembrar apenas os tópicos relacionados aos problemas que serão propostos na aula, como podemos ver no turno 19, quando a professora rejeita uma contribuição inaudível, mas que remete a alguma situação que não seja "a experiência com as pecinhas de ferro".

Esse processo de revisão evidencia uma operação que ainda não aparecera dentro da norma de padrões públicos de análise: retomar conhecimentos já estabelecidos para apresentação de novas ideias. Se, nas comunidades científicas, a necessidade da norma de padrões públicos de análise está relacionada ao estabelecimento de um conjunto de critérios e conhecimentos estabelecidos que organizam e dão suporte a proposições e ao exame e revisão dessas, em sala de aula, a professora conduz a retomada das atividades e, com isso, pode auxiliar os estudantes a organizar alguns conhecimentos que serão importantes para sustentar a apresentação de explicações para o problema que será proposto.

Para conduzir essa retomada das atividades anteriores, a professora faz perguntas à turma que, de modo similar ao realizado em comunidades científicas, cumprem a função de identificar o que já é conhecido para, a partir disso, desenvolver, revisar ou propor explicações. Todo esse trabalho de construção de bases para a investigação que será proposta evidencia, também, o planejar e executar investigações que aproxima a prática escolar à das comunidades cientificas nas quais a produção do conhecimento é sustentada em esquemas, quadros, documentos, artigos e outras formas de registro que permitam rever o conhecimento já elaborado (LATOUR; WOOLGAR, 1997). 
5.2.2 Leitura e discussão do primeiro texto

O segundo momento dessa aula compreende a leitura e discussão do texto "Mantendo embarcação na água", sendo composto por alguns turnos longos referentes à leitura em voz alta conduzida pela professora. Para facilitar a análise, como será visto nos dois episódios iniciais deste momento, dividimos esses turnos em alguns blocos, conforme as pausas realizadas na leitura. 
Realizar a leitura do texto em voz alta

\begin{tabular}{|c|c|c|c|}
\hline \multirow[b]{2}{*}{$\begin{array}{l}\text { Turnos } \\
\left(3{ }^{\prime} 10{ }^{\prime}-6{ }^{\prime} 12 ”\right)\end{array}$} & \multirow{2}{*}{$\begin{array}{c}\text { Evidências de } \\
\text { Normas Culturais } \\
\text { Igualdade Moderada }\end{array}$} & \multicolumn{2}{|c|}{ Evidências de Práticas Culturais } \\
\hline & & $\begin{array}{c}\text { Planejar e } \\
\text { Executar } \\
\text { Investigações } \\
\end{array}$ & $\begin{array}{l}\text { Obter, Avaliar e } \\
\text { Comunicar } \\
\text { Informações } \\
\end{array}$ \\
\hline $\begin{array}{l}\text { 31a. Professora: Nós vamos começar a leitura... "Mantendo navios na água"... para } \\
\text { acompanhar agora... tá? Adriano! "Acabamos de ver que os barcos podem ser utilizados } \\
\text { como meio de transporte, tanto para cargas em geral"... Diego ainda é o texto... eu ainda não } \\
\text { pedi para pegar a ilustração... por favor... pegue o texto... }\end{array}$ & $\begin{array}{l}\text { professora chama } \\
\text { atenção de } \\
\text { estudantes }\end{array}$ & $\begin{array}{l}\text { professora solicita } \\
\text { que estudantes } \\
\text { peguem materiais }\end{array}$ & $\begin{array}{l}\text { professora lê } \\
\text { informações de } \\
\text { textos }\end{array}$ \\
\hline $\begin{array}{l}\text { 31b. "Devemos estar sempre atentos para a capacidade de carga de uma embarcação, pois o } \\
\text { excesso pode implicar no seu AFUNDAMENTO devido ao grande peso e a falta de carga } \\
\text { também pode resultar em problema já que o navio fica instável, ou seja, não se mantém } \\
\text { equilibrado sobre a água e pode tombar." ...isso quer dizer que o navio vazio... ele fica muito } \\
\text { leve e também pode... ((faz gestos com as mãos balançando de um lado para o outro } \\
\text { mostrando a instabilidade do navio)) tombar esse navio ou essa embarcação.... então... a falta } \\
\text { de peso Fabrício... também pode prejudicar a embarcação... }\end{array}$ & $\begin{array}{l}\text { professora chama } \\
\text { atenção de } \\
\text { estudantes }\end{array}$ & $\begin{array}{l}\text { professora mapeia } \\
\text { condições } \\
\text { relevantes }\end{array}$ & $\begin{array}{l}\text { professora lê } \\
\text { informações de } \\
\quad \text { textos } \\
\text { professora destaca } \\
\text { informações de } \\
\quad \text { textos }\end{array}$ \\
\hline $\begin{array}{l}\text { 31c. "Para evitar que as embarcações tenham o problema de falta de estabilidade, os navios } \\
\text { são providos de tanques onde é colocado o chamado Lastro." ... tanque de Lastro... vamos ver } \\
\text { o que é isso... }\end{array}$ & & $\begin{array}{l}\text { professora mapeia } \\
\text { condições } \\
\text { relevantes }\end{array}$ & $\begin{array}{l}\text { professora lê } \\
\text { informações de } \\
\text { textos }\end{array}$ \\
\hline \multicolumn{4}{|l|}{ 32. Ariel: Eu leio lasto? } \\
\hline $\begin{array}{l}\text { 33a. Professora: Lastro ((professora escreve na lousa a expressão tanque de lastro)) olha... } \\
\text { agora vem a explicação... FABRÍCIO... }\end{array}$ & $\begin{array}{l}\text { professora chama } \\
\text { atenção de } \\
\text { estudantes }\end{array}$ & & $\begin{array}{l}\text { professora destaca } \\
\text { informações de } \\
\text { textos }\end{array}$ \\
\hline $\begin{array}{l}\text { 33b. "É o nome dado a qualquer material usado para dar estabilidade e equilíbrio ao navio. } \\
\text { Antigamente eram usados materiais sólidos, como pedras, por exemplo, mas muitas } \\
\text { dificuldades apareciam quando era necessário retirar o lastro para colocar A CARGA no } \\
\text { navio. Hoje em dia o lastro de embarcações modernas é feito com ÁGUA. Bombas colocam e } \\
\text { retiram água dos tanques dos navios garantindo estabilidade para que possam seguir viagem. } \\
\text { Cuidados especiais tem que ser tomados ao se colocar ou ao se retirar o lastro dos tanques. } \\
\text { No momento que a carga é retirada da embarcação, as bombas injetam água nos tanques para } \\
\text { que elas continuem estáveis sobre a água. O inverso acontece quando a carga é colocada na } \\
\text { embarcação, a água é retirada para que o navio não fique muito pesado e afunde."... }\end{array}$ & & $\begin{array}{l}\text { professora mapeia } \\
\text { condições } \\
\text { relevantes }\end{array}$ & $\begin{array}{l}\text { professora lê } \\
\text { informações de } \\
\quad \text { textos } \\
\text { professora destaca } \\
\text { informações de } \\
\quad \text { textos }\end{array}$ \\
\hline
\end{tabular}

Quadro 22 - Episódio 2- Atividade 6- Leitura e discussão do texto "Mantendo embarcações na água" - 29/10/2012 
No episódio que inicia a análise do segundo momento desta aula, vemos a professora realizar a leitura de um texto em voz alta, entrecortando seu turno com explicações verbais e gestuais. Essa “dinâmica de ler um texto, parágrafo por parágrafo, interrompendo e explicando é um dos modos mais recorrentes e intuitivos dos professores realizarem leitura de texto didático em classe" (SILVEIRA JUNIOR; LIMA; CASTRO; MACHADO, 2015, p. 643) e é, inclusive, indicada na SEI quando sugere-se que, durante a leitura, sejam propostas questões problematizadoras para incentivar a leitura. Recomendações similares podem ser encontradas em outras orientações sobre o ensino de ciências, como nas indicações do NRC (2011) nas quais defende-se a leitura acompanhada como operação necessária nos anos iniciais de escolarização, posto que, mesmo para os estudantes já alfabetizados, os gêneros científicos trazem particularidades desafiadoras como termos pouco usuais ou ferramentas de um repertório específico ainda não dominado, tais como diagramas, gráficos e símbolos matemáticos. Tendo isso em vista, acreditamos que, ao trazer explicações durante a leitura, a professora pretende criar mais condições para que o texto seja utilizado pela turma durante o enfrentamento dos problemas que serão propostos e, portanto, optamos por categorizar essas operações como evidências da prática de obter, avaliar e comunicar informações que envolve a leitura e a interpretação de textos científicos que, no contexto escolar, podem ser explorados, inicialmente, com ajuda.

Para ilustrar as maneiras de destacar informações utilizadas pela professora, trazemos o turno 31 b quando, ao falar que "devemos estar sempre atentos para a capacidade de carga de uma embarcação, pois o excesso pode implicar no seu AFUNDAMENTO devido ao grande peso", a professora ressalta, pela entonação de voz, um aspecto central no texto que é a relação entre a capacidade de carga e a manutenção da flutuação da embarcação. Uma operação similar pode ser vista no turno 33b, quando a professora destaca a relação entre o uso da água como lastro e a entrada e retirada de carga. Como outra maneira de guiar a leitura do texto, no turno $33 \mathrm{~b}$ a professora destaca por meio de gestual o movimento de instabilidade da embarcação que pode tombar sem lastro e, em seguida, a vista em corte lateral do navio representado na ilustração. Compondo esse conjunto de operações, no turno 33a, a professora registra em lousa e chama atenção para a expressão "tanque de lastro" que será central para compreensão dos textos dessa aula e para resolução dos problemas propostos.

Em outros momentos da aula (apêndice B), podemos identificar operações similares da professora e que atendem ao mesmo fim de comunicar informações durante a leitura e interpretação do texto, como o uso de uma analogia para explicar o mecanismo de funcionamento das bombas do navio, comparando-as com as bombas de piscina. Esse 
equipamento. possivelmente mais conhecido pelos estudantes, é responsável por impulsionar a água e fazer com que ela circule, desempenhado, portanto, função semelhante à descrita no texto.

Com essas intervenções, a professora destaca quais das informações disponíveis no texto não podem deixar de ser consideradas para execução da investigação, mapeando condições relevantes para construção de explicações para os problemas que serão propostos. Essa operação, junto com a indicação das tarefas e materiais a serem utilizados caracterizam a prática de planejar e executar investigações nesse momento. Para exemplificar o planejamento do modo de trabalho e dos materiais a serem utilizados, podemos destacar o turno 31a, quando a professora diz para Diego não mexer na ilustração disponível para o grupo, indicando que ela já traçou etapas para essa aula que se iniciam pela leitura do texto e, em seguida, passam pela interpretação das ilustrações, o que é confirmado, no episódio que segue, quando é solicitado que os estudantes peguem o material impresso e observem as ilustrações a fim de obter as informações necessárias para responder às perguntas formuladas.

Enfocando as normas, podemos falar que durante o momento de leitura e a interpretação do texto a constituição de igualdade moderada apresenta características distintas. Conforme definido para este trabalho, para configuração dessa norma, é necessário que exista igualdade de autoridade intelectual em sala, relativizada por níveis de expertise ou conhecimento, entretanto, no episódio acima, ao conduzir a leitura, a professora parece tentar manter a atenção de toda a turma por meio de intervenções disciplinares que indicam que os estudantes devem trabalhar juntos (turno 31a) e em silêncio (turnos 31 b e 33a). Consideramos essas intervenções como evidências de que, no primeiro episódio deste momento, a igualdade é moderada por uma relação vertical de poder entre professora e estudantes, de modo que não caracterizamos, ainda, a presença da norma em sala. Já no episódio que segue, quando as contribuições passam a ser solicitadas e apresentadas, temos as primeiras evidências de constituição de igualdade moderada no segundo momento da aula.

Ainda com o episódio acima, aproveitamos para ressaltar que, na SEI, é sugerido que a professora aproveite o momento de leitura para incentivar os estudantes a destacar o que acharam mais importante no texto e para propor algumas questões problematizadoras a fim de incentivar a leitura, mas isso não ocorre nessa aula como consequência da opção da professora por centralizar a leitura e a interpretação do texto, destacando e explicando, ela mesma, as informações centrais. Ao fazer isso, a professora deixa de criar condições para que hipóteses sejam levantadas, testadas, avaliadas e revistas coletivamente, o que parece-nos comprometer 
o caráter investigativo da atividade e também a possibilidade de identificação do grupo com o projeto, elemento necessário para constituição da sala como uma comunidade de práticas.

Considerando o que Wenger (2016) propõe sobre as comunidades de prática, para promoção da identificação com um projeto, é importante que, durante a negociação de sentidos, que poderia ser promovida pela leitura e interpretação coletiva do texto, exista protagonismo dos estudantes e oportunidades para que esses estipulem normas de participação no debate e estabeleçam critérios para definir aquilo que é mais relevante para o enfrentamento do problema, optando por quais informações devem ser adotadas ou descartadas. No entanto, quando a professora altera o procedimento apresentado na SEI, possivelmente, cria menos condições para que isso ocorra.

A seguir, dando sequência à discussão do texto, destacamos um episódio no qual percebemos evidências de que a sala poderá se configurar como um fórum para apresentação e debate de hipóteses sobre o que fora lido. A instauração dessa possibilidade se dá quando a professora, como proposto na SEI, traz uma problematização a fim de discutir com os estudantes a alternância entre a inserção de carga e de lastro nas embarcações, perguntando "e se o navio tiver vazio e muito leve... o que é que eles vão fazer então?”. Essa pergunta é respondida por Fabrício e explorada pela professora e demais estudantes. 
Analisar as ilustrações à luz do texto lido

\begin{tabular}{|c|c|c|c|c|c|c|}
\hline \multirow{2}{*}{$\begin{array}{l}\text { Turnos } \\
\left(8,22^{\prime},-96^{\prime} 16^{\prime \prime}\right)\end{array}$} & \multicolumn{2}{|c|}{$\begin{array}{c}\text { Evidências de Normas } \\
\text { Culturais }\end{array}$} & \multicolumn{4}{|c|}{ Evidências de Práticas Culturais } \\
\hline & Fórum & $\begin{array}{l}\text { Igualdade } \\
\text { moderada }\end{array}$ & Fazer perguntas & $\begin{array}{c}\text { Planejar e } \\
\text { executar } \\
\text { investigações }\end{array}$ & $\begin{array}{l}\text { Construir } \\
\text { Explicações }\end{array}$ & $\begin{array}{c}\text { Obter, avaliar e } \\
\text { comunicar } \\
\text { informações }\end{array}$ \\
\hline $\begin{array}{l}\text { 39. Professora: Encher de novo com a água } \\
\text { Fabrício... tá? é isso mesmo Fabrício... então se o } \\
\text { navio está com muita carga a bomba tira a água lá } \\
\text { do porão... né? do tanque de lastro... e se o navio } \\
\text { estiver vazio... já estiver deixado a carga lá... o que } \\
\text { é que acontece? o navio chegou... deixou a carga... } \\
\text { está vazio... está leve o que é que eles fazem para } \\
\text { sair? o que é que está acontecendo aí na segunda } \\
\text { figura? }\end{array}$ & $\begin{array}{l}\text { professora } \\
\text { repete } \\
\text { hipóteses }\end{array}$ & $\begin{array}{c}\text { professora } \\
\text { solicita } \\
\text { contribuições }\end{array}$ & $\begin{array}{c}\text { professora faz } \\
\text { perguntas para } \\
\text { guiar a } \\
\text { construção de } \\
\text { explicações }\end{array}$ & $\begin{array}{c}\text { professora } \\
\text { solicita que } \\
\text { estudantes } \\
\text { peguem } \\
\text { materiais }\end{array}$ & $\begin{array}{c}\text { professora } \\
\text { solicita que } \\
\text { estudantes } \\
\text { apresentem } \\
\text { hipóteses }\end{array}$ & $\begin{array}{c}\text { professora } \\
\text { solicita que } \\
\text { estudantes } \\
\text { interpretem } \\
\text { informações }\end{array}$ \\
\hline $\begin{array}{l}\text { 40. Maria: O barco está afundando porque está } \\
\text { leve }\end{array}$ & $\begin{array}{l}\text { estudantes } \\
\text { apresentam } \\
\text { hipóteses }\end{array}$ & $\begin{array}{c}\text { estudantes } \\
\text { apresentam } \\
\text { contribuições }\end{array}$ & & & $\begin{array}{c}\text { estudantes } \\
\text { apresentam } \\
\text { hipóteses } \\
\text { incoerentes }\end{array}$ & $\begin{array}{c}\text { estudantes } \\
\text { interpretam } \\
\text { informações }\end{array}$ \\
\hline $\begin{array}{l}\text { 41. Professora: É... o que está escrito aí na segunda } \\
\text { figura? }\end{array}$ & & & $\begin{array}{c}\text { professora faz } \\
\text { perguntas para } \\
\text { guiar a } \\
\text { construção de } \\
\text { explicações }\end{array}$ & $\begin{array}{c}\text { professora } \\
\text { solicita que } \\
\text { estudantes } \\
\text { peguem } \\
\text { materiais } \\
\end{array}$ & & $\begin{array}{l}\text { professora } \\
\text { solicita que } \\
\text { estudantes } \\
\text { comuniquem } \\
\text { informações }\end{array}$ \\
\hline $\begin{array}{l}\text { 42. Estudante: O barco está afundando porque está } \\
\text { leve }\end{array}$ & $\begin{array}{l}\text { estudantes } \\
\text { apresentam } \\
\text { hipóteses }\end{array}$ & $\begin{array}{c}\text { estudantes } \\
\text { apresentam } \\
\text { contribuições }\end{array}$ & & & $\begin{array}{c}\text { estudantes } \\
\text { apresentam } \\
\text { hipóteses } \\
\text { incoerentes }\end{array}$ & $\begin{array}{l}\text { estudantes } \\
\text { interpretam } \\
\text { informações }\end{array}$ \\
\hline $\begin{array}{l}\text { 43. Professora: NÃO lê o que está escrito aí na } \\
\text { segunda figura }\end{array}$ & & $\begin{array}{l}\text { professora } \\
\text { rejeita } \\
\text { contribuições }\end{array}$ & & $\begin{array}{c}\text { professora } \\
\text { solicita que } \\
\text { estudantes } \\
\text { peguem } \\
\text { materiais } \\
\end{array}$ & & $\begin{array}{l}\text { professora } \\
\text { solicita que } \\
\text { estudantes } \\
\text { comuniquem } \\
\text { informações }\end{array}$ \\
\hline 44. Estudante: (inaudível) cheio de água de lastro & & $\begin{array}{l}\text { estudantes } \\
\text { apresentam }\end{array}$ & & & & $\begin{array}{l}\text { estudantes } \\
\text { comunicam }\end{array}$ \\
\hline
\end{tabular}




\begin{tabular}{|c|c|c|c|c|c|}
\hline & & contribuições & & & informações \\
\hline $\begin{array}{l}\text { 45. Professora: Tanque de lastro o quê? você não } \\
\text { terminou de ler.... cheio.... se está sem carga o } \\
\text { tanque de lastro tem que estar? }\end{array}$ & & $\begin{array}{l}\text { professora } \\
\text { solicita } \\
\text { contribuições }\end{array}$ & $\begin{array}{c}\text { professora faz } \\
\text { perguntas para } \\
\text { guiar a } \\
\text { construção de } \\
\text { explicações }\end{array}$ & & $\begin{array}{c}\text { professora } \\
\text { solicita que } \\
\text { estudantes } \\
\text { comuniquem } \\
\text { informações }\end{array}$ \\
\hline 46. Maria: Cheio. & $\begin{array}{l}\text { estudantes } \\
\text { apresentam } \\
\text { hipóteses }\end{array}$ & $\begin{array}{l}\text { estudantes } \\
\text { apresentam } \\
\text { contribuições }\end{array}$ & & $\begin{array}{l}\text { estudantes } \\
\text { apresentam } \\
\text { hipóteses } \\
\text { coerente }\end{array}$ & $\begin{array}{l}\text { estudantes } \\
\text { comunicam } \\
\text { informações }\end{array}$ \\
\hline
\end{tabular}

Quadro 23 - Episódio 3- Atividade 6- Leitura e discussão do texto "Mantendo embarcações na água" - 29/10/2012 
Pela análise das colunas das normas, podemos perceber evidências da constituição de um fórum em sala no qual as ideias são apresentadas, porém, quando uma hipótese incoerente é trazida por Maria e outro colega (turnos 40 e 42), a avaliação da professora não é feita pela apresentação de padrões públicos de análise. Ou seja, no lugar de estabelecer com a turma o conjunto de critérios e conhecimentos a serem utilizados para construção de uma explicação, a professora rejeita uma contribuição e indica que os estudantes devem ler a legenda das ilustrações de modo que, neste momento, as hipóteses são apresentadas, mas não analisadas. Associamos a ausência dessa norma às maneiras como as práticas de fazer perguntas e construir explicações irão se constituir ao longo do episódio acima.

Iniciando pelo fazer perguntas, destacamos que, no turno 39, a professora formula um questionamento e indica que esse deve ser respondido pela interpretação da ilustração ao indagar "o que é que está acontecendo aí na segunda figura?". Frente à resposta de Maria, a professora tenta guiar a construção de explicações, indicando aos estudantes que leiam a legenda (turno 41), o que é reforçado nos turnos 43 e 45 quando, após ouvir a hipótese de Maria ser repetida por outro estudante, a professora insiste para que a legenda seja lida. Em resposta a perguntas que não solicitam justificativas ou avaliação de hipóteses, os estudantes comunicam fragmentos do texto completando uma frase iniciada pela professora.

Sob a perspectiva da prática de construir explicações, podemos dizer que os estudantes apresentam hipótese incoerentes com o que fora lido e com o que é representado na figura, entretanto, não temos turnos em que a professora ou outros colegas indiquem inconsistências, seja pelo levantamento de uma informação relevante no texto, pela elaboração de críticas ou pela solicitação de desenvolvimento das hipóteses. Compreendemos que isso pode se dar como consequência da ausência da norma de padrões públicos que, quando vigente, orienta a construção de explicações em sala pelo esclarecimento de critérios e conhecimentos que devem dar suporte à apresentação e análise de hipóteses.

Nessa interação entre a professora e os estudantes, podemos identificar, também, a prática de obter e comunicar informações se evidenciando tanto por operações de interpretação, quanto de comunicação de informações. Inicialmente, quando a professora solicita que a turma observe as ilustrações, Maria e outro estudante não identificado acreditam que temos a representação de um barco afundando. Frente a essa interpretação equivocada, a professora solicita que os estudantes comuniquem a informação presente na legenda, o que é feito pela leitura da mesma.

Após a leitura e discussão do texto e das imagens, conforme sugerido na SEI, a professora apresenta dois problemas para que os estudantes resolvam coletivamente. 
Adaptar os problemas propostos

\begin{tabular}{|c|c|c|c|c|}
\hline \multirow{2}{*}{$\begin{array}{c}\text { Turnos } \\
\left(11^{\prime} 40{ }^{\prime \prime}-133^{\prime} 25 "\right)\end{array}$} & \multicolumn{2}{|c|}{ Evidências de Normas Culturais } & \multicolumn{2}{|c|}{ Evidências de Práticas Culturais } \\
\hline & Fórum & Igualdade Moderada & Fazer Perguntas & Construir Explicações \\
\hline $\begin{array}{l}\text { 55. Professora: [...] "Um navio mercante aportou no porto de Bilbao } \\
\text { na Espanha. Carregado de frutas do vale do São Francisco da Bahia e } \\
\text { Pernambuco. Após descarregar todas as frutas o navio não tinha carga } \\
\text { para retornar ao Brasil" ... estava vazio... descarregou as frutas e ficou } \\
\text { vazio, Fabrício... "Que medidas o capitão deverá tomar para retornar } \\
\text { com segurança ao seu porto de origem?”. ... na verdade... o que é que } \\
\text { ele já tinha que estar fazendo quando as frutas estavam sendo } \\
\text { descarregadas? }\end{array}$ & & $\begin{array}{l}\text { professora solicita } \\
\text { contribuições }\end{array}$ & $\begin{array}{l}\text { professora apresenta } \\
\text { problema } \\
\text { professora faz } \\
\text { perguntas para guiar } \\
\text { a construção de } \\
\text { explicações }\end{array}$ & $\begin{array}{c}\text { professora solicita que } \\
\text { estudantes apresentem } \\
\text { hipóteses }\end{array}$ \\
\hline 56. Estudantes: Enchendo o tanque. & $\begin{array}{c}\text { estudantes } \\
\text { apresentam } \\
\text { hipóteses } \\
\end{array}$ & $\begin{array}{c}\text { estudantes } \\
\text { apresentam } \\
\text { contribuições } \\
\end{array}$ & & $\begin{array}{l}\text { estudantes apresentam } \\
\text { hipóteses coerentes }\end{array}$ \\
\hline $\begin{array}{l}\text { 57. Professora: Enchendo o tanque de lastro...beleza... agora uma } \\
\text { outra situação "Um transatlântico aportou no porto de Santos em São } \\
\text { Paulo. Chegando da cidade de Valparaíso, no Chile. Ele chegou sem } \\
\text { passageiros e somente com a tripulação. O cruzeiro que se iniciará } \\
\text { em Santos e passará por todo o litoral sudeste do país está completo, } \\
\text { ou seja, o navio estará navegando com sua carga completa. O que o } \\
\text { capitão deverá fazer de diferente de quando chegou com o navio } \\
\text { vazio agora que o navio está completo?”... quando o navio chegou } \\
\text { vazio de carga... Diego... como é que estava o tanque de lastro? }\end{array}$ & & $\begin{array}{l}\text { professora solicita } \\
\text { contribuições }\end{array}$ & $\begin{array}{l}\text { professora apresenta } \\
\text { problema } \\
\text { professora faz } \\
\text { perguntas para guiar } \\
\text { a construção de } \\
\text { explicações }\end{array}$ & $\begin{array}{c}\text { professora solicita que } \\
\text { estudantes apresentem } \\
\text { hipóteses }\end{array}$ \\
\hline 58. Estudantes: Cheio & $\begin{array}{c}\text { estudantes } \\
\text { apresentam } \\
\text { hipóteses }\end{array}$ & $\begin{array}{c}\text { estudantes } \\
\text { apresentam } \\
\text { contribuições }\end{array}$ & & $\begin{array}{l}\text { estudantes apresentam } \\
\text { hipóteses coerentes }\end{array}$ \\
\hline $\begin{array}{l}\text { 59. Professora: Cheio... e aí as pessoas foram entrando... o que é que } \\
\text { tinha que estar acontecendo ao mesmo tempo?? }\end{array}$ & & $\begin{array}{l}\text { professora solicita } \\
\text { contribuições }\end{array}$ & $\begin{array}{c}\text { professora faz } \\
\text { perguntas para guiar } \\
\text { a construção de } \\
\text { explicações }\end{array}$ & $\begin{array}{c}\text { professora solicita que } \\
\text { estudantes apresentem } \\
\text { hipóteses }\end{array}$ \\
\hline 60. Talita: A água esvaziando & $\begin{array}{c}\text { estudantes } \\
\text { apresentam } \\
\text { hipóteses }\end{array}$ & $\begin{array}{c}\text { estudantes } \\
\text { apresentam } \\
\text { contribuições } \\
\end{array}$ & & $\begin{array}{l}\text { estudantes apresentam } \\
\text { hipóteses coerentes }\end{array}$ \\
\hline
\end{tabular}

Quadro 16: Episódio 2- Atividade 6- Mantendo embarcações na água - 29/10/2012 
Ao apresentar os problemas propostos na SEI, a professora faz pequenas alterações no enunciado e traz algumas pistas para sua resolução, como ilustrado no turno 55, quando reforça que o navio "estava vazio... descarregou as frutas e ficou vazio" e no turno 57, ao complementar a redação do problema, questionando sobre uma situação anterior "quando o navio chegou vazio de carga... Diego... como é que estava o tanque de lastro?”. Essas operações caracterizam a prática de fazer perguntas pela associação das operações de apresentar o problema e de guiar a construção de explicações, levando a turma a contrastar a situação em que o navio estava vazio, proposta no primeiro problema, e a que se constrói no segundo, conforme os passageiros embarcam.

Apresentados os problemas com suas adaptações, observamos a turma responder em coro e de forma voluntária, o que nos permite inferir que, neste momento, os estudantes são considerados e se compreendem como capazes de contribuir, ou seja, há igualdade moderada em sala. As respostas, entretanto, apesar de coerentes com o lido, não apresentam justificativas baseadas nas informações do texto (turnos 56, 58 e 60) e, como no episódio anterior, a professora aceita e repete as hipóteses sem solicitar maiores elaborações dos estudantes ou evidenciar os critérios que tornam aquelas explicações corretas, o que nos leva a concluir que as normas de padrões públicos de análise e de receptividade à crítica seguem não estabelecidas nessa aula.

Assumindo que o problema fora respondido, a professora procede com a transição para a segunda atividade a ser realizada na aula: a leitura e discussão de texto sobre "Vida marinha na água de lastro" (anexo D). Para tanto, uma vez que optou por realizar as duas atividades em uma única aula, efetua uma transição do texto anterior perguntando aos estudantes se "quando a água é colocada no tanque de lastro vocês acham que é só a ÁGUA que é colocada lá?” (turno 63). De prontidão, a turma afirma que não e passa a citar algumas espécies marinhas que poderiam ser carregas nos tanques das embarcações. Ao ouvir as hipóteses da turma, que variam de estrelas do mar e peixes a golfinhos, baleias e tubarões, a professora pondera que

"Na verdade não vai entrar animais muito grandes... coisas muito grandes... porque o espaço... não sei ao certo o tamanho da entrada da bomba... mas eu sei que não é tão grande para entrar um tubarão... vai entrar coisas menores" (turno 67). Na SEI era sugerido que essa discussão acontecesse após a leitura do segundo texto. 
Findada a transição entre as atividades, a professora realiza a leitura em voz alta do segundo texto que fora entregue impresso para os estudantes e no qual são apresentadas duas situações distintas sobre os seres vivos transportados nos tanques de lastro. Na primeira situação, esses seres vivos, seja no tanque de lastro ou no porto de destino, não encontram alimento, condições climáticas ou parceiros para reprodução e morrem; já na segunda situação, os seres vivos chegam a portos onde encontram condições ideais para sobrevivência e ausência de predadores. O texto se encerra com o seguinte problema: "Apesar de muitos indivíduos não encontrarem as condições ideais para sobreviver, há aqueles que chegam a locais que possuem boas condições climáticas, bastante alimento e sem predador. O que acontecerá com eles nessas condições?”

A partir dessa pergunta inicial, como apresentado na SEI, a professora conduz a discussão coletiva do texto, estimulando os estudantes a falar o que poderia ocorrer com um ser vivo que, porventura, tenha entrado junto com a água no tanque de lastro e, para tanto, apresenta alguns cenários para análise:

1. Considerando que, no Brasil, existe uma espécie de peixe que não existe na China. $\mathrm{O}$ que acontecerá se:

a. indivíduos dessa espécie forem transportados e sobreviverem dentro do tanque de lastro, mas ao chegarem à China não encontrarem alimento?

b. indivíduos dessa espécie forem transportados, sobreviverem dentro do tanque de lastro e ao chegarem à China encontrarem alimento, mas não encontrarem parceiros para reprodução?

Acreditamos que a apresentação da situação problema dentro de um cenário concreto pode ter sido uma maneira de a professora tentar tornar o problema mais tangível para a turma, por compreender que os estudantes estão em uma etapa de desenvolvimento cognitivo na qual, ainda que consigam desenvolver raciocínios coerentes, tendem a buscar referências em objetos ou situações passíveis de serem imaginadas de forma concreta para sustentar as ações executadas mentalmente (LA TAILLE, 1992).

As respostas a essas duas situações problemas são apresentadas em coro pela turma que repete que o peixe iria morrer. No entanto, ao apresentar uma terceira situação, a professora recebe uma hipótese incoerente com o texto que havia sido lido, como vemos no episódio que segue. 
Problematizar o texto

\begin{tabular}{|c|c|c|c|c|}
\hline \multirow{2}{*}{$\begin{array}{c}\text { Turnos } \\
\left(19{ }^{\prime} 12 "-21 ' 33 ”\right)\end{array}$} & \multicolumn{2}{|c|}{ Evidências de Normas Culturais } & \multicolumn{2}{|c|}{ Evidências de Práticas Culturais } \\
\hline & Fórum & $\begin{array}{l}\text { Igualdade } \\
\text { Moderada }\end{array}$ & Fazer Perguntas & $\begin{array}{c}\text { Construir } \\
\text { Explicações }\end{array}$ \\
\hline $\begin{array}{l}\text { 79. Professora: Ele vai morrer... e sem a fêmea lá ele não vai poder se } \\
\text { reproduzir, aí ele não vai ter mais aquele bichinho vai morrer... mas } \\
\text { também pode acontecer por exemplo de vir algum tipo animal lá da } \\
\text { China dentro do tanque de lastro aqui para o Brasil e chegar aqui... } \\
\text { encontrar alimento e vir com o macho e a fêmea... vem os dois... o } \\
\text { casalzinho.... eles vêm lá no tanque de lastro.. aí ele chega aqui no } \\
\text { Brasil no mar do Brasil e nenhum animal aqui é o predador desse } \\
\text { animal... nenhum animal gosta daquele bichinho... e o que vai } \\
\text { acontecer? hã? }\end{array}$ & & $\begin{array}{l}\text { professora solicita } \\
\text { contribuições }\end{array}$ & $\begin{array}{c}\text { professora } \\
\text { apresenta problema }\end{array}$ & $\begin{array}{l}\text { professora solicita } \\
\text { que estudantes } \\
\text { apresentem } \\
\text { hipóteses }\end{array}$ \\
\hline 80. Estudante: Vai morrer & $\begin{array}{l}\text { estudantes } \\
\text { apresentam } \\
\text { hipóteses }\end{array}$ & $\begin{array}{c}\text { estudantes } \\
\text { apresentam } \\
\text { contribuições }\end{array}$ & & $\begin{array}{l}\text { estudantes } \\
\text { apresentam } \\
\text { hipóteses } \\
\text { incoerentes }\end{array}$ \\
\hline $\begin{array}{l}\text { 81. Professora: Ele vai morrer??? presta atenção... veio o casalzinho do } \\
\text { animal... o casalzinho do bichinho veio lá da China... chegou no Brasil } \\
\text { e adoraram o local para morar porque tem tudo para eles comerem é } \\
\text { tudo de bom e... melhor ainda nenhum animal é predador dele nenhum } \\
\text { animal gosta de se alimentar dele }\end{array}$ & & & $\begin{array}{c}\text { professora } \\
\text { apresenta problema }\end{array}$ & \\
\hline \multicolumn{5}{|l|}{ 82. Estudantes: A:::: } \\
\hline 83. Professora: O que é que vai acontecer com esse casalzinho? & & $\begin{array}{l}\text { professora solicita } \\
\text { contribuições }\end{array}$ & $\begin{array}{l}\text { professora faz } \\
\text { perguntas para } \\
\text { guiar a construção } \\
\text { de explicações }\end{array}$ & $\begin{array}{l}\text { professora solicita } \\
\text { que estudantes } \\
\text { apresentem } \\
\text { hipóteses }\end{array}$ \\
\hline 84. Estudantes: Vai sobreviver & $\begin{array}{c}\text { estudantes revisam } \\
\text { hipótese }\end{array}$ & $\begin{array}{c}\text { estudantes } \\
\text { apresentam } \\
\text { contribuições }\end{array}$ & & $\begin{array}{c}\text { estudantes } \\
\text { apresentam } \\
\text { hipóteses coerentes }\end{array}$ \\
\hline
\end{tabular}

Quadro 24 - Episódio 1- Atividade 7- Leitura e discussão do texto "Vida marinha na água de lastro" - 29/10/2012 
Para cada uma das situações formuladas pela professora, como exemplificado no episódio acima, os estudantes apresentam suas hipóteses de forma espontânea, contribuindo para resolução do problema, o que nos leva a considerar que as normas de fórum e de igualdade moderada estão presentes na sala. Em uma dessas contribuições, a professora identifica uma incoerência e opta por parafrasear o problema apresentado (turno 81), o que é respondido pelos estudantes com revisão da hipótese anterior (turno 84). Não consideramos, contudo, que esses turnos evidenciam a norma de receptividade à crítica, pois a constituição dessas implica na revisão de ideias a partir da reflexão sobre uma crítica realizada e o que temos é a repetição do problema, sem a construção de uma avaliação pela professora. Uma vez que essa avaliação não é apresentada e, consequentemente, não são estabelecidos critérios e conhecimentos para ajudar os estudantes a organizar novas ideias, consideramos não haver, também, evidências da norma de padrões públicos de análise.

Observando a coluna da prática de fazer perguntas, podemos ver que, neste momento, a professora apresenta e repete algumas situações problema, mas como no momento anterior, não solicita aos estudantes que elaborem ou justifiquem suas hipóteses, conduzindo-os na construção de um argumento, mas sim que tentem interpretar o que fora lido, respondendo conforme as informações obtidas. Como consequência, a prática de construir explicações, como ocorrera na discussão do primeiro texto, não se caracteriza por operações que encorajem a turma a desenvolver e avaliar suas hipóteses ou a compará-las a fim de indicar consistências e inconsistências com as informações disponíveis.

Após esse episódio, a professora coordena uma sequência de questionamentos que ressaltam como as condições de sobrevivência favoráveis somadas à ausência de predadores conduziria a um crescimento desenfreado da espécie exótica, questão que, como ela mesma afirma para a turma, será central para as próximas atividades propostas na SEI. Esse assunto, porém, é abruptamente interrompido, possivelmente, por conta do horário de término da aula, como veremos a seguir.

5.2.4 Condução de síntese das discussões 
Sintetizar as ideias

\begin{tabular}{|c|c|c|c|c|c|}
\hline \multirow{2}{*}{$\begin{array}{c}\text { Turnos } \\
\left(230^{\prime \prime}-27{ }^{\prime} 24^{\prime \prime}\right)\end{array}$} & \multicolumn{3}{|c|}{ Evidências de Normas Culturais } & \multicolumn{2}{|c|}{ Evidências de Práticas Culturais } \\
\hline & Fórum & $\begin{array}{c}\text { Padrões Públicos } \\
\text { de Análise }\end{array}$ & $\begin{array}{l}\text { Igualdade } \\
\text { Moderada }\end{array}$ & Fazer Perguntas & Construir Explicações \\
\hline $\begin{array}{l}\text { 103. Professora: Ah... sim.. e aí esse tipo de } \\
\text { animal vai aumentando aumentando } \\
\text { aumentando e aumentando... e isso pode ser } \\
\text { um problema também... mas nós vamos } \\
\text { estudar na próxima aula... hoje o que é que a } \\
\text { gente aprendeu? principalmente }\end{array}$ & $\begin{array}{l}\text { professora repete } \\
\text { hipóteses }\end{array}$ & \multirow{9}{*}{$\begin{array}{c}\text { professora e } \\
\text { estudantes } \\
\text { retomam } \\
\text { conhecimentos já } \\
\text { estabelecidos } \\
\text { para } \\
\text { apresentação de } \\
\text { novas ideias }\end{array}$} & $\begin{array}{c}\text { professora } \\
\text { solicita } \\
\text { contribuições }\end{array}$ & $\begin{array}{l}\text { professora faz } \\
\text { perguntas para } \\
\text { retomar o que já é } \\
\text { conhecido }\end{array}$ & $\begin{array}{l}\text { professora solicita que } \\
\text { estudantes apresentem } \\
\text { explicações já } \\
\text { construídas }\end{array}$ \\
\hline $\begin{array}{l}\text { 104. Estudante: As embarcações com tanque } \\
\text { (inaudível) reproduzindo }\end{array}$ & $\begin{array}{l}\text { estudantes apresentam } \\
\text { hipóteses }\end{array}$ & & $\begin{array}{c}\text { estudantes } \\
\text { apresentam } \\
\text { contribuições }\end{array}$ & & $\begin{array}{c}\text { estudantes apresentam } \\
\text { explicações já } \\
\text { construídas }\end{array}$ \\
\hline 105. Professora: Tanque de? & $\begin{array}{l}\text { professora repete } \\
\text { hipóteses }\end{array}$ & & $\begin{array}{c}\text { professora } \\
\text { solicita } \\
\text { contribuições }\end{array}$ & $\begin{array}{c}\text { professora faz } \\
\text { perguntas para } \\
\text { retomar o que já é } \\
\text { conhecido }\end{array}$ & $\begin{array}{c}\text { professora solicita que } \\
\text { estudantes apresentem } \\
\text { explicações já } \\
\text { construídas }\end{array}$ \\
\hline 106. Estudantes: Lastro & $\begin{array}{l}\text { estudantes apresentam } \\
\text { hipóteses }\end{array}$ & & $\begin{array}{c}\text { estudantes } \\
\text { apresentam } \\
\text { contribuições }\end{array}$ & & $\begin{array}{c}\text { estudantes apresentam } \\
\text { explicações já } \\
\text { construídas }\end{array}$ \\
\hline $\begin{array}{l}\text { 107. Professora: Lastro... para que serve o } \\
\text { tanque de lastro nas embarcações? }\end{array}$ & $\begin{array}{l}\text { professora repete } \\
\text { hipóteses }\end{array}$ & & $\begin{array}{c}\text { professora } \\
\text { solicita } \\
\text { contribuições }\end{array}$ & $\begin{array}{l}\text { professora faz } \\
\text { perguntas para } \\
\text { retomar o que já é } \\
\text { conhecido }\end{array}$ & $\begin{array}{c}\text { professora solicita que } \\
\text { estudantes apresentem } \\
\text { explicações já } \\
\text { construídas }\end{array}$ \\
\hline 108. Estudantes: Para sugar e por água & $\begin{array}{l}\text { estudantes apresentam } \\
\text { hipóteses }\end{array}$ & & $\begin{array}{c}\text { estudantes } \\
\text { apresentam } \\
\text { contribuições }\end{array}$ & & $\begin{array}{c}\text { estudantes apresentam } \\
\text { explicações já } \\
\text { construídas }\end{array}$ \\
\hline $\begin{array}{l}\text { 109. Professora: E porque tem que tirar a } \\
\text { água e pôr a água? }\end{array}$ & & & $\begin{array}{c}\text { professora } \\
\text { solicita } \\
\text { contribuições }\end{array}$ & $\begin{array}{c}\text { professora faz } \\
\text { perguntas para } \\
\text { retomar o que já é } \\
\text { conhecido }\end{array}$ & $\begin{array}{l}\text { professora solicita que } \\
\text { estudantes apresentem } \\
\text { explicações já } \\
\text { construídas }\end{array}$ \\
\hline $\begin{array}{l}\text { 110. Maria: Por causa das embarcações... } \\
\text { quando uma embarcação sai a água entra. }\end{array}$ & $\begin{array}{l}\text { estudantes apresentam } \\
\text { hipóteses }\end{array}$ & & $\begin{array}{c}\text { estudantes } \\
\text { apresentam } \\
\text { contribuições }\end{array}$ & & $\begin{array}{c}\text { estudantes apresentam } \\
\text { explicações já } \\
\text { construídas }\end{array}$ \\
\hline 111. Professora: Se a embarcação sai a água & professora repete & & & & \\
\hline
\end{tabular}




\begin{tabular}{|c|c|c|c|c|}
\hline entra? & hipóteses & & & \\
\hline $\begin{array}{l}\text { 112. Estudante: E:: parabéns tá sabendo legal } \\
\text { ((um estudante aplaude e ri)) }\end{array}$ & & $\begin{array}{l}\text { estudantes } \\
\text { rejeitam } \\
\text { contribuições }\end{array}$ & & \\
\hline $\begin{array}{l}\text { 113. Professora: O que sai? Do navio para } \\
\text { entrar a água de lastro? é quando tira o quê } \\
\text { da embarcação? }\end{array}$ & & $\begin{array}{l}\text { professora } \\
\text { solicita } \\
\text { contribuições }\end{array}$ & $\begin{array}{c}\text { professora faz } \\
\text { perguntas para } \\
\text { retomar o que já é } \\
\text { conhecido }\end{array}$ & $\begin{array}{c}\text { professora solicita que } \\
\text { estudantes apresentem } \\
\text { explicações já } \\
\text { construídas }\end{array}$ \\
\hline 114. Estudantes: As cargas & $\begin{array}{l}\text { estudantes apresentam } \\
\text { hipóteses }\end{array}$ & $\begin{array}{c}\text { estudantes } \\
\text { apresentam } \\
\text { contribuições }\end{array}$ & & $\begin{array}{l}\text { estudantes apresentam } \\
\text { explicações já } \\
\text { construídas } \\
\end{array}$ \\
\hline $\begin{array}{l}\text { 115. Professora: As cargas né? Se as cargas } \\
\text { saem a água de lastro tem que entrar... e se a } \\
\text { carga entra na embarcação? }\end{array}$ & $\begin{array}{l}\text { professora repete } \\
\text { hipóteses }\end{array}$ & $\begin{array}{l}\text { professora } \\
\text { solicita } \\
\text { contribuições }\end{array}$ & $\begin{array}{c}\text { professora faz } \\
\text { perguntas para } \\
\text { retomar o que já é } \\
\text { conhecido }\end{array}$ & $\begin{array}{c}\text { professora solicita que } \\
\text { estudantes apresentem } \\
\text { explicações já } \\
\text { construídas }\end{array}$ \\
\hline 1116. Estudantes: Tira a água & $\begin{array}{l}\text { estudantes apresentam } \\
\text { hipóteses }\end{array}$ & $\begin{array}{c}\text { estudantes } \\
\text { apresentam } \\
\text { contribuições }\end{array}$ & & $\begin{array}{l}\text { estudantes apresentam } \\
\text { explicações já } \\
\text { construídas }\end{array}$ \\
\hline $\begin{array}{l}\text { 117. Professora: A água tem que sair... né? } \\
\text { certo... e quando essa água entra o que é que } \\
\text { pode entrar lá também? }\end{array}$ & $\begin{array}{l}\text { professora repete } \\
\text { hipóteses }\end{array}$ & $\begin{array}{l}\text { professora } \\
\text { solicita } \\
\text { contribuições }\end{array}$ & $\begin{array}{c}\text { professora faz } \\
\text { perguntas para } \\
\text { retomar o que já é } \\
\text { conhecido }\end{array}$ & $\begin{array}{l}\text { professora solicita que } \\
\text { estudantes apresentem } \\
\text { explicações já } \\
\text { construídas }\end{array}$ \\
\hline 118. Estudantes: Animais & $\begin{array}{l}\text { estudantes apresentam } \\
\text { hipóteses }\end{array}$ & $\begin{array}{c}\text { estudantes } \\
\text { apresentam } \\
\text { contribuições }\end{array}$ & & $\begin{array}{l}\text { estudantes apresentam } \\
\text { explicações já } \\
\text { construídas } \\
\end{array}$ \\
\hline $\begin{array}{l}\text { 119. Professora: Animais e vegetais que tem } \\
\text { lá... né? algas... que tem na vida marinha... } \\
\text { né? então por hoje é só... até a próxima }\end{array}$ & $\begin{array}{c}\text { professora repete } \\
\text { hipóteses } \\
\text { professora apresenta } \\
\text { hipótese }\end{array}$ & & & $\begin{array}{l}\text { professora apresenta } \\
\text { explicações já } \\
\text { construídas }\end{array}$ \\
\hline
\end{tabular}

Quadro 25 - Episódio 2- Atividade 7- Leitura e discussão do texto "Vida marinha na água de lastro" - 29/10/2012 
No encerramento da aula, a professora conduz um momento de sistematização do que havia sido lido, considerando as questões que os dois textos se propunham a discutir. Para tanto, retoma, juntamente com a turma, conhecimentos já estabelecidos e que serão necessários para realização das próximas atividades da SEI. Essa operação evidencia a norma de padrões públicos de análise, uma vez que tem a finalidade de esclarecer um conjunto de conhecimentos que deverá organizar e sustentar o processo de construção de explicações científicas para os problemas que serão propostos nas aulas seguintes.

Durante esse exercício de revisão, como temos a apresentação, mas não a crítica e reflexão sobre as hipóteses, podemos dizer que a norma de fórum está vigente, mas a de receptividade à crítica, segue sem se constituir. Nesse fórum, uma vez que a revisão não está em um turno único da professora, mas conta com as contribuições dos estudantes, evidenciamos a constituição de igualdade moderada., contudo, o turno 112 traz uma operação que ainda não fora vista nos episódios analisados e que caracteriza de forma peculiar essa norma. Quando Maria apresenta uma hipótese incoerente que explicita incompreensão sobre o discutido em sala, a professora não formula uma pergunta que coloque sua hipótese em teste e, em seguida, um estudante ri e rejeita a contribuição da colega. Apesar dessa situação pontual, outras contribuições não deixam de ser apresentadas.

Analisando as colunas das práticas, temos mais uma vez evidências do fazer perguntas e do construir explicações. A primeira dessas práticas se evidencia pela operação repetida pela professora de formular perguntas a fim de retomar o que já é conhecido, enquanto que a segunda prática se dá a ver pela apresentação de algumas ideias construídas durante a aula e que ajudam os estudantes a sintetizar o processo de funcionamento do tanque de lastro sem, contudo, ressaltar, a relação desse com a manutenção da flutuação das embarcações na água.

5.2.5 Considerações sobre as atividades de leitura e discussão de texto

Como feito ao final da primeira aula, trazemos a síntese das operações evidenciadas durante a realização das atividades de leitura e discussão do texto e que nos ajudarão, ao final deste trabalho, a caracterizar normas e práticas culturais que são produzidas no espaço de sala de aula de ciências organizado pelo ensino por investigação. 


\section{NORMAS CULTURAIS DO ENSINO DE CIÊNCIAS POR INVESTIGAÇÃO}

\section{Fórum}

- Estudantes apresentam/ revisam hipóteses

- Professora apresemta/ repete hipóteses

\section{Receptividade à crítica}

\section{Padrões públicos de análise}

- Professora e estudantes retomam conhecimentos já estabelecidos para apresentação de novas ideias

\section{Igualdade Moderada}

- Estudantes apresentam/ rejeitam contribuições

- Professora solicita/ rejeita contribuições

- Professora chama atenção de estudantes

\section{PRÁTICAS CULTURAIS DO ENSINO DE CIÊNCIAS POR INVESTIGAÇÃO}

\section{Fazer perguntas}

- Professora apresenta problema

- Professora faz perguntas para guiar a construção de explicações

- Professora faz perguntas para retomar o que já é conhecido

\section{Desenvolver e utilizar modelos}

\section{Planejar e executar investigações}

- Professora e estudantes identificam conhecimentos já estabelecidos pelo grupo

- Professora mapeia condições relevantes

- Professora solicita que estudantes peguem materiais

\section{Analisar e interpretar dados}

\section{Utilizar pensamento matemático e ferramentas computacionais}

\section{Construir explicações}

- Estudantes apresentam hipóteses coerentes

- Estudantes apresentam hipóteses incoerentes

- Estudantes apresentam explicações já construídas

- Professora solicita que estudantes apresentem hipóteses

- Professora solicita que estudantes apresentem explicações já construídas

- Professora apresenta explicações já construídas

\section{Engajar-se em argumentações baseadas em evidências}

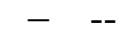




\section{Obter, avaliar e comunicar informações}

- Estudantes comunicam/ interpretam informações

- Professora lê/ destaca informações de textos

- Professora solicta que estudantes comuniquem/ interpetem informações

Quadro 26 - Síntese das normas e práticas presentes na Aula 5 - Leitura e discussão de textos

Pela análise dessa aula, encontramos evidências de três das quatro normas para construção de explicações científicas para os problemas propostos, conforme definido neste trabalho a partir das discussões de Longino (2002), e de quatro das oito práticas das comunidades científicas nas quais os estudantes de ciências devem ser iniciados (NRC, 2011), dentre as quais destacamos a presença da prática de obter, avaliar e comunicar informações que não fora contemplada na primeira atividade da SEI e a ausência da prática de utilizar pensamento matemático que fora recorrente na resolução do problema "A travessia do rio". Essa alternância de práticas, corrobora a hipótese levantada nas considerações sobre a primeira aula de que os diferentes objetivos, procedimentos de ensino e exercícios propostos ao longo da sequência possibilitariam que os estudantes vivenciassem as distintas práticas das comunidades científicas.

Iniciando a análise das operações que evidenciam a constituição das normas, podemos falar que a apresentação e revisão de hipóteses pelos estudantes e a apresentação e repetição de hipóteses pela professora indicam que a norma de fórum esteve presente ao longo da aula. Contudo, se considerarmos a baixa ocorrência de revisão de hipóteses pelos estudantes, somos levados a questionar se, de fato, durante essa aula, a sala se configurou em um espaço de apresentação, mas sobretudo, de crítica e discussão de evidências, métodos, hipóteses, argumentos, entre outros. Essa dúvida se fortalece ao considerarmos a norma de receptividade à crítica que não se evidenciou ao longo do enfrentamento e resolução do problema, uma vez que não encontramos crítica às hipóteses apresentadas que, quando reformuladas, foram alteradas em virtude da repetição do problema proposto, mas não da reflexão e revisão a partir de uma apreciação feita pela professora ou por um estudante, o que seria, conforme nossa definição, necessário para consideração de vigência da referida norma.

A falta de evidências de constituição de receptividade à crítica, a nosso ver, pode ser explicada pela ausência de uma operação da professora e dos estudantes que fora constante durante a primeira aula, mas que não aparece na aula em discussão: apresentar critérios para apresentação de hipóteses. Logo no início da aula, localizamos evidências de que a norma de padrões públicos de análise estava presente pela operação de retomar conhecimentos já estabelecidos para apresentação de novas ideias, o que se repete ao final da atividade, no 
momento de síntese das discussões como encaminhamento para aula seguinte. Entretanto, essa norma não se evidencia ao longo do enfrentamento e resolução dos problemas, ou seja, não há o estabelecimento e reconhecimento coletivo de critérios e conhecimento que deverão dar suporte à proposição e à análise de novas ideias e, consequentemente, pela ausência de critério, não há avaliação ou revisão de hipóteses a partir desses, não se estabelecendo a norma de receptividade à crítica.

Encerrando nossas considerações sobre as normas, ao focarmos as operações que evidenciam a constituição de igualdade moderada, pela constante presença de solicitações e apresentações de contribuições, compreendemos que existe em sala um ambiente onde a participação de todos é estimulada e reconhecida. Destacamos, apenas, que as duas leituras realizadas pela professora são entrecortadas por advertências e pedidos de silêncio, indicando, como na aula anterior, que existem situações como a apresentação do problema ou a comunicação de informações importantes para seu enfrentamento, nas quais a igualdade em sala é moderada pela autoridade da professora que busca um controle sobre a turma, a fim de que todos acompanhem o que está sendo apresentado.

Passando para a discussão das práticas culturais, iniciemos observando as operações que são encontradas na aula analisada em virtude de essa estar articulada a outras atividades da sequência já realizadas por aquela sala. Com relação à prática de fazer perguntas, vemos um esforço da professora de retomar o que já é conhecido por meio de questionamentos que ajudem os estudantes a se lembrar de algumas atividades e das ideias centrais construídas a partir dessas. Esse mesmo tipo de operação aparece ao final da aula na formulação de perguntas que conduzem a construção de uma síntese do que fora lido e debatido, criando condições para introdução, ainda que bastante breve, do próximo tópico de conteúdo a ser abordado.

Essa articulação entre as atividades da SEI se reflete, também, na prática de construir explicações evidenciada por operações como a solicitação de que explicações já construídas sejam retomadas e a exposição dessas explicações pela professora e pelos estudantes como meio de rememorar, mas também, de oferecer pistas para professora de que a turma está acompanhando as discussões. Já na prática de planejar e executar investigações, temos a identificação de conhecimentos já estabelecidos pelo grupo como operação que precede a realização da investigação que será proposta na aula e que, como visto nas comunidades científicas, é uma etapa importante para a definição do desenho de pesquisa, para a construção de embasamento teórico e para a análise e revisão de proposições durante uma investigação. 
Ainda trazendo nossas considerações sobre a prática de planejar e executar investigações, temos outra operação que não aparecera, anteriormente, em decorrência das diferentes propostas de trabalho presentes ao longo da SEI. Para leitura e discussão dos textos, os estudantes receberam material impresso e, como parte do planejamento do modo de trabalho, a professora indica aos estudantes os momentos em que cada um desses materiais deveria ser utilizado, solicitando, por exemplo, que acompanhem o texto, ou observem a ilustração. Como outra operação que evidencia essa prática, o mapeamento de condições relevantes para resolução dos problemas ocorre durante os dois momentos de leitura de texto por meio de gestos, entonações ou comentários da professora que aponta as informações que serão centrais para compreensão e enfrentamento das situações propostas na SEI.

Retomando a prática de fazer perguntas, durante a leitura dos problemas pela professora, temos a junção das operações de apresentar o problema e de fazer perguntas que guiem a construção de explicações, o que parece-nos ser uma maneira de ajudar a turma a comparar os problemas propostos e a organizá-los em etapas menores a serem respondidas. Durante o enfrentamento e resolução dos problemas, a operação de fazer perguntas para guiar a construção de explicações, quando analisada em conjunto com a prática de construir explicações, parece afastar-se da dimensão epistêmica característica de abordagens investigativas para o ensino de ciências, uma vez que operações como a solicitação e apresentação de avaliações ou justificativas não estão presentes na aula.

Nesse mesmo sentido, entre as operações que evidenciam a prática de construir explicações, temos a apresentação de hipótese coerentes e incoerentes, entretanto, o apontamento das inconsistências dessas não ocorre, seja em turnos da professora, seja em turnos dos estudantes, o que acreditamos poder ser explicado pela ausência ou fragilidade de algumas das normas culturais para construção de explicações científicas para os problemas propostos. Essas normas, como dito por Longino (2002). garantem a construção de interações discursivas críticas, entretanto, uma vez que não se estabelece a necessidade de crítica e revisão de ideias e que os padrões públicos não são partilhados pelo grupo, deixa-se de criar oportunidades para que a sala avalie as explicações apresentadas ou compare diferentes hipóteses indicando consistências e inconsistências com as informações disponíveis. Como possível consequência disso, as explicações coletivas são expressas de forma bastante concisa, sem justificativas ou articulação de ideias o que analisamos como evidência de que práticas epistêmicas não foram vivenciadas nessa aula.

Ao discutir sobre as relações entre as práticas epistêmicas e as práticas científicas no ensino de ciências, Jiménez-Aleixandre e Crujeiras (2017) afirmam que nem todas as práticas 
científicas apresentam caráter epistêmico. Nessa perspectiva, seguem as autoras, existem práticas como o processo de pensamento avaliativo que podem ser classificadas como epistêmicas, nas não são exclusivas das práticas científicas, assim como existem práticas como a mensuração que podem ser classificadas como científicas, mesmo quando não possuam caráter epistêmico. Em contextos como o de avaliação de uma hipótese ou de desenvolvimento de explicações, esses dois conjuntos de práticas podem se sobrepor e, por exemplo, os instrumentos e critérios de mensuração serem planejados e realizados já com um propósito específico, como gerar dados a fim de comparar e avaliar os impactos de determinada substância no ambiente.

$\mathrm{Na}$ análise das primeira e da quinta aula, vemos exemplos dessas duas situações distintas apontadas por Jiménez-Aleixandre e Crujeiras (2017). Como exemplo de sobreposição de práticas epistêmicas e científicas, na atividade da "Travessia do rio", o fazer perguntas, tanto como prática da professora quanto dos estudantes, cumpre a finalidade de guiar a construção de justificativas, de testar hipóteses, de articular explicações e de estabelecer critérios para decidir o que será considerado como resposta para o problema. Ou seja, à medida em que as perguntas são formuladas, em resposta, algumas hipóteses são comunicadas, comparadas, avaliadas em suas inconsistências, reformuladas e justificadas em um movimento que conduz à formulação de uma explicação para o problema e à explicitação dos porquês de essa ser considerada correta. Esse processo vivido em sala se assemelha à construção de conhecimento pelas comunidades científicas por meio de práticas epistêmicas de proposição, comunicação, avaliação e legitimação (KELLY; LICONA, 2018).

Em outros momentos de implementação da SEI, como ilustrado na quinta aula, as práticas científicas e epistêmicas se afastam e, ainda que tenhamos, por exemplo, a prática de construir explicações, observamos que, pela ausência de apreciação e avaliação das respostas dadas, as ideias apresentadas em aula mais se assemelham à repetição de informações do que à organização justificada de hipóteses ou ao estabelecimento de relações a fím de entender os fenômenos estudados. Como consequência, as explicações, são muito mais descritivas do que explicativas dos fenômenos, o que interpretamos como um indício de que as práticas científicas encontradas são revestidas de um caráter mais disciplinar que epistêmico. Para ilustrar esse afastamento entre as práticas epistêmicas e científicas, trazemos a explicação construída ao final da quinta aula, na qual podemos perceber que as relações entre o tanque de lastro e a manutenção de estabilidade das embarcações na água não é estabelecida e a sala, apenas, descreve a situação sem questionar por que esse mecanismo funciona. 
Professora: Para que serve o tanque de lastro nas embarcações? $\rightarrow$ Estudantes: Para sugar e por água $\rightarrow$ Professora: E porque tem que tirar a água e pôr a água? $\rightarrow$ Estudantes e professora: (por causa das) cargas née Se as cargas saem a água de lastro tem que entrar $\rightarrow$ Professora: E se a carga entra na embarcação? $\rightarrow$ Estudantes: Tira a água

Figura 8 - Explicações construídas durante a resolução dos problemas propostos na Aula 5 - Leitura e discussão de textos

Retomando nossas considerações sobrea o quadro 26, acreditamos poder afirmar que nessa aula a prática de obter, avaliar e comunicar informações surge em decorrência do perfil da atividade que consiste no uso de textos e ilustrações como fonte de informações para resolução de problemas. Na implementação da atividade, a leitura dos textos foi realizada pela professora que leu e destacou informações por meios de paráfrases, gestos e tonalidade de voz. Nos turnos dos estudantes, essa prática se evidenciou na interpretação e, principalmente, comunicação de informações dos textos e das ilustrações e suas legendas. Entretanto, questionamos se essa prática foi plenamente estabelecida na aula, uma vez que a comunicação de informações foi, com frequência, realizada com bastante dificuldade pela turma, como podemos ver durante a leitura das legendas (turnos 40 a 45), na confusão sobre a possibilidade de sobrevivência do casal de animais marinhos carregados no tanque de lastro (turno 77 a 84) ou mesmo no momento de síntese da aula, quando entre os turnos 109 e 113, é possível interpretar que, pelo menos para alguns estudantes, as informações apresentadas não estão claras.

Concluídas nossas considerações sobre as normas e práticas presentes nessa aula, trazemos alguns elementos para pensar sobre a possibilidade de considerarmos se, durante a realização das atividades propostas, a sala se constituiu como uma comunidade de práticas e, para tanto, buscamos as três características que, conforme nosso referencial teórico (LAVE; WENGER, 1991; WENGER; SNYDER, 2001; WENGER, 2016), são necessárias para o estabelecimento dessas comunidades: existência de um engajamento mútuo, a identificação com um mesmo empreendimento e a partilha de um repertório.

Para constituição de uma comunidade de prática é imprescindível que seja garantida a livre interação entre os membros, ainda que respeitadas as relações hierárquicas, de modo que todos possam participar. Essa necessidade de engajamento mútuo, como explica Wenger (2016), não pressupõe consenso de ideias, ou ainda harmonia, sendo possível que o trabalho seja realizado de forma colaborativa ou marcado pela concorrência. Tendo isso em vista, 
acreditamos que existe engajamento mútuo em sala, uma vez que, mesmo que marcada por relações de poder, a participação de grande parte da turma é frequente e espontânea.

Como segunda característica da comunidade de práticas, temos a necessidade de partilha de um repertório que é composto, entre outros, por ferramentas e signos já utilizados e que se mantêm disponíveis para novas realizações, o que aparece de forma pontual, por exemplo, no momento em que a professora retoma o conceito de predador com a turma (turno 71 a 75) recuperando um signo construído em outras aulas e que parece se manter disponível para o grupo. Esse repertório, segundo Wenger (2016), é criado ao longo do tempo, conforme os membros da comunidade se engajam em diferentes projetos, o que se revela, por exemplo, pelo uso da lousa que se constitui na escola como recurso de registro e partilha e que, como na aula anterior, é utilizado pela professora como ferramenta para destacar ideias, como o conceito de lastro (turno 33). No entanto, se considerarmos o repertório material (texto e ilustrações impressos) oferecido durante a atividade e pensarmos que o repertório de uma comunidade deve ser produzido e/ou adotado durante a realização de seus projetos, sendo partilhados por seus membros, questionamos a possibilidade de afirmar que essa característica está presente na aula.

No registro em vídeo, é possível observar que grande parte dos estudantes, apesar de ter recebido o texto impresso, não acompanha a leitura nesse material, deixando-o sobre a mesa enquanto olha para professora, ou mesmo, utilizando o papel para se abanar ou para bater em algum colega. Já durante a leitura das imagens, dos catorze estudantes que são filmados initerruptamente, apenas Maria observa a ficha que recebeu e, ainda assim, interpreta a ilustração de forma equivocada o que nos remete à afirmação de Certeau (1985) de que para conhecer as práticas culturais de um grupo, é preciso analisar não somente seu repertório, mas seus procedimentos de consumo, isto é, as maneiras como esse foi empregado. Dessa forma, ainda que bens (material impresso) que compõem o repertório do Ensino de Ciências por Investigação estivessem disponibilizados para a sala, seus usos parecem indicar que esse não fora, plenamente, partilhado.

A terceira característica a ser localizada para definição de um grupo como uma comunidade de práticas é a identificação com um projeto, construída durante um processo de negociação do problema recebido no qual deve existir protagonismo dos envolvidos de modo que as atividades realizadas nunca sejam, totalmente, determinadas por agentes ou fatores externos. No entanto, na aula analisa, esse processo de negociação parece ter sido prejudicado no momento em que a professora optou por centralizar a leitura e interpretação dos problemas ao invés de, como sugerido na SEI, aproveitar o momento de leitura para incentivar os 
estudantes a destacar o que acharam mais importante no texto o que acreditamos ter diminuído as possibilidades de, juntamente com a turma, mapear o que era mais relevante no texto, entender os problemas e, assim, criar identificação com a atividade a ser realizada. Outro indício de que essa característica não está presente são os turnos em que a professora precisa chamar atenção de algum estudante (turnos 27, 29, 31, 33, 53, 55, 57, 63, 71 e 77) ou de toda turma (turno 1), demonstrando que as normas de participação não estão claras ou não são respeitadas; bem como as situações em que Fabrício provoca Diego dizendo que a advertência que o colega recebeu da professora ficaria gravada no vídeo (turno 30) ou em que um estudante ri do erro de Maria (turno 112) o que, mesmo sendo eventos esporádicos, pode indicar que não se estabeleceu uma relação de respeito e confiança no grupo. Tanto a vigência de normas de participação, quanto o estabelecimento de respeito e confiança são centrais para a constituição de uma comunidade de práticas (WENGER; SNYDER, 2001).

Concluindo essas considerações parciais, parece-nos coerente dizer que, ainda que não saibamos as razões de os critérios para apresentação de novas ideias não terem sido estabelecidos com o grupo (padrões públicos de análise) e de, consequentemente, a norma cultural de receptividade à crítica não ter se constituído durante a realização dessas atividades, a análise da presente aula nos traz indicações de que ao enfraquecimento dessas normas resultou em uma diminuição de operações mais relacionadas às dimensões social e epistêmica do ensino de ciências o que se refletiu nas maneiras como as práticas culturais foram vivenciadas nessa aula e parece ter impossibilitado a caracterização da sala como uma comunidade de práticas.

\subsection{Aula 8 - Análise dos dados da tabela}

A última atividade escolhida para análise aconteceu na oitava aula de implementação da SEI, realizada em 11 de novembro de 2012 (cerca de 45 minutos registrados em vídeo). A atividade que orienta a presente aula, "Análise dos dados da tabela" (atividade 9), relaciona-se a um jogo de pega-pega chamado "Presa e predador" (atividade 8) que, como apresentado na seção 3.1.1 deste trabalho, teve o objetivo de levar os estudantes a pensar sobre cadeia alimentar e sobre os impactos advindos do crescimento ou da diminuição da população de uma das espécies que a constitui. A nona atividade é apresentada à professora como segue no mapa abaixo. 


\begin{tabular}{|c|c|c|}
\hline Objetivos explicitados & Procedimentos de ensino & Exercícios \\
\hline $\begin{array}{l}\text { Ajudar os estudantes a } \\
\text { reconstruir o jogo "presa e } \\
\text { predador" mentalmente, } \\
\text { tomando consciência do que } \\
\text { ocorreu ao longo da } \\
\text { brincadeira, associando-a à } \\
\text { dinâmica das populações } \\
\text { Conduzir os estudantes na } \\
\text { leitura da tabela associando } \\
\text { informações contidas em } \\
\text { linhas e colunas } \\
\text { Levar a turma a construir } \\
\text { explicações causais para o } \\
\text { fenômeno das populações } \\
\text { estudado com os dados do } \\
\text { jogo }\end{array}$ & $\begin{array}{l}\text { Conforme, as rodadas do } \\
\text { jogo "presa e predador", } \\
\text { registrar a situação da } \\
\text { população de cada ser vivo } \\
\text { em uma tabela na lousa } \\
\text { Organizar a turma em trios } \\
\text { para discussão de oito } \\
\text { questões a partir das } \\
\text { informações da tabela } \\
\text { Conduzir a partilha das } \\
\text { resoluções encontradas pelos } \\
\text { diferentes grupos, } \\
\text { sustentados pela leitura da } \\
\text { tabela } \\
\text { Para síntese da atividade, } \\
\text { realizar a leitura do texto } \\
\text { "Entendendo o jogo 'presa e } \\
\text { predador" }\end{array}$ & $\begin{array}{l}\text { Os estudantes devem } \\
\text { reproduzir no caderno a } \\
\text { tabela feita na lousa pela } \\
\text { professora } \\
\text { Feito isso, em trios, os } \\
\text { estudantes devem resolver } \\
\text { oito questões a partir das } \\
\text { informações da tabela } \\
\text { Após resolver as questões, } \\
\text { cada grupo deve partilhar } \\
\text { com a professora e demais } \\
\text { colegas de sala quais } \\
\text { possibilidades de resolução } \\
\text { foram encontradas } \\
\text { Acompanhar a leitura a do } \\
\text { texto "Entendendo o jogo } \\
\text { 'presa e predador" } \\
\text { Ao final da discussão, cada } \\
\text { estudante deve escrever e/ou } \\
\text { desenhar as conclusões da } \\
\text { turma sobre o jogo "presa e } \\
\text { predador" }\end{array}$ \\
\hline
\end{tabular}

Quadro 27 - Mapa da atividade 9 "Análise dos dados da tabela"

Pela análise do mapa de atividade, identificamos algumas orientações que nos remetem às dimensões que devem compor os objetivos para o ensino de ciências como prática (STROUPE, 2015), tais como adotadas para este trabalho. Nessas orientações, ressaltamos a presença da dimensão material que, quando comparada às atividades anteriores, aparece com maior destaque no planejamento dos objetivos, procedimentos e exercícios, uma vez que a presente atividade traz diretrizes específicas que se relacionam ao uso de ferramentas para análise e interpretação de dados no processo de construção, comunicação e apreciação de explicações científicas para os problemas propostos. De modo mais específico, a leitura de tabela guiada por questionamentos que pretendem levar os estudantes a construir explicações causais para o fenômeno das populações estudado a partir dos dados do jogo. Essa dimensão pode ser promovida, também, pelo registro final que deve ser feito pelos estudantes e pelas anotações, cálculos e outros recursos utilizados durante o enfrentamento dos problemas. 
Ainda pelo observado no mapa, identificamos a possibilidade de trabalho com a dimensão social na diretriz de que os problemas sejam enfrentados coletivamente, sendo indicados dois momentos que podem permitir aos estudantes negociarem hipóteses e, em seguida, partilhá-las com a turma, conforme regras de participação sugeridas na SEI ou vigentes em sala. Durante esse processo, é possível, também, que a dimensão epistêmica seja trabalhada à medida em que essas explicações sejam comunicadas, avaliadas e revisadas pelos estudantes durante o trabalho em grupos ou ao longo da partilha das resoluções encontradas.

Considerando a dimensão conceitual, não temos explicitado um princípio, teoria, lei ou outros conteúdos que os estudantes precisam dominar ao final da aula, contudo, é sugerido que os estudantes construam explicações causais relacionadas ao jogo e que serão ampliadas na atividade seguinte (atividade 10 - leitura e discussão do texto "As populações crescem e diminuem"), na qual os estudantes poderão refletir sobre o equilíbrio entre as espécies envolvidas no jogo e ampliar essa discussão para outras populações de presa e de predadores, bem como se familiarizar com um vocabulário específico. Essa dimensão pode ser vivenciada, também, pela realização de cálculos, comparações de valores e outras operações que exigem o uso de repertório da matemática durante a análise e interpretação dos dados da tabela.

A implementação dessa proposta acontece na sala de aula regular do $3^{\circ}$ ano. Representamos esse espaço, conforme pode ser visto no vídeo, identificando os conjuntos de mesas pelos retângulos maiores, as cadeiras pelos retângulos menores pretos e os pontos da sala que não são capturados ao longo da filmagem pelas áreas acinzentadas.

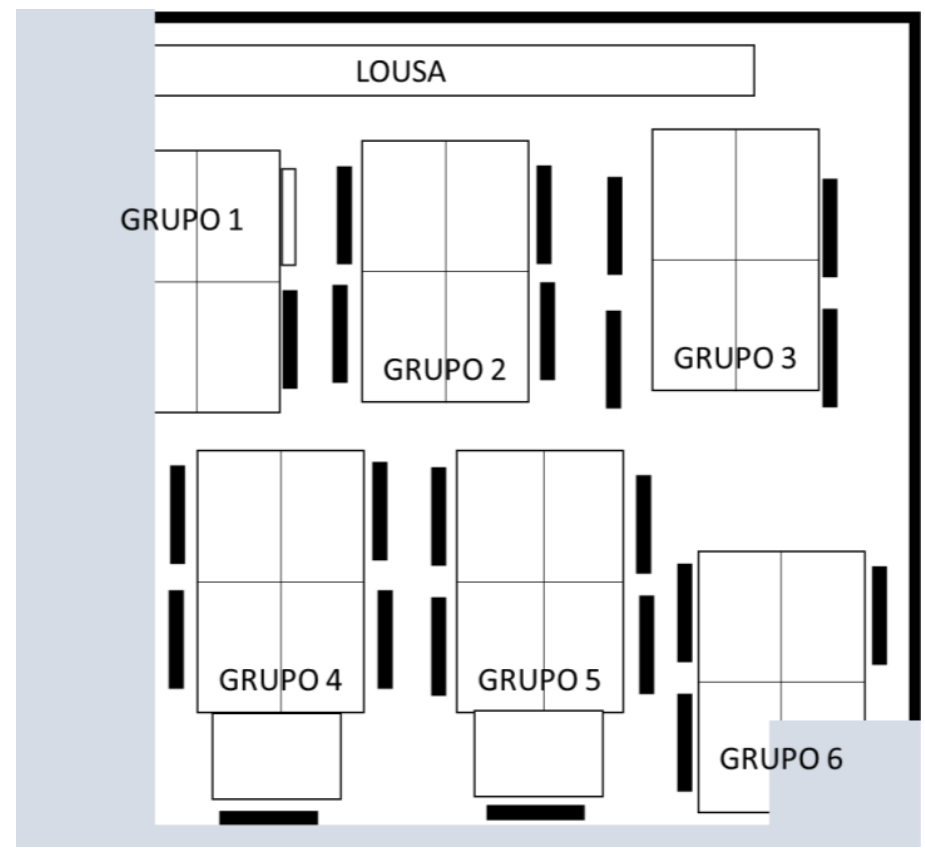


Figura 9 - Representação gráfica da sala, conforme registro em vídeo, durante Aula 8 - Análise dos dados da tabela

No decorrer da aula, a professora circula pelos corredores formados pelos grupos e auxilia os estudantes que estão com seus estojos e as fichas sobre a mesa. Já durante a partilha das hipóteses levantadas pelos grupos, a professora se mantém próxima à parte central da lousa.

A gravação da aula tem início quando os estudantes já estão agrupados e preenchem uma ficha com algumas informações registradas em lousa pela professora, como pode ser visto na figura 10. Na ficha recebida pelos estudantes, está impressa uma tabela com células vazias para anotação dos dados encontrados durante a brincadeira (anexo E).

ENQUANTO BRINCAMOS DE PRESA E PREDADOR, A PROFESSORA REGISTROU AS SITUAÇÕES PARA CADA GRUPO DE SERES VIVOS EM CADA UMA DAS RODADAS EM UMA TABELA COMO ESTA, ONDE PODEMOS VER A QUANTIDADE DE PLANTAS, TAPITIS E JAGUATIRICAS DE CADA RODADA.

\begin{tabular}{|c|c|c|c|}
\hline RODADA & PLANTA & TAPITI & JAGUATIRICA \\
\hline $1^{\mathrm{a}}$ & 9 & 7 & 7 \\
\hline $2^{\mathrm{a}}$ & 8 & 11 & 4 \\
\hline $3^{\mathrm{a}}$ & 4 & 16 & 3 \\
\hline $4^{\mathrm{a}}$ & 11 & 7 & 5 \\
\hline $5^{\mathrm{a}}$ & 11 & 9 & 3 \\
\hline $6^{\mathrm{a}}$ & 6 & 11 & 6 \\
\hline $7^{\mathrm{a}}$ & 1 & 7 & 15 \\
\hline
\end{tabular}

Figura 10 -Informações presentes na lousa durante a Aula 8 - Análise dos dados da tabela

Conforme os procedimentos de ensino propostos na SEI, a professora conduz a aula em cinco momentos, como ilustrado a seguir. 


\section{A APRESENTAÇÃO DO PROBLEMA}

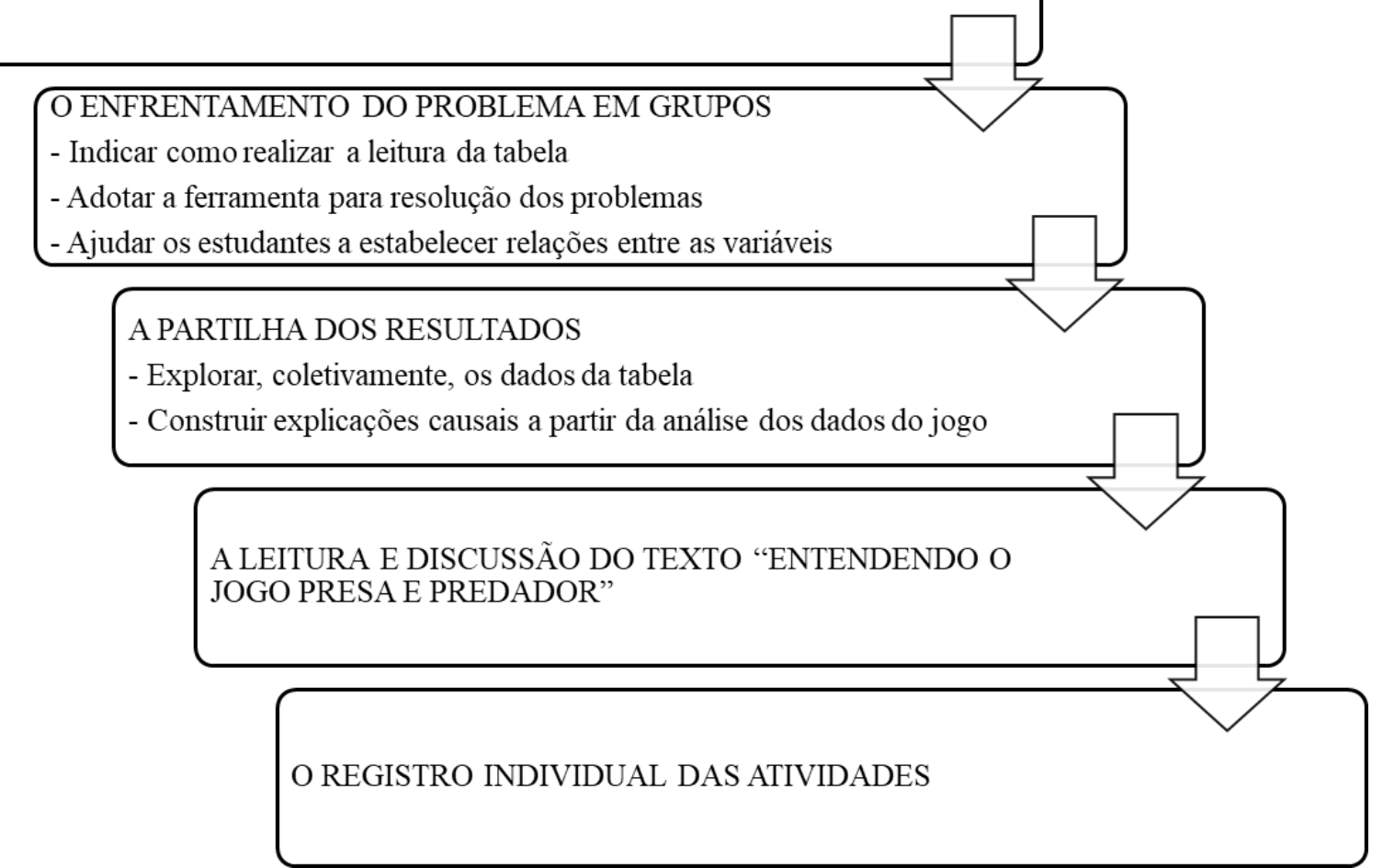

Figura 11 - Momentos e episódios da Aula 8 - Análise dos dados da tabela

\subsubsection{A apresentação do problema}

A aula inicia com uma breve retomada conduzida pela professora do jogo realizado no dia anterior. Em seguida, observamos a apresentação dos passos para realização da atividade, conforme proposto na SEI, e a entrega de uma segunda ficha para os estudantes, contendo oito questões (anexo F) a serem respondidas pelos grupos.

Neste primeiro momento, ainda não temos a proposição de um problema, mas a professora já antecipa o plano de trabalho que será adotado ao longo da aula, como apresentamos a seguir:

Turno 7: Professora: sete né? aí vocês preencheram a tabela... agora... eu vou entregar umas questões pra vocês... tá dizendo assim... agora... com SEUS COLEGAS discuta e responda as questões ABAIXO e depois ESCREVA e DESENHE sobre suas conclusões... né Fábio? o que é que vocês descobriram... né... que conclusão... o que que vocês descobriram... o que acontece naquele jogo... e desenhar também... tá bom? O desenho pode ser no caderno. 
Como este plano sugere a realização do trabalho de maneira colaborativa, acreditamos que existe a possibilidade de, inicialmente, os pequenos grupos e, posteriormente, a sala toda, configurarem-se como espaços de apresentação, crítica e revisão de métodos para análise e interpretação dos dados, bem como de hipóteses que levem à resolução dos problemas propostos. Com isso, identificamos aqui uma evidência de que a norma de fórum pode se constituir ao longo dessa aula.

Sob a perspectiva das práticas, já neste momento inicial, destacamos o analisar $e$ interpretar dados que, como visto no planejamento da atividade, ocupa papel central nessa aula. Encontramos evidências dessa prática quando a professora, ao ler e explicar o texto presente na ficha recebida pelos estudantes, destaca como os dados estão organizados na tabela, indicando para os estudantes que essa ferramenta possibilita "ver a quantidade de plantas... tapitis... jaguatiricas de cada rodada" (turno 3). Ao fazer isso, a professora oferece indicações aos estudantes de como realizar a análise dos dados e, com isso, cria mais possibilidades para que eles compreendam os usos da tabela e para que adotem essa ferramenta.

Após a apresentação da atividade, a professora começa a caminhar por entre as mesas distribuindo a ficha com as questões a serem respondias e trocando alguns estudantes de lugar para que os grupos fiquem com uma quantia de integrantes mais equilibrada. Enquanto reorganiza os grupos, esclarece as normas que regem a participação naquele momento e informa para turma que "mesmo quem não veio... vai poder responder porque tem a tabela aí... tem todos os dados... e as perguntas é pra analisar a tabela... então... mesmo quem faltou... vai conseguir analisar" (turno 9). Apesar desse esclarecimento, quando a professora se aproxima do grupo 6, escuta de um dos estudantes que alguns de seus colegas faltaram à aula anterior, quando o jogo fora realizado. Em resposta, explica, em tom de voz elevado para que toda sala possa ouvir que, como os dados coletados durante o pega-pega foram registrados na tabela, todos poderão ver o que aconteceu e, em seguida, instrui o grupo 6, reafirmando que é possível localizar os dados na tabela, independentemente da participação no jogo, como ilustramos com o turno 16

Professora: Você veio? mas aí... É SÓ LER AS PERGUNTAS E ANALISAR A TABELA... PRIMEIRO QUEM NÃO VEIO... VAI PODER... VÊ AÍ O QUE ACONTECEU... ENTENDEU? a Ana não veio... mas ela também estava... ela já lê a pergunta e vocês procuram na tabela o que foi que aconteceu... cadê a sua tabela?

Ao fazer isso, a professora apresenta como o repertório disponibilizado para aula permite a prática de analisar e interpretar dados coletados em situações anteriores, ou mesmo 
por outras pessoas. Esse repertório foi construído, pois, a partir do planejado na SEI, foram criadas condições para que o objeto de estudo (o jogo presa e predador) fosse materializado em uma inscrição literária (tabela) que serviria de matéria-prima para elaboração dos enunciados científicos (explicações causais sobre a dinâmica das populações dentro de uma cadeia alimentar), similarmente ao que é feito nas comunidades científicas (LATOUR; WOOLGAR, 1997).

\subsubsection{O enfrentamento do problema em grupos}

O enfrentamento do problema pelos grupos ocupa cerca de dezesSEI minutos da aula, durante os quais a professora buscou ajudar os estudantes com a leitura dos dados e com a interpretação desses a fim de construir explicações para cada um dos problemas propostos. Neste segundo momento, muitas das discussões são inaudíveis, mas à medida em que a professora se aproxima dos grupos, é possível ouvir os diálogos entre os estudantes e entre eles e a professora. Essas interações são exemplificadas nos três episódios a seguir. 
Indicar como realizar a leitura da tabela

\begin{tabular}{|c|c|c|c|c|c|c|c|c|}
\hline \multirow[b]{2}{*}{$\begin{array}{c}\text { Turnos } \\
\left(6{ }^{\prime} 21^{\prime \prime}-9^{\prime} 14^{\prime \prime}\right)\end{array}$} & \multicolumn{3}{|c|}{ Evidências de Normas Culturais } & \multicolumn{5}{|c|}{ Evidências de Práticas Culturais } \\
\hline & Fórum & $\begin{array}{l}\text { Padrões } \\
\text { Públicos de } \\
\text { Análise }\end{array}$ & $\begin{array}{l}\text { Igualdade } \\
\text { moderada }\end{array}$ & $\begin{array}{c}\text { Fazer } \\
\text { Perguntas }\end{array}$ & $\begin{array}{c}\text { Planejar e } \\
\text { Executar } \\
\text { Investigações }\end{array}$ & $\begin{array}{l}\text { Analisar e } \\
\text { Interpretar } \\
\text { Dados }\end{array}$ & \begin{tabular}{|c|} 
Utilizar \\
pensamento \\
matemático e \\
ferramentas \\
computacionais \\
\end{tabular} & $\begin{array}{l}\text { Construir } \\
\text { Explicações }\end{array}$ \\
\hline $\begin{array}{l}\text { 21. Professora: Lê em voz } \\
\text { alta... aí todo mundo ouve... e } \\
\text { vai procurando... Ariel... a } \\
\text { primeira rodada é aqui o:.: e a } \\
\text { segunda rodada é aqui... não é } \\
\text { de assim que cê vai olhar... é } \\
\text { de assim ((professora faz um } \\
\text { movimento com a mão } \\
\text { indicando que o estudante } \\
\text { deve olhar as linhas e não as } \\
\text { colunas da tabela)) }\end{array}$ & $\begin{array}{l}\text { professora } \\
\text { apresenta } \\
\text { métodos de } \\
\text { investigação }\end{array}$ & $\begin{array}{l}\text { professora } \\
\text { apresenta } \\
\text { critérios para } \\
\text { análise de } \\
\text { hipóteses }\end{array}$ & & & \begin{tabular}{c|} 
professora \\
apresenta \\
métodos de \\
investigação
\end{tabular} & $\begin{array}{l}\text { professora } \\
\text { indica como } \\
\text { analisar } \\
\text { dados }\end{array}$ & $\begin{array}{c}\text { professora } \\
\text { indica como } \\
\text { utilizar } \\
\text { pensamento } \\
\text { matemático }\end{array}$ & \\
\hline $\begin{array}{l}\text { 22. Manoel: ((Manoel } \\
\text { conversa com um colega a seu } \\
\text { lado)) Eu sei a primeira } \\
\text { (inaudível) }\end{array}$ & & & & & & & & \\
\hline $\begin{array}{l}\text { 24. Professora: Isso! pega a } \\
\text { tabela... “que rodada... o } \\
\text { número de plantas foi maior?" } \\
\text { então... tem que escrever isso } \\
\text { aí... Ariel... olha lá na... na } \\
\text { tabela... em qual rodada o } \\
\text { número de plantas foi maior? }\end{array}$ & $\begin{array}{l}\text { professora } \\
\text { apresenta } \\
\text { planos de } \\
\text { trabalho }\end{array}$ & & $\begin{array}{c}\text { professora } \\
\text { solicita } \\
\text { contribuições }\end{array}$ & $\begin{array}{l}\text { professora } \\
\text { apresenta } \\
\text { problema }\end{array}$ & $\begin{array}{l}\text { professora } \\
\text { solicita que } \\
\text { estudantes } \\
\text { peguem } \\
\text { materiais }\end{array}$ & & $\begin{array}{l}\text { professora } \\
\text { solicita que } \\
\text { estudantes } \\
\text { apresentem } \\
\text { hipóteses } \\
\text { utilizando } \\
\text { pensamento } \\
\end{array}$ & $\begin{array}{l}\text { professora } \\
\text { solicita que } \\
\text { estudantes } \\
\text { apresentem } \\
\text { hipóteses }\end{array}$ \\
\hline
\end{tabular}




\begin{tabular}{|c|c|c|c|c|c|c|c|c|}
\hline & & & & & & & matemático & \\
\hline $\begin{array}{l}\text { 25. Ariel: Aqui? ((Ariel } \\
\text { aponta para sua folha)) }\end{array}$ & $\begin{array}{l}\text { estudantes } \\
\text { apresentam } \\
\text { hipóteses }\end{array}$ & & $\begin{array}{c}\text { estudantes } \\
\text { apresentam } \\
\text { contribuições }\end{array}$ & $\begin{array}{l}\text { estudante faz } \\
\text { perguntas } \\
\text { para testar } \\
\text { hipóteses }\end{array}$ & & $\begin{array}{c}\text { estudantes } \\
\text { analisam } \\
\text { dados }\end{array}$ & $\begin{array}{c}\text { estudantes } \\
\text { apresentam } \\
\text { hipóteses } \\
\text { utilizando } \\
\text { pensamento } \\
\text { matemático }\end{array}$ & $\begin{array}{l}\text { estudantes } \\
\text { apresentam } \\
\text { hipóteses } \\
\text { incoerentes }\end{array}$ \\
\hline $\begin{array}{l}\text { 26. Professora: Não... olha de } \\
\text { novo... "em qual rodada... o } \\
\text { número de plantas foi maior?" } \\
\text { aqui foi a primeira rodada... } \\
\text { segunda... terceira... quarta... } \\
\text { quinta... sexta e sétima } \\
\text { ((professora aponta para as } \\
\text { linhas da tabela)) em qual } \\
\text { rodada... teve mais plantas? } \\
\text { não é pra escrever... olha } \\
\text { aqui... planta... não precisa } \\
\text { anotar aqui... espera... é pra } \\
\text { analisar... tá perguntando em } \\
\text { qual rodada... aqui é planta... } \\
\text { aqui é o tapiti e aqui é a } \\
\text { jaguatirica... aí... você vai } \\
\text { olhar assim... quem foram os } \\
\text { seres vivos da da brincadeira... } \\
\text { mas a rodada é vertical }\end{array}$ & $\begin{array}{l}\text { professora } \\
\text { apresenta } \\
\text { críticas } \\
\text { professora } \\
\text { apresenta } \\
\text { métodos de } \\
\text { investigação }\end{array}$ & $\begin{array}{c}\text { professora } \\
\text { apresenta } \\
\text { critérios para } \\
\text { análise de } \\
\text { hipóteses }\end{array}$ & $\begin{array}{c}\text { professora } \\
\text { rejeita } \\
\text { contribuições } \\
\text { professora } \\
\text { solicita } \\
\text { contribuições }\end{array}$ & $\begin{array}{l}\text { professora } \\
\text { apresenta } \\
\text { problema }\end{array}$ & $\begin{array}{c}\text { professora } \\
\text { apresenta } \\
\text { métodos de } \\
\text { investigação }\end{array}$ & $\begin{array}{c}\text { professora } \\
\text { indica como } \\
\text { analisar } \\
\text { dados }\end{array}$ & $\begin{array}{c}\text { professora } \\
\text { solicita que } \\
\text { estudantes } \\
\text { apresentem } \\
\text { hipóteses } \\
\text { utilizando } \\
\text { pensamento } \\
\text { matemático } \\
\text { professora } \\
\text { indica como } \\
\text { utilizar } \\
\text { pensamento } \\
\text { matemático }\end{array}$ & $\begin{array}{c}\text { professora } \\
\text { indica } \\
\text { inconsistências } \\
\text { em hipóteses }\end{array}$ \\
\hline
\end{tabular}

Quadro 28 - Episódio 2- Atividade 9- Análise dos dados da tabela - 11/11/2012 
Com o episódio acima, ilustramos as interações entre a professora, os estudantes e a tabela a fim de responder ao primeiro problema proposto. O que é solicitado na questão, assim como nas outras três que a seguem, é que seja feita uma descrição do que houve ao longo das rodadas do jogo. Essas perguntas

são muito parecidas com as perguntas do tipo como: permitem que os estudantes reconstruam a atividade mentalmente, tomando consciência do que ocorreu ao longo da brincadeira. Por isso, elas são extremamente importantes para que os estudantes possam entender a dinâmica das populações. Além disso, com estas perguntas iniciais, os estudantes mantêm contato com a tabela e a leitura da mesma. Para responder a cada uma destas quatro primeiras perguntas, os estudantes terão de fazer associações entre informações contidas em linhas e colunas. (CARVALHO et al, 2011b, p. 32)

A partir do próximo episódio, temos exemplos da resolução da segunda metade do questionário, na qual são apresentadas questões do tipo por que, a fim de que os grupos estabeleçam "relações entre variáveis. São estas perguntas que permitirão aos estudantes construir explicações causais para o fenômeno das populações estudado com os dados do jogo" (CARVALHO et al, 2011b, p. 33). Para guiar os estudantes na construção dessas explicações, a professora opta por fazer perguntas que os ajudam a elaborar justificativas a partir do vivenciado na brincadeira (turno 39) e a retomar informações do jogo para relembrar as relações entre as três espécies ali representadas (turno 60 a 66). Além disso, a professora parafraseia os enunciados apresentados na ficha, utilizando-se de vocabulário e estruturas mais simples (turnos 35 e 39) a fim de facilitar a compreensão dos problemas.

Outras operações que evidenciam a prática de fazer perguntas podem ser encontradas nos turnos dos estudantes, como entre os turnos 22 e 23 quando, ainda que não consigamos ouvir toda a conversa, podemos identificar que um colega pergunta para Manoel sobre como utilizar a ferramenta que tem em mãos. No turno 25 temos a pergunta de Ariel ao testar suas hipóteses sobre a leitura da tabela e, mais ao final da etapa de trabalho em grupos, no turno 63 Suzana questiona a professora sobre sua interpretação dos dados.

Todo esse trabalho com a tabela permite que os estudantes experimentem uma prática central das comunidades científicas, a análise e interpretação de dados. Como explica o NRC (2011), para que os materiais produzidos pela observação e investigação científicas possam ser analisados, é importante que sejam organizados de modo a tornar perceptíveis seus padrões ou as relações entre si. Ao organizar dados brutos em gráficos e tabelas, os membros das comunidades científicas conseguem interpretá-los e utilizá-lo tanto para comunicar suas hipóteses, quanto para prosseguir com suas investigações. De modo semelhante, os estudantes também devem ser desafiados a analisar e interpretar dados 
organizados em diferentes suportes para que se tornem capazes de aplicar conceitos e procedimentos para compreendê-los, estabelecendo e justificando as melhores interpretações.

Neste momento da aula, podemos identificar diferentes maneiras adotadas pela professora a fim de ajudar os estudantes a construir significados para os dados coletados durante o jogo. No turno 21, por exemplo, ela mostra por meio de gestos no ar a maneira como a leitura das colunas e das linhas deve ser feita, o que é retomado no turno 26, quando explica para Ariel que os seres vivos estão organizados nas colunas da tabela enquanto que cada rodada corresponde a uma de suas linhas, de modo que a comparação entre a quantidade de indivíduos de uma espécie ao longo do jogo deve ser feita pela leitura vertical da tabela. Entre os turnos 37 e 39, novamente, a professora indica como utilizar a ferramenta, dessa vez, para relacionar a quantidade de duas espécies diferentes em uma mesma rodada.

Parece-nos que com essas operações da professora constitui-se uma situação de sobreposição das práticas científicas e epistêmicas, como apontado por Jiménez-Aleixandre e Crujeiras (2017). Ao orientar a leitura da tabela, a professora cria oportunidades para que essa seja utilizada com propósitos específicos como o de comparar situações, justificar hipóteses e avaliar o impacto do aumento e da diminuição de indivíduos de uma espécie sobre a outra de modo que os estudantes possam construir sentidos sobre a ferramenta que têm em mãos (dimensão material) e utilizá-la em sua proposição e avaliação de hipóteses (dimensão epistêmica).

Ainda sobre a prática de analisar e interpretar dados, ao longo deste segundo momento, vemos os estudantes solicitarem ajuda para ler a tabela, seja para um colega (turno 23), seja para professora (turno 38), bem como utilizarem a tabela que têm em mãos (turnos 20-21, 23-26, 37-40) e a tabela desenhada na lousa (turno 42) para responder aos problemas propostos. O uso constante da ferramenta e o esforço em compreender como utilizá-la parecem indicar que o grupo partilha o repertório proposto pela SEI, adotando-o para realização da atividade, como é característico das comunidades de práticas.

Analisando as normas vigentes, com o episódio acima podemos destacar que a definição de padrões públicos de análise, neste momento, se caracteriza pela apresentação e negociação de um conjunto de critérios para análise e interpretação dos dados organizados na tabela, como nos turnos 20, 21 e 26, quando a professora indica ao grupo como utilizar a ferramenta para dar suporte à apresentação e análise de novas ideias, ou nos turnos 22 e 23, quando isso é feito entre dois estudantes. Nos episódios seguintes, essa mesma operação pode ser vista em dois turnos da professora (turnos 37 e 39). 
Adotar a ferramenta para resolução dos problemas

\begin{tabular}{|c|c|c|c|c|c|c|c|c|c|}
\hline \multirow[b]{2}{*}{$\begin{array}{c}\text { Turnos } \\
(9,54 "-11 ' 10 ")\end{array}$} & \multicolumn{4}{|c|}{ Evidências de Normas Culturais } & \multicolumn{5}{|c|}{ Evidências de Práticas Culturais } \\
\hline & Fórum & $\begin{array}{l}\text { Receptividade } \\
\text { à Crítica }\end{array}$ & $\begin{array}{c}\text { Padrões } \\
\text { Públicos } \\
\text { de Análise }\end{array}$ & $\begin{array}{l}\text { Igualdade } \\
\text { Moderada }\end{array}$ & $\begin{array}{c}\text { Fazer } \\
\text { Perguntas }\end{array}$ & $\begin{array}{c}\text { Planejar e } \\
\text { Executar } \\
\text { Investigações }\end{array}$ & $\begin{array}{c}\text { Analisar e } \\
\text { Interpretar } \\
\text { Dados }\end{array}$ & $\begin{array}{c}\text { Utilizar } \\
\text { pensamento } \\
\text { matemático e } \\
\text { ferramentas } \\
\text { computacionais }\end{array}$ & $\begin{array}{c}\text { Construir } \\
\text { Explicações }\end{array}$ \\
\hline $\begin{array}{l}\text { 35. Professora: } \\
\text { Assim... "à medida } \\
\text { que o número de } \\
\text { tapitis } \\
\text { AUMENTA... o } \\
\text { número de plantas } \\
\text { aumenta ou } \\
\text { diminui?" quando } \\
\text { tem mais de tapiti... } \\
\text { a planta aumenta } \\
\text { ou diminui... o } \\
\text { número de } \\
\text { plantas... quando } \\
\text { aumenta o número } \\
\text { de tapitis? }\end{array}$ & & & & $\begin{array}{c}\text { professora } \\
\text { solicita } \\
\text { contribuições }\end{array}$ & $\begin{array}{c}\text { professora } \\
\text { apresenta } \\
\text { problema } \\
\text { professora } \\
\text { faz } \\
\text { perguntas } \\
\text { para guiar a } \\
\text { construção } \\
\text { de } \\
\text { explicações }\end{array}$ & & & $\begin{array}{c}\text { professora } \\
\text { solicita que } \\
\text { estudantes } \\
\text { apresentem } \\
\text { hipóteses } \\
\text { utilizando } \\
\text { pensamento } \\
\text { matemático } \\
\text { professora indica } \\
\text { como utilizar } \\
\text { pensamento } \\
\text { matemático }\end{array}$ & $\begin{array}{c}\text { professora } \\
\text { solicita que } \\
\text { estudantes } \\
\text { apresentem } \\
\text { hipóteses }\end{array}$ \\
\hline $\begin{array}{l}\text { 36. Suzana: } \\
\text { Diminui }\end{array}$ & $\begin{array}{l}\text { estudantes } \\
\text { apresentam } \\
\text { hipóteses }\end{array}$ & & & $\begin{array}{c}\text { estudantes } \\
\text { apresentam } \\
\text { contribuições }\end{array}$ & & & $\begin{array}{c}\text { estudantes } \\
\text { analisam } \\
\text { dados }\end{array}$ & $\begin{array}{c}\text { estudantes } \\
\text { apresentam } \\
\text { hipóteses } \\
\text { utilizando } \\
\text { pensamento } \\
\text { matemático }\end{array}$ & $\begin{array}{c}\text { estudantes } \\
\text { apresentam } \\
\text { hipóteses } \\
\text { coerente }\end{array}$ \\
\hline $\begin{array}{l}\text { 37. Professora: } \\
\text { Explique por que } \\
\text { isso acontece... por } \\
\text { que será que tem } \\
\text { hora que aumenta o } \\
\text { número de plantas } \\
\text { e hora que diminui }\end{array}$ & $\begin{array}{l}\text { professora } \\
\text { critica } \\
\text { hipóteses } \\
\text { professora } \\
\text { apresenta } \\
\text { métodos de }\end{array}$ & & $\begin{array}{c}\text { professora } \\
\text { apresenta } \\
\text { critérios } \\
\text { para } \\
\text { análise de } \\
\text { hipóteses }\end{array}$ & $\begin{array}{c}\text { professora } \\
\text { solicita } \\
\text { contribuições }\end{array}$ & $\begin{array}{c}\text { professora } \\
\text { apresenta } \\
\text { problema }\end{array}$ & $\begin{array}{l}\text { professora } \\
\text { solicita que } \\
\text { estudantes } \\
\text { peguem } \\
\text { materiais } \\
\text { professora }\end{array}$ & $\begin{array}{l}\text { professora } \\
\text { indica } \\
\text { como } \\
\text { analisar } \\
\text { dados }\end{array}$ & $\begin{array}{c}\text { professora } \\
\text { solicita que } \\
\text { estudantes } \\
\text { justifiquem } \\
\text { hipóteses } \\
\text { utilizando } \\
\text { pensamento }\end{array}$ & $\begin{array}{c}\text { professora } \\
\text { solicita que } \\
\text { estudantes } \\
\text { justifiquem } \\
\text { hipóteses }\end{array}$ \\
\hline
\end{tabular}




\begin{tabular}{|c|c|c|c|c|c|c|c|c|}
\hline $\begin{array}{l}\text { o número de } \\
\text { tapiti... olha lá a } \\
\text { tabela... tem que } \\
\text { ver a tabela... a } \\
\text { quantidade de } \\
\text { tapitis e a } \\
\text { quantidade de } \\
\text { plantas }\end{array}$ & investigação & & & & $\begin{array}{c}\text { apresenta } \\
\text { métodos de } \\
\text { investigação }\end{array}$ & & matemático & \\
\hline $\begin{array}{l}\text { 38. Suzana: Não sei } \\
\text { ver... ((professora } \\
\text { se aproxima da } \\
\text { estudante)) }\end{array}$ & & & & & & $\begin{array}{c}\text { estudantes } \\
\text { solicitam } \\
\text { ajuda para } \\
\text { analisar } \\
\text { dados }\end{array}$ & $\begin{array}{c}\text { estudantes } \\
\text { solicitam ajuda } \\
\text { para utilizar } \\
\text { pensamento } \\
\text { matemático }\end{array}$ & \\
\hline $\begin{array}{l}\text { 39. Professora: } \\
\text { Quando tem mais } \\
\text { tapiti... quando tem } \\
\text { mais planta... olha } \\
\text { lá... a quantidade de } \\
\text { planta... tem MAIS } \\
\text { ou tem MENOS } \\
\text { tapiti? Diminui ou } \\
\text { aumenta? }\end{array}$ & $\begin{array}{l}\text { professora } \\
\text { apresenta } \\
\text { métodos de } \\
\text { investigação }\end{array}$ & $\begin{array}{l}\text { professora } \\
\text { apresenta } \\
\text { critérios } \\
\text { para } \\
\text { análise de } \\
\text { hipóteses }\end{array}$ & $\begin{array}{c}\text { professora } \\
\text { solicita } \\
\text { contribuições }\end{array}$ & $\begin{array}{l}\text { professora } \\
\text { faz } \\
\text { perguntas } \\
\text { para guiar } \\
\text { construção } \\
\text { de } \\
\text { explicações }\end{array}$ & $\begin{array}{c}\text { professora } \\
\text { solicita que } \\
\text { estudantes } \\
\text { peguem } \\
\text { materiais } \\
\text { professora } \\
\text { apresenta } \\
\text { métodos de } \\
\text { investigação }\end{array}$ & $\begin{array}{l}\text { professora } \\
\text { indica } \\
\text { como } \\
\text { analisar } \\
\text { dados }\end{array}$ & $\begin{array}{c}\text { professora indica } \\
\text { como utilizar } \\
\text { pensamento } \\
\text { matemático } \\
\text { professora } \\
\text { solicita que } \\
\text { estudantes } \\
\text { apresentem } \\
\text { hipóteses } \\
\text { utilizando } \\
\text { pensamento } \\
\text { matemático }\end{array}$ & $\begin{array}{c}\text { professora } \\
\text { solicita que } \\
\text { estudantes } \\
\text { apresentem } \\
\text { hipóteses }\end{array}$ \\
\hline $\begin{array}{l}\text { 40. Suzana: } \\
\text { Aumenta }\end{array}$ & $\begin{array}{l}\text { estudantes } \\
\text { apresentam } \\
\text { hipóteses }\end{array}$ & & $\begin{array}{c}\text { estudantes } \\
\text { apresentam } \\
\text { contribuições }\end{array}$ & & & $\begin{array}{l}\text { estudantes } \\
\text { analisam } \\
\text { dados }\end{array}$ & $\begin{array}{c}\text { estudantes } \\
\text { apresentam } \\
\text { hipóteses } \\
\text { utilizando } \\
\text { pensamento } \\
\text { matemático }\end{array}$ & $\begin{array}{l}\text { estudantes } \\
\text { apresentam } \\
\text { hipóteses } \\
\text { coerentes }\end{array}$ \\
\hline $\begin{array}{l}\text { 41. Professora: por } \\
\text { que será? pensa no } \\
\text { jogo... na }\end{array}$ & $\begin{array}{l}\text { professora } \\
\text { critica } \\
\text { hipóteses }\end{array}$ & & $\begin{array}{c}\text { professora } \\
\text { solicita } \\
\text { contribuições }\end{array}$ & $\begin{array}{l}\text { professora } \\
\text { faz } \\
\text { perguntas }\end{array}$ & & & & $\begin{array}{c}\text { professora } \\
\text { solicita que } \\
\text { estudantes }\end{array}$ \\
\hline
\end{tabular}




\begin{tabular}{|c|c|c|c|c|c|c|c|}
\hline $\begin{array}{l}\text { brincadeira lá... por } \\
\text { que que acontece } \\
\text { isso? }\end{array}$ & & & & $\begin{array}{c}\text { para guiar } \\
\text { construção } \\
\text { de } \\
\text { explicações }\end{array}$ & & & $\begin{array}{l}\text { justifiquem } \\
\text { hipóteses }\end{array}$ \\
\hline $\begin{array}{l}\text { 42. Suzana: } \\
\text { ((Suzana aponta } \\
\text { para a tabela na } \\
\text { lousa)) Porque o } \\
\text { tapiti pode comer } \\
\text { mais planta }\end{array}$ & $\begin{array}{l}\text { estudantes } \\
\text { justificam } \\
\text { hipóteses }\end{array}$ & $\begin{array}{c}\text { estudantes } \\
\text { apresentam } \\
\text { hipóteses } \\
\text { considerando } \\
\text { críticas }\end{array}$ & $\begin{array}{c}\text { estudantes } \\
\text { apresentam } \\
\text { contribuições }\end{array}$ & & $\begin{array}{l}\text { estudantes } \\
\text { analisam } \\
\text { dados }\end{array}$ & $\begin{array}{l}\text { estudantes } \\
\text { apresentam } \\
\text { hipóteses } \\
\text { utilizando } \\
\text { pensamento } \\
\text { matemático }\end{array}$ & $\begin{array}{c}\text { estudantes } \\
\text { apresentam } \\
\text { justificativas } \\
\text { coerentes }\end{array}$ \\
\hline
\end{tabular}

Quadro 29 - Episódio 3- Atividade 9- Análise dos dados da tabela - 11/11/2012 
Prosseguindo com a análise das normas, trazemos exemplos de como a norma de fórum se evidencia neste segundo momento de aula. Em sequências como a ocorrida entre os turnos 40 e 42, temos operações que correspondem à construção de hipóteses, como fora comum nas aulas anteriores, contudo, em decorrência da necessidade de compreender como utilizar a ferramenta disponibilizada na atividade, vemos nessa aula a sala se configurar em um espaço de apresentação, crítica e revisão, não somente de hipótese, mas também de métodos. É o caso do turno 37, no qual a professora apresenta para Suzana que, para investigar as relações entre o número de plantas e tapitis ao longo do jogo, é preciso olhar na tabela a quantidade de indivíduos de cada uma dessas espécies a cada rodada.

Nos turnos 20, 21 e 26 do episódio anterior, encontramos exemplos similares dessa operação quando a professora aponta para as tabelas dos estudantes indicando como localizar as rodadas nas linhas e a quantidade de indivíduos nas colunas da tabela. Aproveitamos a retomada desse episódio para destacar uma operação ocorrida no turno 24: a apresentação de um plano de trabalho. Optamos por diferenciar essas duas operações da professora, pois no referido turno não há indicação de como utilizar a tabela para analisar e interpretar os dados, mas apenas a solicitação de que o estudante pegue o material para realização da investigação, repetindo a instrução dada ao início da aula. Essa operação de apresentar um plano de trabalho, como discutido na análise do primeiro momento da aula, também evidencia a vigência da norma de fórum.

Partindo para a discussão das práticas, uma vez que abordamos a apresentação de métodos de trabalho, podemos falar do planejar e executar investigações que, nas comunidades científicas, envolve a definição de como proceder a coleta de materiais e de como selecionar o que deve ser registrado e considerado como dado a fim de permitir a construção, teste e revisão de explicações. No contexto da aula analisada, como a coleta já fora realizada na atividade anterior, o foco da atividade desenvolvida está na análise dos dados organizados e, para tanto, a professora apresenta algumas instruções para os grupos de como proceder a investigação.

Essa maior diretividade no planejamento e execução da atividade não é considerada como um obstáculo para promoção de práticas ou normas similares às das comunidades científicas em sala de aula, pois nos anos iniciais da escolarização, como apontado nas orientações do NRC (2011), é possível, ou mesmo necessário, que as investigações propostas em sala sejam previamente estruturadas a fim de oferecer elementos para que os estudantes possam, futuramente, planejar e executar uma investigação. Ao longo dos anos escolares, os estudantes devem ganhar autonomia de planejamento, escolhendo desenhos metodológicos e 
lidando com as limitações desses, ou mesmo, com a necessidade de revisão de um plano original.

Tendo isso em vista, podemos dizer que a prática de planejar e executar investigações é evidenciada a cada vez que a professora solicita que os estudantes peguem a tabela e localizem nela as informações necessárias, indicando como associar as informações contidas nas linhas e nas colunas, como vemos, por exemplo, nos turnos 37 e 39 . Outra operação que evidencia essa prática é o mapeamento de condições relevantes para construção de uma explicação para os problemas recebidos, como vemos entre os turnos 60 e 66 do episódio abaixo, no qual a presença de um predador para o tapiti é destacada. A partir dessa vivência orientada pela professora, é possível que os estudantes tenham mais autonomia para o trabalho com tabelas em atividades futuras.

Outra prática evidenciada neste momento é a de utilizar pensamento matemático que, para as comunidades científicas, é central para representação numérica de variáveis, a fim de facilitar a busca por padrões e de viabilizar a identificação de relações entre essas. Na aula analisada, essa prática se evidencia à medida em que a professora solicita aos estudantes a apresentação e a justificativa de hipóteses utilizando-se do repertório matemático e, assim, exige a comparação entre a quantidade de indivíduos de uma espécie ao longo do jogo e o estabelecimento de relações entre as variações sofridas nas diferentes populações. 
Ajudar os estudantes a estabelecer relações entre as variáveis

\begin{tabular}{|c|c|c|c|c|c|c|c|}
\hline \multirow[b]{2}{*}{$\begin{array}{c}\text { Turnos } \\
(12 ’ 30 ”-14 ’ 17 ’)\end{array}$} & \multicolumn{4}{|c|}{ Evidências de Normas Culturais } & \multicolumn{3}{|c|}{ Evidências de Práticas Culturais } \\
\hline & Fórum & $\begin{array}{l}\text { Receptividade à } \\
\text { Crítica }\end{array}$ & $\begin{array}{l}\text { Padrões } \\
\text { Públicos de } \\
\text { Análise }\end{array}$ & $\begin{array}{l}\text { Igualdade } \\
\text { Moderada }\end{array}$ & Fazer Perguntas & $\begin{array}{c}\text { Planejar e } \\
\text { Executar } \\
\text { Investigações }\end{array}$ & $\begin{array}{l}\text { Construir } \\
\text { Explicações }\end{array}$ \\
\hline $\begin{array}{l}\text { 58. Professora: "Além da } \\
\text { disponibilidade de alimento... } \\
\text { que outro fator influenciou o } \\
\text { crescimento da população de } \\
\text { tapitis"... é assim... ele precisa de } \\
\text { planta pra ele }\end{array}$ & & & $\begin{array}{l}\text { professora } \\
\text { apresenta } \\
\text { critérios para } \\
\text { análise de } \\
\text { hipóteses }\end{array}$ & $\begin{array}{l}\text { professora } \\
\text { solicita } \\
\text { contribuições }\end{array}$ & $\begin{array}{l}\text { professora } \\
\text { apresenta } \\
\text { problema }\end{array}$ & & \\
\hline 59. Suzana: Sobreviver & $\begin{array}{l}\text { estudantes } \\
\text { apresentam } \\
\text { hipóteses }\end{array}$ & & & $\begin{array}{l}\text { estudantes } \\
\text { apresentam } \\
\text { contribuições }\end{array}$ & & & $\begin{array}{l}\text { estudantes } \\
\text { apresentam } \\
\text { hipóteses } \\
\text { coerentes }\end{array}$ \\
\hline $\begin{array}{l}\text { 60. Professora: Sobreviver né? } \\
\text { então ...qual o fator que ajudou a } \\
\text { aumentar a população de tapiti... } \\
\text { por que quem é que caçava ele? }\end{array}$ & & & $\begin{array}{l}\text { professora } \\
\text { apresenta } \\
\text { critérios para } \\
\text { análise de } \\
\text { hipóteses }\end{array}$ & $\begin{array}{l}\text { professora } \\
\text { solicita } \\
\text { contribuições }\end{array}$ & $\begin{array}{l}\text { professora faz } \\
\text { pergunta para } \\
\text { guiar } \\
\text { construção de } \\
\text { explicações }\end{array}$ & $\begin{array}{l}\text { professora } \\
\text { mapeia } \\
\text { condições } \\
\text { relevantes }\end{array}$ & $\begin{array}{l}\text { professora } \\
\text { solicita que } \\
\text { estudantes } \\
\text { apresentem } \\
\text { hipóteses }\end{array}$ \\
\hline 61. Suzana: A jaguatirica & $\begin{array}{l}\text { estudantes } \\
\text { apresentam } \\
\text { hipóteses }\end{array}$ & & & $\begin{array}{l}\text { estudantes } \\
\text { apresentam } \\
\text { contribuições }\end{array}$ & & & $\begin{array}{l}\text { estudantes } \\
\text { apresentam } \\
\text { hipóteses } \\
\text { coerente } \\
\end{array}$ \\
\hline $\begin{array}{l}\text { 62. Professora: E se aumentou a } \\
\text { população dele... o que que foi } \\
\text { que aconteceu? }\end{array}$ & & & & $\begin{array}{l}\text { professora } \\
\text { solicita } \\
\text { contribuições }\end{array}$ & $\begin{array}{l}\text { professora faz } \\
\text { perguntas para } \\
\text { guiar } \\
\text { construção de } \\
\text { explicações }\end{array}$ & & $\begin{array}{l}\text { professora } \\
\text { solicita que } \\
\text { estudantes } \\
\text { apresentem } \\
\text { hipóteses }\end{array}$ \\
\hline 63. Suzana: Comeu planta? & $\begin{array}{l}\text { estudantes } \\
\text { apresentam } \\
\text { hipóteses }\end{array}$ & & & $\begin{array}{l}\text { estudantes } \\
\text { apresentam } \\
\text { contribuições }\end{array}$ & $\begin{array}{l}\text { estudantes } \\
\text { fazem } \\
\text { perguntas para } \\
\text { testar hipóteses } \\
\end{array}$ & & $\begin{array}{l}\text { estudantes } \\
\text { apresentam } \\
\text { hipóteses } \\
\text { coerentes } \\
\end{array}$ \\
\hline $\begin{array}{l}\text { 64. Professora: Não... se } \\
\text { aumentou? ele comeu a planta... }\end{array}$ & $\begin{array}{c}\text { professora } \\
\text { critica hipótese }\end{array}$ & & & $\begin{array}{l}\text { professora } \\
\text { rejeita }\end{array}$ & $\begin{array}{l}\text { professora faz } \\
\text { perguntas para }\end{array}$ & & $\begin{array}{l}\text { professora } \\
\text { indica }\end{array}$ \\
\hline
\end{tabular}


e aí... aumentou o número de tapitis... por que que aconteceu isso?

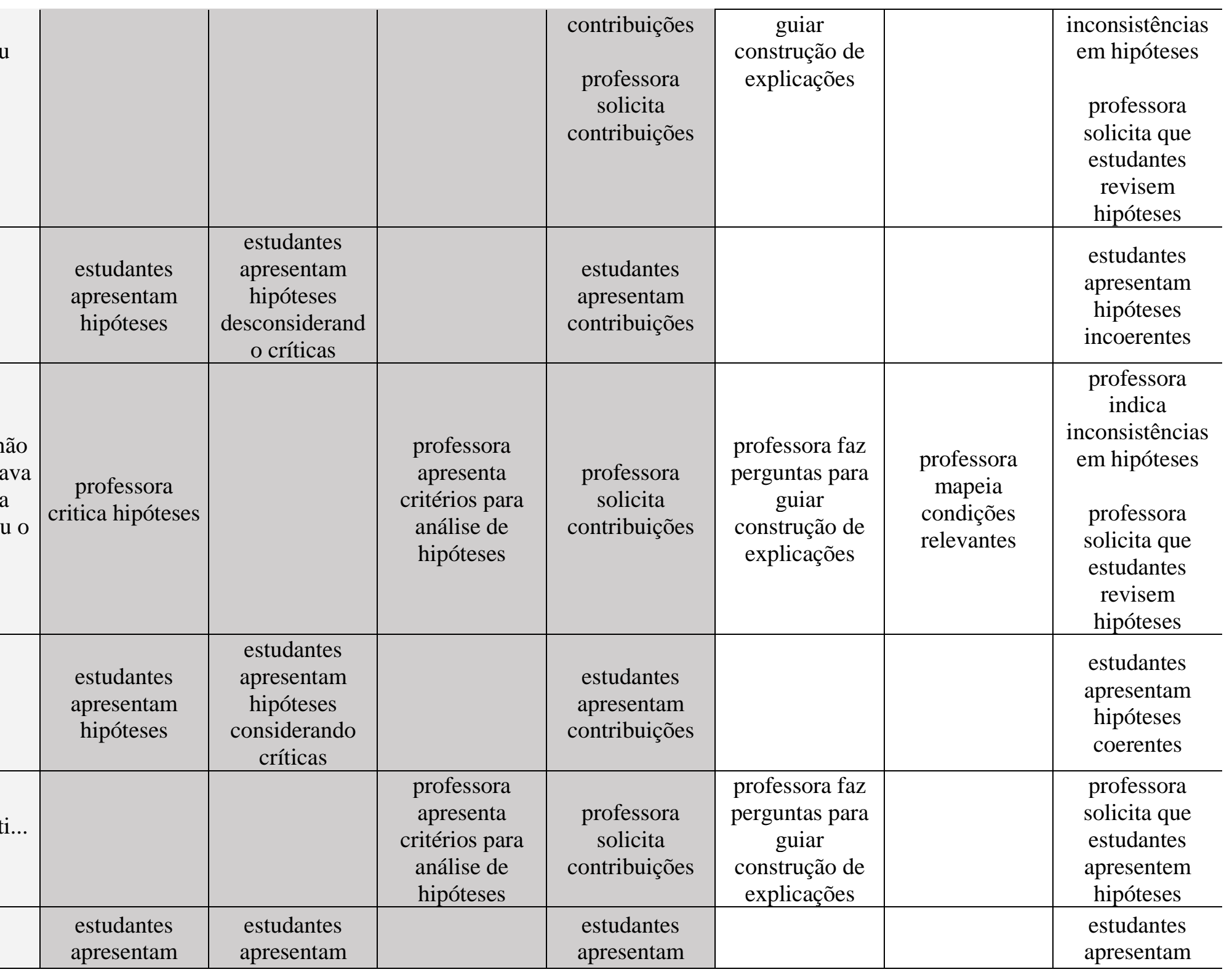

66. Professora: Sim.... mas... não tinha alguém que também caçava ele? ((Suzana balança a cabeça afirmativamente)) se aumentou o número de tapitis...

65. Suzana: Por causa que comeu planta 


\begin{tabular}{|c|c|c|c|c|c|c|}
\hline & hipóteses & $\begin{array}{l}\text { hipóteses } \\
\text { considerando } \\
\text { críticas }\end{array}$ & & contribuições & & $\begin{array}{l}\text { hipóteses } \\
\text { coerentes }\end{array}$ \\
\hline $\begin{array}{l}\text { 70. Professora: Então... se } \\
\text { aumentou a população... o que } \\
\text { que aconteceu? }\end{array}$ & & & & $\begin{array}{l}\text { professora } \\
\text { solicita } \\
\text { contribuições }\end{array}$ & $\begin{array}{l}\text { professora faz } \\
\text { perguntas para } \\
\text { guiar } \\
\text { construção de } \\
\text { explicações }\end{array}$ & $\begin{array}{l}\text { professora } \\
\text { solicita que } \\
\text { estudantes } \\
\text { apresentem } \\
\text { hipóteses }\end{array}$ \\
\hline 71. Rosa: Jaguatirica & $\begin{array}{l}\text { estudantes } \\
\text { revisam } \\
\text { hipóteses }\end{array}$ & $\begin{array}{c}\text { estudantes } \\
\text { apresentam } \\
\text { hipóteses } \\
\text { considerando } \\
\text { críticas } \\
\end{array}$ & & $\begin{array}{l}\text { estudantes } \\
\text { apresentam } \\
\text { contribuições }\end{array}$ & & $\begin{array}{l}\text { estudantes } \\
\text { apresentam } \\
\text { hipóteses } \\
\text { coerentes }\end{array}$ \\
\hline $\begin{array}{l}\text { 72. Professora: Sim... mas por } \\
\text { que que aumentou? }\end{array}$ & & & & $\begin{array}{l}\text { professora } \\
\text { solicita } \\
\text { contribuições }\end{array}$ & $\begin{array}{l}\text { professora faz } \\
\text { perguntas para } \\
\text { guiar } \\
\text { construção de } \\
\text { explicações }\end{array}$ & $\begin{array}{c}\text { professora } \\
\text { solicita que } \\
\text { estudantes } \\
\text { apresentem } \\
\text { hipóteses }\end{array}$ \\
\hline 73. Rosa: Por que sobreviveu & $\begin{array}{l}\text { estudantes } \\
\text { revisam } \\
\text { hipóteses }\end{array}$ & $\begin{array}{c}\text { estudantes } \\
\text { apresentam } \\
\text { hipóteses } \\
\text { considerando } \\
\text { críticas } \\
\end{array}$ & & $\begin{array}{l}\text { estudantes } \\
\text { apresentam } \\
\text { contribuições }\end{array}$ & & $\begin{array}{l}\text { estudantes } \\
\text { apresentam } \\
\text { hipóteses } \\
\text { coerentes }\end{array}$ \\
\hline $\begin{array}{l}\text { 74. Professora: Mas por que que } \\
\text { ele sobreviveu? além de comer a } \\
\text { planta }\end{array}$ & & & $\begin{array}{c}\text { professora } \\
\text { apresenta } \\
\text { critérios para } \\
\text { análise de } \\
\text { hipóteses }\end{array}$ & $\begin{array}{l}\text { professora } \\
\text { solicita } \\
\text { contribuições }\end{array}$ & $\begin{array}{l}\text { professora faz } \\
\text { perguntas para } \\
\text { guiar } \\
\text { construção de } \\
\text { explicações }\end{array}$ & $\begin{array}{c}\text { professora } \\
\text { solicita que } \\
\text { estudantes } \\
\text { justifiquem } \\
\text { hipóteses }\end{array}$ \\
\hline $\begin{array}{l}\text { 75. Rosa: A jaguatirica não } \\
\text { pegou ele }\end{array}$ & $\begin{array}{l}\text { estudantes } \\
\text { justificam } \\
\text { hipóteses }\end{array}$ & & & $\begin{array}{l}\text { estudantes } \\
\text { apresentam } \\
\text { contribuições }\end{array}$ & & $\begin{array}{c}\text { estudantes } \\
\text { apresentam } \\
\text { justificativas } \\
\text { coerentes }\end{array}$ \\
\hline
\end{tabular}

Quadro 30 - Episódio 4- Atividade 9- Análise dos dados da tabela - 11/11/2012 
Com o episódio acima, ilustramos algumas operações que evidenciam a constituição da receptividade à crítica no segundo momento dessa aula. Em uma primeira situação, logo no início do episódio, Suzana responde à sexta questão desconsiderando a condição apresentada no enunciado e afirma que o aumento de tapitis está relacionado ao consumo de plantas, ou seja, à disponibilidade de alimento. Em seguida, mesmo que a professora rejeite sua resposta (turno 64), a estudante insiste na ideia (turno 65) e repete sua hipótese, desconsiderando as críticas realizadas. Entretanto, a partir do turno 66, conforme Rosa e Suzana revisam a hipótese inicial a partir das avaliações feitas pela professora, identificamos uma situação distinta na qual a receptividade à crítica está presente e resulta na construção de uma explicação coerente para o problema, como evidenciado no turno 75 , quando Rosa apresenta a hipótese de que o crescimento da população de tapitis se deu, pois, "A jaguatirica não pegou ele". No turno 42, temos outro exemplo de como essas mesmas estudantes recebem as críticas feitas pela professora (turno 39), dessa vez com relação à maneira de utilizar a tabela, e de como essas reformulam suas ideias, seguindo com a interpretação dos dados a partir das instruções dadas pela professora.

Evidenciando a norma de padrões públicos de análise, no episódio acima ilustramos como a professora destaca uma condição do jogo que deve ser considerada para análise do aumento e a diminuição da população de tapiti: a presença de um predador. Para tanto, ao ajudar Rosa e Suzana a responder a sexta questão, por perceber que as estudantes estão presas à relação entre o consumo de plantas e o aumento da população de tapitis, a professora pergunta "quem é que caçava ele?” (turno 60), "não tinha alguém que também caçava ele?" (turno 66), estabelecendo com as estudantes um critério a ser considerado para apresentação de novas ideias.

Como última norma a ser analisada no segundo momento da aula, temos a constituição de igualdade moderada que se evidencia pelas constantes solicitação e apresentação de contribuições pelos estudantes. Essas contribuições, como sintetizado abaixo, são aproveitadas pela professora que, por meio de perguntas e pela apresentação de inconsistências e de critérios para apresentação de novas ideias, ajuda os estudantes a articularem hipóteses fragmentadas em uma explicação baseada nos dados do jogo.

Os tapitis precisam de plantas para sobreviver e esse recurso estava disponível e foi consumido (turnos 58 a 60 e 62 a 65 )

As jaguatiricas caçam os tapitis e, se elas os tivessem pego, a população de tapitis 
não teria aumentado (turnos 66 a 69)

Se a população de tapitis aumentou, foi porque as jaguatiricas não os pegaram e eles sobreviveram (turnos 70 a 75)

Figura 12 - Explicação construída durante a resolução dos problemas propostos na Aula 8- Análise dos dados da tabela

Negociações como essa, podem ser vistas em outras passagens dessa aula, como o intervalo entre os turnos 124 e 130, e evidenciam como a professora e os estudantes discutem e estabelecem critérios para definir aquilo que é relevante para resolução do problema, para estabelecer que ideias podem ser tomadas como pressupostos ou para decidir como melhor dispor da ferramenta que têm em mãos. Interpretamos essas situações como um elemento que nos permite caracterizar a sala como uma comunidade de práticas durante essa aula: a identificação com o projeto, construída à medida em que membros de uma comunidade negociam formas de trabalhar de maneira coordenada a fim de realizar seus projetos da melhor forma possível.

5.3.3 A partilha dos resultados

Para iniciar a partilha dos resultados encontrados pelos grupos, a professora se dirige à frente da sala e pede a atenção de todos, propondo que analisem a tabela juntos a partir das respostas que foram encontradas. 
Explorar, coletivamente, os dados da tabela

\begin{tabular}{|c|c|c|c|c|c|c|c|c|}
\hline \multirow[b]{2}{*}{$\begin{array}{l}\text { Turnos } \\
(20 ’ 58 "- \\
21 " 23)\end{array}$} & \multicolumn{4}{|c|}{ Evidências de Normas Culturais } & \multicolumn{4}{|c|}{ Evidências de Práticas Culturais } \\
\hline & Fórum & $\begin{array}{l}\text { Receptividade à } \\
\text { Crítica }\end{array}$ & $\begin{array}{c}\text { Padrões } \\
\text { Públicos de } \\
\text { Análise }\end{array}$ & $\begin{array}{l}\text { Igualdade } \\
\text { Moderada }\end{array}$ & $\begin{array}{c}\text { Fazer } \\
\text { Perguntas }\end{array}$ & $\begin{array}{l}\text { Analisar e } \\
\text { Interpretar } \\
\text { Dados }\end{array}$ & $\begin{array}{c}\text { Utilizar pensamento } \\
\text { matemático e } \\
\text { ferramentas } \\
\text { computacionais }\end{array}$ & $\begin{array}{c}\text { Construir } \\
\text { Explicações }\end{array}$ \\
\hline $\begin{array}{l}\text { 87. Professora: } \\
\text { "Um... em que } \\
\text { rodada o } \\
\text { número de } \\
\text { plantas foi } \\
\text { maior?" }\end{array}$ & & & & $\begin{array}{c}\text { professora } \\
\text { solicita } \\
\text { contribuições }\end{array}$ & $\begin{array}{c}\text { professora } \\
\text { apresenta } \\
\text { problema }\end{array}$ & & $\begin{array}{c}\text { professora solicita } \\
\text { que estudantes } \\
\text { apresentem hipóteses } \\
\text { utilizando } \\
\text { pensamento } \\
\text { matemático } \\
\end{array}$ & $\begin{array}{c}\text { professora } \\
\text { solicita que } \\
\text { estudantes } \\
\text { apresentem } \\
\text { hipóteses }\end{array}$ \\
\hline $\begin{array}{l}\text { 88. Estudantes: } \\
\text { Onze }\end{array}$ & $\begin{array}{c}\text { estudantes } \\
\text { apresentam } \\
\text { hipóteses }\end{array}$ & & & $\begin{array}{c}\text { estudantes } \\
\text { apresentam } \\
\text { contribuições }\end{array}$ & & $\begin{array}{l}\text { estudantes } \\
\text { analisam } \\
\text { dados }\end{array}$ & $\begin{array}{c}\text { estudantes } \\
\text { apresentam hipóteses } \\
\text { utilizando } \\
\text { pensamento } \\
\text { matemático } \\
\end{array}$ & $\begin{array}{l}\text { estudantes } \\
\text { apresentam } \\
\text { hipóteses } \\
\text { coerentes }\end{array}$ \\
\hline $\begin{array}{l}\text { 89. Professora: } \\
\text { Em que } \\
\text { RODADA, o } \\
\text { número de } \\
\text { plantas foi } \\
\text { maior? }\end{array}$ & $\begin{array}{l}\text { professora } \\
\text { critica } \\
\text { hipóteses }\end{array}$ & & $\begin{array}{l}\text { professora } \\
\text { apresenta } \\
\text { critérios para } \\
\text { análise de } \\
\text { hipóteses }\end{array}$ & $\begin{array}{c}\text { professora } \\
\text { ignora } \\
\text { contribuições } \\
\\
\text { professora } \\
\text { solicita } \\
\text { contribuições }\end{array}$ & $\begin{array}{c}\text { professora } \\
\text { apresenta } \\
\text { problema }\end{array}$ & $\begin{array}{c}\text { professora } \\
\text { indica como } \\
\text { analisar } \\
\text { dados }\end{array}$ & $\begin{array}{c}\text { professora solicita } \\
\text { que estudantes } \\
\text { apresentem hipóteses } \\
\text { utilizando } \\
\text { pensamento } \\
\text { matemático }\end{array}$ & $\begin{array}{c}\text { professora } \\
\text { solicita que } \\
\text { estudantes } \\
\text { apresentem } \\
\text { hipóteses }\end{array}$ \\
\hline $\begin{array}{l}\text { 90. Estudantes: } \\
\text { Onze }\end{array}$ & $\begin{array}{l}\text { estudantes } \\
\text { apresentam } \\
\text { hipóteses }\end{array}$ & $\begin{array}{c}\text { estudantes } \\
\text { apresentam } \\
\text { hipóteses } \\
\text { desconsiderando } \\
\text { críticas }\end{array}$ & & $\begin{array}{c}\text { estudantes } \\
\text { apresentam } \\
\text { contribuições }\end{array}$ & & $\begin{array}{l}\text { estudantes } \\
\text { analisam } \\
\text { dados }\end{array}$ & $\begin{array}{c}\text { estudantes } \\
\text { apresentam hipóteses } \\
\text { utilizando } \\
\text { pensamento } \\
\text { matemático }\end{array}$ & $\begin{array}{l}\text { estudantes } \\
\text { apresentam } \\
\text { hipóteses } \\
\text { coerentes }\end{array}$ \\
\hline $\begin{array}{l}\text { 91. Rosa: } \\
\text { Quarta e a } \\
\text { quinta }\end{array}$ & $\begin{array}{c}\text { estudantes } \\
\text { revisam } \\
\text { hipóteses }\end{array}$ & $\begin{array}{l}\text { estudantes } \\
\text { apresentam } \\
\text { hipóteses } \\
\text { considerando } \\
\text { críticas } \\
\end{array}$ & & $\begin{array}{c}\text { estudantes } \\
\text { apresentam } \\
\text { contribuições }\end{array}$ & & $\begin{array}{l}\text { estudantes } \\
\text { analisam } \\
\text { dados }\end{array}$ & $\begin{array}{c}\text { estudantes } \\
\text { apresentam hipóteses } \\
\text { utilizando } \\
\text { pensamento } \\
\text { matemático } \\
\end{array}$ & $\begin{array}{l}\text { estudantes } \\
\text { apresentam } \\
\text { hipóteses } \\
\text { coerentes }\end{array}$ \\
\hline 92. Professora: & professora & & & professora & professora faz & & professora solicita & professora \\
\hline
\end{tabular}




\begin{tabular}{|c|c|c|c|c|c|c|}
\hline $\begin{array}{l}\text { Quarta e quinta } \\
\text { né? por quê? }\end{array}$ & $\begin{array}{c}\text { critica } \\
\text { hipóteses }\end{array}$ & $\begin{array}{c}\text { solicita } \\
\text { contribuições }\end{array}$ & $\begin{array}{l}\text { perguntas para } \\
\text { guiar } \\
\text { construção de } \\
\text { explicações }\end{array}$ & & $\begin{array}{c}\text { que estudantes } \\
\text { justifiquem hipóteses } \\
\text { utilizando } \\
\text { pensamento } \\
\text { matemático }\end{array}$ & $\begin{array}{c}\text { solicita que } \\
\text { estudantes } \\
\text { apresentem } \\
\text { justificativa }\end{array}$ \\
\hline $\begin{array}{l}\text { 93. Estudante: } \\
\text { Os dois têm } \\
\text { onze }\end{array}$ & $\begin{array}{l}\text { estudantes } \\
\text { justificam } \\
\text { hipóteses }\end{array}$ & $\begin{array}{l}\text { estudantes } \\
\text { apresentam } \\
\text { contribuições }\end{array}$ & & $\begin{array}{l}\text { estudantes } \\
\text { analisam } \\
\text { dados }\end{array}$ & $\begin{array}{c}\text { estudantes justificam } \\
\text { hipóteses utilizando } \\
\text { pensamento } \\
\text { matemático }\end{array}$ & $\begin{array}{c}\text { estudantes } \\
\text { apresentam } \\
\text { justificativas } \\
\text { coerentes } \\
\end{array}$ \\
\hline $\begin{array}{l}\text { 94. Estudante: } \\
\text { A mesma } \\
\text { quantidade }\end{array}$ & $\begin{array}{l}\text { estudantes } \\
\text { justificam } \\
\text { hipóteses }\end{array}$ & $\begin{array}{l}\text { estudantes } \\
\text { apresentam } \\
\text { contribuições }\end{array}$ & & $\begin{array}{l}\text { estudantes } \\
\text { analisam } \\
\text { dados }\end{array}$ & $\begin{array}{l}\text { estudantes justificam } \\
\text { hipóteses utilizando } \\
\text { pensamento } \\
\text { matemático }\end{array}$ & $\begin{array}{c}\text { estudantes } \\
\text { apresentam } \\
\text { justificativas } \\
\text { coerentes }\end{array}$ \\
\hline
\end{tabular}

Quadro 31 - Episódio 5- Atividade 9- Análise dos dados da tabela - 11/11/2012 
Durante a análise do terceiro momento dessa aula, identificamos evidências de que as normas culturais para construção de explicações científicas para os problemas propostos estão presentes e organizam a participação durante o debate. Nesse sentido, podem ser destacadas contribuições individuais e coletivas nos turnos dos estudantes e intervenções da professora que nos permitem caracterizar que, ao longo da partilha dos resultados, a sala se configurou como um fórum de apresentação, crítica e revisão das hipóteses construídas pelos grupos. Esse processo pode ser exemplificado pelo episódio acima, durante o qual hipóteses para resolução do primeiro problema são apresentadas por alguns estudantes, criticadas pela professora que solicita justificativas e revisadas pelos estudantes que explicitam o raciocínio utilizado para resolução do problema.

Para conduzir a revisão de hipóteses, no turno 89, a professora indica, pelo tom de voz, um critério (padrões públicos de análise) para construção explicações: nomear rodadas e não a quantidade de indivíduos da espécie. Operações similares a essa já haviam sido vistas nas outras aulas, tanto durante a apresentação do problema, quanto durante a leitura dos textos.

Em seguida ao estabelecimento do padrão de análise, a professora ignora as contribuições que não adotam o critério indicado (turno 90), repetindo que a resposta correta seria "quarta e quinta" (turno 92). Essa operação de ignorar contribuições também já fora identificada em outros contextos com duas funções distintas, ora para evitar dispersão ou interrupção do turno da professora, ora, como é nesse caso, para conduzir a construção de uma explicação, ao selecionar e ressaltar algumas hipóteses. Nessa sequência de interações, como vemos em outros turnos da aula, a professora insiste para que os estudantes não nomeiem as rodadas com os dados que foram registrados nessas (turno 82) ou com os números cardinais (turnos 51, 79 e 97), mas sim com os números ordinais, utilizando-se, assim, de um repertório específico. Contudo, ao perceber que os estudantes não adotaram os termos desejados, a professora chega a solicitar (turno 103) "Terceira::: gente... ali tá os números ordinais primeiro... segundo... terceiro... quarto... quinto... sexto...sétimo...”. Como consequência, após essa intervenção, a turma segue oscilando entre o emprego de números ordinais e cardinais em suas respostas, mas a quantidade de indivíduos de uma espécie na rodada não é mais utilizada para nomeá-la. Nessa preocupação com o emprego da nomenclatura adequada, localizamos a função comunicativa da prática de utilizar pensamento matemático que consiste em empregar a matemática como uma das linguagens das ciências (NRC, 2011). 
Dentre as operações que evidenciam a prática de analisar e interpretar dados neste momento, temos a construção de hipóteses e justificativas pela turma à medida em que a leitura da tabela é realizada e as indicações da professora de como fazer uso adequado da ferramenta disponibilizada pela SEI. Acompanhando o desenvolvimento dessa prática ao longo da aula, percebemos que os estudantes, aos poucos, passam a dominar a ferramenta tabela, sendo capazes de localizar dados nas linhas e colunas e de estabelecer relações entre esses a fim de construir explicações coerentes e justificadas. A prática de analisar e interpretar dados se repete ao longo de todo o terceiro momento, a cada vez em que uma pergunta é apresentada pela professora e os estudantes buscam respondê-la a partir dos dados reunidos, observando, apontando, comentando, enfim, adotando a tabela como parte de seu repertório.

Após a discussão das oito perguntas, a professora apresenta uma situação hipotética que deve ser interpretada a partir dos padrões observados na tabela, como analisamos a seguir. 
Construir explicações causais a partir da análise dos dados do jogo

\begin{tabular}{|c|c|c|c|c|c|c|c|c|}
\hline \multirow[b]{2}{*}{$\begin{array}{c}\text { Turnos } \\
\left(29,14 ",-311^{\prime \prime 33)}\right.\end{array}$} & \multicolumn{4}{|c|}{ Evidências de Normas Culturais } & \multicolumn{4}{|c|}{ Evidências de Normas Culturais } \\
\hline & Fórum & $\begin{array}{l}\text { Receptividade } \\
\text { à Crítica }\end{array}$ & $\begin{array}{l}\text { Padrões } \\
\text { Públicos de } \\
\text { Análise }\end{array}$ & $\begin{array}{l}\text { Igualdade } \\
\text { Moderada }\end{array}$ & $\begin{array}{c}\text { Fazer } \\
\text { Perguntas }\end{array}$ & $\begin{array}{c}\text { Desenvolver e } \\
\text { Utilizar } \\
\text { Modelos }\end{array}$ & $\begin{array}{c}\text { Planejar e } \\
\text { Executar } \\
\text { Investigações }\end{array}$ & $\begin{array}{c}\text { Construir } \\
\text { Explicações }\end{array}$ \\
\hline $\begin{array}{l}\text { 160. Professora: Certo.... } \\
\text { aqui só tinha uma planta... } \\
\text { se fosse lá um tapiti e } \\
\text { comesse essa planta e num } \\
\text { ficasse nenhuma planta... e } \\
\text { ainda ficassem sete } \\
\text { tapitis... o que que ia } \\
\text { acontecer? }\end{array}$ & & & & $\begin{array}{c}\text { professora } \\
\text { solicita } \\
\text { contribuições }\end{array}$ & $\begin{array}{l}\text { professora } \\
\text { apresenta } \\
\text { problema }\end{array}$ & & $\begin{array}{l}\text { professora } \\
\text { mapeia } \\
\text { condições } \\
\text { relevantes }\end{array}$ & $\begin{array}{l}\text { professora } \\
\text { solicita que } \\
\text { estudantes } \\
\text { apresentem } \\
\text { hipóteses }\end{array}$ \\
\hline $\begin{array}{l}\text { 161. Fabrício: A } \\
\text { jaguatirica tinha pegado os } \\
\text { tapitis... só que }\end{array}$ & & & & $\begin{array}{c}\text { estudantes } \\
\text { apresentam } \\
\text { contribuições }\end{array}$ & & & & \\
\hline $\begin{array}{l}\text { 162. Professora: Tá... mas } \\
\text { antes da: da jaguatirica } \\
\text { pegar os tapitis... tava lá... }\end{array}$ & & & $\begin{array}{c}\text { professora } \\
\text { apresenta } \\
\text { critérios para } \\
\text { análise de } \\
\text { hipóteses }\end{array}$ & $\begin{array}{l}\text { professora } \\
\text { interrompe } \\
\text { contribuições }\end{array}$ & & & $\begin{array}{l}\text { professora } \\
\text { mapeia } \\
\text { condições } \\
\text { relevantes }\end{array}$ & \\
\hline 163. Fabrício: Sim... eu sei & & & & & & & & \\
\hline $\begin{array}{l}\text { 164. Professora: Os tapitis } \\
\text { têm... por exemplo... } \\
\text { acabou... chegou o } \\
\text { primeiro tapiti lá e comeu } \\
\text { a planta... ainda ficaram } \\
\text { SEI tapitis sem comer } \\
\text { planta FÁBIO... acabou a } \\
\text { planta... e aí... o que será } \\
\text { que ia acontecer com esses } \\
\text { SEI tapitis... esquece a } \\
\text { jaguatirica por enquanto... } \\
\text { o que que ia acontecer com } \\
\text { esses SEI tapitis... se não }\end{array}$ & & & $\begin{array}{c}\text { professora } \\
\text { apresenta } \\
\text { critérios para } \\
\text { análise de } \\
\text { hipóteses }\end{array}$ & $\begin{array}{c}\text { professora } \\
\text { chama atenção } \\
\text { de estudantes } \\
\text { professora } \\
\text { solicita } \\
\text { contribuições }\end{array}$ & $\begin{array}{c}\text { professora faz } \\
\text { perguntas para } \\
\text { guiar } \\
\text { construção de } \\
\text { explicações }\end{array}$ & & $\begin{array}{c}\text { professora } \\
\text { mapeia } \\
\text { condições } \\
\text { relevantes }\end{array}$ & $\begin{array}{l}\text { professora } \\
\text { solicita que } \\
\text { estudantes } \\
\text { apresentem } \\
\text { hipóteses }\end{array}$ \\
\hline
\end{tabular}




\begin{tabular}{|c|c|c|c|c|c|c|c|c|}
\hline \multicolumn{9}{|l|}{ tivesse nenhuma planta? } \\
\hline $\begin{array}{l}\text { 165. Estudantes: Ia virar } \\
\text { planta }\end{array}$ & $\begin{array}{l}\text { estudantes } \\
\text { apresentam } \\
\text { hipóteses }\end{array}$ & & & $\begin{array}{l}\text { estudantes } \\
\text { apresentam } \\
\text { contribuições }\end{array}$ & & & & $\begin{array}{l}\text { estudantes } \\
\text { apresentam } \\
\text { hipóteses } \\
\text { coerentes } \\
\end{array}$ \\
\hline 167. Rosa: Ele ia morre::: & $\begin{array}{l}\text { estudantes } \\
\text { revisam } \\
\text { hipóteses }\end{array}$ & $\begin{array}{c}\text { estudantes } \\
\text { apresentam } \\
\text { hipóteses } \\
\text { considerando } \\
\text { críticas } \\
\end{array}$ & & $\begin{array}{l}\text { professora } \\
\text { solicita } \\
\text { contribuições }\end{array}$ & & $\begin{array}{c}\text { estudantes } \\
\text { apresentam } \\
\text { interpretações } \\
\text { baseadas no } \\
\text { jogo }\end{array}$ & & $\begin{array}{l}\text { estudantes } \\
\text { apresentam } \\
\text { hipóteses } \\
\text { coerentes }\end{array}$ \\
\hline 169. Rosa: Ele ia morrer & $\begin{array}{l}\text { estudantes } \\
\text { apresentam } \\
\text { hipóteses }\end{array}$ & $\begin{array}{c}\text { estudantes } \\
\text { apresentam } \\
\text { hipóteses } \\
\text { considerando } \\
\text { críticas } \\
\end{array}$ & & $\begin{array}{l}\text { professora } \\
\text { solicita } \\
\text { contribuições }\end{array}$ & & $\begin{array}{c}\text { estudantes } \\
\text { apresentam } \\
\text { interpretações } \\
\text { baseadas no } \\
\text { jogo }\end{array}$ & & $\begin{array}{l}\text { estudantes } \\
\text { apresentam } \\
\text { hipóteses } \\
\text { coerentes }\end{array}$ \\
\hline $\begin{array}{l}\text { 170. Professora: Ele ia } \\
\text { morrer... por que? }\end{array}$ & $\begin{array}{l}\text { professora } \\
\text { critica } \\
\text { hipóteses }\end{array}$ & & & $\begin{array}{l}\text { professora } \\
\text { solicita } \\
\text { contribuições }\end{array}$ & $\begin{array}{c}\text { professora faz } \\
\text { pergunta para } \\
\text { guiar } \\
\text { construção de } \\
\text { explicações } \\
\end{array}$ & $\begin{array}{c}\text { professora } \\
\text { solicita } \\
\text { interpretações } \\
\text { baseadas no } \\
\text { jogo } \\
\end{array}$ & & $\begin{array}{c}\text { professora } \\
\text { solicita que } \\
\text { estudantes } \\
\text { apresentem } \\
\text { justificativas }\end{array}$ \\
\hline
\end{tabular}




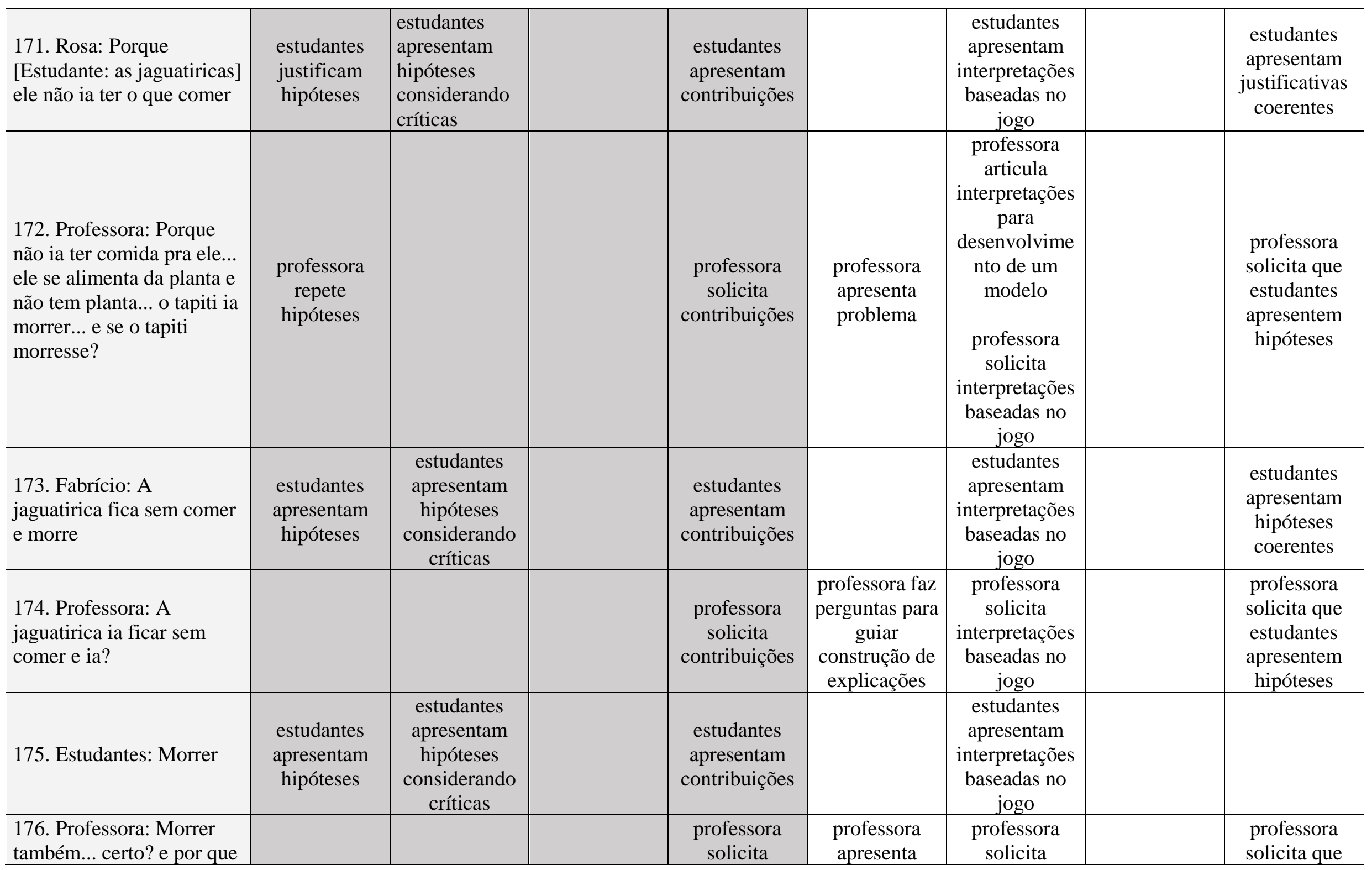




\begin{tabular}{|c|c|c|c|c|c|c|c|c|}
\hline $\begin{array}{l}\text { que quando os tapitis } \\
\text { comiam a planta... } \\
\text { aumentava o número de } \\
\text { tapitis? }\end{array}$ & & & & contribuições & problema & $\begin{array}{c}\text { interpretações } \\
\text { baseadas no } \\
\text { jogo }\end{array}$ & & $\begin{array}{l}\text { estudantes } \\
\text { apresentem } \\
\text { hipóteses }\end{array}$ \\
\hline $\begin{array}{l}\text { 177. Estudantes: Eles iam } \\
\text { engordar mais... }\end{array}$ & $\begin{array}{l}\text { estudantes } \\
\text { apresentam } \\
\text { hipóteses }\end{array}$ & $\begin{array}{l}\text { estudantes } \\
\text { apresentam } \\
\text { hipóteses } \\
\text { considerando } \\
\text { críticas } \\
\end{array}$ & & $\begin{array}{l}\text { estudantes } \\
\text { apresentam } \\
\text { contribuições }\end{array}$ & & $\begin{array}{c}\text { estudantes } \\
\text { apresentam } \\
\text { interpretações } \\
\text { baseadas no } \\
\text { jogo } \\
\end{array}$ & & $\begin{array}{l}\text { estudantes } \\
\text { apresentam } \\
\text { hipóteses } \\
\text { coerentes }\end{array}$ \\
\hline $\begin{array}{l}\text { 179. Professora: Sim... } \\
\text { mas assim... pensando no } \\
\text { bichinho de verdade... por } \\
\text { que será que aumenta o } \\
\text { número de tapiti quando } \\
\text { ele se alimenta? }\end{array}$ & $\begin{array}{l}\text { professora } \\
\text { critica } \\
\text { hipóteses }\end{array}$ & & $\begin{array}{l}\text { professora } \\
\text { apresenta } \\
\text { critérios para } \\
\text { análise de } \\
\text { hipóteses }\end{array}$ & $\begin{array}{l}\text { professora } \\
\text { solicita } \\
\text { contribuições }\end{array}$ & $\begin{array}{l}\text { professora faz } \\
\text { perguntas para } \\
\text { guiar } \\
\text { construção de } \\
\text { explicações }\end{array}$ & $\begin{array}{c}\text { professora } \\
\text { solicita } \\
\text { interpretações } \\
\text { baseadas no } \\
\text { jogo }\end{array}$ & $\begin{array}{l}\text { professora } \\
\text { mapeia } \\
\text { condições } \\
\text { relevantes }\end{array}$ & \begin{tabular}{|c|} 
professora \\
indica \\
inconsistência \\
s em hipóteses \\
\\
professora \\
solicita que \\
estudantes \\
apresentem \\
hipóteses \\
\end{tabular} \\
\hline $\begin{array}{l}\text { 180. Irene: Porque nasce } \\
\text { mais tapiti }\end{array}$ & $\begin{array}{l}\text { estudantes } \\
\text { apresentam } \\
\text { hipóteses }\end{array}$ & $\begin{array}{l}\text { estudantes } \\
\text { apresentam } \\
\text { hipóteses } \\
\text { considerando } \\
\text { críticas }\end{array}$ & & $\begin{array}{l}\text { estudantes } \\
\text { apresentam } \\
\text { contribuições }\end{array}$ & & $\begin{array}{c}\text { estudantes } \\
\text { apresentam } \\
\text { interpretações } \\
\text { baseadas no } \\
\text { jogo }\end{array}$ & & $\begin{array}{l}\text { estudantes } \\
\text { apresentam } \\
\text { hipóteses } \\
\text { coerente }\end{array}$ \\
\hline $\begin{array}{l}\text { 181. Professora: Porque } \\
\text { nasce mais tapiti... a:.: } \\
\text { porque ele se alimenta... } \\
\text { ele fica forte... aí a tapiti } \\
\text { fêmea vai lá... namora o } \\
\text { tapiti macho né? e aí o que } \\
\text { que acontece? o que }\end{array}$ & $\begin{array}{l}\text { professora } \\
\text { repete } \\
\text { hipóteses }\end{array}$ & & & $\begin{array}{l}\text { professora } \\
\text { solicita } \\
\text { contribuições }\end{array}$ & $\begin{array}{c}\text { professora faz } \\
\text { perguntas para } \\
\text { guiar } \\
\text { construção de } \\
\text { explicações }\end{array}$ & $\begin{array}{c}\text { professora } \\
\text { articula } \\
\text { interpretações } \\
\text { para } \\
\text { desenvolvime } \\
\text { nto de um } \\
\text { modelo }\end{array}$ & & $\begin{array}{l}\text { professora } \\
\text { solicita que } \\
\text { estudantes } \\
\text { apresentem } \\
\text { hipóteses }\end{array}$ \\
\hline
\end{tabular}




\begin{tabular}{|c|c|c|c|c|c|}
\hline acontece? & & & & $\begin{array}{c}\text { professora } \\
\text { solicita } \\
\text { interpretações } \\
\text { baseadas no } \\
\text { jogo }\end{array}$ & \\
\hline $\begin{array}{l}\text { 182. Irene: Aí tem } \\
\text { filhote... }\end{array}$ & $\begin{array}{l}\text { estudantes } \\
\text { apresentam } \\
\text { hipóteses }\end{array}$ & $\begin{array}{l}\text { estudantes } \\
\text { apresentam } \\
\text { hipóteses } \\
\text { considerando } \\
\text { críticas }\end{array}$ & $\begin{array}{l}\text { estudantes } \\
\text { apresentam } \\
\text { contribuições }\end{array}$ & $\begin{array}{c}\text { estudantes } \\
\text { apresentam } \\
\text { interpretações } \\
\text { baseadas no } \\
\text { jogo } \\
\end{array}$ & $\begin{array}{c}\text { estudantes } \\
\text { apresentam } \\
\text { hipóteses } \\
\text { coerentes }\end{array}$ \\
\hline
\end{tabular}

Quadro 32 - Episódio 6- Atividade 9- Análise dos dados da tabela - 11/11/2012 
Iniciamos a discussão do episódio acima pela prática de fazer perguntas que aqui assume um papel central na extrapolação do que fora vivido no jogo a fim de subsidiar a construção de um modelo explicativo sobre a dinâmica de populações baseado nas relações discutidas durante a análise dos dados da tabela. O primeiro problema proposto pela professora está no turno 160, quando ela questiona sobre as consequências da extinção das plantas, sendo seguida por outros dois problemas apresentados nos turnos 172 e 176 e que iniciam discussões sobre as consequências da extinção do tapiti e sobre as relações entre as populações de tapitis e de plantas.

Para guiar a construção de explicações para esses problemas, a professora traz uma série de questionamentos que permitem a construção de interpretações coletivas sobre a realidade a partir do vivido no jogo, dentre essas perguntas, destacamos duas que explicitam para a turma que o raciocínio construído a partir das oito questões deve ser utilizado para compreensão de um fenômeno real:

166. Professora: Não.... mas fora do jogo... pensa lá... se fosse lá... no meio

do mato... o tapiti... um de sete... um foi lá e comeu a planta... SEI ficaram sem comer... que que ia acontecer com esse tapiti?

179. Professora: Sim... mas assim... pensando no bichinho de verdade... por que será que aumenta o número de tapiti quando ele se alimenta?

Com essas perguntas, a professora indica uma condição relevante para a condução da investigação, o que acontece de forma similar no turno 164, quando ela mapeia para os estudantes quais das informações debatidas ao longo da aula devem ser consideradas para responder o problema apresentado, dizendo "esquece a jaguatirica por enquanto...", ou seja, para pensar nas consequências da extinção de plantas sobre a população de tapitis, é melhor que a turma se centre, apenas, nessas duas espécies. Em outros turnos, percebemos outras operações semelhantes da professora que visam ao mapeamento de condições relevantes presentes em suas perguntas e que associamos à prática de planejar e executar uma investigação, como nos turnos 160 e 162, quando ela destaca que os estudantes precisam pensar um cenário no qual "num ficasse nenhuma planta... e ainda ficassem sete tapitis... [...] mas antes da: da jaguatirica pegar os tapitis...”.

Essas condições são acolhidas pela turma e as respostas apresentadas passam a considerar o contexto externo ao jogo, evidenciando a constituição da norma de receptividade à crítica. Existe, contudo, uma possível exceção a essa norma na resposta de Fabrício apresentada no turno 178 que, inaudível para nós, parece remeter ao pega-pega e leva a professora a reafirmar que é preciso pensar nos animais e não nos personagens do jogo. Ao 
repetir aspectos a serem considerados para resolução do problema, a professora ajuda o grupo a estabelecer seus padrões públicos de análise.

Por meio das perguntas da professora e das hipóteses e justificativas apresentadas pelos estudantes, além da construção de explicações, temos a construção de um modelo explicativo para o fenômeno das populações estudado com os dados do jogo. Esse modelo articula as relações entre as populações de presa e de predador.

"Se não sobrasse nenhuma planta... e ainda ficassem sete tapitis..." "chegou o primeiro tapiti lá e comeu a planta... ainda ficaram SEI tapitis sem comer planta... [...] acabou a planta" (turnos 160 e 164) $\rightarrow$ "Ele [o tapiti] ia morrer porque ele não ia ter o que comer" (turnos 167 e 171) $\rightarrow$ "E se o tapiti morresse" "a jaguatirica fica sem comer e morre" (turnos 172 e 173)

"Quando os tapitis comiam a planta... aumentava o número de tapitis" [porque] "eles iam engordar mais..." "ele fica forte... aí a tapiti fêmea vai lá... namora o tapiti macho" "aí tem filhote" (turnos 176, 177, 181 e 182)

Figura 13 - Modelo construído durante a resolução dos problemas propostos na Aula 8 - Análise dos dados da tabela

Conforme o NRC (2011), os modelos são representações, de certa forma, análogas aos fenômenos que representam, permitindo aos cientistas melhor visualizar e entender um fenômeno sob investigação, formular perguntas e explicações, comunicar ideias a outros membros das comunidades científicas ou desenvolver uma possível solução para um problema. Na aula em análise, a construção de um modelo explicativo permite ao grupo entender um fenômeno que vem sendo estudado desde a aula anterior e que será sistematizado na aula seguinte: o equilíbrio entre espécies dentro de uma cadeia alimentar.

Nesse processo de construção de um modelo, consideramos que a igualdade moderada está constituída na sala e todos são reconhecidos e se reconhecem como capazes de contribuir. Essa norma se evidencia tanto na participação espontânea de estudantes, quanto na solicitação de contribuições pela professora que reconhece as hipóteses apresentadas pelo grupo como válidas e as aproveita para o desenvolvimento e articulação das ideias.

5.3.4 A leitura e discussão do texto "Entendendo o jogo presa e predador" e o registro individual das atividades 
Encerrada a análise dos dados da tabela, a professora distribui um texto de sistematização (anexo G) para turma, no qual são relembradas as regras do jogo e é mencionada a necessidade de alimento como uma das condições para a sobrevivência de um ser vivo. No início desse momento, a professora propõe que a leitura do texto seja feita pelos estudantes que se oferecem para tanto, todavia, em decorrência das conversas paralelas e da altura da voz dos leitores, partes do texto são incompreensíveis e vemos alguns estudantes se queixando por não compreender o que é dito por seus colegas. Frente a essa situação, a professora encerra a leitura coletiva e passa a realizar a leitura em voz alta, aproveitando esse momento para trazer algumas explicações sobre o apresentado no texto.

Após a leitura, a professora faz alguns questionamentos que exigem dos estudantes a comunicação de informações lidas (turno 222 e 231), adotando uma dinâmica similar à vista na quinta aula, na qual as respostas dadas pelos estudantes são aceitas sem solicitação de detalhamento ou justificativas que permitam a conversão da descrição de uma situação em uma explicação.

Considerando que a discussão do texto fora concluída, a professora solicita à turma $\mathrm{o}$ registro da atividade em um desenho na ficha de questões e explica (turno 239) para os estudantes que não participaram da aula anterior que "tapiti é um coelho e a jaguatirica é uma onça”. Após receberem essas instruções, os estudantes trabalham por alguns instantes e não podemos compreender mais que alguns fragmentos de suas conversas.

Concluindo a atividade, a professora diz que a aula seguinte será o encerramento do "Projeto de experimentação científica" naquele ano e que, por esse motivo, os estudantes não devem faltar.

5.3.5 Considerações sobre a atividade "Análise dos dados da tabela"

Como síntese do discutido acima, o quadro 33 apresenta operações que evidenciaram as quatro normas para construção de explicações científicas para os problemas propostos, construídas a partir de Longino (2002), e de SEI das oito práticas das comunidades científicas nas quais os estudantes de ciências devem ser iniciados, conforme NRC (2011). Essas operações evidenciadas durante a aula no ajudarão, ao final deste trabalho, a caracterizar 
normas e práticas culturais que são produzidas no espaço de sala de aula de ciências organizado pelo ensino por investigação.

\begin{tabular}{l}
\hline \multicolumn{1}{c}{ NORMAS CULTURAIS DO ENSINO DE CIÊNCIAS POR INVESTIGAÇÃO } \\
\hline Fórum \\
- Estudantes apresentam/ justificam hipóteses \\
$-\quad$ Professora apresenta/critica/repete hipóteses/planos de trabalho/ métodos de investigação
\end{tabular}

\section{Receptividade à crítica}

- Estudantes apresentam hipóteses desconsiderando críticas

- Estudantes apresentam/ revisam hipóteses considerando críticas

\section{Padrões públicos de análise}

- Professora apresenta critérios para análise de hipótesess

\section{Igualdade Moderada}

- Estudantes apresentam contribuições

- Professora solicita/ interrompe/ rejeita contribuições

- Professora chama atenção de estudantes

\section{PRÁTICAS CULTURAIS DO ENSINO DE CIÊNCIAS POR INVESTIGAÇÃO}

\section{Fazer perguntas}

- Estudantes fazem perguntas para testar hipóteses

- Estudantes fazem perguntas sobre métodos de investigação

- Professora apresenta problema

- Professora faz perguntas para guiar a construção de explicações

\section{Desenvolver e utilizar modelos}

- Estudantes apresentam interpretações baseadas no jogo

- Professora solicita interpretações baseadas no jogo

- Professora articula interpretações para desenvolvimento de um modelo

\section{Planejar e executar investigações}

- Professora apresenta métodos de investigação

- Professora mapeia condições relevantes

- Professora solicita que estudantes peguem materiais

\section{Analisar e interpretar dados}

- Estudantes analisam/ solicitam ajuda analisar para dados

- Professora apresenta ferramentas para organizar dados

- Professora indica como analisar dados

\section{Utilizar pensamento matemático e ferramentas computacionais}

- Estudantes apresentam/ justificam hipóteses utilizando pensamento matemático

- Estudantes solicitam ajuda para utilizar pensamento matemático

- Professora solicita que estudantes apresentem/ justifiquem hipóteses utilizando pensamento matemático 
- Professora indica como utilizar pensamento matemático

\section{Construir explicações}

- Estudantes apresentam hipóteses/ justificativas coerentes

- Estudantes apresentam hipóteses incoerentes

- Professora solicita que estudantes apresentem/ justifiquem hipóteses

- Professora indica inconsistências em hipóteses

\section{Engajar-se em argumentações baseadas em evidências}

\section{Obter, avaliar e comunicar informações}

- Estudantes comunicam informações

- Professora lê/ destaca informações de textos

- Professora solicita que estudantes comuniquem informações

Quadro 33 - Síntese das normas e práticas presentes na Aula 8 - Análise dos dados da tabela

Começando pelas considerações sobre as normas, percebemos que a apresentação, crítica e justificativa de hipóteses, planos de trabalho e métodos de investigação estão presentes nessa aula e evidenciam a constituição da norma de fórum. Destacamos nessa norma, a frequência com que encontramos a apresentação do plano de trabalho, nas orientações da professora para que os estudantes trabalhem juntos e para que utilizem a tabela, mas principalmente, a insistência da professora em apresentar um método de investigação, indicando para os grupos como a leitura dos dados pode ser feita. Essas duas operações em conjunto são aqui interpretadas como um esforço, por parte da professora, para que os estudantes compreendessem a função da tabela e a adotassem o repertório disponibilizado para a resolução dos problemas.

Sobre a receptividade à crítica e os padrões públicos de análise, podemos fazer destaque similar, pois identificamos operações relacionadas a essas normas, tanto no movimento de crítica e revisão de hipóteses, quanto no de apresentação e adoção de um método de investigação. Nesse sentido, tanto a professora apresentou critérios para análise de novas ideias, revelando para turma aspectos de interpretação dos enunciados e compreensão dos problemas, quanto estabeleceu com eles maneiras mais adequadas para realização da leitura dos dados organizados na tabela. Os critérios indicados pela professora em ambos contextos foram adotados pelos grupos para construção e posterior partilha das hipóteses.

Como última norma, considerando que a igualdade moderada se constitui em sala quando as possibilidades de participação são relativizadas por níveis de expertise ou conhecimento, de modo que todos sejam considerados igualmente capazes de contribuir, podemos afirmar que esta norma esteve presente durante a aula, evidenciando-se nas 
solicitações e apresentações de contribuições. Importante ressaltar que a rejeição de contribuições também tem ocorrências nessa aula, sendo, todavia, acompanhada de perguntas ou outras intervenções da professora a fim de conduzir a construção de explicações justificadas paras os problemas apresentados.

Ainda sobre essa norma, como discutido nas outras aulas analisadas, identificamos passagens pontuais, seja em momentos em que a professora quer destacar hipóteses durante a partilha de resultados, seja durante a leitura do texto ou apresentação do plano de trabalho, em que a professora chama a atenção de alguns estudantes, a fim de manter a disciplina na sala. Nesses momentos, compreendemos que a igualdade é moderada por uma relação vertical de autoridade.

Passando para discussão das práticas, percebemos que nessa aula, como na primeira aula analisada, o fazer perguntas e o construir explicações encontram-se bastante articulados nos turnos da professora de modo que, além da apresentação dos oito problemas propostos para essa atividade, encontramos com frequência a formulação de perguntas que guiam a construção de explicações, seja solicitando maior detalhamento das ideias, seja solicitando uma justificativa baseada nos dados da tabela. Nos turnos dos estudantes, a prática de fazer perguntas se evidencia tanto em dúvidas formuladas com relação à realização da ferramenta, quanto no teste de hipóteses.

Como segunda prática apresentada em nosso quadro síntese, temos o desenvolvimento e utilização de modelos que ainda não aparecera na análise das demais atividades e que aqui se evidencia tanto pela apresentação de interpretações baseadas no jogo por parte dos estudantes, quanto pela solicitação e articulação de interpretações para desenvolvimento de um modelo, por parte da professora. Conforme o NRC (2011), os estudantes podem iniciar a aproximação com os modelos pela realização de registros do observado, progredindo para construção de modelos abstratos que sirvam como ferramentas para elaboração de previsões, como é visto na aula analisada conforme a turma parte dos padrões observado nos dados coletados durante o jogo e das relações estabelecidas entre esses, para formulação de previsões sobre situações de extinção.

Dentre as operações que evidenciam a prática de planejar e executar investigações, temos a apresentação do método de investigação pela professora o que, como já discutido nesta seção, é interpretado como uma etapa necessária de construção de bases para futuras investigações nas quais os estudantes tenham maior liberdade para propor seus desenhos de pesquisa. Ressaltamos, todavia, que esse plano não é imposto, mas conjuntamente construído à medida em que a professora passa pelos grupos indicando como os dados podem ser 
analisados e, a partir das instruções recebidas, os estudantes seguem trabalhando com seus colegas apresentando a avaliando hipóteses sustentadas nos dados organizados.

Esse foco no trabalho com a tabela permitiu a experiência com a prática de analisar $e$ interpretar dados que só havia aparecido de forma pontual na primeira aula. Nas comunidades científicas, essa prática se estabelece, pois a observação e as investigações científicas produzem um grande volume de materiais que precisam ser organizados em planilhas, tabelas, gráficos, entre outras ferramentas, para, então, poderem ser analisados. $\mathrm{Na}$ atividade proposta na SEI, o material coletado durante o jogo já é apresentado de maneira organizada para turma que precisa compreender como analisá-lo e, nesse processo, são importantes as operações da professora que apresenta a tabela para turma e indica como essa deve ser utilizada, mas também as operações dos estudantes que assumem essa ferramenta e analisam e interpretam os dados coletados durante o jogo.

Durante a análise e interpretação de dados, a prática de utilizar pensamento matemático também se evidencia, seja nos momentos em que a professora explica como os dados estão dispostos nas linhas e colunas, seja quando os estudantes pedem ajuda para comparar os valores registrados na tabela e estabelecer relações entre esses, seja quando a professora solicita que as hipóteses sejam apresentadas e justificadas a partir do repertório da matemática, ou seja, quando os estudantes assumem esse repertório e o utilizam na apresentação, justificativa e revisão de hipóteses. Com ou seu apoio do repertório da matemática, a prática de construir explicações pode ser vista desde os trabalhos em pequenos grupos quando as primeiras hipóteses são propostas e debatidas até a partilha dos resultados quando, coletivamente, essas proposições são apresentadas e justificadas.

Por fim, a prática de obter, avaliar e informações, se evidencia durante a leitura do texto por operações que se relacionam à solicitação e comunicação de informações, mas não à avaliação ou interpretação do disposto no texto.

Durante o enfrentamento e a resolução dos problemas, observamos os estudantes conversando sobre as questões, apontando para lousa e para tabela que têm em mãos, indo à frente da sala para apresentar suas ideias, enfim, trabalhando de maneira colaborativa para construção de explicações. Essa troca é possibilitada, pois existe um ambiente em que todos podem e parecem se sentir capazes de contribuir, de interagir e de se apoiar na realização da atividade, o que identificamos como a presença de engajamento mútuo, um elemento necessário para caracterização das comunidades de práticas (WENGER, 2016).

Além do engajamento mútuo observado, para caracterização de um grupo como uma comunidade de práticas é necessário que exista identificação com o projeto, o que implica na 
negociação de formas de trabalhar de maneira coordenada a fim de realizar seus projetos da melhor forma possível. Essa negociação é proposta pela professora desde o início da aula e incentivada à medida em que ela pede que os alunos leiam os problemas e busquem os dados juntos, podendo ser observada, também, no trabalho com a tabela. Conforme Wenger (2016), o estabelecimento das ferramentas que devem ser adotadas e dos modos como utilizá-las, como visto na aula, também são entendidos como parte da constituição da identificação com o projeto.

Por fim, ainda sobre o uso da tabela, destacamos a partilha de um repertório, como elemento característico de uma comunidade de práticas. Desde o início da aula, os estudantes trabalham com a ferramenta recebida, manuseando-a e referindo-se a ela durante o enfrentamento e resolução do problema, o que evidencia não só a existência, mas a adoção de um bem do repertório da matemática. Como não temos disponíveis registro de outras aulas em que a turma tenha trabalhe com tabelas, não é possível afirmar se a ferramenta seguirá disponível no repertório do grupo e se será retomada em situações futuras, todavia, é perceptível que, ao longo da aula analisada, os estudantes mostram-se mais exitosos na realização da análise e interpretação dos dados.

\subsection{Considerações sobre a SEI "Navegação e Meio Ambiente"}

Após análise e discussão das três aulas, é possível apresentar algumas considerações gerais sobre os resultados obtidos. Iniciamos essas considerações com um quadro que sintetiza as maneiras como as quatro dimensões da prática profissional das comunidades científicas que devem compor os objetivos para o ensino de ciências (STROUPE, 2015) aparecem na proposição das atividades que compõem a SEI.

\begin{tabular}{ll}
\hline Dimensões... & \multicolumn{1}{c}{ integradas nos objetivos das atividades analisadas } \\
\hline Conceitual & $\begin{array}{l}\text { Construir coletivamente entendimento sobre conteúdos } \\
\text { Discutir conteúdos apresentados } \\
\text { Construir coletivamente explicações que serão, posteriormente, sistematizadas }\end{array}$ \\
\hline \multirow{3}{*}{ Social } & $\begin{array}{l}\text { Compreender, negociar e adotar normas de participação } \\
\text { Propor e participar de processos colaborativos de trabalho } \\
\text { Propor, discutir e partilhar hipóteses e procedimentos }\end{array}$
\end{tabular}


Propor, avaliar e rever hipóteses e procedimentos durante o enfrentamento de problemas

Epistêmica Partilhar resultados de maneira a comparar hipóteses e procedimentos

Participar de tomadas de decisões sobre o que deve ser considerado como uma explicação coerente

Representar os fenômenos estudados

Material Ler e discutir textos informativos e ilustrações

Analisar e interpretar dados organizados em tabela

Registrar procedimentos adotados e explicações construídas

Quadro 34 - Maneiras como as dimensões a serem integradas nos objetivos para o ensino de ciências aparecem nas atividades analisadas

Como visto ao longo da análise, no planejamento da SEI são sugeridas maneiras de trabalho que abrangem as quatro dimensões com maior ou menor enfoque, conforme os objetivos, procedimentos e exercícios de cada atividade. $\mathrm{Na}$ implementação desse planejamento em sala de aula, particularidades do grupo e os diferentes contextos conferiram especificidades ao trabalho, como evidenciado pela criação de ferramentas de trabalho não indicadas na SEI, pela adoção ou rejeição do repertório disponibilizado, pela negociação e estabelecimento das normas de partição, pelo envolvimento da turma na proposição, análise e revisão de hipóteses e procedimentos, enfim, pelas diferentes maneiras de fazer construídas pelo grupo em situações distintas.

Com relação à dimensão conceitual, nas quatro atividades analisadas temos a proposição ora de construção de entendimento sobre um princípio (atividade 1), ora de apresentação e discussão de um conceito (atividades 6 e 7), ora a construção coletiva de explicações que subsidiarão sistematizações futuras (atividade 9), mas nessas diferentes abordagens é constante a preocupação de trabalhar conceitos, teorias, princípios, leis e outros conteúdos que os estudantes precisam para construir, comunicar e apreciar explicações científicas para os problemas que lhes são propostos. Retomando os desafios para o Ensino de Ciências por Investigação elencados por Kelly (2014, p. 1364), compreendemos que essa preocupação está associada à premissa de que "os estudantes precisam de conceitos para aprender conceitos", ou seja, de que as propostas para o Ensino de Ciências por Investigação não devem sugerir que os estudantes induzam conceitos científicos sofisticados a partir da experimentação ou do contato com fenômenos empíricos, mas sim propor situações de trabalho com conteúdos que possibilitem que os estudantes se envolvem em atividades e discursos similares aos das comunidades científicas, permitindo assim novas aprendizagens. 
Pela síntese das orientações relacionadas à dimensão social, percebemos como constante nas quatro atividades analisadas a sugestão de normas de participação que, como visto na implementação da SEI, foram apresentadas pela professora e negociadas pelo grupo que ora adotou o sugerido (atividade 9), ora criou sobre ele (atividades 1, 6 e 7) mantendo, todavia, o processo colaborativo de trabalho indicado na SEI. Importante ressaltar, contudo, que nos momentos de leitura de texto (atividades 6, 7 e 9), embora tenhamos a participação de diversos estudantes, a partilha e revisão de hipóteses é menos evidente que nos demais momentos de trabalho coletivo o que reflete, também, na promoção da dimensão epistêmica.

Sobre essa dimensão, nas quatro atividades analisadas identificamos diretrizes para que sejam criados momentos de proposição, avaliação e revisão de hipóteses e procedimentos e de participação dos estudantes no estabelecimento de critérios e decisões sobre o que deve ser considerado como uma explicação para os problemas propostos. Esses momentos são evidenciados durante o entendimento dos problemas na primeira e na nona atividade, no trabalho em pequenos grupos de análise e interpretação de dados da tabela (atividade 9) e nas discussões coletivas para construção de explicações aos problemas propostos (atividade 1 e 9). Entretanto, nas atividades de discussão de textos (atividades 6, 7 e 9), a presença de avaliação e revisão de hipóteses é menos frequente e a construção de respostas para os problemas acabaram por seguir um caminho mais descritivo que explicativo.

Consideramos a partir das aulas analisadas que a presença das dimensões social e epistêmica nos objetivos, procedimentos e exercícios da SEI pode permitir a superação de outro desafio para o Ensino de Ciências por Investigação apresentado por Kelly (2014): ampliar o foco dos conhecimentos produzidos para a participação em práticas das comunidades científicas que envolvem a criticidade. Como discutido acima, a efetivação dessa possibilidade se dá conforme a implementação das atividades à medida em que a turma consegue criar oportunidades para experimentar essas práticas.

Por fim, a síntese da dimensão material indica o registro de procedimentos adotados e de explicações construídas ao final das atividades, como uma recomendação constante para as atividades. Além dessa, existem outras recomendações específicas relacionadas ao repertório disponibilizado para cada atividade, como a utilização de textos e informativos e a interpretação de ilustrações durante o processo investigativo (atividades 6 e 7) ou a adoção da tabela como ferramenta para resolução dos problemas (atividade 9). Observando também a implementação dessas atividades, podemos destacar outras maneiras de trabalhar essas dimensões, como a representação do fenômeno estudado (atividade 1) e os registros, 
anotações e cálculos que observamos os estudantes fazerem durante o enfrentamento e resolução dos problemas.

Encerradas nossas observações sobre o planejamento das atividades, passemos agora para apresentação de nossas considerações sobre as normas culturais do Ensino de Ciências por Investigação evidenciadas durante a implementação das atividades. Essas normas foram construídas e partilhadas pelo grupo e organizaram a participação nos processos coletivos de enfrentamento e resolução de problemas.

\section{NORMAS CULTURAIS DO ENSINO DE CIÊNCIAS POR INVESTIGAÇÃO}

\section{Fórum}

- Estudantes apresentam/ criticam/ revisam/ justificam hipóteses

- Professora apresenta/critica/repete hipóteses/planos de trabalho/ métodos de investigação

\section{Receptividade à crítica}

- Estudantes apresentam hipóteses desconsiderando críticas

- Estudantes apresentam/ revisam hipóteses considerando críticas

\section{Padrões públicos de análise}

- Estudantes retomam critérios já estabelecidos para análise de hipóteses

- Professora e estudantes retomam conhecimentos já estabelecidos para apresentação de novas ideias

- Professora apresenta critérios para análise de hipóteses

- Professora retoma critérios já estabelecidos para análise de hipóteses

\section{Igualdade Moderada}

- Estudantes apresentam/ solicitam/ rejeitam contribuições

- Estudantes solicitam autorização para falar

- Professora solicita/ interrompe/ ignora/ rejeita contribuições

- Professora chama atenção de estudantes

Quadro 35 - Síntese das normas presentas nas aulas analisadas

Nas seções anteriores, discutimos as maneiras como as quatro normas para construção de explicações científicas para os problemas propostos aparecem durante a realização das atividades analisadas. Essas normas foram definidas para este trabalho a partir do que Longino (2002) identifica como necessário para que ocorra o processo social de construção do conhecimento garantindo a ocorrência de interações discursivas críticas e, assim, resguardando a objetividade desse processo.

No contexto da sala de aula analisada, identificamos que a norma de fórum esteve vigente ao longo das três aulas, evidenciando-se pela apresentação de hipóteses, planos de trabalho e métodos de investigação. Já as operações que indicam a crítica, revisão e 
justificativa desses não são constantes nas três aulas, ocorrendo com maior frequência na primeira e na oitava em momentos de construção de entendimento sobre os problemas, de proposição de respostas e de validação das hipóteses levantadas, seja pela partilha das respostas construídas (aula 8), seja pela encenação do problema (aula 1). Ainda sobre essa norma, destacamos a repetição de hipóteses que aparece em turnos da professora quando essa busca compartilhar ou parafrasear algumas das ideias trazidas pelos estudantes identificadas como centrais para o desenvolvimento de explicações para os problemas propostos. Com essas operações, a professora ajuda a turma a caminhar junta para construção de explicações aos problemas apresentados.

Ainda sobre as normas, em nossa discussão dos episódios, a constituição de receptividade à crítica evidenciou-se articulada ao estabelecimento de padrões públicos de análise, uma vez que o aceite de críticas e a reflexão e revisão de ideias a partir dessas foram identificados em sequência da apresentação ou retomada de critérios e conhecimentos que organizavam e davam suporte à análise de novas ideias. Ou seja, hipóteses que consideravam as críticas ou que indicavam que as ideias não foram revisadas a partir das apreciações feitas aparecem nas aulas quando critérios para avaliar e rejeitar as respostas dadas por um estudante são apresentados ou retomados (aula 1 e 8), quando condições explícitas e implícitas no problema são apontadas (aula 1) ou quando é indicado para os grupos como as linhas e colunas da tabela podem ser lidas e interpretadas (aula 8). Ainda que essas operações para estabelecimento dos padrões públicos de análise se concentrem em turnos da professora, identificamos passagens em que os critérios de avaliação são retomados pela turma, como quando algum estudante aponta inconsistência nas respostas de seus colegas (aula 1) ou quando esses se auxiliam na utilização do repertório disponibilizado, conforme o estabelecido pelo grupo durante a aula (aula 1 e 8 ).

A norma de padrões públicos de análise também se evidencia na quinta e na oitava aula nos momentos em que a professora e os estudantes retomam conhecimentos já estabelecidos em aulas anteriores ou sistematizam explicações construídas durante a realização da atividade a fim de estabelecer critérios e conhecimentos que darão suporte a apresentação de novas ideias. Essas operações se fazem necessárias, pois as atividades da SEI estão articuladas entre si, de modo que conteúdos previamente trabalhados são importantes para o enfrentamento de problemas propostos a cada nova atividade.

Por fim, a norma de igualdade moderada está vigente nas três aulas, sendo que, na maior parte do tempo, a paridade entre os membros da sala é relativizada por níveis de expertise ou conhecimento, de modo que todos são considerados igualmente capazes de 
contribuir e apresentar suas ideias. Em alguns momentos específicos, como durante a leitura de textos (aulas 5 e 8) e a apresentação dos planos de trabalho e problemas (aulas 1, 5 e 8), identificamos que a igualdade é moderada por uma relação vertical de poder entre a professora e os estudantes, o que se evidencia pelas interrupções de turnos dos estudantes ou pelas advertências feitas a alguns estudantes. Interpretamos essas operações como maneiras encontradas pela professora para garantir que toda a turma acompanhe as atividades.

Seguindo com nossas considerações sobre a implementação das atividades, passemos agora para apresentação de nossas considerações sobre as práticas culturais do Ensino de Ciências por Investigação, compreendidas como as maneiras de fazer produzidas e partilhadas por um grupo de estudantes e sua professora a partir dos bens e mensagens disponibilizados na aula de ciências durante a realização de atividades de ensino investigativas.

Assim como as normas, essas práticas se evidenciam pelas operações culturais do Ensino de Ciências por Investigação, a ativação produtiva de práticas coletivas realizadas pela professora e pelos estudantes a partir das normas vigentes em sala.

PRÁTICAS CULTURAIS DO ENSINO DE CIÊNCIAS POR INVESTIGAÇÃO

\section{Fazer perguntas}

- Estudantes fazem perguntas para testar hipóteses

- Estudantes fazem perguntas sobre métodos de investigação

- Professora apresenta problema

- Professora faz perguntas para guiar a construção de explicações

- Professora faz perguntas para retomar o que já é conhecido

- Professora faz perguntas para testar hipóteses

\section{Desenvolver e utilizar modelos}

- Estudantes apresentam interpretações baseadas no jogo

- Professora solicita interpretações baseadas no jogo

- Professora articula interpretações para desenvolvimento de um modelo

\section{Planejar e executar investigações}

- Estudantes mapeiam condições relevantes

- Professora e estudantes identificam conhecimentos já estabelecidos pelo grupo

- Professora e estudantes conduzem e observam procedimentos para testar e desenvolver hipóteses

- Professora mapeia condições relevantes

- Professora apresenta métodos de investigação

- Professora propõe procedimentos para testar e desenvolver hipóteses

- Professora solicita que estudantes peguem materiais

\section{Analisar e interpretar dados}

- Estudantes analisam/ solicitam ajuda analisar para dados 
- Professora cria/ apresenta ferramentas para organizar dados

- Professora indica como analisar dados

\section{Utilizar pensamento matemático e ferramentas computacionais}

- Estudantes apresentam/ revisam/ justificam hipóteses utilizando repertório da matemática

- Estudantes solicitam ajuda para utilizar repertório da matemática

- Professora solicita que estudantes apresentem/ revisem/ justifiquem/testem hipóteses utilizando repertório da matemática

- Professora indica que problema deve ser respondido utilizando repertório da matemática/ como utilizar repertório da matemática

- Professora critica hipóteses utilizando repertório da matemática

\section{Construir explicações}

- Estudantes solicitam que outros estudantes apresentem hipóteses

- Estudantes apresentam hipóteses/ justificativas/ avaliações coerentes

- Estudantes apresentam hipóteses incoerentes

- Estudantes apresentam explicações já construídas

- Estudantes indicam inconsistências em hipóteses

- Professora solicita que estudantes apresentem/ revisem/ justifiquem/ avaliem hipóteses

- Professora solicita que estudantes apresentem explicações já construídas

- Professora apresenta explicações já construídas

- Professora indica inconsistências em hipóteses

\section{Engajar-se em argumentações baseadas em evidências}

- Estudantes avançam com/ defendem/ criticam hipóteses baseando-se em informações do problema

- Estudantes articulam argumentos em construção

- Professora solicita que estudantes avancem com/ defendam hipóteses baseando-se em informações do problema

\section{Obter, avaliar e comunicar informações}

- Estudantes comunicam/ interpretam informações

- Professora lê/ destaca informações de textos

- Professora solicta que estudantes comuniquem/ interpetem informações

Quadro 36 - Síntese das práticas presentas nas aulas analisadas

Iniciando nossas considerações sobre as práticas produzidas e partilhadas durante as aulas, podemos dizer que o fazer perguntas se evidenciou tanto em operações da professora, quanto dos estudantes. Nos turnos de fala da professora, essa prática esteve presente na leitura e interpretação dos problemas, nos momentos de revisão do que já era conhecido pelo grupo a partir de outras atividades e nas diversas maneiras de guiar o grupo na construção de novas respostas explicativas, ajudando-os a desenvolver, testar e justificar suas hipóteses. Nas operações dos estudantes, as perguntas estiveram presentes tanto como dúvida nos momentos 
em que pediam ajuda à professora ou a um colega, quanto como questionamentos sobre as hipóteses levantadas.

Como segunda prática, o desenvolvimento e uso de modelos aparece em uma única aula (aula 8) quando, após concluir a análise dos dados da tabela junto coma a turma, a professora solicita que os estudantes façam previsões sobre a dinâmica da cadeia alimentar estudada a partir de interpretações baseadas no jogo. Considerando a vivência dessa prática na aula, parece-nos pertinente destacar que o desenvolvimento do modelo, como visto no desenvolvimento de argumentos e explicações por essa sala, é conduzido pela professora por meio de questionamentos e da articulação de ideias. Interpretamos essa atuação da professora a partir da constatação de Sasseron e Duschl (2016) de que o professor exerce um papel central na constituição da sala como um espaço para a proposição, discussão e avaliação de ideias e na criação de oportunidades para que essas sejam utilizadas para construção de novos pontos de vista. Ou seja, a professora, ao conduzir e promover o debate de hipóteses, permite que sejam criadas condições para que o potencial investigativo da atividade seja realizado, nesse caso, pela vivência da prática de desenvolver modelos.

Pela análise da prática de planejar e executar investigações, percebemos que as diretrizes trazidas pela SEI oferecem um plano de trabalho, mas não condicionam os rumos da aula que são negociados pelo grupo quando, por exemplo, a professora propõe a encenação da situação apresentada no problema "A travessia do rio". Esse procedimento não estava presente nas orientações da SEI, mas acaba sendo central para ajudar a turma a testar e desenvolver hipóteses (aula 1).

A negociação e construção de planos de investigação também se dá à medida em que professora e estudantes mapeiam condições relevantes para construção de explicações para os problemas propostos, seja construindo sentido para o enunciado (aula 1), seja identificando informações centrais no texto para resolução dos problemas (aula 5), seja construindo maneiras de utilizar o repertório disponibilizado (aula 8). Outras operações que evidenciam essa prática, são identificadas nos momentos em que a turma retoma conhecimentos já estabelecidos pelo grupo, seja para seguir com a construção de uma explicação (aula 1), seja para enfrentar novos problemas a partir de conhecimentos já estabelecidos (aula 5 e 8) ou seja quando utilizam-se dos materiais disponíveis para propor, avaliar e revisar hipóteses, como ao adotarem a tabela como uma ferramenta de trabalho (aula 8) ou ao buscarem interpretar as ilustrações recebidas (aula 5).

Seguindo para a prática de analisar e interpretar dados, podemos falar de duas situações distintas nas quais ela se evidenciou. Na primeira aula analisada, a professora cria 
uma ferramenta (lista de ideias) para organizar alguns dados implícitos e explícitos no problema a fim de ajudar os grupos no processo de enfrentamento e resolução desse. Todavia, os estudantes não utilizam a lista escrita na lousa para apresentar suas hipóteses e o entendimento do problema é construído pelo estabelecimento de alguns critérios de análise reafirmados oralmente, de modo que a lista não foi adotada pela turma como uma ferramenta para análise e interpretação dos dados. Já na oitava aula, como orientado na SEI, a professora apresenta a tabela como uma ferramenta que fora utilizada para organização dos dados antes do início da atividade e que pode ser empregada para retomar informações e para construir explicações, mesmo pelos estudantes que não participaram da geração e coleta dos dados. Nessa aula, a ferramenta é adotada e a análise e interpretação dos dados é feita pelos estudantes evidenciando-se em operações da professora que solicita e auxilia a interpretação dos dados na tabela e dos estudantes que localizam e relacionam informações contidas em suas linhas e colunas.

Ainda na primeira e na oitava aula, temos evidências da prática de utilizar pensamento matemático, entretanto, nas atividades da SEI escolhidas para análise não há oportunidades para o uso de ferramentas computacionais. Nas operações que evidenciam essa prática, temos tanto a função comunicativa, à medida em que a professora indica para os estudantes como apresentar e justificar as respostas utilizando-se da nomenclatura adequada (aula 8), quanto a função estrutural quando, por exemplo, os estudantes podem trabalhar com a dedução lógica a partir dos dados do problema (aula 1) ou explorar a tabela a fim de responder questionamentos sobre um jogo (aula 8), servindo-se do repertório da matemática para apresentar, revisar e justificar hipóteses. A vivência de situações nas quais essas duas funções são exploradas é sugerida pelo NRC (2011) a fim de que os estudantes percebam e experimentem o papel da matemática no trabalho das comunidades científicas.

A próxima prática discutida, construir explicações, é esperada e ocorre nas três aulas, entretanto caracterizamos essa prática de maneiras distintas, conforme a condução da atividade. Como primeira maneira de construir explicações (aulas 1 e 8), identificamos a apresentação de hipóteses coerentes ou incoerentes pelos estudantes seguida de intervenções da professora a fim de apresentar inconsistências nas ideias trazidas ou de solicitar o desenvolvimento, avaliação ou revisão das hipóteses, aproveitando-as como ponto de partida para construção de explicações justificadas. Como segunda maneira observada, durante a leitura e discussão de textos (aulas 5 e 8), as hipóteses são acolhidas ou rejeitas sem a solicitação de análise e revisão, levando à construção de explicações mais descritivas dos fenômenos estudados. 
Pelo uso dos mapas de episódio para análise das operações que evidenciam as oito práticas, pudemos identificar que os momentos em que a construção de explicações se caracteriza pela apresentação, mas também pela revisão, avaliação e justificativa de hipóteses (primeira maneira), temos mais evidências da prática de fazer perguntas, em específico da operação de fazer perguntas para guiar a construção de explicações, e da prática de planejar e executar investigações pelo mapeamento de condições relevantes pela professora. Frente a essa constatação, acreditamos poder reafirmar o papel central da professora para criação de oportunidades para realização do potencial investigativo da SEI e para que práticas culturais similares às das comunidades científicas sejam produzidas e partilhadas em sala.

Ainda sobre a prática de construir explicações, pudemos perceber ao longo da análise que, nas aulas em que as explicações são mais exploradas e trabalhadas coletivamente, não só a professora, mas também os estudantes indicam inconsistências em hipóteses apresentadas e solicitam que colegas apresentem suas colaborações. Em um desses momentos de envolvimento dos estudantes com a comparação, avaliação e justificativa de hipóteses para construção de explicações (aula 1), identificamos o estabelecimento da prática de engajar-se em argumentações, ainda que não baseadas em evidências, mas nas informações do problema. Como operações que caracterizam essa prática, temos a solicitação, por parte da professora, e a apresentação de hipóteses justificadas, por parte dos estudantes, a fim de defender uma explicação que é construída coletivamente pela turma.

Por fim, a prática de obter, avaliar e comunicar informações é vivenciada durante as leituras e discussões de textos indicados na SEI, tendo se caracterizado mais pela localização e comunicação de informações do que pela avaliação ou construção de interpretações a partir dessas. Segundo orientações no NRC (2001), nas aulas de ciências os estudantes devem ter oportunidades de ler e produzir textos específicos de gêneros intrínsecos às ciências, o que é sugerido nas atividades dessa SEI, tanto pela indicação de que os estudantes façam registros que relatem as relações existentes entre as ações realizadas durante as atividades e os fenômenos investigados (aula 1, 5 e 8), quanto pela proposição de textos informativos que apresentam vocabulário específico e de ilustrações com indicação de escala, nomes científicos ou outros recursos do repertório das ciências (aulas 5 e 8).

A avaliação e debate das informações veiculadas nos materiais entregues aos estudantes são, potencialmente, promovidos pela interpretação de textos durante a leitura e pela resolução dos problemas a partir do lido. Contudo, não observamos a plena realização desse potencial durante a implementação das atividades analisadas, o que consideramos ser consequência da maneira como a prática de construir explicações se caracterizou durante as 
leituras de textos. Como já comentada acima, durante a realização das leitura e discussão de textos (aula 5 e 8), a professora formula poucas questões que levem os estudantes a analisar e revisar suas ideias e, assim, as hipóteses apresentadas não são aproveitadas para construção de explicações justificadas e a aula acaba por se centrar na comunicação, mas não na discussão, do que fora lido.

$\mathrm{Na}$ ativação dessas práticas, alguns materiais proporcionados pela SEI foram utilizados pelos estudantes e por sua professora, o que nos permite dizer que existiu a apropriação do repertório do Ensino de Ciências por Investigação, compreendido como o conjunto de bens e mensagens que são disponibilizados a estudantes e professores para implementação de atividades de ensino de ciências investigativas. No caso das atividades analisadas, como bens desse repertório, podemos listar a tabela, os textos informativos ou as ilustrações, e como suas mensagens, aquilo que é intangível no repertório, podemos falar das teorias científicas, dos procedimentos de análise de dados, do raciocínio lógico, dos processos argumentativos ou da linguagem matemática. 


\section{Considerações finais}

Iniciamos nossas considerações finais retomando algumas questões que, como apresentado em nossa introdução, foram definidas durante o planejamento e execução desta tese e nos ajudaram a responder nosso problema de pesquisa: quais normas e práticas culturais são produzidas no espaço de sala de aula de ciências organizado pelo ensino por investigação?

Para responder à nossa primeira questão, "o que é cultura e o que são as normas e a práticas culturais?", iniciamos a primeira seção deste trabalho com algumas discussões sobre o intrincado processo de (re)construção da palavra cultura, afirmada por Williams (2007) e Eagleton (2005) como um dos vocábulos mais complexos da língua inglesa. Com esse fim, buscamos traçar um breve percurso da construção histórica de significados em torno do conceito de cultura, perpassando as ideias de cultura como conceito hierárquico, diferencial e genérico (BAUMAN, 2012). Ainda nesse momento inicial, buscamos definir nosso lugar de partida no interior do debate posto, buscando ressaltar a fertilidade para análise resultante dos múltiplos significados que se encerram sob o termo e respeitando, assim, sua polissemia (VIDAL, 2006). Para tanto, trouxemos os estudos de Bauman (2012) e de Certeau (1985, 2014), apontando o que cada um desses autores nos oferece como contribuição para pensar a cultura na tensão entre permanência e mudança.

A fim de construir subsídios para análise das normas e práticas culturais, aproximamo-nos da ideia de cultura como "uma matriz de permutações possíveis, finitas em escolhas, mas incontáveis na prática" (BAUMAN, 2012, p. 40). Para compreender essa ideia, buscamos a linguagem matemática na qual uma matriz de permutação é aquela que tem o efeito de gerar uma permutação dos elementos de um vetor ou entre linhas ou colunas de outra matriz. Nessa operação os elementos da matriz se rearranjam dando forma a uma nova combinação. Em um paralelo com a linguagem matemática e a partir do que propõe Bauman (2012), podemos falar que a cultura, como uma matriz de permutações, se aplica sobre os repertórios disponibilizados aos sujeitos em determinados circuitos culturais e, com isso, rearranja de incontáveis formas os bens e mensagens que o compõem, dando forma a novas maneiras de compreender e agir sobre a realidade.

Esse (re)emprego por parte dos praticantes não se dá de forma aleatória, mas regido por uma lógica interna de modo que, “como na literatura se podem evidenciar 'estilos' ou maneiras de escrever, também se podem distinguir 'maneiras de fazer' - de caminhar, ler, 
produzir, falar etc." (CERTEAU, 2014, p. 87) ou, para esta pesquisa, maneiras de compreender e de agir sobre a realidade partilhadas por uma professora e estudantes de um $3^{\circ}$ ano de uma EMEF durante a implementação de uma SEI.

A partir desse referencial, aproximamo-nos de alguns autores que discutem o processo de construção do conhecimento como uma prática social regida por normas próprias. No interior desse debate, Longino (2002) propõe um conjunto de quatro normas sociais que devem organizar o processo de construção de conhecimento científico: fórum, padrões públicos de análise, receptividade à crítica e igualdade moderada. Essas normas organizam processos críticos e objetivos de construção de conhecimento científico e são tanto resultantes de práticas estabelecidas e já legitimadas nas comunidades científicas, quanto norteadoras das maneiras de agir no interior dessas comunidades. Conforme Kelly e Licona (2018), essas maneiras de agir socialmente construídas e ativadas nas interações sociais podem ser padronizadas ao longo do tempo, se estabelecendo com práticas entre os membros de um grupo.

Discussões como as apontadas acima, "colocam em evidência a ciência como uma cultura, com normas e práticas a partir e por meio das quais se desenvolve" (SASSERON; DUSCHL, 2016, p. 56) e implicam em propostas para o ensino de ciências que passam a advogar a importâncias de os estudantes de ciências se aproximarem das práticas das comunidades científicas, vivenciando processos de construção de conhecimento similares aos utilizados pelos membros dessas comunidades (DUSCHL, 2008; STROUPE, 2015; FORD, 2015). No conjunto de nossos dados buscamos, justamente, identificar e caracterizar quais práticas são vivenciadas pelo grupo de estudantes do $3^{\circ}$ ano e sua professora, no processo de construção de explicações para os problemas enfrentados em sala. bem como, pela análise das regras que organizam suas maneiras de fazer, identificar e caracterizar as normas vigentes em sala.

Antes de tratarmos da análise dos dados, apresentamos algumas considerações sobre a nossa segunda questão intermediária: como as normas e as práticas culturais estão presentes e podem ser analisadas no contexto de sala de aula?. Para responder a essa questão, trouxemos algumas reflexões sobre as problemáticas teórico-metodológicas associadas a um estudo que se debruce sobre as práticas escolares, colocando a ação dos sujeitos, sob a perspectiva da mudança e da permanência, como centro da investigação (VIDAL, 2006). Nesse sentido, para análise das normas e práticas no contexto de sala de aula, foi preciso ter em conta que as práticas escolares se constituem como práticas culturais, o que significa dizer que elas "apresentam modos de estar no mundo, de compreender a realidade e 
de estabelecer sentido, partilhados social e historicamente" (VIDAL, 2006, p. 158) não sendo, portanto, individuais, ainda que ativadas individualmente. Isso implica considerar que as operações identificadas nos turnos dos estudantes evidenciam práticas daquela sala, construídas e partilhadas pelo grupo, podendo ser analisadas como uma produção coletiva e não como um traço individual.

Como segunda problemática, foi importante considerar "que a característica mesma das práticas é ser praticada" (VIDAL, 2006, p. 158), de modo que sua caracterização não poderia se dar pela análise única de documentos ou de prescrições, mas sim das interações vividas em sala de aula. Essa questão norteou nosso desenho de pesquisa e justifica o esforço de analisar, conjuntamente, planejamento e implementação das aulas.

Em terceiro lugar, era preciso ter em conta que as práticas "se revelam nos usos dados ao conjunto de objetos culturais com os quais convivem" (VIDAL, 2006, p. 159), de modo que a existência de um repertório em sala não implica em seu uso, em sua apropriação pelo grupo como repertório a ser empregado em suas operações, como pôde ser visto na análise da primeira aula, quando professora cria uma ferramenta (lista de ideias) que não é adotada pela turma, mas também ao longo das leituras de textos e imagens, quando os estudantes, ainda que em posse desses bens, não parecem analisa-los ou retornar a eles para responder aos problemas encontrados. Diferentemente do que é visto na oitava aula, com o uso da tabela.

Importante também relembrar que as práticas culturais são híbridas, surgem da criatividade individual e coletiva no uso dos repertórios de diferentes contextos culturais aos quase os sujeitos estão expostos. Ou seja, são apropriações e transformações das diversas culturas que convivem no interior da escola, não podendo ser definidas como puras ou próprias de uma cultura específica. Nesse sentido, as práticas em análise neste trabalho, não são práticas da cultura científica, mas a ativação de uma mescla de culturas, como as culturas familiares, infantis, docentes, administrativas que estão presentas na escola marcadas pela inventividade dos sujeitos e pelas normas que organizam aquele grupo.

Consideradas essas problemáticas, partimos para nosso terceiro questionamento intermediário: no planejamento de atividades investigativas são pensadas situações que oportunizem a produção de normas e práticas em sala de aula?. O que respondemos, parcialmente, a partir das discussões teóricas apresentadas da terceira seção que podem ser resumidas na afirmação de Zômpero e Laburú (2011) de que as diferentes abordagens para o Ensino de Ciências por Investigação preconizam a relevância de as atividades investigativas serem compostas de um problema a ser analisado e de essas serem organizadas de modo a 
promover o trabalho com hipóteses e a realização de processos investigativos visando à obtenção de informações, a interpretação dessas e a posterior comunicação das explicações construídas, de modo que podemos afirmar que, no planejamento das atividades investigativas é previsto que, nas aulas de ciência, sejam vivenciadas práticas similares àquelas realizadas pelos membros de comunidades científicas no processo de construção de conhecimento.

$\mathrm{Na}$ etapa empírica de construção de uma resposta para nosso terceiro questionamento, buscamos identificar se no planejamento da SEI "Navegação e Meio Ambiente" existem orientações que remetem às quatro dimensões integradas da prática profissional das comunidades científicas: dimensão conceitual, dimensão social, dimensão epistêmica e dimensão material (STROPUE, 2015). Segundo Stroupe (2015), essas quatro dimensões devem integrar os objetivos para o ensino de ciências a fim de que sejam criadas oportunidades para que professor e estudantes reconstruam e aprofundem suas ideias e explicações sobre o mundo natural, enquanto se engajam em processos simplificados de trabalho científico.

A partir da análise dos objetivos gerais da SEI "Navegação e Meio Ambiente" e do planejamento de quatro das atividades que a compõem, pudemos perceber que na proposição das atividades da sequência são harmonizados objetivos de ensino conceituais, epistêmicos, sociais e materiais. O trabalho com essas quatro dimensões é sugerido, por exemplo, ao orientar-se que perguntas, suposições, dados e conclusões sobre os problemas propostos sejam comunicados, respeitando-se diferentes opiniões e utilizando-se de justificativas; que os textos informativos disponibilizados aos estudantes sejam utilizados como fonte de informações; que as informações e dados coletados sejam organizados e registrados por meio de desenhos e pequenos textos e que as ferramentas proporcionadas sejam exploradas com auxílio do professor. Desse modo, podemos afirmar que essa sequência, potencialmente, cria oportunidades para que os estudantes vivenciem diferentes práticas similares às das comunidades científicas. Se durante a implementação da SEI esse potencial for efetivado, é possível que a sala de aula se configure como comunidades de práticas na qual professor e estudantes negociem formas de participação no processo de construção de explicações (DUSCHL, 2008; STROUPE, 2014).

Dessa possibilidade, surge a hipótese de que a sala de aula analisada poderia configurar-se como uma comunidade de práticas, durante o enfrentamento dos problemas propostos na SEI. Para sustentar a discussão sobre as comunidades de práticas cientificas no contexto escolar, trouxemos a definição de que uma comunidade de práticas é caracterizada pelo engajamento mútuo, compreendido como a garantia de livre interação entre seus 
membros de modo que todos possam apresentar sus ideias de se apoiar na realização de suas atividades; pela identificação com um mesmo empreendimento alcançada à media em que os membros de uma comunidade negociam formas de trabalhar de maneira coordenada a fim de realizar seus projetos da melhor forma possível, de modo que os projetos nunca sejam, totalmente, determinados por agentes ou fatores externos; e pela e a partilha de um repertório construído conforme os membros de uma comunidade se engajam na realização de projetos e criam ou adotam rotinas, palavras, gestos, aparelhos ou outros signos e ferramentas que os auxiliam na negociação de sentidos e na execução de seu trabalho (LAVE; WENGER, 1991; WENGER; SNYDER, 2001; WENGER, 2016).

Assumida essa definição, defendemos a hipótese de que a sala de aula analisada se constituiu como uma comunidade de práticas, uma vez que encontramos, em cada uma das aulas, evidências de engajamento mútuo tanto pela organização da sala como um espaço no qual todos puderam contribuir e se apoiar durante o enfrentamento e resolução dos problemas, quanto pela garantia de livre interação e participação entre os estudantes e entre esses e sua professora, ainda que respeitadas as relações hierárquicas. Também consideramos que, durante a realização das atividades, houve identificação da sala com o projeto, como podemos ver pela negociação de sentidos durante a interpretação dos problemas de modo que as atividades e seus caminhos de realização não foram, totalmente, determinados pelo planejamento da SEI e, também, pelo estabelecimento de normas de participação nos debates e de critérios para definir aquilo que seria relevante para o grupo durante a realização das atividades, de que ideias poderiam ser tomadas como pressupostos e de que ferramentas deveriam ser adotadas ou descartadas. Por fim, podemos falar que houve partilha de um repertório disponibilizado pela SEI, uma vez que bens, como a tabela, e mensagens, como a linguagem matemática, foram adotados pelo grupo como auxiliares na negociação de sentidos e na realização de seus projetos.

Por fim, passemos para as considerações finais sobre a pergunta de pesquisa que guiou essa investigação: Como se caracterizam normas e práticas culturais que são produzidas no espaço de sala de aula de ciências organizado pelo ensino por investigação?

Iniciando pelas considerações sobre as normas culturais do Ensino de Ciências por Investigação, recapitulamos o conjunto de normas que, conforme Longino (2002), são necessárias para a promoção de interações discursivas críticas entre os membros de comunidades científicas a fim de que, no processo de construção de conhecimento, não sejam empregues elementos subjetivos de interpretação. Para a autora, a presença de fóruns, padrões públicos de análise, receptividade a crítica e igualdade moderada promove interações críticas 
que ajudam a transformar o subjetivo em objetivo ao assegurar que "o que é ratificado como o conhecimento sobreviveu à crítica de múltiplos pontos de vista (LONGINO, 2002, p. 129).

Segundo Kelly (2014), essas quatro normas, podem ser adaptadas para o contexto escolar, fazendo-se necessária a investigação de como elas se constituem em sala de aula. Partilhando dessa ideia, neste trabalho, a partir do apresentado por Longino (2002), propusemos que para constituição de comunidades de práticas científicas no contexto escolar, nas quais houvesse efetiva participação de alunos e professor no processo de construção e avaliação de explicações, seria necessária a configuração da sala de aula como um espaço de apresentação, crítica e revisão de evidências, métodos, hipóteses, argumentos, entre outros (fórum); a aceitação de críticas e a reflexão e revisão de ideias a partir dessas (receptividade à crítica); o estabelecimento, com o grupo, de um conjunto de critérios e conhecimentos que organizem e deem suporte à análise de novas ideias (padrões públicos de análise) e a constituição de igualdade de participação entre os membros de uma sala de aula, relativizada por níveis de expertise ou conhecimento, mas não por uma relação vertical de poder entre professor e estudantes, de modo que todos sejam considerados igualmente capazes de contribuir (igualdade moderada). Essas quatro normas adaptadas serviram como uma de nossas ferramentas para análise da implementação de quatro atividades que compõem aa SEI "Navegação e Meio Ambiente", a fim de identificar e caracterizar as normas que regem o processo de construção de explicações para os problemas propostos a cada atividade.

No processo de análise das aulas, identificamos momentos bastante distintos em sala e que, de modo geral, nos permitem dizer que, no início das aulas, a apreciação de hipóteses esteve centrada nos turnos da professora. Entretanto, conforme a sala se configurou como um fórum no qual ideias devem ser apresentadas e submetidas à crítica, no qual os padrões públicos de apreciação são claros para todos e no qual existe igualdade de autoridade intelectual, pudemos perceber a apreciação e revisão de hipóteses, também, nos turnos dos estudantes que passaram a participar de forma mais ativa no processo de construção de uma explicação para os problemas. Nos momentos de leitura de textos, entretanto, a criticidade esteve menos evidente.

Durante a análise das aulas, percebemos, ainda, algumas relações entre as normas de receptividade à crítica e de padrões públicos de análise que apareceram associadas nos episódios destacados, como se evidencia à medida em que a alteração no conteúdo das respostas dadas pelos estudantes e a revisão de planos de trabalho, estiveram associadas à apresentação e repetição de padrões que definiam o que contava como uma resposta válida. Percebemos, ainda, a importância dessas duas normas para que a sala se configurasse como 
um espaço não só de apresentação de hipóteses ou de planos e métodos de trabalho, mas sim de discussão e revisão desses. Nesse sentido, ainda que a presença de fórum e da igualdade moderada fosse constante, pudemos identificar diferentes maneiras de participação que envolviam maior ou menor criticidade das ideias.

A partir desses resultados, consideramos que, de modo similar ao que acontece nas comunidades científicas, a vigência dessas quatro normas em sala mostrou-se necessária para que ocorresse um processo coletivo de construção de explicações de modo a garantir a ocorrência de interações discursivas críticas. Isso porque, nos momentos da análise em que essas normas estavam menos evidentes ou mesmo ausentes, foi perceptível uma diminuição das operações que remetem à avaliação e revisão de hipóteses e que podem ser associadas às práticas epistêmicas das comunidades científicas, aqui compreendidas como as "maneiras socialmente organizadas e coletivamente realizadas pelas quais os membros de uma comunidade propõem, comunicam, avaliam e legitimam novos conhecimentos" (KELLY; LICONA, 2018, p. 140).

Ao falar sobre o Ensino de Ciências por Investigação, Kelly e Licona (2018) defendem que essa abordagem visa a desenvolver nos estudantes a capacidade de conduzir investigações e, nesse processo, permitir que eles aprendam o conhecimento científico produzido, mas também as práticas das comunidades científicas. Ainda segundo os autores, nessa abordagem de ensino, os estudantes podem vivenciar práticas de construção, comunicação, avaliação e legitimação de explicações que respondam a uma questão científica. De modo similar ao constatado por Kelly e Licona (2018), percebemos nas aulas analisadas que, nos momentos em que as normas sociais estavam vigentes, foram identificadas diferentes maneiras de construir, comunicar e avaliar explicações para os problemas propostos, como apresentamos nas seções anteriores e resumimos a seguir por meios da discussão das práticas culturais evidenciadas nas aulas analisadas.

Para análise das práticas construídas e partilhadas pelo grupo, adotamos como categorias de análise para este trabalho as oito práticas das comunidades científicas nas quais, conforme sugerido pelo NRC (2011), os estudantes devem ser iniciados: fazer perguntas; desenvolver e utilizar modelos; planejar e executar investigações; analisar e interpretar dados; utilizar pensamento matemático e ferramentas de informática; construir explicações; engajarse em argumentações baseadas em evidências; e obter, avaliar e comunicar informações. Como apresentado anteriormente, fizemos essa escolha cientes de que qualquer lista está sujeita ao risco de destacar ou descartar práticas, todavia, optamos por adotar as práticas prescritas pelo NRC (2011) como ferramenta de análise pelo fato de esse documento estar em 
acordo com o referencial teórico sobre o ensino de ciências adotado nesta pesquisa e em razão de a definição e descrição desse conjunto de práticas no documento ser um esforço de elencar práticas das comunidades cientificas de modo a já relacioná-las com o contexto escolar.

A partir desse conjunto de práticas, pudemos identificar diferentes operações realizadas pelos estudantes e pela professora que evidenciam que durante as três aulas analisadas foram criadas oportunidades para que os estudantes se engajassem em processos simplificados do trabalho científico. A cada atividade proposta, algumas práticas recebiam maior ênfase, mas ao longo das aulas, encontramos evidências de todas as práticas sugeridas.

Dentre essas práticas, percebemos uma forte relação entre a prática de fazer perguntas e outras como a argumentação, a análise e interpretação de dados, o uso de pensamento matemático e a construção de explicações, isso porque o papel da professora, e por vezes dos estudantes, ao formular questionamentos que ajudassem no desenvolvimento, articulação e justificativa das hipóteses apresentadas foi relevante nas três aulas. Essas práticas também se relacionam ao planejamento e execução de investigações pelo mapeamento coletivo das informações ou das condições presentes em um texto ou mesmo no enunciado do problema e que devem ser utilizadas em sua resolução. A articulação entre essas práticas nos indica que as interações entre os estudantes e entre esses e a professora foram centrais para que as práticas identificadas fossem produzidas e partilhadas pelo grupo.

Desse modo, defendemos a ideia de que, ainda que o Ensino de Ciências por Investigação, potencialmente, promova oportunidades para que os estudantes vivenciem normas e práticas similares às das comunidades científicas, a efetivação desse potencial depende tanto do perfil da atividade, quanto dos modos como essas são implementadas. Ou seja, as maneiras como as normas e práticas são vivenciadas em sala de aula estão associadas à condução das atividades dada por cada sala, assim como, a presença de uma ou outra prática está articulada aos objetivos, procedimentos e exercício planejados à cada atividade. 


\section{REFERÊNCIAS 6}

AFONSO, A.M.. Alfabetização Científica dos alunos e as ações do professor que corroboram com este processo. 2011. Dissertação (Mestrado em Ensino de Ciências: Modalidades Física, Química e Biologia) - Programa Pós-Interunidades em Ensino de Ciências, Universidade de São Paulo, 2011.

ARROYO, M.G. Fracasso-Sucesso: o peso da cultura escolar e do ordenamento da educação básica. Em Aberto, Brasília, v. 53, p. 46-53, jan/mar, 1992.

BAUMAN, Z. Ensaios sobre o conceito de cultura. Rio de Janeiro: Zahar, 2012.

BERLAND, L.K.; HAMMER, D. Framing for scientific argumentation. Journal of Research in Science Teaching, v. 49, n. 1, p. 68-94, 2012.

BERLAND, L.K.; SCHWARZ, C.V.; KRIST, C.; KENYON,. L.; LO, A.S.; REISER, B.J. Epistemologies in Practice: Making Scientific Practices Meaningful for Students. Journal of Research in Science Teaching, v. 53, n. 7, p. 1082-1112, 2016.

BITTENCOURT, C.M.F. Disciplinas escolares: história e pesquisa. In: OLIVEIRA, M.A.T. de, RANZI, S.M.F. (Orgs). História das disciplinas escolares no Brasil: contribuições para o debate. Bragança Paulistas: EDUSF, 2003.

BLOOME, D, THEODOROU, E. , Analysing teacher-student and student-student discourse. In: GREEN, J.L., HARKER, K.O. (Eds). Multiple perspective analyses of classroom discourse. New Jersey: Ablex Publishing Corporation, 1998.

BLOOME, D., et al. Microethnographic Approach to the discourse analysis of cultural practices in classroom language and literacy events. In: Discourse analysis and the study of classroom language and literacy events: a microethnographic perspective. Malwah: Lawrence Erlbaum Associates, 2005.

BORGES, A.T. Novos rumos para o laboratório escolar de Ciências. Caderno Brasileiro de Ensino de Física, Florianópolis, v. 19, n. 3, p.9-31, dez. 2002

BRASIL. Secretaria de Educação Fundamental. Parâmetros Curriculares Nacionais: ciências naturais. Brasília: MEC/SEF, 1997.

\footnotetext{
${ }^{6}$ De acordo com a Associação Brasileira de Normas Técnicas. NBR 6023.
} 
BROFMAN, P. R. A importância das publicações científicas. Cogitare Enfermagem, Curitiba, v. 17, n. 3. p. 419-421, 2012.

CABRAL, C.C. A Teoria da Investigação de John Dewey: Lógica e Conhecimento. CognitioEstudos: revista eletrônica de filosofia, São Paulo, v. 11, n. 2, p. 167-176, dez. 2014.

CARDOSO RODRIGUES, A.L. A cultura e a organização do conhecimento: desafios teórico-metodológicos, Información, Cultura y Sociedad, Buenos Aires, n. 32, p. 37-58, jun. 2015.

CARVALHO, A.M.P. et al. CARVALHO, A.M.P. et al. Manual do professor. In: Investigar e aprender: ciências, $4^{\circ}$ ano. 1. ed., São Paulo: Editora Sarandi, 2011a. (Coleção investigar e aprender).

Manual do professor. In: Investigar e aprender ciências, $4^{\circ}$ ano. 1. ed., São Paulo: Editora Sarandi, 2011b. (Coleção investigar e aprender).

CARVALHO, A.M.P. O ensino de Ciências e a proposição de sequências de ensino investigativas. In: (Org.). Ensino de Ciências por Investigação: condições para implementação em sala de aula. São Paulo: Cengage Learning, 2013.

CERTEAU, M. Teoria e método no estudo das práticas cotidianas. In: COTIDIANO, CULTURA POPULAR E PLANEJAMENTO URBANO, 1985, São Paulo. Anais... . São Paulo: FAU-USP, 1985.

A cultura no plural. São Paulo: Papirus, 1995.

A invenção do cotidiano: 1. Artes de fazer. 21. ed. Petrópolis: Vozes, 2014.

CHERVEL, A. História das disciplinas escolares: reflexões sobre um campo de pesquisa. Teoria \& Educação, n. 2, p. 177 - 229, 1990.

COSTA, A.F. da; CONCEIÇÃO, C.P.; ÁVILA, P. Cultura científica e modos de relação com a ciência. In COSTA, A.F. da; MACHADO, F.L.; ÁVILA, P. (Eds.). Sociedade e conhecimento: Portugal no contexto europeu. Oeiras: Celta Editora, 2007. 2v. 
DEBOER, G. E. Historical perspectives on inquiry teaching in schools. In: FLICK, L. B.; LEDERMAN, N. G. Scientific inquiry and nature of science: implications for teaching, learning, and teacher education. Berlin: Springer, 2006.

DÍAZ, I.; GARCÍA, M. Más allá del paradigma de la Alfabetización. La adquisición de Cultura Científica como reto educativo. Formación Universitaria, La Serena, v.4, n.2, 2011.

DUSCHL, R. Science Education in Three-Part Harmony: Balancing Conceptual, Epistemic, and Social Learning Goals. Review of Research in Education, v. 32, p. 268-291, fev, 2008.

EAGLETON, T. A ideia de cultura. São Paulo: Ed. Unesp, 2005.

FERRI, G.J. Cultura: sus significados y diferentes modelos de cultura científica y técnica. Revista Iberoamericana de Educación, n. 58, p. 15-33, jan/abr, 2012.

FORD, M.J., Educational Implications of Choosing "Practice" to Describe Science in the Next Generation Science Standards. Science Education, v. 99, n. 5, p. 1041-1048, nov, 2015.

FRAGO, A.V. El espacio y el tiempo escolares como objecto histórico. Contemporaneidade e Educação, Rio de Janeiro, ano 5, n. 7, 2000.

FREIBERG, H.L. Elementos catalisadores para a promoção da negociação de sentidos. 2015. 127 f. Dissertação (Mestrado em educação) - Faculdade de Educação, Universidade de São Paulo, São Paulo, 2015.

GIARD, L. Apresentação. In: CERTEAU, M. A invenção do cotidiano: 1. Artes de fazer. 21. ed. Petrópolis: Vozes, 2014.

GÓMEZ, A.; ADÚRIZ-BRAVO, A. La actividade científica escolar: Una actividade situada. Revista Configuraciones Formativas II: Formación e Praxis, Guanajuato, p. 219 - 236, 2007.

GONZALEZ-HOWARD, M.; MCNEILL, K.L. Learning in a community of practice: factors impacting english-learning students'engagement in scientific argumentation. Journal of Research in Science Teaching, v. 53, n.. 4, pp. 527-553, 2016.

GOODSON, I.F. School Subjects and Curriculum Change: Case Studies in Curriculum History. London: Croom Helm, London, 1983. 
HIRST, P.H.; PETERS, R.S. The logic of education. London: Routledge and Kegan Paul, 1970.

JIMÉNEZ-ALEIXANDRE, M.P., CRUJEIRAS, B. epistemic practices and scientific practices in science education. In: TABER, K.S., AKPNA, B. (Eds). Science Education: na international course companion. Rotterdam: Sense Publishers, 2017.

JULIA, D. A Cultura Escolar como Objeto Histórico. Revista Brasileira de História da Educação, São Paulo, v. 30, n. 1, p. 139-159, jan/jun, 2001.

Disciplinas escolares: objetivos, ensino e apropriação. In: LOPES, A.C.; MACEDO, E. (Orgs.). Disciplinas e integração curricular: história e políticas. Rio de Janeiro: DP\&A, 2002.

KELLY, G. Inquiry teaching and learning: philosophical considerations. In: MATTHEWS, M.R. (Ed.). International Handbook of Research in History, Philosophy and Science teaching. Nova York: Springer, 2014.

KELLY, G.J.; LICONA, P. Epistemic practices and science education. In: MATTHEWS, M.R. (Ed.), History, Philosophy and Science Teaching: New perspectives. Cham: Springer:, 2018.

KRASILCHIK, M. Reformas e realidade: o caso do ensino das ciências. São Paulo em Perspectiva, São Paulo, v.14, n.1, p. 85-93, 2000.

KROPF, S.P.; FERREIRA, L.O. A prática da ciência: uma etnografia no laboratório. História, Ciências, Saúde, Rio de Janeiro, v. 4, n. 3, p. 589-597, nov, 1997.

LA TAILLE., O lugar da interação social na concepção de Jean Piaget. In LA TAILLE; OLIVEIRA, M.K; DANTAS,H. Piaget, Vygotsky, Wallon: teorias psicogenéticas em discussão. 13.ed. São Paulo: Summus, 1992.

LATOUR, B.; WOOLGAR, S. A vida de laboratório: a produção dos fatos científicos. Rio de janeiro: Relume Dumará, 1997.

LAVE, J.; WENGER, E. Situated learning: legitimate peripheral participation. Cambridge: Cambridge University Press, 1991. 
LEÓN, M.P.; COLÓN, A.O.; ALVARADO, F.C. ¿Cómo promover la educación científica en el alumnado de primaria? Una experiencia desde el contexto ecuatoriano. Revista Eureka sobre Enseñanza y Divulgación de las Ciencias, v. 10, n. 2, p. 199-209, 2013.

LETTA, L.A. As ações do professor no ensino fundamental I ao aplicar uma Sequência de Ensino Investigativa (SEI). 2014. 166 f. Dissertação (Mestrado em Ensino de Ciências: Modalidades Física, Química e Biologia) - Programa Pós-Interunidades em Ensino de Ciências, Universidade de São Paulo, 2014.

LONGINO, H.E. The fate of knowledge. Princeton: Princeton University Press, 2002.

LOPES, A. C. Discursos curriculares na disciplina escolar Química. Ciência \& Educação, Bauru, v. 11, n. 2, p. 263-278, ago, 2005.

LORENZETTI, L.. O Ensino de Ciências Naturais nas Séries Iniciais. Revista Virtual: Contestado e Educação, Caçador, v. 2, p. 1-15, 2002.

MACHADO, V.F. A Importância da pergunta na promoção da alfabetização cientifica dos alunos em aulas investigativas de Física. 2012. 151 f. Dissertação (Mestrado em Ensino de Ciências: Modalidades Física, Química e Biologia) - Programa Pós-Interunidades em Ensino de Ciências, Universidade de São Paulo, 2012.

MAIGRET, E. Les trois héritages de Michel de Certeau. Un projet éclaté d'analyse de la modernité. Annales. Histoire, Sciences Sociales. v. 55, n.3, mai/jun, 2000.

MARTINS, I. Dados como diálogo: construindo dados a partir de registros de observação de interações discursivas em salas de aula de ciências. In: SANTOS, F.M.T. dos; GRECA, I.M. (Orgs.). A Pesquisa em Ensino de Ciências no Brasil e suas Metodologias. 2. ed. Ijuí: Unijuí, 2013.

MCCOMAS, W.F.; ALMAZROA, H.; CLOUGH, M. P. The nature of science in science education: an introduction. Science \& Education, Dordrecht, v. 7, n. 6, p. 511-532, 1998.

MEHAN, H. Learning lessons: Social organization in the classroom. Cambridge, MA: Harvard University Press, 1979.

MUNFORD, D.; LIMA, M.E.C. de C. Ensinar ciências por investigação: em que estamos de acordo? Ensaio Pesquisa em Educação em Ciências, Belo Horizonte, v. 9, n. 1, p. 89-11, jun. 2007. 
NATIONAL RESEARCH COUNCIL (NRC). A framework for K-12 science education: Practices, crosscutting concepts, and core ideas. Committee on a Conceptual Framework of New K-12 Science Education Standards. Board on Science Education. Division of Behavioral and Social Sciences and Education. Washington, DC: The National Academies Press, 2011.

NAYLOR, S., KOGH, B., DOWNING, B. Argumentation and Primary Science. Research in Science Education, v. 37, n. 1, p 17-39, mar, 2007.

ORLANDI, E. P. Discurso e leitura. 4. ed. São Paulo: Cortez; Campinas: Editora da Universidades Estadual de Campinas, 2006. (Passando a limpo).

OSBORNE, J. Teaching scientific practices: Meeting the challenge of change. Journal of Science Teacher Education. v. 25, n. 2, p. 177-196, mar, 2014

Defining a knowledge base for reasoning in Science: the role of procedural and epistemic knowledge. In: DUSCHL, R. A.; BISMARCK, A.S. (Eds.) Reconceptualizing STEM Education: the central role of practice. New York: Routledge, 2016.

PARSONS, T. El sistema social. Madrid: Alianza Editorial, 1982.

PASSMORE, C.; STEWART, J.; CARTIER, J. Model-based inquiry and school science: creating connections. School Science and Mathematics, v. 109, n. 7, p. 394-402, 2009.

PATTO, M.H.S. A família pobre e a escola pública : anotações sobre um desencontro.

Psicologia USP, São Paulo, v. 3, n. 1/2, p. 107-121, 1994.

PÉREZ, D.G. et al. Para uma imagem não deformada no ensino de Ciências. Revista Ciência e Educação, Bauru, v. 7, n. 2, p. 125-153, 2001.

PRETI, D. (Org.) Fala e escrita em questão. São Paulo: Humanitas / FFLCH / USP, 2000. (Projetos Paralelos - NURC/SP, 4).

SANDOVAL, A.W. Understanding Students' Practical Epistemologies and Their Influence on Learning Through Inquiry. Science Education, v. 89, n. 4, p. 634-656, 2005.

SASSERON, L.H. Alfabetização Científica no Ensino Fundamental: Estrutura e Indicadores Deste Processo em Sala de Aula. 2008. 265 f. Tese (Doutorado em educação) Faculdade de Educação, Universidade de São Paulo, São Paulo, 2008. 
Interações discursivas e interações em sala de aula: o papel do professor. In:

CARVALHO, A.M.P. (Org.). Ensino de Ciências por Investigação: condições para implementação em sala de aula. São Paulo: Cengage Learning, 2013.

SASSERON, L. H.; DUSCHL, R. A. Ensino de ciências e as Práticas epistêmicas: o papel do professor e o engajamento dos estudantes. Investigações em Ensino de Ciências (Online), v. 21, p. 52-67, 2016.

SCARPA, D.L.; TRIVELATO, S.L.F.. Movimientos entre cultura escolar y cultura científica: análisis de argumentos en diferentes contextos. Magis (Editorial Pontificia Universidad Javeriana), v. 6, p. 87-103, 2013.

SOLINO, A.P. Potenciais Problemas Significadores em aulas investigativas: contribuições da perspectiva histórico-cultural. 2017. 221 f.Tese (Doutorado em Educação) - Faculdade de Educação, Universidade de São Paulo, 2017.

STAKE, E.R. Qualitative Case Studies. In: DENZIN, N.L., LINCOLN, Y.S. (Eds.). The SAGE handbook of qualitative research. Londres: Sage, 2005, 3. ed.

STROUPE, D. Examining Classroom Science Practice Communities: How Teachers as Students Negotiate Epistemic Agency and Learn Science-as-practice. Science Education, v. 98, n.3, abr, 2014. nov, 2015.

Describing "Science Practice" in Learning Settings. Science Education, v. 99, n.6,

VIDAL, D.G. Cultura e práticas escolares: a escola pública brasileira como objeto de pesquisa. Historia de la educación: Revista interuniversitaria, n. 25, p. 153-171, 2006.

. Michel de Certeau e a difícil arte de fazer história das práticas (segunda edição). In:

FARIA FILHO, L.M. (Org.). Pensadores Sociais e a História da Educação. Belo Horizonte: Autêntica Editora Ltda., 2009.

VIECHENESKI, J. P. ; LORENZETTI, L. ; CARLETTO, M.R. Desafios e práticas para o ensino de ciências e alfabetização científica nos anos iniciais do ensino fundamental. Atos de Pesquisa em Educação (FURB), v. 7, p. 853-876, 2012.

WENGER, E., SNYDER, W. M. Comunidades de prática: a fronteira organizacional. Aprendizagem Organizacional/Harvard Business Review. Rio de Janeiro: Campus, 2001. 
WENGER, E. Communities of practice: learning, meaning and identity. Cambridge: University Press, 2016.

WILLIAMS, R. Cultura. In: Palavras-chave. São Paulo: Boitempo, 2007.

WINDSCHITL, M., THOMPSON, J., BRAATEN, M. Beyond the scientific method: ModelBased Inquiry as a new paradigm of preference for school science investigations. Science Education, v. 92, n. 5, p. 941-967, set. 2008.

YIN, R.K. Estudo de caso: planejamento e métodos. 2. ed. Porto Alegre: Bookman, 2001.

ZÔMPERO, A.F., LABURÚ, C.E. Atividades investigativas no ensino de ciências: aspectos históricos e diferentes abordagens. Revista Ensaio. v. 13, n. 3, p. 67-80, set - dez, 2011. 


\section{APÊNDICE A -Transcrição da atividade 1 - A travessia do rio - 17/09/2012 - 42'15” de vídeo}

\begin{tabular}{|c|c|}
\hline 1 & Professora: Bom dia \\
\hline 2 & Estudantes: Bom dia:::: \\
\hline 3 & $\begin{array}{l}\text { Professora: Então a gente vai continuar o projeto ciências e a aula de hoje a gente vai } \\
\text { começar com um probleminha pra vocês resolverem }\end{array}$ \\
\hline 4 & Estudante: A gente já resolveu \\
\hline 5 & $\begin{array}{l}\text { Professora: não... ainda não.... vocês receberam a tirinha com a comanda do problema... aí } \\
\text { está escrito assim“pensa e resolva: três amigos querem atravessar um rio... o barco que } \\
\text { possuem suporta no máximo } 130 \text { quilos... eles têm pesos de } 6065 \text { e } 80 \text { quilos... como } \\
\text { devem proceder para atravessar o rio SEM afundar o barco"... primeiro vocês vão } \\
\text { conversar no grupo de vocês... primeiro é com vocês em cada grupo... vocês vão pensar } \\
\text { como é que vai resolver isso... quando o grupo chegar em uma conclusão... pensar em uma } \\
\text { maneira... aí vocês vão me chamar para falar qual é a ideia de vocês... aí a gente vai ouvir } \\
\text { a ideia de cada um pra ver qual é a que vai da certo... tá bom? [Estudantes: sim...tá....] } \\
\text { então pode começar }\end{array}$ \\
\hline 6 & Renan: (inaudível) \\
\hline 7 & $\begin{array}{l}\text { Professora: Renan... não são } 60 \text { pessoas (inaudível ) ((os estudantes conversam nos grupos. } \\
\text { A compreensão das conversas não é viável, mas observamos estudantes escrevendo nos } \\
\text { cadernos e utilizando os dedos das mãos como instrumento de cálculo. A professora circula } \\
\text { pela sala parando por alguns instantes no grupo 3)) }\end{array}$ \\
\hline 8 & $\begin{array}{l}\text { Professora: E aí o que vocês tão pensando? hã? não entendi.. então explica melhor como é } \\
\text { que é assim? como é que é essa ideia? }\end{array}$ \\
\hline 9 & Joana: Vai um (no barco) empurra o outro (inaudível) \\
\hline 10 & $\begin{array}{l}\text { Professora: O gente a Joana deu uma ideia aqui... ela falou assim... que um vai... vai um de } \\
\text { cada vez só que ele vai e empurra o barco de volta... só que a distância é muito grande e } \\
\text { não dá para empurrar o barco de volta... entendeu? }\end{array}$ \\
\hline 11 & Estudante: Só ir nadando... \\
\hline 12 & $\begin{array}{l}\text { Professora: Não pode ir nadando... tem que ir no barco... então a gente tem que eliminar } \\
\text { algumas ideias aí para você snão falarem novamente... ((a professora escreve na lousa as } \\
\text { ideias que tem que ser eliminadas)) então é... tem que ir no barco... tem que ir para o outro } \\
\text { lado NO barco... então não pode ir de OUTRA forma... tem que ser no barco tá? uma outra } \\
\text { coisa... o rio é bem grande... então não dá para empurrar o barco de volta... se fosse uma } \\
\text { distância curtinha não precisava ir de barco concorda? então não dá para empurrar o barco } \\
\text { de volta. }\end{array}$ \\
\hline 13 & Maria: Só se tivesse alguém para empurrar aí pegava a gente e levava depois trazia e levava \\
\hline 14 & Professora: Sim... olha aqui o que a Maria falou... repete Maria... bem alto \\
\hline 15 & $\begin{array}{l}\text { Maria: Uma pessoa entrava no barco para pegar uma que está desse lado e levar para o } \\
\text { outro }\end{array}$ \\
\hline 16 & $\begin{array}{l}\text { Professora: Ahãn...mas não tem essa pessoa tem só AS TRÊS pessoas... a três estão desse } \\
\text { lado aqui do rio... as TRÊS estão ali e tem que chegar do OUTRO lado do rio... o barco tá } \\
\text { parado ali tá vazio... as três pessoas precisam atravessar... só que o barco suporta apenas } \\
130 \text { quilos e cada um tem } 60 \text { outro tem } 65 \text { e o outro tem } 80 \text { quilos tá? é isso que vocês têm }\end{array}$ \\
\hline
\end{tabular}


que pensar... ((Fabrício, no grupo 6 levanta a mão)) fala Fabrício!

17 Fabrício: E se colocasse uma corda no barco? um vai lá... vai o outro e puxa o barco

18 Professora: Não... essa ideia também não dá.. por que não tem corda... só tem o barco e o rio é bem grande ((professora aponta para as anotações na lousa)) lembra que eu já falei

((Ariel, no grupo 5 levanta a mão e a professora aponta para ele))

19 Ariel: Vai um de cada vez...

20 Professora: Um de cada vez? me explica melhor como é que é isso

21 Ariel: Vai (inaudível)

22 Professora: Peraí... o::: escuta isso isso aqui ((professora aponta para Natan no grupo 2)) fala bem alto o que você falou

23 Natan: Como é que você vai trazer o barco de volta?

24 Professora: Se for um de cada vez... olha o que o Natan falou... se for um de cada vez como é que ele vai e vai trazer o barco de volta?

25 Estudante: A não ser que fosse um navio

26 Maria: Só se for uma corda só

27 Professora: A ideia da corda a gente já superou lembra?

28 Luiz: (inaudível)

29 Professora: Ahn? ((professora aponta para Luiz no grupo 1)) não tem motor não...

(inaudível) mas mesmo que tiver motor ué... [Maria: não tem ninguém para dirigir]

entendeu? Mesmo que tenha vai... mesmo que tenha motor ((Fabrício levanta a mão))

30 Luiz: Então como vai chegar do outro lado?

31 Professora: Então... essa que é a pergunta como é que vai chegar do outro lado?

32 Professora: Peraí, vamos ouvir o Fabrício agora.

33 Fabrício: (inaudível)

34 Professora: Muito bem... essa ideia do Fabrício é legal... fala de novo mais alto... presta atenção para ver se vocês concordam com ele.

35 Fabrício: Um dos amigos vai... deixa um lá pega o outro e volta

36 Professora: Sim isso é legal, só que cê tem que pensar em uma coisa... o barco só comporta 130 quilos... e aí um tem 60 o outro tem 65 e outro tem 80 quilos ((Diego na mesa janela 1 levanta a mão e a professora aponta para ela, mas o grupo continua conversando)) peraí... peraí

37 Diego: Então vai dois em um barco só um de 60 e 65 (inaudível)

38 Professora: Peraí peraí... tá... entendi o que você quis dizer.. ele falou assim que vai dois... um de 80 e um de $65 .$. eu quero saber se vai dar certo... [Diego: não... eu disse um de 60 e $65 \ldots$ por que senão não dá certo]

39 Maria: O de 60 e 65 precisa ir primeiro

40 Professora: Ahn? peraí... o de 60 e 65 eles podem ir juntos o barco?

41 Estudantes: Pode

42 Professora: Por quê? ((apontando para Fabrício com a mão levantada))

43 Fabrício: Pode porque vai dar 125

44 Professora: Vai dar 125 quilos... aí cabe no barco e vai dar certo? o barco não vai afundar se os dois forem juntos? por que comporta quanto?

45 Estudantes: 130

46 Professora: Quanto que comporta o barco?

47 Estudantes: 130 
48 Professora: $130 \ldots$ então tá... vai o de $65 \ldots$ vai e o de 60

49 Fabrício: Mas não dá o de 80 porque vai dar 14. Por que zero mais zero (inaudível)

50 Professora: Não... Mas peraí... vamos pensar por partes... o Diego falou que vai o de 60 e o de 65 tá... eles vão no barco e atravessa o rio... e aí? o que vai acontecer depois?

51 Estudantes: (inaudível - estudantes falando ao mesmo tempo)

52 Professora: O pessoal presta atenção

53 Diego: O de 60 volta para pegar o de 80

54 Professora: O de 60 volta...

55 Diego: ... pra pegar o de 80 aí vai os dois juntos

56 Professora: O que vocês acham o::: vai o de 60 ou o de 65 ?

57 Estudantes: (inaudível)

58 Professora: Vai para outro lado... e aí quem é que volta?

59 Estudante: $\mathrm{O}$ de 60 (inaudível)

60 Professora: O de 60 e o de 65 dá certo? dá? Fábio você concorda?

61 Fábio: O quê?

62 Professora: Como vai resolver esse problema de atravessar o rio? ((estudantes discutem entre si os cálculos dos quilos que o barco suporta))

63 Professora: Está passando a soma que você fez?

64 Fabrício: [inaudível]

65 Professora: Espera aí um pouquinho

66 Fábio: Eu fiz: 130 mais 60 deu 190.

67 Professora: Nossa... mas você está somando a capacidade que o barco tem e mais o quê?

68 Maria: Ele está somando as pessoas

69 Professora: Com o que o barco comporta... mas dá para fazer assim? atravessar o barco...o...rio? é a solução?

70 Maria: Não professora!

71 Professora: E aí, qual é a solução? é a vez do Ariel... fala

72 Ariel: (inaudível) ((professora não responde ao estudante e volta a circular pela sala, aproximando-se do grupo 5))

73 Professora: E aí Manoel, você não falou nada hoje!

74 Manoel: (inaudível) Dois vai... deixa um e pega outro...

75 Professora: Mas quem são os dois que vão?

76 Manoel: O de 60 e o de 65.

77 Professora: Tá... o de 60 e o de 65 pode ir e vai dar quanto?

78 Manoel: 125

79 Professora: Aí eles podem ir.... tá bom... mas e aí quem é que volta?

80 Manoel: $\mathrm{O}$ de 60 pega o de 80

81 Professora: E o de 60 com o de $80 \ldots$ eles podem estar no barco os dois?

82 Estudante: Não vai dá professora.

83 Professora: Vai dá? ((apontando para estudante))

84 Estudante: 140.

85 Professora: E aí se der 140... Fábio::: o barco afunda... por quê?

86 Estudante: Por que não pode passar de $130 \ldots$ 
87 Professora: Por que não pode passar de 130

88 Estudante: E já passou... deu 140

89 Professora: Então como é que a gente vai fazer?

90 Estudante: Está difícil essa daí.

91 Maria: Está mesmo.

92 Estudante: Até a professora não consegue.

93 Professora: Até eu não consigo ... é que é a vez de vocês pensarem agora

94 Estudante: Professora o Fabrício quer falar

95 Professora: Fala Fabrício.

96 Fabrício: O que eu pensei não vai dar certo.

97 Professora: Mas fala de repente...

98 Fabrício: Se a gente levasse... o 80 levasse o de 65 ou o 60 e o 60 ia buscar o

99 Professora: Peraí o de 80 pode buscar o de 60? a gente acabou de conversar ali.

100 Fabrício: por isso disse que não ia dar certo.

101 Professora: A::: tá... mas valeu tentar ((professora volta a circular nos grupos))

102 Estudante: Professora ela falou que você não sabe fazer

103 Professora: E ela sabe? eu quero saber quem sabe

104 Estudantes: (inaudível)

105 Professora: Não tem corda

106 Maria: Não tem pessoas

107 Professora: É o que tem pra hoje... um barco três pessoas e o rio... um de 60 um de 80 e um de 65 ... e aí?

108 Estudantes: Está difícil.

109 Professora: Pensem aí que eu vou pegar um copo d'água. ((estudantes ficam conversando enquanto a professora busca um copo de água. Ouvimos alguns cálculos e discussões sobre o problema))

110 Estudantes: Professora! Professora!

111 Professora: E aí? Vamos ver aqui o que a Irene pensou, oh!...

112 Irene: (inaudível)

113 Professora: Meu amor você não pensou ainda... então pensa aí... quem pensou?

114 Estudantes: O Fabrício

115 Professora: Hum... fala Fabrício

116 Fabrício: Eu não sei

117 Professora: Fala... vamos pensar juntos... qual é sua ideia?

118 Fabrício: Não vai dar certo

119 Estudantes: FALA... TENTA

120 Professora: Fala que a gente pode ter outra ideia.. peraí.

121 Fabrício: Se o de 60 ((outros estudantes falam junto))

122 Professora: Peraí... peraí... fala

123 Fabrício: Se o de 60 fosse buscar o de $65 \ldots$ ia dar 125 ai não ia dar porque o de 65 não tem como buscar o de 80

124 Professora: Entendi... então... esse é o problema... agora a gente tem que pensar em como

é que a gente vai fazer para resolver isso... fala Israel 
125 Israel: (inaudível)

126 Professora: Espera aí... olha a ideia do Israel agora

127 Israel: Tem que tirar o de 80 porque o de 80 não cabe... e o de 60 e 65(inaudível)

128 Professora: Mas o de 80 precisa ir também... não é porque ele é gordinho que ele tem que

ficar... ele precisa chegar do outro lado entendeu? ele precisa ir também você vai deixar

ele lá coitado? assim não pode.

129 Estudante: (inaudível)

130 Professora: Mas não tem outra pessoa lembra? e ele precisa chegar lá também.

131 Diego: Professora?

132 Professora: Oi

133 Professora: Olha o Israel queria deixar o de 80 quilos lá e ir só os dois... mas não pode tem que ir os três... eles têm que chegar do outro lado do rio.

134 Professora: Fala Diego

135 Diego: (inaudível)

136 Professora: Oh! Escuta aí o Diego

137 Diego: (inaudível) se o de 80 for ...tem que ser raso... um vai até a metade do rio, outro sai...(inaudível)

138 Professora: Lembra que não pode nadar? eles têm que chegar SECO do outro lado... não pode chegar molhado não

139 Carolina: $\mathrm{O} 60$ com 65 vai dar $125 \ldots$

140 Professora: Hã! Isso... peraí... fala Carolina.

141 Carolina: O 60 busca o 65 e aí dá 125

142 Professora: SIM...e o de 80, como é que faz? lembra que tem barco três pessoas e o rio... estão de um lado e têm chegar do outro... fala Ariel!

143 Ariel: (inaudível)

144 Professora: Todos podem ir no barco os três?

145 Estudantes: Não!

146 Professora: Por quê? ((estudantes falam ao mesmo tempo))

147 Estudante: Porque dá mais que 130

148 Professora: O barco comporta apenas...

149 Estudantes: 130.

150 Professora: E os três juntos pesa quanto? quanto que pesa os três juntos?

151 Estudante: 205.

152 Professora: $205 \ldots$ pode ir 205 quilos no barco?

153 Estudantes: Não ((estudantes começam a conversar sobre as possibilidades))

154 Professora: E aí? como é que a gente vai fazer? a gente precisa descobrir... consegue...

vamos gente... pra tudo tem um jeito... vamos tentar? Pra tudo tem um jeito... o.:: quem é que pode ir primeiro.

155 Maria: 65 e 60.

156 Professora: Hã? tá bom

157 Carolina: (inaudível)

158 Professora: Hã??? peraí... presta atenção aqui no que a Carolina falou

159 Carolina: 80 busca o 60 e depois o de 60 busca o de 65 .

160 Estudante: mas 80 mais 60 é 140. 
161 Professora: Entendeu? ((estudantes voltam a conversar sobre as possibilidades, mas o áudio é incompreensível))

162 Estudantes: Você não sabe?

163 Professora: Sim... sim... eu sei sim... eu sei a resposta vocês é que estão descobrindo ainda

164 Estudantes: Não leva o gordinho ou ele faz dieta

165 Professora: Mas não dá tempo para ele fazer dieta...se ele fizer vai anoitecer e não vai dar tempo ((estudantes seguem com a discussão e ao fundo começam a ser frequentes

conversar paralelas, como algumas meninas falando que a colega estaria namorando))

166 Estudantes: dica dica DICA

167 Professora: A gente já sabe que vai dar certo do 60 ir junto com o de $65 \ldots$ tá bom? estou dando a dica... a gente já descobriu isso... e aí, como é que vai fazer para o de 80 também chegar do outro lado? [Estudante: vai nadando] Carolina... você chegou perto... o que foi que você falou aquela hora? [Estudante: vai nadando] daquela vez

168 Carolina: O de 60 vai com o de $65 \ldots$ e vai o de 80 (inaudível)

169 Professora: Vai os três? não dá... afunda o barco.

170 Maria: Vai um segurando... nadando assim

171 Professora: Vamos fazer assim ó... faz de conta que o Rian... vem cá... o Rian é a pessoa... isso.. ele é o maior então ele é o de $80 \ldots$ faz de conta que ele... o Hugo é o de 65 levanta (( os dois meninos se aproximam da professora no centro da sala)) e o Natan é o de $60 \ldots$ os três estão lá do outro lado do rio ... encosta lá na parede ((os três vão até a aparede da janela)) é 8065 e 60 quilos... tá? faz de conta que tem um barco aqui vazio parado na beira do rio.

172 Fabrício: Pega a cadeira prô

173 Professora: Não...você senta na cadeira Fabrício e presta atenção ((a professora se dirige para o outro lado da sala))

174 Professora: Aqui ó... é o outro lado do rio... como é que a gente vai atravessar os três pra lá?

175 Estudante: Vai o de 60 (inaudível)

176 Professora: Peraí.... peraí... quem é que vai primeiro no barco?

177 Estudante: Vai o de 60 [Natan: eu]

178 Professora: Vamos por o de 60 no barco ((a professora puxa o estudante para perto de si no centro da sala)) o de 60 já está no barco... e agora?

179 Estudantes: 65

180 Professora: Põe o de 65 ((traz o segundo Estudante para o centro)) beleza

181 Maria: Agora leva pra lá ((apontando para o outro lado. As crianças que representam os homens de 60 e 65 quilos vão para o outro lado da sala))

182 Professora: Vai... o barco leva os dois para o outro lado do rio... vai lá... para aí do outro lado do rio... vai lá

183 Maria: Aí o de 60 vem.

184 Professora: E agora quem é que vai voltar?

185 Estudantes: $\mathrm{O}$ de 60.

186 Professora: Tá... vem cá... agora vem aqui... quanto é que ele pesa mesmo... o Natan??

187 Fabrício: 60

188 Professora: 60 e quanto é que o Rian pesa?

189 Estudantes: 80. 
190 Professora: $80 \ldots$ eu posso por os dois no barco?

191 Estudantes: Não

192 Professora: Vai dá?

193 Estudantes: 140

194 Professora: 140 vai acontecer o quê? [estudantes: vai afundar] vai afundar... então...

195 Adriano: Professora (inaudível)

196 Professora: Olha que legal aquilo que ele pensou o... olha o que que o Adriano falou...

repete bem alto para ver se está certo isso

197 Adriano: O de 80 vai... aí o de 65 volta para pegar o de 60

198 Professora: Vamos tentar para ver se dá certo?

199 Estudantes: Vamos!

200 Professora: Quem é o de 80? Vem cá! Só ele? ((Rian vai ao centro com a professora))

201 Estudante: Não! E o de 60 ?

202 Professora: Hã? não... a ideia do Adriano tá?

203 Adriano: Só ele

204 Professora: Só ele... ele pode ir sozinho no barco?

205 Estudantes: Pode

206 Professora: Então tá vamos... vai... o barco levou o de 80 ((Rian vai para o outro canto da sala))

207 Maria: O de 65 vem para buscar o de 60 e leva pra lá

208 Professora: Volta de 65 ((Hugo volta))

209 Diego: Aí... deu certo professora

210 Professora: Pode entrar no barco os dois?

211 Estudante: Pode

212 Professora: Então vai ((os dois meninos vão para o outro lado da sala))

213 Estudantes: E:::: ((a sala bate palmas e os três meninos voltam para seus lugares e a professora distribui uma folha branca com cabeçalho e um enunciado para cada estudante))

214 Professora: Então agora vocês receberam uma folhinha... cuidado senão você vai cair... que está escrito assim.... nome..... vocês vão completar aí com o nome de vocês e responder"agora que você já resolveu o desafio da travessia do rio, escreva e desenhe o que você fez para resolver o problema" tá? O que VOCÊS fizeram... o que vocês fizeram para chegar na resposta? na resposta... o que a gente fez para chegar na resposta? o que é que a gente teve que pensar ali?

215 Estudantes: O de 60 e o de $65 . .$. (inaudível) ... aí o outro foi e veio de $80 \ldots$ o de 80 foi.... aí veio de 60 e buscou o de 65

216 Professora: Sim.... mas o que é que nós fizemos de ficar nisso... 80 mais 60 mais... o que é isso que que a gente fez?

217 Estudante: Contas

218 Professora: Hã?

219 Estudante: Contas.

220 Professora: Nós fizemos cálculos... né? contas...tivemos que fazer cálculos... e aí porque foi possível... olha a outra pergunta Fábio"Por que foi possível levar as três pessoas para o outro lado do rio?" por quê?

221 Estudantes: (inaudível) ((todos falam ao mesmo tempo))

222 Professora: Fábio... senta.... Fábio por favor senta... então... mas aí porque que foi 
possível? se a gente tivesse colocado mais de 130 teria acontecido o que?

223 Estudante: Afundado

224 Professora: Então porque que não afundou? por que que eles conseguiram atravessar?

225 Estudante: Por causa do cálculo

226 Professora: Porque a gente calculou? e aí colocou o peso certo e deu para atravessar? tá... então responda aí as perguntas.... Renan!!!

227 Diego: Desenhe! Desenhe!

228 Professora: A:: desculpa... desenhe... desenhe o que você fez... e na de baixo é respondam por QUE foi possível levar as três pessoas para o outro lado do rio... Quem ainda tem dificuldade para escrever desenhe também... mas quem consegue escrever... já dá ((cada estudante faz sua atividade e escutamos algumas conversas em voz baixa ao fundo)) 


\section{APÊNDICE B - Transcrição das atividades 6 e 7 - A questão da água de lastro - 29/10/2012 - 26'27" de vídeo}

\begin{tabular}{|c|c|}
\hline 1 & $\begin{array}{l}\text { Professora:gente hoje é leitura né? e eu não vou ficar brigando com vocês toda hora } \\
\text { para vocês prestarem atenção... então POR FAVOR }\end{array}$ \\
\hline 2 & Professora: Bom dia \\
\hline 3 & Estudantes: Bom dia \\
\hline 4 & Professora: Na outra aula sobre o projeto de ciências nós falamos sobre o quê? \\
\hline 5 & Estudantes: Embarcações \\
\hline 6 & Professora: Sobre as embarcações... o que sobre as embarcações? \\
\hline 7 & Estudantes: Navio afundando (inaudível) \\
\hline 8 & $\begin{array}{l}\text { Professora: Em que né? pra que as embarcações são utilizadas? e o que mais? elas são } \\
\text { todas iguais? }\end{array}$ \\
\hline 9 & Estudante: è em que as embarcações são utilizadas \\
\hline 10 & Estudantes: Não. \\
\hline 11 & Professora: Elas são diferentes... por quê? \\
\hline 12 & $\begin{array}{l}\text { Estudantes: ((falas indiscriminadas e ao mesmo tempo)) alguns passear, outras para } \\
\text { trabalhar, diversão... }\end{array}$ \\
\hline 13 & Professora: E alguns carregam o quê? \\
\hline 14 & Estudantes: Carros, pessoas... \\
\hline 15 & Professora: Carros... pessoas... e o que mais? \\
\hline 16 & Estudantes: Peixe \\
\hline 17 & $\begin{array}{l}\text { Professora: Peixe... cargas né? as embarcações podem carregar pessoas ou cargas né? } \\
\text { de VÁRIAS coisas... muitas coisas diferentes... e vocês receberam um texto aí... e } \\
\text { agora nós vamos falar sobre como as embarcações se mantém na água... vocês } \\
\text { lembram da experiência do barquinho? o que é que fazia o barquinho flutuar direitinho } \\
\text { com a carga? hã? }\end{array}$ \\
\hline 18 & Estudante: (inaudível) \\
\hline 19 & Professora: Não... a experiência com as pecinhas de ferro... por que que afundava? \\
\hline 20 & Maria: O peso... todo de um lado. \\
\hline 21 & Professora: Isso... quando o peso estava só de um lado o que acontecia? \\
\hline 22 & Estudantes: Afundava \\
\hline 23 & Professora: Então o que é que fazia o barco ficar legal lá na água? \\
\hline 24 & Estudantes: Tinha que colocar lá no outro lado \\
\hline 25 & $\begin{array}{l}\text { Professora: Tinha que distribuir as peças né? e isso acontece com qualquer } \\
\text { embarcação... se colocar muita carga... de qualquer jeito... o que é que vai acontecer? }\end{array}$ \\
\hline 26 & Estudantes: Vai afundar. \\
\hline 27 & $\begin{array}{l}\text { Professora: Vai afundar né... Talita? então o que é que a gente deve fazer em qualquer } \\
\text { embarcação tanto no mar quanto no rio... o que é que tem que fazer para a embarcação } \\
\text { ficar lá legal flutuando? }\end{array}$ \\
\hline 28 & Estudantes: Distribuir \\
\hline 29 & Professora: Distribuir o peso....DIEGO Senta e presta atenção... pega o seu texto \\
\hline 30 & Fabrício: Gravou aí... oh! \\
\hline
\end{tabular}




\begin{tabular}{|c|c|}
\hline 31 & $\begin{array}{l}\text { Professora: Nós vamos começar a leitura..."Mantendo navios na água”... para } \\
\text { acompanhar agora... tá? Adriano! “Acabamos de ver que os barcos podem ser } \\
\text { utilizados como meio de transporte, tanto para cargas em geral"... Diego ainda é o } \\
\text { texto... eu ainda não pedi para pegar a ilustração... por favor... pegue o texto... } \\
\text { "Devemos estar sempre atentos para a capacidade de carga de uma embarcação, pois o } \\
\text { excesso pode implicar no seu AFUNDAMENTO devido ao grande peso e a falta de } \\
\text { carga também pode resultar em problema já que o navio fica instável, ou seja, não se } \\
\text { mantém equilibrado sobre a água e pode tombar.”...isso que dizer que o navio vazio... } \\
\text { ele fica muito leve e também pode... ((faz gestos com as mãos balançando de um lado } \\
\text { para o outro mostrando a instabilidade do navio)) tombar esse navio ou essa } \\
\text { embarcação.... então... a falta de peso Fabrício... também pode prejudicar a } \\
\text { embarcação... "Para evitar que as embarcações tenham o problema de falta de } \\
\text { estabilidade, os navios são providos de tanques onde é colocado o chamado Lastro.”... } \\
\text { tanque de Lastro... vamos ver o que é isso... }\end{array}$ \\
\hline 32 & Ariel: eu leio lasto? \\
\hline 33 & 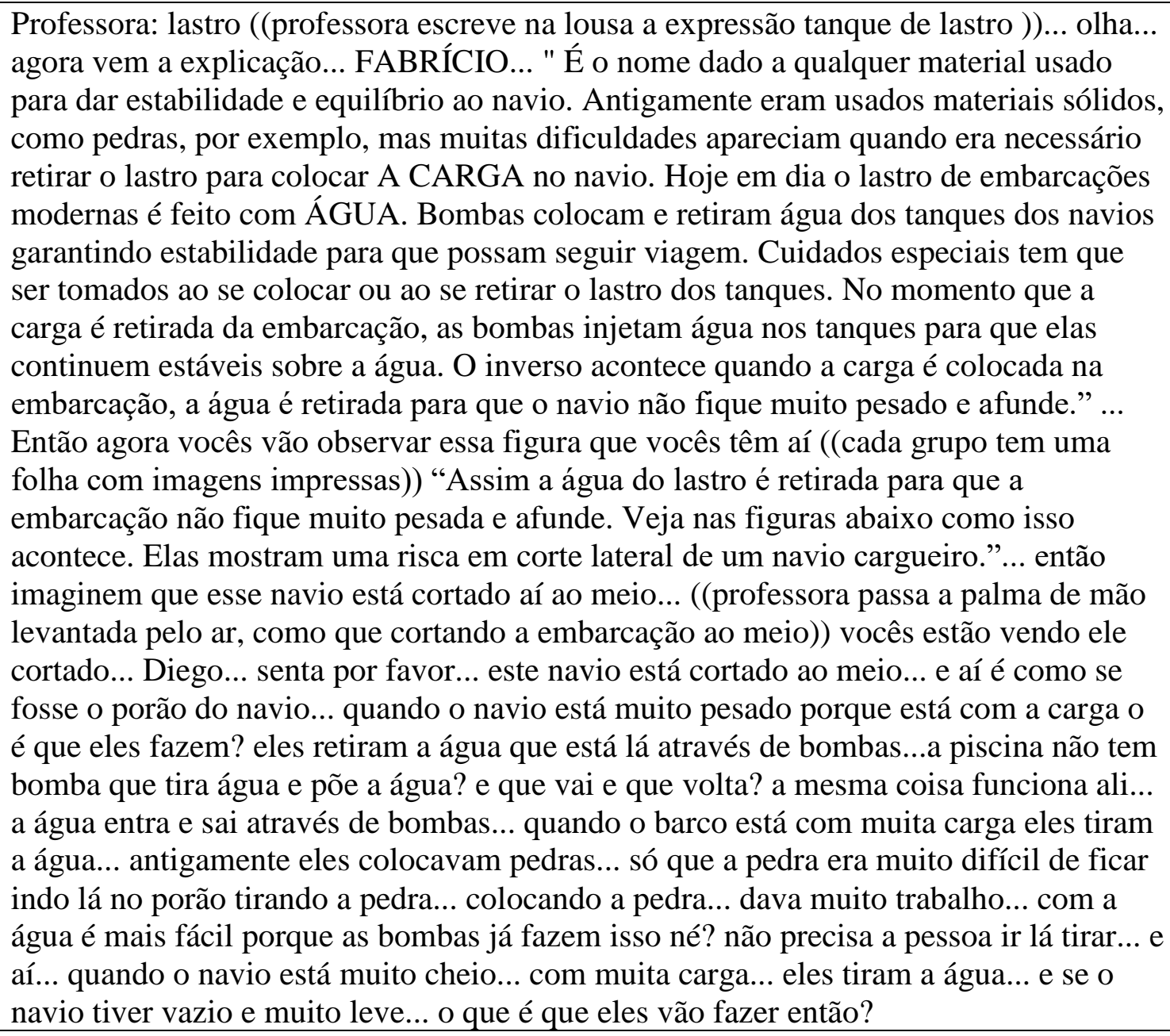 \\
\hline 34 & Maria: Ele vai afundar \\
\hline 35 & Professora: E aí... o que \\
\hline 36 & Fabrícioa sugar a água \\
\hline 37 & Professora ahn? \\
\hline 38 & Fabrício: Sugar a água para o tanque \\
\hline 39 & $\begin{array}{l}\text { mo Fabrício... então } \\
\text { né? do tanque de }\end{array}$ \\
\hline
\end{tabular}




\begin{tabular}{|c|c|}
\hline & $\begin{array}{l}\text { lastro... e se o navio estiver vazio... já estiver deixado a carga lá... o que é que } \\
\text { acontece? o navio chegou... deixou a carga... está vazio... está leve o que é que eles } \\
\text { fazem para sair? o que é que está acontecendo aí na segunda figura? }\end{array}$ \\
\hline 40 & Maria: O barco está afundando porque está leve \\
\hline 41 & Professora: é... o que está escrito aí na segunda figura \\
\hline 42 & Estudante: O barco está afundando porque está leve \\
\hline 43 & Professora: NÃO lê o que está escrito aí na segunda figura \\
\hline 44 & Estudante: (inaudível) água de lastro \\
\hline 45 & $\begin{array}{l}\text { Professora: Tanque de lastro o quê? você não terminou de ler.... cheio.... se está sem } \\
\text { carga o tanque de lastro tem que estar? }\end{array}$ \\
\hline 46 & Maria: Cheio. \\
\hline 47 & $\begin{array}{l}\text { Professora: Cheio. E aqui na última figura, ó? bom... vamos começar lendo a } \\
\text { primeira... "Carga sendo retirada"... então o navio chegou lá e a carga está sendo } \\
\text { retirada... ao mesmo tempo que a carga está sendo retirada... o que é que está } \\
\text { acontecendo lá em baixo? }\end{array}$ \\
\hline 48 & Maria: A água está saindo ((olhando a ilustração)) \\
\hline 49 & $\begin{array}{l}\text { Professora: Ela está saindo... hã? está escrito aí o que está acontecendo... está escrito o } \\
\text { que está acontecendo lá em baixo }\end{array}$ \\
\hline 50 & Maria: "Tanque de lastro se enchendo" ((lendo a legenda da ilustração)) \\
\hline 51 & $\begin{array}{l}\text { Professora: Se enchendo... a carga está sendo retirada e ao mesmo tempo o tanque está } \\
\text { se enchendo... por quê?Porque não pode tirar toda a carga para depois encher o } \\
\text { tanque... né? então a carga vai sendo tirada e a água vai sendo colocada... "No porto de } \\
\text { origem retirando a carga e carregando a água de lastro" ... na segunda figura ele já está } \\
\text { sem a carga... e aî? o que é que acontece com o tanque? quando já está sem a carga o } \\
\text { que acontece com o tanque de lastro aí? }\end{array}$ \\
\hline 52 & Estudantes: Cheio \\
\hline 53 & $\begin{array}{l}\text { Professora: Cheio... ela já está cheia... encosta sem carga e cheia de água de lastro.... } \\
\text { porque já tirou... né Manoel? a carga... e aí o tanque já tem que estar cheio senão o } \\
\text { navio pode tombar... e lá embaixo quando novamente este navio está sendo } \\
\text { carregado... ó... carga sendo carregada... o que acontece ao mesmo tempo quando a } \\
\text { carga está sendo carregada? }\end{array}$ \\
\hline 54 & Estudantes: A água tá saindo do tanque... té esvaziando \\
\hline 55 & $\begin{array}{l}\text { Professora: Tem que ir esvaziando esse tanque para ir equilibrando o peso... "No porto } \\
\text { de destino, recebendo carga e descarregando água de lastro" ... então quando a carga } \\
\text { está sendo retirada o tanque tem que estar sendo enchido... e quando é ao contrário... } \\
\text { né o Diego? e quando a carga está sendo colocada o tanque de lastro tem que se } \\
\text { esvaziar... presta atenção aqui em uma pergunta, Talita... "Um navio mercante aportou } \\
\text { no porto de Bilbao na Espanha. Carregado de frutas do vale do São Francisco da Bahia } \\
\text { e Pernambuco. Após descarregar todas as frutas o navio não tinha carga para retornar } \\
\text { ao Brasil"... estava vazio... descarregou as frutas e ficou vazio, Fabrício... "Que } \\
\text { medidas o capitão deverá tomar para retornar com segurança ao seu porto de } \\
\text { origem?"... na verdade... o que é que ele já tinha que estar fazendo quando as frutas } \\
\text { estavam sendo descarregadas? }\end{array}$ \\
\hline 56 & Estudantes: Enchendo o tanque. \\
\hline 57 & $\begin{array}{l}\text { Professora: Enchendo o tanque de lastro...beleza... agora uma outra situação "Um } \\
\text { transatlântico aportou no porto de Santos em São Paulo. Chegando da cidade de } \\
\text { Valparaíso, no Chile. Ele chegou sem passageiros e somente com a tripulação. O } \\
\text { cruzeiro que se iniciará em Santos e passará por todo o litoral sudeste do país está }\end{array}$ \\
\hline
\end{tabular}




\begin{tabular}{|c|c|}
\hline & $\begin{array}{l}\text { completo, ou seja, o navio estará navegando com sua carga completa. O que o capitão } \\
\text { deverá fazer de diferente de quando chegou com o navio vazio agora que o navio está } \\
\text { completo?’... quando o navio chegou vazio de carga... Diego... como é que estava o } \\
\text { tanque de lastro? }\end{array}$ \\
\hline 58 & Estudantes: Cheio \\
\hline 59 & $\begin{array}{l}\text { Professora: Cheio... e aí as pessoas foram entrando... o que é que tinha que estar } \\
\text { acontecendo ao mesmo tempo? }\end{array}$ \\
\hline 60 & Talita: a água esvaziando \\
\hline 61 & $\begin{array}{l}\text { Professora: A água tinha que estar sendo... né? jogada para fora do tanque e na água... } \\
\text { para que o tanque ficasse o quê? }\end{array}$ \\
\hline 62 & Estudantes: Vazio \\
\hline 63 & $\begin{array}{l}\text { Professora: Vazio... e o barco ficasse só com o peso da carga... tá? todos olhem a } \\
\text { figura aí do tanque de lastro.. olhe e passa para o colega para olhar... o que vocês } \\
\text { acham que entra no tanque de lastro quando a água é colocada lá? hein... Fabrício? } \\
\text { quando a água é colocada no tanque de lastro vocês acham que é só ÁGUA que entra } \\
\text { lá? }\end{array}$ \\
\hline 64 & Estudantes: Não... peixe \\
\hline 65 & Professora: Peixe... e o que mais?o que mais que tem no fundo do mar... será.. hein??? \\
\hline 66 & Estudantes: Tubarão... golfinho... baleias \\
\hline 67 & $\begin{array}{l}\text { Professora: Na verdade não vai entrar animais muito grandes... coisas muito grandes... } \\
\text { porque o espaço... não sei ao certo o tamanho da entrada da bomba... mas eu sei que } \\
\text { não é tão grande para entrar um tubarão... vai entrar coisas menores }\end{array}$ \\
\hline 68 & Diego: Tartaruga \\
\hline 69 & $\begin{array}{l}\text { Professora: Peixes pequenos... tartarugas pequenas... e o que mais existe no mar? } \\
\text { pequenos... né? não pode ser do tamanho de uma baleia... por exemplo }\end{array}$ \\
\hline 70 & Estudante: Conchas... estrela do mar \\
\hline 71 & $\begin{array}{l}\text { Professora: Conchas, peixes, tartarugas, estrelas do mar... enfim... vários animais que } \\
\text { VIVEM no fundo do mar... e até mesmo o LIXO que as pessoas jogam na praia... Vai } \\
\text { parar no fundo do mar né? e pode acabar entrando no tanque de lastro... então agora } \\
\text { nós vamos ler o segundo texto aí da folhinha... acompanha aí Ariel ... o segundo texto } \\
\text { que tem na folhinha... Diego... segundo texto que tem na folhinha“Vida marinha na } \\
\text { água de lastro. O navio de grande porte pode atravessar os mares, indo, por exemplo, } \\
\text { do Brasil à China.”.... senta direitinho Diego e acompanha seu texto... por favor... senta } \\
\text { direito na cadeira... "Em cada um desses portos sua carga pode se alterar, podem sair } \\
\text { ou entrar passageiros, entrar carga e sair água dos tanques e, pode também, sair carga e } \\
\text { entrar água de lastro. Cada vez que a água de lastro é colocada em um navio seres } \\
\text { vivos que vivem nessa água: algas, bactérias, plantas e ANIMAIS pequenos o } \\
\text { suficiente para serem sugados pelas bombas e transportados para dentro dos tanques } \\
\text { [estudante: o:.: que nem peixe] Alguns desses seres vivos podem morrer dentro do } \\
\text { próprio tanque de lastro devido as condições internas pouco favoráveis à sua } \\
\text { sobrevivência, mas alguns desses poucos seres vivos CONSEGUEM sobreviver a } \\
\text { longas viagens.”... tem animais que entram aqui no Brasil no tanque de lastro e vão } \\
\text { sobreviver até chegar lá na China... "E quando o navio para em um porto e seus } \\
\text { tanques são esvaziados, tais seres vivos são despejados na água” ... Fabrício... “ e em } \\
\text { um local diferente do que habitava, e onde talvez não existissem animais de sua } \\
\text { espécie anteriormente. Após despejados ao mar, muitos desses seres vivos morrem, } \\
\text { pois na maior parte das vezes, não encontra alimento e condições climáticas adequadas } \\
\text { para sobreviver.”... eu vou esperar vocês terminarem de conversar para continuar } \\
\text { porque não dá... "Após despejados ao mar muitos desses seres vivos morrem, pois na }\end{array}$ \\
\hline
\end{tabular}




\begin{tabular}{|c|c|}
\hline & $\begin{array}{l}\text { maior parte das vezes não encontram alimentos e condições climáticas adequadas para } \\
\text { sobreviver. Alguns ainda conseguem sobreviver, mas não encontram parceiros para se } \\
\text { reproduzirem. E isso acaba impedindo que a espécie desse ser vivo ocupe o novo } \\
\text { ambiente em que foi despejado. Porém alguns desses seres vivos, por sorte, chegam a } \\
\text { locais que possuem as condições climáticas ideias e bastante alimento e, o melhor, } \\
\text { nenhum predador.” ... o que é mesmo predador? hã? }\end{array}$ \\
\hline 72 & Estudante: (inaudível) ele pega o animal \\
\hline 73 & Professora: Ele pega o outro animal para quê? \\
\hline 74 & Estudantes: Comer... comer... \\
\hline 75 & $\begin{array}{l}\text { Professora: Para se alimentar, certo? tá.... então o que pode acontecer com esses } \\
\text { animais que estão no tanque de lastro? [estudantes: morrer] de repente aqui no Brasil } \\
\text { tem algum tipo de peixinho que não tem lá na China.... aí ele vai no tanque de lastro... } \\
\text { ele sobrevive lá no tanque... aí chega lá na China não tem o alimento que ele gosta de } \\
\text { comer e o que que vai acontecer com ele? }\end{array}$ \\
\hline 76 & Estudantes: Morrer \\
\hline 77 & $\begin{array}{l}\text { Professora: Ele vai morrer... ou vai outro tipo de animal marinho e vai o machinho lá } \\
\text { dentro... só que vai chegar lá na China e não tem também outro animal da mesma } \\
\text { espécie que a dele,.. não tem a fêmea... tem a comida que ele gosta de comer Talita... } \\
\text { mas não tem a fêmea para ele se reproduzir... só tem ele lá de machinho e conforme o } \\
\text { tempo vai passando o que é que vai acontecer? }\end{array}$ \\
\hline 78 & Estudantes: Morrer \\
\hline 79 & $\begin{array}{l}\text { Professora: Ele vai morrer... e sem a fêmea lá ele não vai poder se reproduzir, aí ele } \\
\text { não vai ter mais aquele bichinho vai morrer... mas também pode acontecer por } \\
\text { exemplo de vir algum tipo animal lá da China dentro do tanque de lastro aqui para o } \\
\text { Brasil e chegar aqui... encontrar alimento e vir com o macho e a fêmea... vem os dois... } \\
\text { o casalzinho.... eles vêm lá no tanque de lastro.. aí ele chega aqui no Brasil no mar do } \\
\text { Brasill e nenhum animal aqui é o predador desse animal... nenhum animal gosta } \\
\text { daquele bichinho... e o que vai acontecer? hã? }\end{array}$ \\
\hline 80 & Estudante: Vai morrer \\
\hline 81 & $\begin{array}{l}\text { Professora: Ele vai morrer??? presta atenção... veio o casalzinho do animal... o } \\
\text { casalzinho do bichinho veio lá da China... chegou no Brasil e adoraram o local para } \\
\text { morar porque tem tudo para eles comerem é tudo de bom e... melhor ainda nenhum } \\
\text { animal é predador dele nenhum animal gosta de se alimentar dele }\end{array}$ \\
\hline 82 & estudantes: Ahhhh \\
\hline 83 & Professora: O que é que vai \\
\hline 84 & Estudantes: Vai sobreviver \\
\hline 85 & $\begin{array}{l}\text { Professora: Vai sobreviver... e o que mais que vai acontecer? eles chegaram juntos... o } \\
\text { macho e a fêmea }\end{array}$ \\
\hline 86 & Fabrício: Vai poder se reproduzir \\
\hline 87 & $\begin{array}{l}\text { Professora: Vai poder se reproduzir... mas e aí... está lá os dois felizes da vida... se } \\
\text { reproduzindo... tiveram mais dois filhinhos... nasceu né? tiveram mais um casalzinho... } \\
\text { e aí? e vocês sabem né? que os animais não tem essa né? casam e ficam felizes para } \\
\text { sempre... não tem essa de irmão... de mãe não... todo mundo... é uma festa só... e aí o } \\
\text { que é que vai acontecer com esse tipo de animal? hã? vai continuar acontecendo o quê? }\end{array}$ \\
\hline 88 & Fabrício: Se reproduzindo \\
\hline 89 & $\begin{array}{l}\text { Professora: Vão continuar se reproduzindo e não tem predador para ele... ninguém } \\
\text { gosta daquele bichinho lá para se alimentar... nenhum outro animal se alimenta dele... e } \\
\text { aí? hã? }\end{array}$ \\
\hline
\end{tabular}




\begin{tabular}{|c|c|}
\hline 90 & Estudante: (inaudível) fica vivo \\
\hline 91 & Professora: Não entendi... hã? vai continuar vivo? e vai continuar acontecendo o quê? \\
\hline 92 & Maria: Vai tendo mais \\
\hline 93 & Professora: Vai tendo mais... e aí? \\
\hline 94 & $\begin{array}{l}\text { Estudantes: ((falas indiscriminadas . Todos falando ao mesmo tempo)) vai ficar o } \\
\text { casalizinho se reproduzindo }\end{array}$ \\
\hline 95 & $\begin{array}{l}\text { Professora: Vai continuar se reproduzindo e não tem predador e vai continuar se } \\
\text { reproduzindo }\end{array}$ \\
\hline 96 & Estudantes: (inaudível) envelhecer \\
\hline 97 & Professora: Hã? não entendi \\
\hline 98 & João: Vai ficar velho \\
\hline 99 & Professora: Mas vai acontecer o que João? \\
\hline 100 & João: Vai ter outros \\
\hline 101 & Professora: Vai ter outros... e aí? \\
\hline 102 & Estudantes: [falas ao mesmo tempo] \\
\hline 103 & $\begin{array}{l}\text { Professora: Ah... sim.. e aí esse tipo de animal vai aumentando aumentando } \\
\text { aumentando e aumentando... e isso pode ser um problema também... mas nós vamos } \\
\text { estudar na próxima aula... hoje o que é que a gente aprendeu? principalmente }\end{array}$ \\
\hline 104 & Estudante: as embarcações com tanque e reproduzindo \\
\hline 105 & Professora: Tanque de? \\
\hline 106 & Estudantes: Lastro \\
\hline 107 & Professora: Lastro... para que serve o tanque de lastro nas embarcações? \\
\hline 108 & Estudantes: Para sugar e por a água \\
\hline 109 & Professora: E porque tem que tirar a água e pôr a água? \\
\hline 110 & Maria: Por causa das embarcações... quando uma embarcação sai a agua entra. \\
\hline 111 & Professora: Se a embarcação sai a água entra? \\
\hline 112 & Estudante: e::: parabéns tá sabendo lagal ((um estudante aplaude e ri)) \\
\hline 113 & $\begin{array}{l}\text { Professora: O que sai? Do navio para entrar a água de lastro? é quando tira o quê da } \\
\text { embarcação? }\end{array}$ \\
\hline 114 & Estudante: As cargas \\
\hline 115 & $\begin{array}{l}\text { Professora: As cargas né? Se as cargas saem a água de lastro tem que entrar... e se a } \\
\text { carga entra na embarcação? }\end{array}$ \\
\hline 116 & Estudantes: Tira a água \\
\hline 117 & $\begin{array}{l}\text { Professora: A água tem que sair... né? certo... e quando essa água entra o que é que } \\
\text { pode entrar lá também? }\end{array}$ \\
\hline 118 & Estudantes: Animais \\
\hline 119 & $\begin{array}{l}\text { Professora: Animais e vegetais que tem lá... né? algas... que tem na vida marinha... né? } \\
\text { então por hoje é só! até a próxima }\end{array}$ \\
\hline
\end{tabular}




\section{APÊNDICE C - Transcrição da atividade 9 - Análise dos dados da tabela- 27/11/2012 - 45’10" de vídeo}

\begin{tabular}{|c|c|}
\hline 1 & Professora: Bom dia! \\
\hline 2 & Estudantes: Bom dia! \\
\hline 3 & $\begin{array}{l}\text { Professora: Bom... então pra quem não veio ontem né... nós fizemos uma atividade... um } \\
\text { jogo chamado presa e predador... tá? e enquanto brincava de "presa e predador... a } \\
\text { professora registrou as situações para cada grupo de seres vivos... em cada uma das } \\
\text { rodadas em uma tabela como esta... onde podemos ver a quantidade de plantas... } \\
\text { tapitis... jaguatiricas de cada rodada"... então... a cada rodada de jogo... né... quando } \\
\text { fazia a contagem... é Adriano... eu anotei todas as quantidades de seres vivos... né... que } \\
\text { ficavam ao final de cada rodada. e vocês têm a tabela aí que vocês preencheram... certo? }\end{array}$ \\
\hline 4 & Estudantes: Certo \\
\hline 5 & Professora: Tiveram quantas rodadas? \\
\hline 6 & Estudantes: sete... sete... sete. \\
\hline 7 & $\begin{array}{l}\text { Professora: sete né? aí vocês preencheram a tabela... agora... eu vou entregar umas } \\
\text { questões pra vocês... tá dizendo assim... agora... com SEUS COLEGAS discuta e } \\
\text { responda as questões ABAIXO e depois ESCREVA e DESENHE sobre suas } \\
\text { conclusões... né Fábio? o que é que vocês descobriram... né... que conclusão... o que que } \\
\text { vocês descobriram... o que acontece naquele jogo... e desenhar também... tá bom? O } \\
\text { desenho pode ser no caderno. }\end{array}$ \\
\hline 8 & Estudante: Professora... pode escrever aqui? \\
\hline 9 & $\begin{array}{l}\text { Professora: no caderno de projetos... as respostas só na folha... se couber o desenho aí na } \\
\text { folha... tudo bem... se não... faz no caderno de projetos... ((professora passa pelos grupos } \\
\text { entregando uma folha)) ÉMERSON! Vocês vão observar a tabela e responder as } \\
\text { perguntas que têm aí na folha... e vocês vão conversar com o colega... vocês estão em } \\
\text { grupo... mesmo quem não veio... vai poder responder porque tem a tabela aí... tem todos } \\
\text { os dados... e as perguntas é pra analisar a tabela... então... mesmo quem faltou... vai } \\
\text { conseguir analisar. Ariel... Ariel? }\end{array}$ \\
\hline 10 & Ariel: Que? \\
\hline 11 & $\begin{array}{l}\text { Professora: PODE COMEÇAR.... ((professora se dirige ao grupo 6)) Ariel... toma eu te } \\
\text { empresto uma borracha.. Agora... senta nessa cadeira e começa... }\end{array}$ \\
\hline 12 & $\begin{array}{l}\text { ((passam-se 1'18" em que observamos os estudantes conversarem nos grupos e } \\
\text { manipularem a folha recebida, fazendo algumas anotações)) }\end{array}$ \\
\hline 13 & $\begin{array}{l}\text { Professora: Ô FABRÍCIO... vem pra cá... por favor... o:.: só tem os dois aqui (( Fabrício } \\
\text { sai de um ponto não captado pela câmera e vai até o grupo } 1 \text {. Enquanto isso, a } \\
\text { professora vai até o grupo 6)) }\end{array}$ \\
\hline 14 & Professora: Nesse grupo aqui ninguém veio ontem? \\
\hline 15 & Estudante: o Diego veio ontem. \\
\hline 16 & $\begin{array}{l}\text { Professora: Você veio? mas aí... É SÓ LER AS PERGUNTAS E ANALISAR A } \\
\text { TABELA... PRIMEIRO QUEM NÃO VEIO... VAI PODER... VÊ AÍ O QUE } \\
\text { ACONTECEU... ENTENDEU? a Carolina não veio... mas ela também estava... ela já lê }\end{array}$ \\
\hline
\end{tabular}




\begin{tabular}{|c|c|}
\hline & a pergunta e vocês procuram na tabela o que foi que aconteceu... cadê a sua tabela? \\
\hline 17 & Estudante Professora... é pra colocar o nome? ou é pra... pra... \\
\hline 18 & Professora: Colocar o nome aonde? \\
\hline 19 & Estudante: Aqui. \\
\hline 20 & $\begin{array}{l}\text { Professora: É... o nome ((professora vai até o grupo } 2)) \text { a Irene tava... Patrícia tava e } \\
\text { Israel e Joana também... Renan não consta aqui... na tabela... então... mas você vai lê... e } \\
\text { aí ele vai olhar... } 1^{\text {a }} \text { rodada... o que que aconteceu? lê a pergunta... e você tem que } \\
\text { analisar aqui... o::: aqui primeiro o::: ((professora aponta na folha do estudante)) planta... } \\
\text { tapiti e jaguatirica }\end{array}$ \\
\hline 21 & $\begin{array}{l}\text { Professora: ((professora caminha até o grupo } 6 \text { e observa o grupo trabalhar por alguns } \\
\text { instantes)) Lê em voz alta... aí todo mundo ouve... e vai procurando... Ariel... a primeira } \\
\text { rodada é aqui o::: e a segunda rodada é aqui... não é de assim que cê vai olhar... é de } \\
\text { assim ((professora faz um movimento com a mão indicando que o estudante deve olhar } \\
\text { as linhas e não as colunas da tabela)) }\end{array}$ \\
\hline 22 & Manoel: Eu sei a primeira (inaudível) \\
\hline 23 & Estudante: Onde (inaudível) \\
\hline 24 & $\begin{array}{l}\text { Professora: Isso! Pega a tabela... “que rodada... o número de plantas foi maior?” então... } \\
\text { tem que escrever isso aí... Ariel... olha lá na... na tabela... em qual rodada o número de } \\
\text { plantas foi maior? }\end{array}$ \\
\hline 25 & Ariel: Aqui? ((Ariel aponta para sua folha)) \\
\hline 26 & $\begin{array}{l}\text { Professora: Não... olha de novo... “em qual rodada... o número de plantas foi maior?" } \\
\text { Aqui foi a primeira rodada... segunda... terceira... quarta... quinta... sexta e sétima } \\
\text { ((professora aponta para as linhas da tabela)) em qual rodada... teve mais plantas? não é } \\
\text { pra escrever... olha aqui... planta... não precisa anotar aqui... espera... é pra analisar... tá } \\
\text { perguntando em qual rodada... aqui é planta... aqui é o tapiti e aqui é a jaguatirica... aí... } \\
\text { você vai olhar assim... quem foram os seres vivos da da brincadeira... mas a rodada é } \\
\text { vertical }\end{array}$ \\
\hline 27 & Estudante: Professora... PROFESSORA ((um estudante no grupo 3 chama a professora)) \\
\hline 28 & $\begin{array}{l}\text { Professora: E aí... em qual rodada... o número de plantas foi maior... ((Ariel aponta em } \\
\text { sua ficha)) i:::sso }\end{array}$ \\
\hline 29 & Lígia: Na quarta... na quarta \\
\hline 30 & Manoel: (inaudível) \\
\hline 31 & Professora: Então gente... tem que vê isso... assim ela falô... repete pra ele... \\
\hline 32 & Lígia: Na quarta e na quinta \\
\hline 33 & Professora: Na quarta e na quinta \\
\hline 34 & Rosa: professora ((professora vai até o grupo 5)) \\
\hline 35 & $\begin{array}{l}\text { Professora: Assim... “à medida que o número de tapitis AUMENTA... o número de } \\
\text { plantas aumenta ou diminui?” quando tem mais de tapiti... a planta aumenta ou } \\
\text { diminui... o número de plantas... quando aumenta o número de tapitis. }\end{array}$ \\
\hline 36 & Suzana: Diminui \\
\hline 37 & $\begin{array}{l}\text { Professora: Explique por que isso acontece... por que será que tem hora que aumenta o } \\
\text { número de plantas e hora que diminui o número de tapiti... olha lá a tabela... tem que ver } \\
\text { a tabela... a quantidade de tapitis e a quantidade de plantas }\end{array}$ \\
\hline
\end{tabular}




\begin{tabular}{|c|c|}
\hline 38 & Suzana: Não sei ver... ((professora se aproxima da estudante)) \\
\hline 39 & $\begin{array}{l}\text { Professora: Quando tem mais tapiti... quando tem mais planta... olha lá... a quantidade } \\
\text { de planta... tem mais ou tem menos tapiti? Diminui ou aumenta? }\end{array}$ \\
\hline 40 & Suzana: Aumenta \\
\hline 41 & Professora: Por que será? pensa no jogo... na brincadeira lá... por que que acontece isso? \\
\hline 42 & Suzana: ((Suzana aponta para a tabela na lousa)) Porque o tapiti pode comer mais planta \\
\hline 43 & $\begin{array}{l}\text { Professora: ((professora vai até um grupo que não é capturado pela câmera)) } \\
\text { CAROLINA... é o grupo... é pra fazer junto }\end{array}$ \\
\hline 44 & Carolina: o:::professora... o Rodrigo não quer fazer nada.... não quer fazer NADA \\
\hline 45 & PROFESSORA: Vai Rodrigo... tem que responder as perguntas... senta direitinho \\
\hline 46 & Ariel: Professora? \\
\hline 47 & Professora Oi? \\
\hline 48 & Ariel: A segunda... número 4 (inaudível) terceira... a primeira \\
\hline 49 & Professora: Olha lá... o que tem planta... em qual rodada que foi menor? \\
\hline 50 & Ariel: A Nove e oito... QUATRO... quatro... é a três \\
\hline 51 & Professora: Não é três... é na TERCEIRA \\
\hline 52 & $\begin{array}{l}\text { Estudantes: Onze... primeira... a um... sete... onze... embaixo... aqui o::: tem que } \\
\text { explicar... Fábio:: o número de plantas((ao fundo, ouvimos fragmentos das hipóteses dos } \\
\text { estudantes e a professora continua observando o trabalho do grupo 6)) }\end{array}$ \\
\hline 53 & Professora: Isso::: que rodada... o número de plantas foi menor? \\
\hline 54 & Ariel: Menor? \\
\hline 55 & Talita: É a três \\
\hline 56 & $\begin{array}{l}\text { Professora: Olha lá... Ariel... olha aqui... o::: quantas plantas têm? qual rodada foi } \\
\text { menor... tem que ver a quantidade ARIEL }\end{array}$ \\
\hline 57 & Estudantes: Prô? ((professora vai até o grupo 5 que a chama)) \\
\hline 58 & $\begin{array}{l}\text { Professora: "Além da disponibilidade de alimento... que outro fator influenciou o } \\
\text { crescimento da população de tapitis"... é assim... ele precisa de planta pra ele }\end{array}$ \\
\hline 59 & Suzana: Sobreviver \\
\hline 60 & $\begin{array}{l}\text { Professora: Sobreviver né? Então ...qual o fator que ajudou a aumentar a população de } \\
\text { tapiti... por que quem é que caçava ele? }\end{array}$ \\
\hline 61 & Suzana: A jaguatirica \\
\hline 62 & Professora: E se aumentou a população dele... o que que foi que aconteceu? \\
\hline 63 & Suzana: Comeu planta? \\
\hline 64 & $\begin{array}{l}\text { Professora: Não... se aumentou? ele comeu a planta... e aí... aumentou o número de } \\
\text { tapitis... por que que aconteceu isso? }\end{array}$ \\
\hline 65 & Suzana: Por causa que comeu planta \\
\hline 66 & $\begin{array}{l}\text { Professora: Sim.... mas... não tinha alguém que também caçava ele? ((Suzana balança a } \\
\text { cabeça afirmativamente)) se aumentou o número de tapitis... }\end{array}$ \\
\hline 67 & Rosa: Foi a jaguatirica \\
\hline
\end{tabular}


68 Professora: Sim... se a jaguatirica tivesse pego o tapiti... o que tinha acontecido? teria aumentado a população dele?

69 Suzana: Não

70 Professora: Então... se aumentou a população... o que que aconteceu?

71 Rosa: Jaguatirica

72 Professora: Sim... mas por que que aumentou?

73 Rosa: Por que sobreviveu

74 Professora: Mas por que que ele sobreviveu? Além de comer a planta

75 Rosa: A jaguatirica não pegou ele

76 Professora: Porque será que a jaguatirica não pegou ele... é isso mesmo... pode responder ((professora vai até o grupo dois))

77 Professora: Em que roda... o::: em que rodada o número de plantas foi menor? em que rodada foi menor? ((professora aponta para a tabela da lousa)) onde tinha menos planta lá? Qual rodada?

78 Marco: Na sete

79 Professora: Na sétima... isso.

80 Professora: Em que rodada começou com o maior número de tapitis?

81 Marco: DezesSEI

82 Professora: Terceira... olha aqui "quantas plantas havia nessa rodada?" quando tinha dezesSEI tapitis... tinham quantas plantas?

83 ((professora continua circulando pelas carteiras e ouvimos fragmentos das hipóteses dos estudantes e das perguntas da professora. No total, os estudantes trabalham nos grupos por cerca de 16 minutos))

84 Professora: Bom, então vamo lá, o::.. então... vamo analisar a tabela junto agora... vão ver aí a resposta que vocês colocaram

85 Estudante: EBA

86 Professora: Vamos ver se é isso mesmo... todo mundo concorda.. tá?

87 Professora: "Um...em que rodada o número de plantas foi maior?"

88 Estudantes: Onze

89 Professora Em que RODADA, o número de plantas foi maior?

90 Estudantes: Onze

91 Rosa: Quarta e a quinta

92 Professora: Quarta e quinta né? por quê?

93 Estudante: Os dois têm onze

94 Estudante: A mesma quantidade

95 Professora: Os dois tiveram a mesma quantidade... a quarta e a quinta rodada, o número de plantas foi maior

96 Estudantes: A sete

97 Professora: Em que rodada o número de plantas foi menor? 


\begin{tabular}{|c|c|}
\hline 98 & Estudantes: Sétima. \\
\hline 99 & Professora: Quantas plantas tiveram... BETÂNIA... na sétima rodada? \\
\hline 100 & Estudantes: Uma \\
\hline 101 & $\begin{array}{l}\text { Professora: Uma.... né Maria ... "terceira... que rodada começou com o maior número de } \\
\text { tapitis?" }\end{array}$ \\
\hline 102 & Estudantes: Três \\
\hline 103 & $\begin{array}{l}\text { Professora: Terceira::: gente... ali tá os números ordinais primeiro... segundo... terceiro... } \\
\text { quarto... quinto... sexto... sétimo... }\end{array}$ \\
\hline 104 & Estudante: Acertei \\
\hline 105 & Professora: Em que rodada começou com maior número de tapitis? \\
\hline 106 & Estudantes: A terceira \\
\hline 107 & Professora: A terceira... com quantos? \\
\hline 108 & Estudante: DezesSEI \\
\hline 109 & $\begin{array}{l}\text { Professora: DezesSEI “quantas plantas havia nessa rodada"... quando tinha dezesSEI } \\
\text { tapitis... quantas plantas tinham? }\end{array}$ \\
\hline 110 & Estudante: Quatro... \\
\hline 111 & Professora: Quando tinha dezesSEI tapitis na terceira rodada... quantas plantas tinha? \\
\hline 112 & Estudante: Quatro... \\
\hline 113 & $\begin{array}{l}\text { Professora: Quatro é:.: “à medida que o número de tapitis aumenta... o número de } \\
\text { plantas aumenta ou diminui?" Quando aumenta o número de tapitis... o número de } \\
\text { plantas aumenta ou diminui? Vamos ver aqui então ((professora aponta a linha e a } \\
\text { coluna que devem ser observadas na tabela da lousa)) quando aumenta o número de } \\
\text { tapitis... onde mais aumentou aqui? }\end{array}$ \\
\hline 114 & Estudantes: DezesSEI \\
\hline 115 & Professora: O número de plantas aumentou ou diminuiu? \\
\hline 116 & Estudantes: Diminui \\
\hline 117 & Estudantes: Aumentou \\
\hline 118 & $\begin{array}{l}\text { Professora: AUMENTOU? ((professora aponta para a linha da tabela)) tinha dezesSEI } \\
\text { tapitis? [Estudantes: diminuiu] e planta tinha quatro... aumentou o tapiti... e a planta? } \\
\text { aumentou ou diminuiu? }\end{array}$ \\
\hline 119 & Estudantes: Diminuiu...diminuiu \\
\hline 120 & Professora: Por que que aumentou o número de tapitis se diminuiu o número de plantas? \\
\hline 121 & Suzana Porque os tapitis comeram as plantas. \\
\hline 122 & $\begin{array}{l}\text { Professora: Porque os tapitis comeram as plantas... se os tapitis comeram as plantas... } \\
\text { diminuiu o número de? }\end{array}$ \\
\hline 123 & Estudantes: Plantas... \\
\hline 124 & $\begin{array}{l}\text { Professora: Além da disponibilidade de alimentos... quer dizer... além de ter plantinhas } \\
\text { pra eles comerem... que outro fator influenciou no crescimento da população do tapiti? } \\
\text { Por que que aqui aumentou o número de tapitis? }\end{array}$ \\
\hline 125 & Fabrício: Porque ele comeu o... as plantas e o::: e virou as plantas virou tapiti. \\
\hline
\end{tabular}




\begin{tabular}{|c|c|}
\hline 126 & $\begin{array}{l}\text { Professora: E virou tapiti... certo. E por que que eles conseguiram ficar assim... vários } \\
\text { tapitis? }\end{array}$ \\
\hline 127 & Ariel: Porque eles comeram as plantas \\
\hline 128 & $\begin{array}{l}\text { Professora: Sim... mesmo depois que eles comeram as plantas... beleza... aí tinha lá... } \\
\text { começou é: a outra rodada... tinham vários... }\end{array}$ \\
\hline 139 & Fabrício: Jaguatirica não pegou o tapiti \\
\hline 130 & $\begin{array}{l}\text { Professora: Ah... ta::: porque a jaguatirica não tinha pego o tapiti... porque se tivesse } \\
\text { pego não teria aumentado... certo? }\end{array}$ \\
\hline 131 & Estudantes: Professora... acabei \\
\hline 132 & $\begin{array}{l}\text { Professora: Na sétima agora... o:.: "houve variações no tamanho da população de } \\
\text { jaguatirica?" mudou aqui o número de Jaguatirica? Se aumentou...diminuiu... isso } \\
\text { aconteceu? ou o número de jaguatirica desse é sempre igual... sempre o mesmo? }\end{array}$ \\
\hline 133 & Estudantes: Não... baixa e aumenta \\
\hline 134 & $\begin{array}{l}\text { Professora: Abaixa e aumenta... diminui e aumenta... né? em que rodada o número } \\
\text { ARIEL em que rodada o número de jaguatirica foi mais baixo? }\end{array}$ \\
\hline 135 & Fabrício: Ali sei... cinco... \\
\hline 136 & $\begin{array}{l}\text { Professora: Mais BAIXO... em que rodada o número [Estudante: cinco] de jaguatirica } \\
\text { foi mais baixo? }\end{array}$ \\
\hline 137 & Estudantes: A três... a cinco... a três... a cinco \\
\hline 138 & $\begin{array}{l}\text { Professora: A terceira e a::: [Estudantes: a quinta] a quinta... a terceira e a quinta... } \\
\text { ARIEL... o número de jaguatirica foi menor... DIEGO... "nessa rodada... a população de } \\
\text { tapitis estava aumentando... diminuindo ou tinha alcançado o seu número máximo?" }\end{array}$ \\
\hline 139 & Estudantes: Máximo \\
\hline 140 & $\begin{array}{l}\text { Professora: Quando diminuiu o número de jaguatirica é: a população de tapiti aumentou } \\
\text { ou diminuiu? }\end{array}$ \\
\hline 141 & Estudantes: Aumentou \\
\hline 142 & Professora: E a população de plantas? \\
\hline 143 & Estudantes: Abaix ou \\
\hline 144 & $\begin{array}{l}\text { Professora: Uma vez abaixou né? ((professora aponta às respectivas linhas da tabela)) } \\
\text {...na outra vez... [Estudantes: aumentou...] aumentou... porque que aqui o:.: ((professora } \\
\text { aponta a terceira linha)) tinha pouca jaguatirica... bastante tapiti e pouca planta? o que } \\
\text { que aconteceu aqui pra ter pouca jaguatirica? }\end{array}$ \\
\hline 145 & Fabrício: A jaguatirica não pegar ninguém \\
\hline 146 & Professora: A jaguatirica não tinha pego nenhum tapiti \\
\hline 147 & Fabrício: O tapiti pega as as: plantas e::: \\
\hline 148 & $\begin{array}{l}\text { Professora: Entendi... a jaguatirica não conseguiu... a maioria não conseguiu pegar o } \\
\text { tapiti e o tapiti não comeu muita planta e aumen... comeu a planta.... diminuiu o tama... a } \\
\text { quantidade de plantas né... aumentou o número de tapiti... diminuiu o número de } \\
\text { jaguatirica... e na quinta rodada... aqui foi diferente... Tinha pouca jaguatirica... mas } \\
\text { diminuiu o número de tapiti aqui também em relação à planta... o que foi que aconteceu } \\
\text { aqui? }\end{array}$ \\
\hline 149 & Fabrício: A::: ((Fabrício vai até a lousa)) o tapiti não pegou a planta... e virou a planta \\
\hline
\end{tabular}




\begin{tabular}{|c|c|}
\hline $150-$ & Professora: E agora... só não entendi porque o tapiti não conseguiu pegar a planta? \\
\hline 151 & Fabrício: Por que o outro pegou \\
\hline 152 & $\begin{array}{l}\text { Professora: A:.: porque o outro pegou... chegou primeiro né? "em que rodada... o } \\
\text { número de jaguatiricas foi maior?" }\end{array}$ \\
\hline 153 & Estudantes: A sétima... \\
\hline 154 & $\begin{array}{l}\text { Professora: "Relacione esse acontecimento ao crescimento das populações de tapitis e } \\
\text { plantas"... então aqui... por que que tinha quinze jaguatiricas... sete tapitis e só uma } \\
\text { planta? }\end{array}$ \\
\hline 155 & Lígia: PROFESSORA ESTÁ EM QUE NÚMERO... SEXTA \\
\hline 156 & $\begin{array}{l}\text { Professora: A sétima... a OITAVA... o que aconteceu aqui nessa rodada? ((Fabrício vai à } \\
\text { lousa)) }\end{array}$ \\
\hline 157 & $\begin{array}{l}\text { Fabrício: Porque... porque o tapiti comeu mais... o tapiti tinha... porque a jaguatirica } \\
\text { pegou o tapiti }\end{array}$ \\
\hline 158 & Professora: Porque a jaguatirica pegou o tapiti né? E o tapiti pegou as? \\
\hline 159 & Estudantes: Plantas \\
\hline 160 & $\begin{array}{l}\text { Professora: Certo.... aqui só tinha uma planta... se fosse lá um tapiti e comesse essa } \\
\text { planta e num ficasse nenhuma planta... e ainda ficassem sete tapitis... o que que ia } \\
\text { acontecer? }\end{array}$ \\
\hline 161 & Fabrício: A jaguatirica tinha pegado os tapitis... só que \\
\hline 162 & Professora: Tá... mais antes da: da jaguatirica pegar os tapitis... tava lá... \\
\hline 163 & Fabrício: Sim... eu sei \\
\hline 164 & $\begin{array}{l}\text { Professora: Os tapitis têm... por exemplo... acabou... chegou o primeiro tapiti lá e comeu } \\
\text { a planta... ainda ficaram SEI tapitis sem comer planta FÁBIO... acabou a planta... e aí... } \\
\text { o que será que ia acontecer com esses SEI tapitis... esquece a jaguatirica por enquanto... } \\
\text { o que que ia acontecer com esses SEI tapitis... se não tivesse nenhuma planta? }\end{array}$ \\
\hline 165 & Estudantes: Ia virar planta \\
\hline 166 & $\begin{array}{l}\text { Professora: não.... mas fora do jogo... pensa lá... se fosse lá... no meio do mato... o } \\
\text { tapiti... um de sete... um foi lá e comeu a planta... SEI ficaram sem comer... que que ia } \\
\text { acontecer com esse tapiti? }\end{array}$ \\
\hline 167 & Rosa: Ele ia morre::: \\
\hline 168 & Professora: Escuta... escuta... Rosa fala. \\
\hline 169 & Rosa: Ele ia morrer \\
\hline 170 & Professora: Ele ia morrer... por que? \\
\hline 171 & Rosa: Porque [Estudante: as Jaguatiricas] ele não ia ter o que comer \\
\hline 172 & $\begin{array}{l}\text { Professora: Porque não ia ter comida pra ele... ele se alimenta da planta e não tem } \\
\text { planta... o tapiti ia morrer... e se o tapiti morresse? }\end{array}$ \\
\hline 173 & Fabrício: A jaguatirica fica sem comer e morresse. \\
\hline 174 & Professora: A jaguatirica ia ficar sem comer e ia? \\
\hline 175 & Estudantes: Morrer \\
\hline 176 & $\begin{array}{l}\text { Professora: Morrer também... certo? e por que que quando os tapitis comiam a planta... } \\
\text { aumentava o número de tapitis? }\end{array}$ \\
\hline
\end{tabular}




\begin{tabular}{|c|c|}
\hline 177 & Estudantes: Eles iam engordar mais... \\
\hline 178 & Fabrício: Por que eles... eles... se ele comesse eles ninguém (inaudível \\
\hline 179 & $\begin{array}{l}\text { Professora: Sim... mas assim... pensando no bichinho de verdade... por que será que } \\
\text { aumenta o número de tapiti quando ele se alimenta? }\end{array}$ \\
\hline 180 & Irene: porque nasce mais tapiti \\
\hline 181 & $\begin{array}{l}\text { Professora: Porque nasce mais tapiti... a::: porque ele se alimenta... ele fica forte... aí a } \\
\text { tapiti fêmea vai lá... namora o tapiti macho né? e aí o que que acontece? o que acontece? }\end{array}$ \\
\hline 182 & Irene: Aí tem filhote... \\
\hline 183 & $\begin{array}{l}\text { Professora: Aí vai acontecer o quê? vai aumentar né ARIEL a população de tapitis... Eu } \\
\text { vou entregar um textinho agora pra gente ler... presta atenção que cada um vai ler um } \\
\text { pedacinho pra mim. Eu vou pedir pra cada um ler um pedacinho... }\end{array}$ \\
\hline 184 & Estudante: Faltou fazer o desenho \\
\hline 185 & Professora: A:::é faltou o desenho... mas vocês já fazem. \\
\hline 186 & Fabrício: Eu quero lê. \\
\hline 187 & Professora: Quem que quer ler? o Fabrício quer lê \\
\hline 188 & $\begin{array}{l}\text { Rosa: Eu também... eu quero ler ((Rosa está com a mão levantada, mas ao fundo } \\
\text { escutamos outros estudantes dizendo que também quer ler)) }\end{array}$ \\
\hline 189 & Professora: Tá eu vou pedir pra cada um ler um pedacinho... tá? \\
\hline 190 & Estudantes: Vou ler um maior... tá bom? vou ler... quero ler \\
\hline 191 & $\begin{array}{l}\text { Professora: Ô terceiro ano..., parô... [Lígia: Prô eu quero ler] pera aí... o Fabrício vai } \\
\text { começar... Acompanhe aí na folhinha... bem alto Fabrício PSIU }\end{array}$ \\
\hline 192 & Estudante: Calem a boca \\
\hline 193 & Professora: Adriano... Adriano... com a mente e os olhos... \\
\hline 194 & Fabrício: "Entendendo" (inaudível) \\
\hline 195 & Professora: MENINAS bem alto Fabrício \\
\hline 196 & Estudante: Não tô ouvindo nada. \\
\hline 197 & $\begin{array}{l}\text { Fabrício: Tá surda hein "AGORA que já brin... camos de pre...presa e predador e que já } \\
\text { con...versamos sobre essa brincadeira, vamos entender, entender um pouco mais sobre } \\
\text { a... com" }\end{array}$ \\
\hline 198 & Estudante: Acontecimento \\
\hline 199 & Fabrício: "O que aconteceu na nossa representação" \\
\hline 200 & $\begin{array}{l}\text { Professora: É uma pergunta o:.: "vamos entender um pouco mais sobre o que aconteceu } \\
\text { na nossa representação?" a Rosa vai continuar tá... CLÁUDIA... bem alto }\end{array}$ \\
\hline 201 & Rosa: "Durante o jogo em cada uma das eta... etapas a planta... que per...per" \\
\hline 202 & Professora: Permaneciam ((alguns estudantes riem)) \\
\hline 203 & $\begin{array}{l}\text { Rosa: "Em seus lugares e os tapitis tentavam se alimentar delas... e os tapitis precisavam } \\
\text { ser espertos pois em nossa mata além das plantas e de seus colegas tapitis (inaudível) } \\
\text { velozes e ferozes jaguatiricas que que desejavam também se alimentar e sua presa eram } \\
\text { os tapitis" }\end{array}$ \\
\hline 204 & Professora: Isso... Carolina... continua PSIU \\
\hline
\end{tabular}




\begin{tabular}{|c|c|}
\hline 205 & Carolina: "O que aconte (inaudível)" \\
\hline 206 & Estudante: Mais alto \\
\hline 207 & Professora: Não... ao término... é embaixo dos tapitis aqui o::: \\
\hline 208 & Estudante: Depois eu \\
\hline 209 & Professora: Pera aí que a Carolina tá lendo \\
\hline 210 & Carolina: (inaudível) \\
\hline 211 & Estudante: Lê alto \\
\hline 212 & Professora: PSIU a Carolina tá lendo \\
\hline 213 & $\begin{array}{l}\text { Carolina: "Tapiti já conseguia conseguia se ALIMENTAR e::: continuava tapiti na } \\
\text { rodada seguinte a planta da qual ele havia se alimentado também voltava na próxima } \\
\text { rodada como tapiti o mesmo acontecia no caso da ja... gua... [Estudante: } \\
\text { JAGUATIRICA] se::: [Professora: se alimentasse] na rodada seguinte continuaria a ser } \\
\text { jaguatirica }\end{array}$ \\
\hline 214 & $\begin{array}{l}\text { Professora: "Na rodada seguinte continuaria a ser jaguatirica... sua presa... ou seja... o } \\
\text { tapiti do qual ela teria se alimentado la... na rodada seguinte continuaria a ser } \\
\text { jaguatirica... sua presa... ou seja... tapiti do qual havia se alimentado... também seria } \\
\text { jaguatirica na rodada seguinte" vai }\end{array}$ \\
\hline 215 & Rosa: (inaudível) \\
\hline 216 & Professora: "E o que acontecia" \\
\hline 217 & Rosa: “Aos tapitis e jaguatiricas que não conseguissem se alimentar em uma rodada?” \\
\hline 218 & Estudantes: não dá para ouvir nada \\
\hline 219 & $\begin{array}{l}\text { Rosa: "Isso acontecia porque os animais que não conseguem alimento morrem de } \\
\text { fome... seus corpos são transformados em nutrientes }\end{array}$ \\
\hline 220 & $\begin{array}{l}\text { Professora: Isso foi o que o Fabrício disse que o animal que não se alimenta ele morre } \\
\text { né? e aí ele vira planta de novo porque ele vai virar o:.: nutriente pra terra lá né e aí } \\
\text { nasce uma outra plantinha naquele lugar "os tapitis e jaguatiricas que conseguiam } \\
\text { alimento CONTINUAVAM na rodada seguinte... respectivamente... como tapitis e } \\
\text { jaguatiricas porque haviam conseguido alimento e assim sobreviveram... todos os seres } \\
\text { vivos precisam de alimento para que se mantenham saudáveis e se reproduzam... } \\
\text { garantindo novos indivíduos para geração seguinte e é por esse motivo que as plantas e } \\
\text { os tapitis fossem capturados pelo seu predador... voltavam na rodada seguinte como ser } \\
\text { vivo da mesma espécie de seu predador... ou seja... as plantas que foram capturadas } \\
\text { voltam como tapitis... os tapitis capturados voltam como jaguatiricas... isso acontecia } \\
\text { porque quando o ser vivo serve de alimento para o outro as substâncias que formam o } \\
\text { seu corpo passam a fazer parte desse outro ser que o devorou" então quando... o tapiti } \\
\text { comia a plantinha a plantinha deixava de ser planta e passava pro organismo do tapiti } \\
\text { então ela se transformava em tapiti também... né? enquanto a jaguatirica se alimentava } \\
\text { do tapiti... o tapiti também virava... }\end{array}$ \\
\hline 221 & Estudante: $\mathrm{O}$ tapiti virava planta \\
\hline 222 & Professora: Quando a jaguatirica se alimentava do tapiti... o tapiti virava o quê? \\
\hline 223 & Estudantes: Tapiti \\
\hline 224 & Estudante: jaguatirica \\
\hline
\end{tabular}




\begin{tabular}{|c|c|}
\hline 225 & Professora: Jaguatirica... por quê? \\
\hline 226 & Estudantes: Ele vai ser comido \\
\hline 227 & Professora: Um de cada vez. \\
\hline 228 & Estudante: Ele vai ser comido \\
\hline 229 & $\begin{array}{l}\text { Professora: Vai ficar mais forte né? vai virar o alimento... tapiti vira alimento no } \\
\text { organismo dele... }\end{array}$ \\
\hline 230 & Fabrício: Igual o tapiti que come planta (inaudível) \\
\hline 231 & $\begin{array}{l}\text { Professora: Isso... Ele se reproduz quem mais quer falar? então... quando o... a planta de } \\
\text { um lugar acaba... o que acontece? }\end{array}$ \\
\hline 232 & Estudantes: O tapiti morre \\
\hline 233 & $\begin{array}{l}\text { Professora: O tapiti ou os animais... né? que se alimentam de plantas... né? vão morrer... } \\
\text { se faltar alimento, né, eles vão morrer... então agora... só falta vocês fazerem o } \\
\text { desenho... pode pegar a folhinha que tiver espaço... no caderno também... no caderno de } \\
\text { projeto }\end{array}$ \\
\hline 234 & Estudante: Desenho? \\
\hline 235 & $\begin{array}{l}\text { Professora: É... da conclusão aí que a gente acabou de falar... pode ser na folhinha da } \\
\text { tabela... o::: a folhinha da tabela... pera aí... dá licença ((professora pega a folha de } \\
\text { Ariel)) folhinha da tabela tem um espacinho maior embaixo }\end{array}$ \\
\hline 236 & Estudante: Professora... vai ter que recortar? \\
\hline 237 & Professora: Não... pode fazer embaixo... façam embaixo da tabela o desenho \\
\hline 238 & Estudantes: Você vai fazer o desenho (inaudível) vou fazer no caderno \\
\hline 239 & $\begin{array}{l}\text { Professora: Pra quem faltou ontem... olha, eu esqueci de falar que o tapiti é um tipo... é } \\
\text { um coelho tá? tapiti é um coelho e a jaguatirica é uma onça entendeu? }\end{array}$ \\
\hline 240 & Rosa: E a planta é planta \\
\hline 241 & $\begin{array}{l}\text { Professora: Planta é planta né... Rosa? ((Ariel se aproxima da professora e parece } \\
\text { perguntar algo)) jaguatirica é uma onça... tapiti é um coelho tá? o tapiti come a planta, a } \\
\text { jaguatirica come o tapiti }\end{array}$ \\
\hline 242 & Rosa: Não é para fazer isso.... Carolina... NÃO... Pro::: a Carolina vai fazer no caderno \\
\hline 243 & $\begin{array}{l}\text { Professora: Então terceiro ano... OLHA amanhã a gente::: vai encerrar o projeto de } \\
\text { experimentação científica. }\end{array}$ \\
\hline 244 & Estudantes A::: \\
\hline 245 & Professora ESTE ANO então não faltem amanhã tá? até a próxima aula então \\
\hline
\end{tabular}




\section{ANEXO A - Orientações para a resolução da atividade "A travessia do rio"7}

O desafio desta atividade só é solucionado corretamente quando se admite a possibilidade de o barco fazer várias viagens entre uma margem e outra.

Primeira viagem: o barco vai de uma margem a outra levando os homens de 60 e $65 \mathrm{~kg}$. Peso total na viagem: $125 \mathrm{~kg}$.

Segunda viagem: o barco volta para a outra margem com um dos homens (qualquer um, seja o de 60 ou o de $65 \mathrm{~kg}$ ). Vamos considerar que o homem que ficou na margem foi o de $60 \mathrm{~kg}$ e o que voltou com o barco foi o de $65 \mathrm{~kg}$. Peso total na viagem: $65 \mathrm{~kg}$.

Terceira viagem: o barco vai para a outra margem levando o homem de $80 \mathrm{~kg}$. Peso total na viagem: $80 \mathrm{~kg}$.

Quarta viagem: o barco volta com o homem de $60 \mathrm{~kg}$. Peso total na viagem: $60 \mathrm{~kg}$.

Quinta e última viagem: o barco vai para a outra margem levando os homens de 60 e $65 \mathrm{~kg}$.

Peso total na viagem: $125 \mathrm{~kg}$.

\footnotetext{
${ }^{7}$ Fonte: Texto retirado do livro Investigar e aprender: ciências, $4^{\circ}$ ano (CARVALHO et al, 2011b).
} 


\section{ANEXO B - Texto "Mantendo embarcações na água" para realização da sexta atividade $^{8}$}

\section{MANTENDO EMBARCAÇÕES NA ÁGUA}

Você acabou de ver que as embarcações podem ser utilizadas como meio de transporte tanto para cargas em geral quanto para passageiros. O tamanho das embarcações pode variar muito e, por isso, elas conseguem transportar muita ou pouca carga.

A capacidade de carga de uma embarcação merece sempre muita atenção, pois o excesso de carga pode implicar seu afundamento devido ao grande peso. A falta de carga também pode resultar em problema, já que a embarcação fica instável, ou seja, não se mantém equilibrada sobre a água e pode tombar.

Para evitar que as embarcações tenham o problema da falta de estabilidade, elas são providas de lastro.

O lastro das embarcações normalmente é feito com água retirada do mar ou do rio onde elas se encontram: bombas colocam e retiram água dos tanques dos navios garantindo estabilidade para que possam seguir viagem.

Quando a carga é retirada da embarcação, seu peso fica reduzido e ela fica instável, isto é, com facilidade de tombar. Assim, para manter a embarcação equilibrada, as bombas colocam água nos tanques para que ela continue estável sobre a água.

O inverso acontece quando a carga é colocada na embarcação. Seu peso fica maior e, se a carga máxima for excedida, a embarcação pode afundar.

Assim, a água do lastro é retirada para que a embarcação não fique muito pesada e afunde.

\footnotetext{
${ }^{8}$ Fonte: Texto e imagens retirados do livro Investigar e aprender: ciências, $4^{\circ}$ ano (CARVALHO et al, 2011a)
} 
ANEXO C - Imagens para realização da sexta atividade9

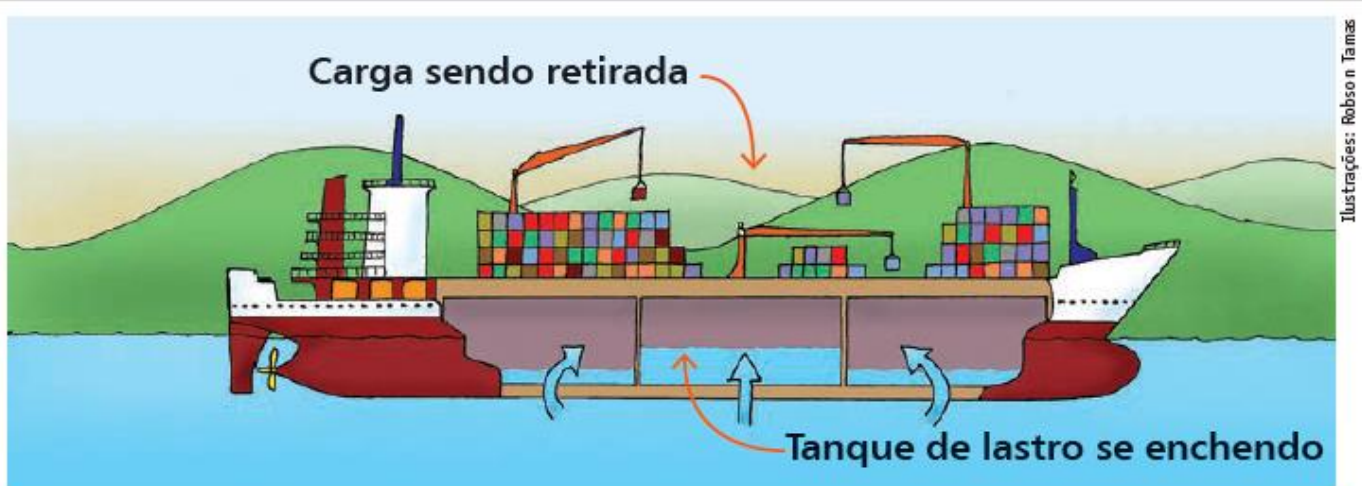

No porto de origem, retirando a carga, carregando água de lastro.

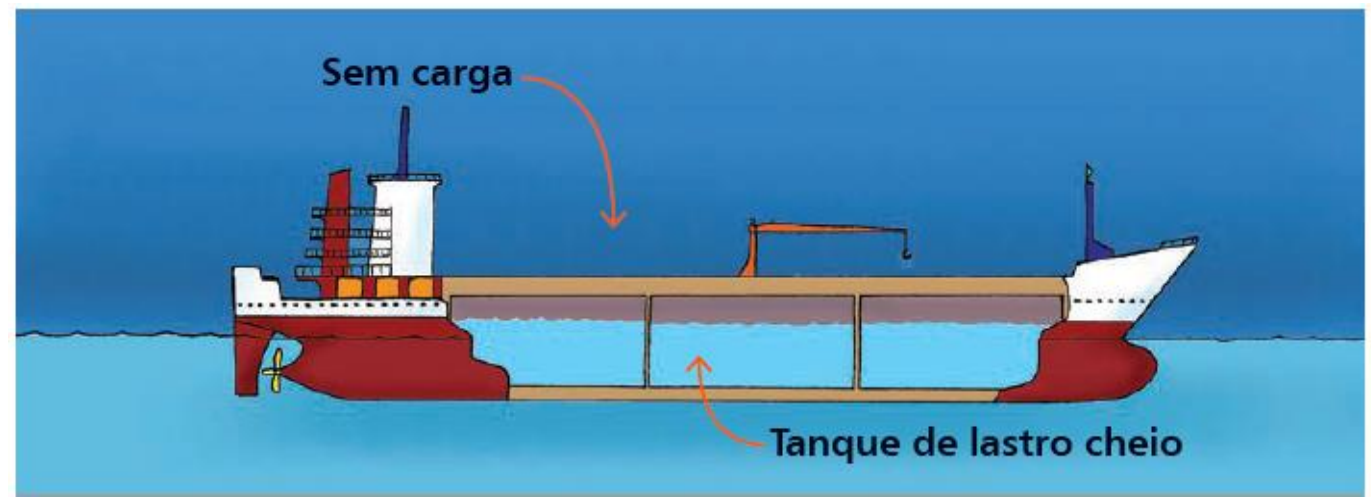

Em rota, sem carga, e cheio de água de lastro.

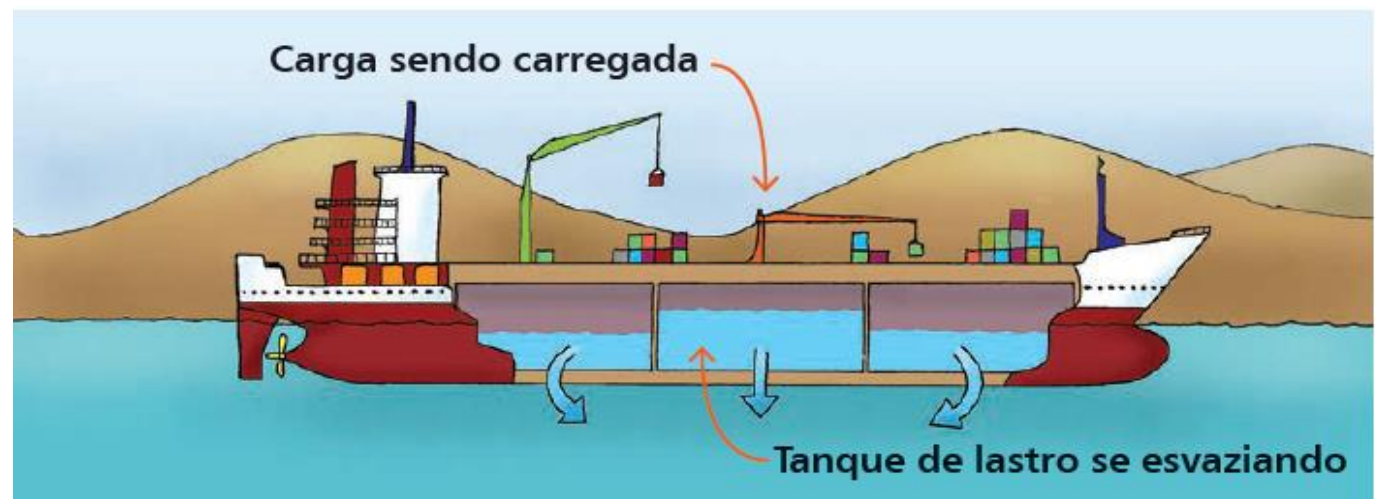

No porto de destino, recebendo carga e descarregando água de lastro

\footnotetext{
${ }^{9}$ Fonte: Texto e imagens retirados do livro Investigar e aprender: ciências, $4^{\circ}$ ano (CARVALHO et al,
} 2011a) 


\section{ANEXO D - Texto "Vida marinha na água de lastro" para realização da sétima atividade $^{10}$}

\section{VIDA MARINHA NA ÁGUA DE LASTRO}

Uma embarcação de grande porte pode atravessar os mares indo, por exemplo, do Brasil à China, carregando mercadorias e pessoas e parando em diversos portos ao redor do mundo.

Em cada um desses portos, sua carga pode se alterar: podem sair e entrar passageiros, entrar carga e sair água dos tanques de lastro, e pode também sair carga e entrar água nos tanques.

Cada vez que a água de lastro é colocada em uma embarcação, seres vivos que vivem nas águas onde ela está ancorada (algas, bactérias, protozoários, plantas e animais), pequenos o suficiente para serem sugados pelas bombas, são transportados para dentro dos tanques.

Alguns desses seres vivos podem morrer no próprio tanque de lastro devido às condições internas pouco favoráveis à sua sobrevivência, mas alguns conseguem sobreviver a longas viagens.

Quando a embarcação para em um porto e seus tanques são esvaziados, tais seres vivos são despejados na água de um local diferente do que habitavam originalmente e onde talvez não existissem animais de sua espécie até então.

Após despejados no mar, muitos desses pequenos seres vivos morrem, pois, na maior parte das vezes, não encontram alimento e condições climáticas adequadas para a sua sobrevivência.

Alguns conseguem sobreviver, mas não encontram parceiros para se reproduzir, o que acaba impedindo que a espécie desse ser vivo ocupe o novo ambiente em que foi despejado.

Apesar de muitos indivíduos não encontrarem as condições ideais para sobreviver, há aqueles que chegam a locais que possuem boas condições climáticas, bastante alimento e sem predador. O que acontecerá com eles nessas condições?

\footnotetext{
${ }^{10}$ Fonte: Texto retirado do livro Investigar e aprender: ciências, $4^{\circ}$ ano (CARVALHO et al, 2011a)
} 
ANEXO E - Modelo de tabela para registro e análise do jogo "Presa e predador" para realização da nona atividade ${ }^{11}$

Enquanto brincamos de presa e predador, a professora registrou as situações para cada grupo de seres vivos em cada uma das rodadas em uma tabela como esta, onde podemos ver a quantidade de plantas, tapitis e jaguatiricas de cada rodada:

\begin{tabular}{|c|l|l|l|}
\hline Rodada & Plantas & Tapitis & Jaguatiricas \\
\hline $1^{\mathrm{a}}$ & & & \\
\hline $2^{\mathrm{a}}$ & & & \\
\hline $3^{\mathrm{a}}$ & & & \\
\hline $4^{\mathrm{a}}$ & & & \\
\hline $5^{\mathrm{a}}$ & & & \\
\hline $6^{\mathrm{a}}$ & & & \\
\hline $7^{\mathrm{a}}$ & & & \\
\hline
\end{tabular}

${ }^{11}$ Fonte: Texto retirado do livro Investigar e aprender: ciências, $4^{\circ}$ ano (CARVALHO et al, 2011a) 


\section{ANEXO F - Questões recebidas pelos estudantes para realização da nona atividade ${ }^{12}$}

Agora com seus colegas discuta e responda as questões abaixo e depois escreva e desenhe sobre suas conclusões.

1) Em que rodada o número de plantas foi maior?

2) Em que rodada o número de plantas foi menor?

3) Qual rodada começou com o maior número de tapitis? Quantas plantas havia no final desta rodada?

4) Qual rodada começou com o menor número de tapitis? Quantas plantas havia no final desta rodada?

5) À medida que o número de tapitis aumenta, o número de plantas aumenta ou diminui? Explique por que isso acontece.

6) Além da quantidade de alimento, que outro fator influenciou no tamanho da população dos tapitis?

7) Houve variações no tamanho da população de jaguatiricas? Quando o número de jaguatiricas era baixo, na rodada seguinte a população de tapitis aumentava ou diminuía? O que acontecia com as plantas em seguida? Explique esses resultados.

8) Em quais rodadas o número de jaguatiricas foi maior? Relacione esse acontecimento ao crescimento das populações de tapitis e de plantas.

\footnotetext{
${ }^{12}$ Fonte: Texto retirado do livro Investigar e aprender: ciências, $4^{\circ}$ ano (CARVALHO et al, 2011a)
} 


\section{ANEXO G - Texto "Entendendo o jogo presa e predador" para realização da nona atividade $^{13}$}

\section{ENTENDENDO O JOGO "PRESA E PREDADOR”}

Agora que já brincamos de "Presa e Predador" e que já conversamos sobre esta brincadeira, vamos tentar entender um pouco mais sobre o que aconteceu na nossa representação?

Durante o jogo, em cada uma das etapas, as plantas permaneciam em seus lugares e os tapitis tentavam se alimentar delas. Os tapitis precisavam ser espertos, pois, em nossa "mata", além das plantas e de seus colegas tapitis, havia também velozes e ferozes jaguatiricas que desejavam também se alimentar e sua presa eram os tapitis!

Ao término de uma rodada, tapiti que conseguisse se alimentar continuava tapiti na rodada seguinte. A planta da qual ele havia se alimentado também voltava na próxima rodada como tapiti. O mesmo acontecia no caso da jaguatirica: se ela se alimentasse, na rodada seguinte continuaria a ser jaguatirica. Sua presa, ou seja, o tapiti do qual havia se alimentado, também seria jaguatirica na rodada seguinte.

E o que acontecia aos tapitis e jaguatiricas que não conseguissem se alimentar em uma rodada? Na rodada seguinte voltavam à brincadeira como planta!

Isso acontecia porque os animais que não conseguem alimento morrem de fome. Seus corpos são, então, transformados em nutrientes que as plantas utilizam para viver e, por este motivo, na rodada seguinte, apareciam como plantas.

Os tapitis e jaguatiricas que conseguiram alimento continuavam, na rodada seguinte, respectivamente, como tapitis e jaguatiricas porque haviam conseguido alimento e, assim, sobreviveram.

Todos os seres vivos precisam de alimento para que se mantenham saudáveis e se reproduzam, garantindo novos indivíduos para a geração seguinte e é por este motivo que as plantas e os tapitis que fossem capturados por seu predador voltavam na rodada seguinte como um ser vivo da mesma espécie de seu predador. Ou seja, as plantas que foram capturadas voltam como tapitis; os tapitis capturados voltavam como jaguatiricas. Isso

\footnotetext{
${ }^{13}$ Fonte: Texto retirado do livro Investigar e aprender: ciências, $4^{\circ}$ ano (CARVALHO et al, 2011a)
} 
acontecia porque quando um ser vivo serve de alimento para outro, as substâncias que formam seu corpo passam a fazer parte desse outro ser que o devorou. 